FERNANDA CAROLINA DE ARAUJO IFANGER

A INTOLERÂNCIA AO DIFERENTE: O PROBLEMA DO BULLYING ESCOLAR

TESE DE DOUTORADO

ORIENTADOR: PROF. SÉRGIO SALOMÃO SHECAIRA

FACULDADE DE DIREITO DA UNIVERSIDADE DE SÃO PAULO

SÃO PAULO

2014 


\section{A INTOLERÂNCIA AO DIFERENTE: O PROBLEMA DO BULLYING ESCOLAR}

Tese apresentada à Faculdade de Direito da Universidade de São Paulo como requisito parcial para a obtenção do título de Doutora em Direito (área de concentração Direito Penal, Medicina Forense e Criminologia), sob a orientação do Professor Titular Sérgio Salomão Shecaira.

FACULDADE DE DIREITO DA UNIVERSIDADE DE SÃO PAULO

SÃO PAULO 


\section{A INTOLERÂNCIA AO DIFERENTE: O PROBLEMA DO BULLYING ESCOLAR}

Tese apresentada à Faculdade de Direito da Universidade de São Paulo como requisito parcial para a obtenção do título de Doutora em Direito (área de concentração Direito Penal, Medicina Forense e Criminologia), sob a orientação do Professor Titular Sérgio Salomão Shecaira.

Aprovado em

BANCA EXAMINADORA 
Aos meus pais FERnANDO $e$ VERA e ao meu irmão FERnANDO, amores que a vida escolheu para mim.

Ao meu marido RoGÉRIO, amor que escolhi para a vida. 


\section{AGRADECIMENTOS}

Mais uma vez, chego ao fim de uma etapa importante da minha vida, contando com o apoio de muitos.

Por isso, não posso deixar de agradecer-lhes, manifestando, nestas breves palavras, a importância que tiveram para mim.

Agradeço ao professor SÉRGIO SALOMÃO SHECAIRA, meu querido orientador na academia e na vida, a quem dedico todo o meu respeito, admiração e carinho e de quem espero sempre ser discípula.

Aos professores da Faculdade de Direito, da Faculdade de Psicologia, da Faculdade de Educação e da Faculdade de Filosofia, Letras e Ciências Humanas, todas da Universidade de São Paulo, locais onde cursei matérias durante o Doutorado, especialmente aos que compuseram minha banca de qualificação, professor ALVINO AUGUSTO DE SÁ, professora ANA ELISA LIBERATORE BECHARA e professor MARCOS CÉSAR ALVAREZ, os quais trouxeram contribuições fundamentais para a consecução do presente trabalho.

A todos os meus companheiros de docência na Pontifícia Universidade Católica de Campinas, que com indicações bibliográficas ou palavras de incentivo colaboraram sobremaneira na execução da minha tese, especialmente a professora e amiga ANA ELISA SPAOLONZI QUEIROZ ASSIS, que carinhosamente leu meus escritos e fez com que enveredar pelos ensinamentos da Educação se tornasse uma tarefa menos tortuosa.

Aos meus amigos que de perto ou de longe me fazem entender o que a verdadeira amizade significa.

Aos meus alunos que a cada dia comprovam a dialética que pressupõe a tarefa de ensinar e com os quais tenho aprendido grandes lições.

Aos funcionários do IBCCrim e das bibliotecas da Faculdade de Direito e da Faculdade de Educação, por seu tratamento acolhedor e respeitoso. 
Temos o direito a ser iguais quando a nossa diferença nos inferioriza; e temos o direito a ser diferentes quando a nossa igualdade nos descaracteriza. Daí a necessidade de uma igualdade que reconheça as diferenças e de uma diferença que não produza, alimente ou reproduza as desigualdades. 


\section{RESUMO}

A presente tese ocupa-se do estudo do bullying escolar, partindo da constatação de que sua ocorrência se deve à intolerância diante da diferença que o outro representa. Para alcançar tal objetivo foi necessário unir os ensinamentos da Criminologia e da Educação, visando a desvendar os processos sociais que estruturam o espaço escolar. O caminho percorrido inicia-se pela análise da violência, passando pela violência escolar, para finalmente encontrar o bullying, considerado mais um dos modos de manifestação do fenômeno. A junção dos ensinamentos emanados das duas ciências mencionadas solidifica-se no momento em que a escola é estudada como instrumento do exercício do controle social informal dos comportamentos.

Palavras-chave: Criminologia; Educação; Violência; Bullying; Escola; Controle Social. 


\begin{abstract}
The present thesis analyzes the study of school bullying, based on the finding that its occurrence is due to intolerance of the differences that others represent. To achieve this objective it was necessary to unite the teachings of Criminology and Education, in order to unravel the social processes that structure the school environment. The road travelled begins with the analysis of violence, continuing through to school violence, finally reaching bullying, considered one of the manifestations of this phenomenon. The union of the teachings stemming from the two aforementioned sciences solidifies the moment that school is studied as a means of exercising informal social control of behavior.
\end{abstract}

Keywords: Criminology; Education; Violence; Bullying; School; Social Control. 


\section{RÉSUMÉ}

Cette thèse s’occupe de l'étude du hercèlement quotidien à l'école, à partir de la constatation de que ce fait parvient en raison de l'intolérance face à la différence que l'autre représente. Afin d'atteindre cet objectif il a été nécessaire d’unir les savoirs de la Criminologie et de l'Education, visant à dévoiler les processus sociaux qui structurent l'espace scolaire. Le chemin parcouru démarre par l’analyse de la violence, passant par la violence scolaire, pour finalement retrouver l' hercelèment quotidien, considéré l'une des formes de la manifestation du phénomène de la violence. La jonction des deux savoirs émanés par les deux sciences se solidifie dans le moment où l'école est étudiée en tant qu'un outil de l'exercice du contrôle social informel des comportements.

Mots-clés: Criminologie, Education, Violence, Hercèlement quotidien, École, Contrôle social. 


\section{SUMÁRIO}

INTRODUÇÃO

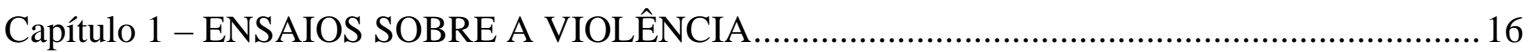

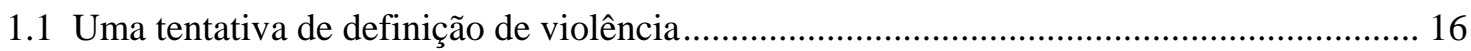

1.1.1 A violência como resposta à intolerância.................................................................. 25

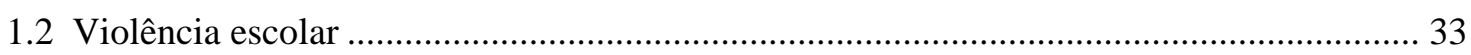

1.2.1 Definições sobre a violência escolar ........................................................................... 38

1.2.2 Transgressão, incivilidade e violência escolar ............................................................. 43

1.2.3 Explicações para a violência escolar ...................................................................... 47

Capítulo 2 - CONSIDERAÇÕES TEÓRICAS SOBRE O BULLYING ESCOLAR..........................62

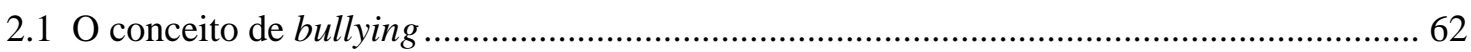



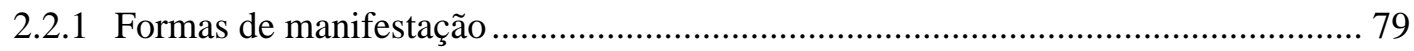

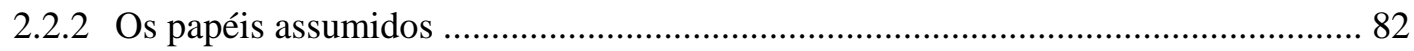

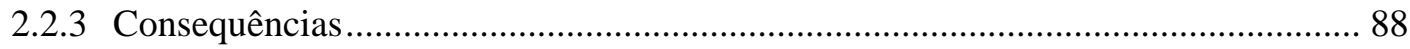

2.2.4 A diferença que desencadeia o bullying escolar ........................................................ 94

2.3 O papel do estigma e do rótulo social na interação entre os escolares .............................. 110

Capítulo 3 - A ESCOLA SOB A PERSPECTIVA DA CRIMINOLOGIA CRÍTICA ...................129

3.1 Prevenção e repressão dos comportamentos desviantes: análise do controle social......... 129

3.1.1 Formas de exercício do controle social ................................................................. 147

3.1.1.1 Controle social formal ........................................................................... 150

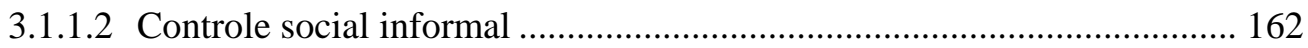

3.2 A escola como instrumento do controle social informal: um diálogo entre a Educação e



3.2.1 Obediência, ordem e disciplina: os mecanismos do controle.................................. 179

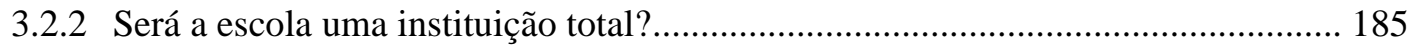

3.3 Uma explicação para a efetividade do controle social informal: a teoria dos vínculos sociais

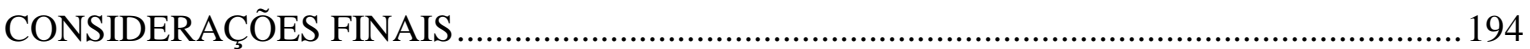

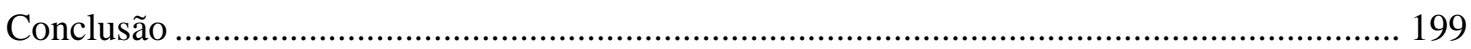

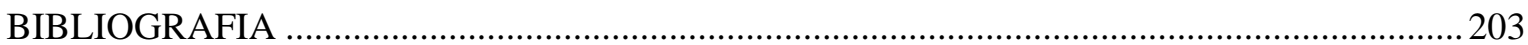




\section{INTRODUÇÃO}

Por meio dos livros de Criminologia é possível compreender que a ciência ocupa-se do estudo do delito, do delinquente, da vítima e do controle social.

Está certo. No entanto, é preciso entender o que está por trás dessa escolha, o que existe em comum entre esses referenciais.

Após uma reflexão chega-se à conclusão de que o que une todos esses elementos é o conflito. Nesse diapasão, em última análise, fica claro que a Criminologia investiga as relações sociais conflitivas.

Não obstante a conduta não ser considerada criminosa em dada sociedade, sendo ela a expressão de um conflito social, deve a Criminologia ocupar-se dela, descobrir suas nuanças, compreender suas especificidades e atuar sobre ela.

Defender que uma ação só deve ser alvo de preocupação após ser alçada à categoria de crime contrapõe-se aos objetivos da Criminologia, uma vez que não interessa a essa ciência a normatização criminal dos comportamentos, já que ela, nos últimos anos, tem trabalhado aguerridamente contra o sistema penal, cuja atuação, em vez de solucionar os problemas sociais, mostra somente apropriar-se e aprofundar a contenda que se propõe resolver.

Vale lembrar que não é a criminalização de um ato que mede sua danosidade. Por conseguinte, não é porque uma conduta não tenha ainda se tornado criminosa que ela não produzirá consequências negativas sobre os envolvidos.

Sabe-se que a consideração de uma ação como crime responde apenas a interesses de grupos sociais, a jogos de poder, à imposição de pontos de vista e não a uma exigência do próprio comportamento.

Em virtude disso, do mesmo modo que no âmbito macrossocial a Criminologia perquire as razões da violência, deve fazê-lo também no ambiente escolar, já que a escola, a despeito de suas peculiaridades, conforma um sistema social próprio. Ela pressupõe uma 
organização, uma estrutura e atores particulares, envolvidos em uma relação específica, que devem ser compreendidos naquilo que os distingue do restante do corpo social.

É nesse contexto, então, que se apresentam ao criminólogo a necessidade e o desafio de estudar o bullying escolar.

Necessidade por várias razões. Ainda que o bullying não seja um fenômeno novo, contemporaneamente ele tem se feito cada vez mais presente na vida dos escolares, tornando-se fundamental compreender as engrenagens dos sistemas social e escolar que têm permitido, ou até estimulado, essa conduta.

Outrossim, não se pode desconsiderar que a violência escolar não é imprevisível. Ela foi construída socialmente e negar-se a compreender o problema pode colaborar para maximizá-lo.

Importante evidenciar, nesse contexto, que “a juventude é o segmento que mais catalisa as tensões sociais como também as exterioriza, a juventude é a vitrine dos conflitos sociais”. ${ }^{1}$ Desse modo, uma contenda que desabrocha em seu seio não pode ser deixada de lado, sob o risco de penitenciar todo um grupo social e atrapalhar seu desenvolvimento.

Um desafio por outras tantas razões. A violência escolar, mormente a interpares, é um tema ainda muito pouco debatido no Brasil. Na Criminologia, então, os estudos sobre o assunto são raríssimos.

Fato é que os criminólogos evitam aprofundar a investigação das instituições que como a escola conformam o controle social informal em virtude do desconforto e da dificuldade implicados na tarefa de compreender o funcionamento de ambientes desconhecidos em sua profundidade, e por vezes enigmáticos, para o teórico que se ocupa do estudo do fenômeno criminoso.

DIÓGENES, Glória. Grupos identitários e fragmentação social: a violência como "marca". In: SANTOS, José Vicente Tavares dos (Org.). Violência em tempo de globalização. São Paulo: Hucitec, 1999. p. 165. 
Em consonância com essa ideia afirma Castro que, “como criminólogos, com uma formação mais ou menos específica, embora, em todo caso, pouco ortodoxa, a incursão no campo da educação foi limitante”. ${ }^{2}$

Em decorrência da mencionada falta de estudos acerca do tema, depara-se, ao realizar uma pesquisa dessa natureza, com a “pouca quantidade de textos criminológicos que tratem com certa profundidade as instâncias informais de controle social e que abram mão de repetir fórmulas vazias de conteúdo científico" ${ }^{3}$ Por conta disso, não se questiona e não se problematiza a escola como estrutura de imposição ideológica e de discriminação cultural, fazendo parecer que ela tenha sido neutra na realização dessa tarefa. ${ }^{4}$

Por todo o exposto, é que a mencionada lacuna precisa ser suprida. Para tanto, mister que a Criminologia e a Educação se unam na troca e na complementação de seus saberes.

É preciso romper as fronteiras entre as disciplinas, as quais levam a crer que a realidade social é tão compartimentalizada que é possível compreendê-la por completo utilizando-se apenas de um viés segmentado de conhecimento. O que se percebe é que “esse modo de justificar as fronteiras entre disciplinas torna-se problemático, pois assumimos que o mundo humano reflete divisões tão precisas que demandam ramos especializados de especialização". ${ }^{5}$

Parece mesmo que esse desafio já nasceu com a Criminologia que, por sua interdisciplinaridade, muitas vezes foi acusada de não ser ciência. Assim, “a violação das

CASTRO, Lola Aniyar de. Criminologia da libertação. Tradução de Sylvia Moretzsohn. Rio de Janeiro: Revan, 2005. p. 167.

3 BARREIRAS, Mariana Barros. Controle social informal x controle social formal. In: SÁ, Alvino Augusto de; SHECAIRA, Sérgio Salomão. Criminologia e os problemas da atualidade. São Paulo: Atlas, 2008. p. 300.

4 CERLETTI, Alejandro. El concepto de igualdad en las políticas educativas: una aproximación filosófico-política. In: TREVISAN, Amarildo Luiz; TOMAZETTI, Elisete Medianeira; ROSSATTO, Noeli Dutra (Orgs.). Diferença, cultura e educação. Porto Alegre: Sulina, 2010.

5 BAUMAN, Zygmunt; MAY, Tim. Aprendendo a pensar com a Sociologia. Tradução de Alexandre Werneck. Rio de Janeiro: Zahar, 2010. p. 14. 
fronteiras de outras disciplinas é recorrente no criminólogo, dando por certo que ao fazer criminologia cada um é relativamente livre para traçar os limites”. 6

Para alcançar, portanto, o objetivo de desvendar as relações que permeiam a escola e, consequentemente, compreender o bullying escolar, a presente tese foi dividida em três Capítulos.

No primeiro Capítulo apresenta-se uma incursão sobre a violência, visando a elucidar as suas diversas vertentes de análise, demonstrando-se ainda que nas sociedades contemporâneas ela pode ser interpretada como manifestação do comportamento intolerante, para depois debruçar-se especificamente sobre a violência escolar.

Logo, pretende-se evidenciar que a despeito de o presente trabalho objetivar analisar a violência interpares, existem outras violências que se apresentam na escola, como a que envolve os alunos e os professores e os alunos e o corpo diretivo do estabelecimento, as quais encontram também inúmeras maneiras de expressão.

Ademais, para que o fenômeno possa ser compreendido em sua inteireza, apresentam-se também nesse Capítulo outros comportamentos que com ele se confundem, como a transgressão e a incivilidade.

No segundo Capítulo o estudo foca-se no bullying escolar, o qual se considera uma das representações da violência escolar.

Exibem-se aí a definição do problema, os comportamentos pelos quais ele se manifesta, as características dos envolvidos, bem como as consequências derivadas de sua ocorrência no âmbito escolar, visando a desmistificar a ideia de que todo ato agressivo perpetrado contra um estudante configura o bullying.

Outrossim, ofertar-se-á uma explicação para o fenômeno com base na constatação de que o fundamento do bullying escolar é o repúdio em relação a alguma

6 PAVARINI, Masimo. Como resistir: control social y saber critico. Capítulo Criminológico, Maracaibo, n. 22, p. 33-53, 1994, especialmente p. 44. 
característica considerada estranha, fora dos padrões do alunado. Considera-se, pois, que o bullying é motivado, no âmbito escolar, pela intolerância ao diferente.

Como parte dessa explicação demonstra-se, no final do excerto, a influência que o rótulo e o estigma têm sobre as agressões perpetradas contra os estudantes.

Por fim, no terceiro Capítulo é que as lições da Criminologia e da Educação se integrarão completamente no estudo das maneiras pelas quais a sociedade realiza a prevenção e a repressão dos comportamentos de seus pares.

Em outras palavras, apresenta-se a evolução na construção do controle social e as vertentes que se desdobram em seu exercício: o controle social formal e o controle social informal.

Com o objetivo de contrapor e cotejar as duas maneiras de controle mencionadas, primeiramente analisa-se o controle social formal e, em seguida, o controle social informal, do qual a escola faz parte, fornecendo-se explicações criminológicas para o seu desempenho.

Almejando a consecução dos objetivos propostos na presente tese, investiga-se a escola em um item separado. Perquirem-se, nessa teorização, os reais propósitos do controle por ela realizado, os mecanismos pelos quais ele se efetiva, respondendo ainda à questão de se a instituição escolar é uma instituição total. 


\section{Capítulo 1}

\section{ENSAIOS SOBRE A VIOLÊNCIA}

\subsection{Uma tentativa de definição de violência}

O termo violência é polissêmico, sendo assim, refere diversas condutas, mais ou menos semelhantes, dirigidas contra algo ou alguém.

Ademais, o vocábulo é de interesse para diversas áreas do saber, sendo que cada uma acaba tentando interpretar seu sentido mediante um conjunto de conhecimentos próprios, o que pode deixar sua identificação confusa, conforme se verá no presente excerto.

Muitas vezes, o que é possível fazer para compreendê-lo é agrupar seus entendimentos com base em características comuns e distintivas, aplicando-as a análise proposta.

Logo, no presente trabalho, ao definir-se violência, utilizar-se-ão, precipuamente, os referenciais teóricos da Criminologia de cunho sociológico e da Educação, matérias sobre as quais se funda esta tese. São os autores que escrevem - direta ou indiretamente - sobre essas áreas que oferecerão o suporte para a compreensão do fenômeno, uma vez que o estudo da violência reclama a interdisciplinaridade.

Fato é que uma pesquisa zetética sob esses enfoques visa à efetivação de um novo olhar sobre o problema da violência, mormente a escolar, partindo-se da ideia de que os pressupostos ora existentes devem ser questionados e revistos, possibilitando uma nova mirada sobre a questão.

Para Castro, “violência é a modificação ao que existe. É uma forma de criar desordem na ordem natural das coisas. Exerce-se a violência cada vez que se faz alguma 
coisa e cada vez que não se faz algo que deveria ser feito. É uma espécie de círculo vicioso".

Michaud, por sua vez, defende que a qualificação de uma ação como violenta depende das normas vigentes e por isso o conceito não consegue ser delimitado e é absolutamente mutável: alterada uma norma de referência, a violência passa a existir ou se extingue.

Logo, revela o autor que a abordagem da violência não pode ser objetiva, e sim dependente dos critérios escolhidos e dos pontos de vista de seu definidor, que podem ser institucionais, jurídicos, sociais e até mesmo pessoais.

Assim, ao apresentar sua teorização sobre o conceito Michaud defende que

na ideia que fazemos dela, entram, com efeitos, o caos, a conflagração e a transgressão da ordem. [...] A violência é portanto assimilada ao imprevisível, à ausência de forma, ao desregramento absoluto. Não é de espantar se não podemos defini-la. [...] Como definir o que não tem nem regularidade nem estabilidade, um estado inconcebível no qual, a todo momento, tudo (ou qualquer coisa) pode acontecer? Como transgressão das regras e das normas, a "violência” deixa entrever a ameaça do imprevisível. Num mundo estável e regular, ela introduz o desregramento e o caos. A palavra "violência” é então como a denominação de uma situação de caos absoluto, comparável ao estado de natureza de Hobbes, onde reina a guerra de todos contra todos.$^{8}$

Também evidenciando a complexidade da definição do termo, Lucinda, Nascimento e Candau asseveram que “a marca constitutiva da violência seria a tendência à destruição do outro, podendo a ação situar-se no plano físico, psicológico ou ético”. 9

A destruição também é elemento da violência para Costa. O autor assevera que a violência refere-se à satisfação dos impulsos e desejos destrutivos do homem, sendo que

7 CASTRO, Lola Aniyar de. Criminologia da libertação. Tradução de Sylvia Moretzsohn. Rio de Janeiro: Revan, 2005. p. 246.

8 MICHAUD, Yves. A violência. Tradução de L. Garcia. São Paulo: Ática, 1989. p. 12-13.

9 LUCINDA, Maria da Consolação; NASCIMENTO, Maria das Graças; CANDAU, Vera Maria. Escola e violência. 2. ed. Rio de Janeiro: DP\&A, 2001. p. 20. 
as motivações nobres ou vis do ato violento nada mais são do que sua racionalização, uma tentativa de justificar a ação realizada. ${ }^{10}$

Note-se que nas ideias acima expostas, os autores destacam o espectro negativo que o termo tem. É a violência tratada como conduta contraposta à paz.

Entretanto, conforme assevera Michaud, aspectos positivos e negativos podem a ela estar relacionados. Assim,

por estar estreitamente ligada à ideia de transgressão das regras, a de violência está carregada de valores positivos ou negativos vinculados à ideia de transgressão. Através dela agita-se uma ameaça ou denuncia-se um perigo. Nos anos 60, a violência liberadora foi celebrada, como o era por G. Sorel no início do século, porque ela representava a ruptura com as regras de uma sociedade condenada. Em contrapartida, as denúncias do aumento da violência e da segurança hoje tendem a assimilar qualquer desordem com uma violência que ameaça a ordem social no seu todo. ${ }^{11}$

Desse modo, evidencia-se que não necessariamente, nem sempre, o ato violento é contraproducente, indesejável ou inaceitável. ${ }^{12}$

O Estado utiliza-se de violência para manter a coesão social. Suas instituições, ao demandarem a ordem na sociedade, valem-se de mecanismos violentos, capazes de suprimir ou diminuir a liberdade dos cidadãos. Isso é o que faz, por exemplo, o sistema penal. Ele é a violência que se apresenta como resposta à violência.

Nesses termos, as instituições, o direito e o exercício do poder são violências que se exercem contra alguém, mesmo quando sua ação não desperte a crítica de ninguém. ${ }^{13}$

10 COSTA, Jurandir Freire. Violência e psicanálise. 3. ed. São Paulo: Graal, 2003.

11 MICHAUD, Yves. A violência. Tradução de L. Garcia. São Paulo: Ática, 1989. p. 13.

12 Importante asseverar que para Castro, o simples fato de classificar o ato violento como bom ou mau é uma maneira de modificar uma ordem neutra, sendo, portanto, uma forma de violência. Cf. CASTRO, Lola Aniyar de. Criminologia da libertação. Tradução de Sylvia Moretzsohn. Rio de Janeiro: Revan, 2005.

13 CASTRO, Lola Aniyar de. Criminologia da libertação. Tradução de Sylvia Moretzsohn. Rio de Janeiro: Revan, 2005. 


\section{Ademais, quando exercida}

contra o indivíduo violento que, por exemplo, mata, estupra, pode ser vista por muitos sujeitos, em geral pacíficos, como indispensável para a ordem social. A violência rebelde pode ser admirada por muitos. A violência tem um papel e um significado próprio em cada situação social. $^{14}$

Diante disso, destacando a relação entre violência e moral, La Talle ressalta que

seria um grave erro pensar que todo sistema moral (se é que se pode falar em sistema em se tratando de moral) condena indiscriminadamente a violência. Com efeito, alguns sistemas de valores morais podem até incentivá-la. É o que se vê, por exemplo, nas chamadas "guerras santas", nas quais, em nome do Bem, ordena-se o aniquilamento de pessoas estranhas a determinada fé. É o que se vê também no apoio de alguns à pena de morte. Logo, nem toda moral é doce e pacífica. Todavia, não há moral que não se debruce sobre o tema da violência. Todas elas têm o mandamento "não matarás", imperativo necessário à sobrevivência da comunidade. Algumas morais dirão que não se deve matar nunca (a moral budista, por exemplo). Outras tornarão relativo este mandamento (podes matar o inimigo, o culpado, o traidor etc.). Mas o fato é que o tema da violência (sobretudo física) sempre é alvo de uma normatização moral. Sempre haverá um "não" que a limita de alguma maneira. Portanto, é válido pensar que a "natureza" violenta do ser humano será objeto da educação moral das crianças. ${ }^{15}$

Em vista de toda a multiplicidade do termo, então, Schilling defende que, ao trabalhar com violência, seja na escola, na rua ou na família, deve-se ter em conta a insuficiência das teorias formuladas sobre o assunto, devendo elas ser vistas como inacabadas, inconclusivas e precárias. Assim, relata a autora que “as palavras são fracas.

14 LATERMAN, Ilana. Violência e incivilidade na escola: nem vítimas, nem culpados. Florianópolis: Letras Contemporâneas, 2000. p. 26.

15 LA TALLE, Yves. Glória e violência: reflexão sobre a influência da televisão na construção da personalidade moral. In: PACHECO, Elza Dias (Org.). O cotidiano infantil violento: marginalidade e exclusão social. São Paulo: Lapic: L’Editora: Fapesp, 2007. p. 155. 
Resta sempre uma perplexidade, uma sensação de estranhamento, a certeza de que nossos esquemas explicativos são insuficientes”. ${ }^{16}$

Nesse diapasão Martinez defende que a violência deve ser considerada um metaconceito que atenda a uma teoria capaz de entender sua complexidade e suas variações. ${ }^{17}$

A despeito da dificuldade na determinação do que é e do que não é violento, a autora alerta que se deve atentar para as concepções relativistas e subjetivistas sobre o tema que, defendendo a ideia da fluidez do conceito, acabam colaborando para o seu desconhecimento, uma vez que “o desconhecimento e a negação da violência são seus melhores suportes". ${ }^{18}$

Para ela é insuficiente apenas entender subjetivamente a violência, sendo certo que ela deve ser compreendida no bojo da relação na qual se manifesta. ${ }^{19}$

Fato é que o ato de violência não conta com uma etiqueta de identificação, que permita a fácil adaptação da conduta praticada ao conceito enunciado. Porém, “não se trata de não ser possível definir violência, mas de se levar em conta que não há uma definição universal, pois não é possível encontrar-se uma visão sistemática do fenômeno, que possibilite isolar suas formas mais empíricas ou contingentes”, ${ }^{20}$

Nesse diapasão, defende Debarbieux que

é um erro fundamental, idealista e histórico crer que definir a violência, ou qualquer outro termo, por sinal, seja uma questão de se aproximar o máximo possível de um conceito absoluto de violência, de uma “ideia” de

16 SCHILLING, Flávia. Violência na escola. In: WESTPHAL, Márcia Faria; BYDLOWSKI, Cynthia Rachid (Ed.). Violência e juventude. São Paulo: Hucitec, 2010. p. 221.

17 MARTINEZ, Marie-Louise. Comprendre la violence une et multiforme. In: MARTINEZ, Marie-Louise; SEKNAADJÉ-ASKÉNAZI, José (Orgs.). Violence et éducation: de La méconnaissance à l'action éclairée. 2. ed. Paris: L’Harmattan, 2002.

18 Idem, ibidem, p. 8.

19 Idem, ibidem.

20 MAREUSE, Márcia Aparecida Giuzi. Reflexões sobre a violência: manifestações na mídia e implicações no universo infantojuvenil. In: PACHECO, Elza Dias (Org.). O cotidiano infantil violento: marginalidade e exclusão social. São Paulo: Lapic: L’Editora: Fapesp, 2007. p. 47. 
violência que faz com que a palavra e a coisa estejam para sempre adequadas. $^{21}$

Ainda em sua opinião, os estudiosos do tema não deveriam estar pesquisando a violência como se ela fosse um todo indivisível, e sim multiplicar os pontos de vista sobre ela, explicar suas definições e suas escolhas, e demonstrar como seus resultados tornam mais compreensível essa realidade. ${ }^{22}$

Importante perceber, de todo modo, que a violência é um fenômeno social que, portanto, envolve percepções e representações do que cada sociedade e cada indivíduo considera um ato violento. Nesse diapasão, "há disputas na sociedade sobre quais são as práticas consideradas como violentas, ou seja, quais são as práticas que são intoleráveis, nas relações humanas”. 23

Assim, assevera Engelke que

mesmo a manifestação individual da violência é, em alguma medida, social, com determinantes estruturais. Um exemplo comum: nos EUA é comum o crime em que jovens armados entrem em universidades e escolas, fuzilam dezenas de pessoas e depois se matam. Isso não é tão frequente em outros países. Mas os americanos não nasceram com essa inclinação de matar pessoas nos campi universitários e depois se matar. Há fatores estruturais agindo ali para que esse crime aconteça com mais frequência nos EUA do que em outros lugares. A manifestação da violência sempre tem influência de fatores estruturais e sociais. ${ }^{24}$

Em consonância com esse pensamento defende Mareuse que

21 DEBARBIEUX, Éric. "Violência nas escolas": divergências sobre palavras e um desafio político. In: DEBARBIEUX, Éric; BLAYA, Catherine (Orgs.). Violência nas escolas e políticas públicas. Tradução de Patrícia Zimbres. Brasília: UNESCO, 2002. p. 64.

$22 \quad$ Idem, ibidem, p. 65.

23 SCHILLING, Flávia. Violência na escola. In: WESTPHAL, Márcia Faria; BYDLOWSKI, Cynthia Rachid (Ed.). Violência e juventude. São Paulo: Hucitec, 2010. p. 223.

24 ENGELKE, Antonio. Quando os valores celebrados apontam no sentido de um individualismo extremado, então é certo que teremos um esgarçamento das relações sociais. Criança e consumo entrevistas - violência. Instituto Alana - Projeto Criança e Consumo: Coordenação editorial 2PRÓ Comunicação, 2011. p. 42-51, especialmente p. 48. 
o movimento no sentido de buscar uma racionalização da violência deve ser compreendido em toda a sua ambiguidade, o que nos faz reconhecer que a violência não se caracteriza por um ato ou fato, mas que possui diferentes interfaces. Em diferentes sociedades ou em diferentes momentos ela recebe valorizações diferentes, sendo tolerada, proibida, encorajada ou passando desapercebida, e sua definição está principalmente atrelada a esse âmbito de análise, uma vez que essas interfaces são construídas através de representações e que essas envolvem diferentes momentos, lugares, pessoas. ${ }^{25}$

Por essa razão é que não se pode confirmar, indene de dúvidas, se existe um aumento da violência nos dias atuais, fator tido como certo para parte da população ocidental. Para se chegar a essa conclusão é necessário compreender o que outrora era tido como reprovável, o que hoje o é, e cotejar essas informações cientificamente, tarefa bastante complexa de ser executada, já que pode não haver correspondência entre os atos violentos nos dois momentos considerados.

No caso do Brasil, à guisa de exemplo, a violência na pós-democratização aparece vinculada à generalização de um individualismo de massa, conforme análise de Peralva. Logo, defende que quanto maior for a vinculação entre os interesses individual e coletivo, menores as chances de exsurgir a violência extrema.

Assim, revela a autora que

há valores mínimos que uma sociedade necessita compartilhar: os da cooperação, do reconhecimento do outro e do direito à vida. A generalização da violência ocorre quando esse mínimo não é compartilhado. Para evitar isso, a democracia precisa garantir um equilíbrio sempre instável entre a igualdade, a liberdade e a referência a uma lei comum. Esse equilíbrio é uma construção histórica que, no caso brasileiro, por enquanto, inexiste. ${ }^{26}$

25 MAREUSE, Márcia Aparecida Giuzi. Reflexões sobre a violência: manifestações na mídia e implicações no universo infantojuvenil. In: PACHECO, Elza Dias (Org.). O cotidiano infantil violento: marginalidade e exclusão social. São Paulo: Lapic: L’Editora: Fapesp, 2007. p. 45.

26 PERALVA, Angelina. Violência e democracia: o paradoxo brasileiro. São Paulo: Paz e Terra, 2000. p. 180. Importante mencionar que no Brasil a violência ganha o debate público com o processo de democratização. Cf. SPOSITO, Marília Pontes. A redução da violência escolar como desafio democrático. Revista do ILANUD, São Paulo, n. 23, p. 107-117, 2002. 
No quadro atual da globalização neoliberal a violência se redimensiona, renova-se tanto em sua subjetividade quanto em sua objetividade. Pode, assim, ser analisada como uma representação, como a subjetividade de certos grupos ou do todo social, como também pode ser uma realidade objetiva, no momento em que se constata a carência de atores e de mediações dos sistemas de relações. ${ }^{27}$

O que aparece como certo no contexto da crise da pós-modernidade, como característica da violência hodierna, é a desvalorização do outro, a solidificação de uma cultura de coisificação das pessoas. Diante disso, esse outro passa a não mais ser visto como um semelhante, e sim como um estranho, o que fomenta sentimentos de indiferença e intolerância em relação a ele. ${ }^{28}$

Não há como olvidar, portanto, da polissemia do conceito, de suas diversas compreensões e sua estreita ligação com o sistema de valores sociais.

Ainda, vinculada à dificuldade de se estabelecer um conceito unívoco de violência, está a multiplicidade de tipologias de violências que podem ser identificadas. Pode-se perceber a existência de manifestações diversificadas do comportamento violento, sendo que há discrepâncias também acerca de quantas e quais as maneiras de apresentação do fenômeno que podem ser identificadas.

A despeito de suas pluralidades, quase todas as teorizações acerca da violência mencionam seus viés físico, de agressão corporal ao outro, e, nesse sentido, essa faceta representa uma manifestação não controvertida do fenômeno. Porém, há outro aspecto relacionado a ela mais difícil de ser determinado, que é a violência sutil, mascarada, invisível. $^{29}$

\footnotetext{
27 DORNELLES, João Ricardo. Ofensiva neoliberal, globalização da violência e controle social. Discursos Sediciosos: crime, direito e sociedade, São Paulo, v. 7, n. 12, p. 119-137, 2002.

28 Idem, ibidem, p. 119-137.

29 PAREDES, Eugênia Coelho; SAUL, LÉA Lima; BIANCHI, Kátia Simone da Rosa. Violência: o que têm a dizer alunos e professores da rede pública de ensino cuiabana. Cuiabá: EdUFMT; FAPEMAT, 2006. (Coleção Educação e Psicologia, v. 2).
} 
A esse respeito analisa Morais que "as violências sutis têm logrado passar indiscutidas, exatamente por faltar-lhes o impacto da brutalidade sangrenta".30 Fundamental, pois, que se reconheça que a violência das palavras ou da exclusão podem ser muito mais deletérias do que o ato físico.

Nesse sentido, ela é também a negação do diálogo como modo de resolução dos conflitos. É o não ouvir, o não falar, o estigmatizar. É a intencionalidade dirigida ao não conversar, ao não transigir. Para Barretto “a porta de entrada da violência na cultura, e em consequência na educação, foi a negação do diálogo como fonte de conhecimento e entendimento entre os homens”. ${ }^{31}$

Fato é que outrora ela era compreendida pela representação da barbárie. Hodiernamente, contudo, suas manifestações sofisticaram-se. O gesto, os atos e as palavras podem ser violentos e ferir com mais gravidade - simbólica - que a lesão física.

Importante elucidar, de todo modo, que independentemente de como se apresente, a violência é racional, sendo certo que é a lógica existente no ato violento que o diferencia da agressividade.

Nesse diapasão, concorda Morais que a “agressividade é algo resultante da memória biológica, de instintos propriamente animais. Já o conceito de violência implica intencionalidade, o que exige inteligência; razão pela qual os irracionais não são violentos, mas ferozes". ${ }^{32}$

Por ser necessariamente racional é que a violência tem natureza humana. Independentemente de o ato violento ser racional ou inconsciente, voluntário ou involuntário, ele representa sempre o emprego desejado da agressividade. ${ }^{33}$

\footnotetext{
30 MORAIS, Regis de. Violência e educação. Campinas: Papirus, 1995. p. 55.

31 BARRETTO, Vicente. Educação e violência: reflexões preliminares. In: ZALUAR, Alba (Org.). Violência e educação. São Paulo: Cortez, 1992. p. 61.

32 MORAIS, Regis de. Violência e educação. Campinas: Papirus, 1995. p. 20.

33 COSTA, Jurandir Freire. Violência e psicanálise. 3. ed. São Paulo: Graal, 2003.
} 
Diante de todo exposto nesse excerto, evidente a problematização que o conceito engendra. Contemporaneamente, contudo, um aspecto importante de sua compreensão relaciona-se à sua identificação com a ideia de intolerância.

Trata-se, pois, da violência encarada como reflexo da intolerância.

\subsubsection{A violência como resposta à intolerância}

A tolerância é pressuposto das sociedades pós-modernas. Sua falta, ou seja, a intolerância, em contrapartida, tem se mostrado elemento fundante e justificador da violência.

Assim, nas sociedades plurais, para que diversos grupos consigam manter-se em harmonia, mister sejam eles imbuídos de tolerância, já que apenas por meio dela é possível conviver com a diferença. Nesse diapasão, pode-se constatar que “a história está cheia de assassínios de massa cometidos em nome de uma e única verdade [...]. É difícil ressaltar, porém, um único caso de um ato cruel em nome da pluralidade e da tolerância”. ${ }^{34}$

A ideia de tolerância nasceu no seio das discussões de origem religiosa, no fim do período medieval e início da idade moderna, tendo sido considerada um dos valores supremos do Iluminismo, ao tornar possível a coexistência de crenças e de princípios opostos, deixando de lado a ideia da prevalência de apenas um valor absoluto. ${ }^{35}$

Locke e Voltaire, nesse momento, foram seus grandes expoentes, sendo certo que "os breves argumentos explícitos em Locke, assim como, em seguida, os mais genéricos e utópicos de Voltaire, iniciam uma acalorada reflexão entre a tolerância e a intolerância, as causas e os limites de ambas e sua possível oposição”. ${ }^{36}$

34 BAUMAN, Zygmunt. O mal-estar da pós-modernidade. Tradução de Mauro Gama e Cláudia Martinelli Gama. Rio de Janeiro: Jorge Zahar, 1998. p. 248.

35 GUTIÉRREZ, Carlos B. Tolerancia, despropósito conceptual en nuestros días. In: BORDA, Luis Villar; ROSALES, José María (Ed.). Las razones de la convivencia. Bogotá: Universidad Externado de Colombia, 2007. p. 85-105.

36 ANDREUCCI, Álvaro Gonçalves; MANGRICH, Cláudia Souza. Diálogos da tolerância: desafios e impactos na sociedade moderna. Revista de Direito, Florianópolis, n. 1, p. 67-81, jun.-dez. 2006. p. 71. 
Locke, em sua obra Carta sobre a tolerância, escrita durante seu exílio na Holanda no ano de 1685, estabelece o conceito ao tratar da relação entre Igreja e Estado, especificamente no que se refere aos magistrados, defendendo que é seu pressuposto a separação entre ambos.

A esse respeito pondera o autor que

a tolerância com aqueles que divergem em assunto de religião é tão agradável ao evangelho de Jesus Cristo e à razão genuína da humanidade que parece monstruoso que certos homens sejam cegos a ponto de não perceber, numa luz tão clara, a necessidade e vantagem dela. ${ }^{37}$

Entretanto, Locke sinaliza que essa tolerância pode e deve sofrer limitações. Ilustrando tal assertiva, refere que a Igreja não é obrigada, pelo dever de tolerância, a manter em seu seio aquele que fere reiteradamente as leis da sociedade, podendo excomungá-lo, sem, contudo, lesá-lo em seu corpo ou em sua propriedade. ${ }^{38}$

Voltaire, por sua vez, discutiu o tema tendo por impulso um fato ocorrido à época, o qual o arrefeceu sobremaneira. ${ }^{39}$

Jean Calas era um negociante protestante de Toulouse que foi acusado de matar seu próprio filho motivado pela intolerância religiosa, pelo fato de a vítima ter se convertido ao catolicismo. Condenado, Jean Calas foi supliciado na roda enquanto alegava inocência e teve seu corpo lançado ao fogo.

Mais tarde descobriu-se que o executado a todo tempo havia dito a verdade, pois não era o autor do feito, era inocente.

37 LOCKE, John. Carta sobre a tolerância. Tradução de Ari Ricardo Tank Brito. São Paulo: Hedra, 2007. p. 37.

38 Idem, ibidem, p. 37. Nesse sentido também menciona Bobbio que a tolerância, mesmo que compreendida positivamente, pode sofrer uma única limitação, exposta pelo autor nos seguintes termos: "todas as ideias devem ser toleradas, menos aquelas que negam a ideia mesma de tolerância" (Cf. BOBBIO, Norberto. Elogio da serenidade e outros escritos morais. Tradução de Marco Aurélio Nogueira. São Paulo: Unesp, 2002. p. 153).

39 VOLTAIRE. Tratado sobre a intolerância: a propósito da morte de Jean Calas. Tradução de Paulo Neves. 2. ed. São Paulo: Martins Fontes, 2000. 
Nesse contexto, então, é que Voltaire passa a discutir a tolerância com base em sua falta, em sua oposição, a partir da ideia de intolerância.

A respeito do tema assevera que "a natureza diz a todos os homens: fiz todos vós nasceres fracos e ignorantes, para vegetarem alguns minutos na terra e adubarem-se com vossos cadáveres. Já que sois fraco, auxiliai-vos; já que sois ignorantes, instruí-vos e tolerai-vos". 40

Mais tarde, a noção transmudou-se também para o terreno das discussões políticas e após a Segunda Guerra Mundial, em virtude das barbáries praticadas sob o manto da ideologia nazista, é que sua necessidade tornou-se premente e inadiável, sendo que seu conceito passou a ser encarado com base na consciência da diversidade humana, na necessidade do reconhecimento da igualdade de todos em seus direitos civis. ${ }^{41}$

Foi, então, pela vivência das consequências da intolerância que a legislação reconheceu a necessidade da tutela jurídica da tolerância. Com base nisso, contemporaneamente foram editados diversos documentos internacionais sobre o tema, muitos deles referindo-se especificamente à área da Educação, como a Declaração Universal dos Direitos Humanos; ${ }^{42}$ a Declaração de princípios sobre a tolerância, aprovada pela Conferência Geral da Unesco; a Declaração sobre a eliminação de todas as formas de intolerância e discriminação fundadas na religião ou nas convicções; a Declaração de Salamanca sobre Princípios, Política e Prática em Educação Especial; a Declaração sobre os Princípios Fundamentais relativos à Contribuição dos Meios de Comunicação de Massa para o fortalecimento da Paz e da Compreensão Internacional, para a Promoção dos Direitos Humanos e a luta contra o racismo, o Apartheid e o Incitamento à Guerra; a

40 VOLTAIRE. Tratado sobre a intolerância: a propósito da morte de Jean Calas. Tradução de Paulo Neves. 2. ed. São Paulo: Martins Fontes, 2000. p. 136.

41 CARDOSO, Clodoaldo Meneguello. Tolerância: tensão entre diversidade e desigualdade. In: PASSETTI, Edson; OLIVEIRA, Salete (Orgs.). A intolerância e o intempestivo. Cotia: Ateliê Editorial, 2005. p. 49.

42 Fato é que "a presença dos direitos sociais, econômicos e culturais na Declaração Universal dos Direitos Humanos, embora de forma restrita, significou um marco histórico. Não se trata apenas da conquista de um espaço de coexistência com os direitos civis e políticos, mas uma ressignificação do sentido de igualdade e de liberdade, deslocando estes dois valores do plano individual para o coletivo, do jurídico para o social. E com isso também houve, e muitos nem se deram conta, uma mudança qualitativa no sentido de tolerância”. Cf. CARDOSO, Clodoaldo Meneguello. Tolerância: tensão entre diversidade e desigualdade. In: PASSETTI, Edson; OLIVEIRA, Salete (Orgs.). A intolerância e o intempestivo. Cotia: Ateliê Editorial, 2005. p. 55. 
Declaração sobre a Raça e os Preconceitos Raciais; a Declaração Universal sobre a Diversidade Cultural e Plano de Ação; a Declaração Mundial sobre Educação Superior no Século XXI: visão e ação; a Declaração de Hamburgo sobre Educação de Adultos; a Declaração de Nova Délhi sobre Educação Para Todos e a Convenção Relativa à Luta contra as Discriminações na Esfera do Ensino.

Além de ressaltarem a importância da observância da tolerância, tais documentos colaboraram para a expansão de seu sentido, sendo que, hodiernamente, ele pressupõe que o cidadão não sofra violência, não perca seus direitos e não seja discriminado em razão de suas diferenças, de suas convicções religiosas e de sua diversidade étnica ou cultural. ${ }^{43}$

Na atualidade o conceito baseia-se, pois, no respeito ao princípio da dignidade da pessoa humana. Tolerar o outro significa aceitá-lo e respeitá-lo em sua alteridade, "significa ver o outro como ser de direitos. Ao fazer isto, reconhecemos que ele tem tanto direito quanto eu. Tantas verdades quanto as minhas”. ${ }^{4}$

Nesse sentido,

dentro de uma sociedade cada vez mais plural, necessário se faz respeitar e aceitar as diferenças das pessoas para que se concretize uma vivência mais pacífica, e é somente através da tolerância, como pressuposto fundamental para a construção de uma cultura democrática, que se efetivará o reconhecimento e respeito da diferença, da pluralidade, do multiculturalismo e da ética, formando, desse modo, uma sociedade comprometida na defesa das minorias para que essas vejam seus direitos fundamentais concretizados. ${ }^{45}$

A despeito dessa faceta acima mencionada, de respeito à diversidade, a ambiguidade da expressão que o encerra - tolerância -, provoca grandes divergências, uma

43 LEISTER, Margareth Anne; TREVISAN, Elisaide. A tolerância e os direitos humanos: aceitar o multiculturalismo e as diversidades para viver uma cultura democrática. Revista Mestrado em Direito, Osasco, v. 12, n. 1, p. 199-227, jan.-jul. 2012.

44 SILVA, Clemildo Anacleto da. Educação, tolerância e direitos humanos: a importância do ensino de valores na escola. Porto Alegre: Sulina/Universitária Metodista, 2009. p. 142.

45 LEISTER, Margareth Anne; TREVISAN, Elisaide. A tolerância e os direitos humanos: aceitar o multiculturalismo e as diversidades para viver uma cultura democrática. Revista Mestrado em Direito, Osasco, v. 12, n. 1, p. 199-227, jan.-jul. 2012, especialmente p. 202. 
vez que pode ser interpretada como simplesmente suportar o outro, sem, no entanto, aceitálo em sua diversidade. Mesmo havendo uma espécie de boa vontade generalizada em relação à tolerância, seu conceito está imbuído de implicações morais, éticas, religiosas e de relações de poder, podendo ser facilmente inter-relacionado com ideias como compaixão, compreensão e amor ao próximo. ${ }^{46}$

Trata-se aqui da tolerância entendida em seu viés negativo, como indiferença diante do outro, indulgência com a opressão, em nome da tranquilidade de uma vida descompromissada. $^{47}$

Tolerar o outro pode significar, nesse contexto, que ele não é aceito, suas escolhas e modos de vida não são respeitados, mas apenas tolerados pelo fato de ele ser uma pessoa e merecer respeito moral. Fato é que, nesse caso, o tolerante "não tem nenhuma relação positiva para com os valores concretos de seu interlocutor, ele até mesmo pode rejeitá-los em bloco, na expectativa de que seus próprios valores possam, um dia, convencer os que são meramente tolerados”. ${ }^{4}$

Assim,

se viver a experiência do outro, a deficiência do outro, significa aprender a perceber, conviver e tolerar esse outro, também pode significar ser indiferente e intolerante frente ao outro. Literalmente falando, tolerar significa ser indiferente e intolerante frente ao outro [...]. Portanto, tolerante é aquele que suporta alguém, que é capaz de admitir, nos outros, maneiras de pensar, de agir e de sentir diferentes ou mesmo diametralmente opostas às suas. No entanto, a ação de tolerar coloca o tolerante numa posição simétrica de poder, ou seja, permite que ele demarque uma separação que não significa simplesmente uma distância, mas uma diferença nas relações de poder. Aquele que suporta, que tolera

46 PINTO, Celi Regina Jardim. Para além da tolerância. In: BIASOLI-ALVES, Zélia Maria Mendes; FISCHMANN, Roseli (Orgs.). Crianças e adolescentes: construindo uma cultura da tolerância. São Paulo: Edusp, 2001.

47 CARDOSO, Clodoaldo Meneguello. Tolerância: tensão entre diversidade e desigualdade. In: PASSETTI, Edson; OLIVEIRA, Salete (Orgs.). A intolerância e o intempestivo. Cotia: Ateliê Editorial, 2005.

48 REPA, Luiz. Reconhecimento da diferença na teoria crítica. In: TREVISAN, Amarildo Luiz; TOMAZETTI, Elisete Medianeira; ROSSATTO, Noeli Dutra (Orgs.). Diferença, cultura e educação. Porto Alegre: Sulina, 2010. p. 30/31. 
o outro é o mesmo que o hospeda, que o recebe; portanto é aquele que pode depreciá-lo, julgá-lo, aceitá-lo ou não. ${ }^{49}$

Em virtude dessa imprecisão da palavra é que Cortella propõe que o termo seja substituído por acolhimento. Para ele, “acolher não é suportar, aguentar; acolher é, acima de tudo, hospedar em mim, receber comigo, repartir e, portanto, ser capaz de convivência na qual se preserve a individualidade, a liberdade e a dignidade recíprocas”. ${ }^{50}$

Assim, o autor defende que, para concretizar uma tolerância que seja efetivamente acolhimento, mister o respeito a cinco valores fundamentais: humildade, sinceridade, integridade, pluralidade e solidariedade. ${ }^{51}$

Manifestando-se sobre a celeuma, assevera Bobbio que a aceitação da tolerância sempre foi menos polêmica no campo prático, no sentido de sua observância como uma regra de convivência. Em contrapartida, no plano teórico, não poucas vezes ela foi encarada como uma espécie de aceitação forçada do outro e não de respeito e reconhecimento. ${ }^{52}$

Para que possa ser aceita e defendida, deve-se ter em conta sua significação como respeito pela consciência alheia, como direito à liberdade de consciência.

Assim, defende o autor que

o núcleo da ideia de tolerância é o reconhecimento do igual direito a conviver que se reconhece a doutrinas opostas, e portanto do direito ao erro, pelo menos ao erro cometido em boa-fé. A exigência da tolerância

49 LUNARDI- LAZZARIN, Márcia Lise. Os discursos da diferença no contexto das políticas de inclusão: a anormalidade no detalhe. In: TREVISAN, Amarildo Luiz; TOMAZETTI, Elisete Medianeira; ROSSATTO, Noeli Dutra (Orgs.). Diferença, cultura e educação. Porto Alegre: Sulina, 2010. p. 149.

50 CORTELLA, Mário Sérgio. Recusar a destruição da convivência digna! (valores inadiáveis). In: PASSETTI, Edson; OLIVEIRA, Salete (Orgs.). A intolerância e o intempestivo. Cotia: Ateliê Editorial, 2005. p. 170.

51 Idem, ibidem.

52 BOBBIO, Norberto. Elogio da serenidade e outros escritos morais. Tradução de Marco Aurélio Nogueira. São Paulo: Unesp, 2002. 
nasce no momento em que se toma consciência da irredutibilidade das opiniões e da necessidade de encontrar um modus vivendi entre elas. ${ }^{53}$

Note-se, então, que a tolerância está absolutamente comprometida com a diversidade cultural, com a alteridade. ${ }^{54}$ Deve haver tolerância diante da multiplicidade de credos e atitudes, perante o outro que não é igual a mim.

A intolerância, em contrapartida, surge como a não aceitação de uma opinião contrária, com a inconformidade diante da ideia refutada, com a não aceitação do outro. Sobre este último aspecto,

na relação de intolerância, o outro não é considerado verdadeiramente um "outro" e sim alguém semelhante, porém inferior ou um desvio à norma, uma cópia imperfeita de um modelo único. $\mathrm{E}$ isso passa a justificar a expulsão, a dominação, a exploração e o extermínio do outro. ${ }^{55}$

Essa exclusão do diferente como modo de manifestação da intolerância, implica, muitas vezes, a adoção da violência contra ele. É ela a maneira encontrada para aniquilação do que não é aceito pelo grupo social. Enquanto a tolerância impõe o respeito à diversidade cultural, a intolerância se conforma com seu repúdio, com sua desconsideração. Tal atitude,

constitui a consolidação de uma "cultura da violência”, que pode levar a uma "cultura do extermínio", através do não reconhecimento do "outro", considerado diferente, como ser humano, da violência exacerbada, das inúmeras práticas sociais que estimulam o individualismo, a luta por espaço vital, como se a sociedade fosse uma "selva” onde é necessário

53 BOBBIO, Norberto. Elogio da serenidade e outros escritos morais. Tradução de Marco Aurélio Nogueira. São Paulo: Unesp, 2002. p. 153.

54 Levinas é considerado um dos grandes teóricos da alteridade e para ele a alteridade não é pura e simplesmente a existência de outra liberdade ao lado da minha, sendo ela absolutamente estrangeira e não relacionada a mim, o que faz ainda com que o autor defenda que a coletividade não é uma comunhão, já que a proximidade do outro é mantida integralmente a distância. Desse modo, a realização da alteridade demanda um esforço do eu na busca do outro que a ele não se subsume. A relação entre mim e o outro é sempre assimétrica e, por isso, não há reciprocidade. O outro nunca poderá ser totalmente conhecido pelo sujeito, razão pela qual a relação com o outro como alteridade pressupõe a abertura para o desconhecido. Cf. LEVINAS, Emmanuel. Le temps et l'autre. 9. ed. Paris: Quadrige, 2007.

55 CARDOSO, Clodoaldo Meneguello. Fundamentos filosóficos da intolerância. In: CARDOSO, Clodoaldo Meneguello (Org.). Convivência na diversidade: cultura, educação e mídia. Bauru: Unesp; FAAC, 2008. p. 17. 
sobreviver e onde o que vigora é a "lei da seleção natural" que favorece os mais fortes, os mais "competentes”, os mais capazes, os mais agressivos e competitivos, os mais individualistas. ${ }^{56}$

Trata-se de levar ao extremo o fomento da desigualdade e de colocar em ação práticas discriminatórias contra certas pessoas ou certos grupos sociais.

Nas sociedades excludentes a violência é eleita como a resposta, por excelência, a esse conflito social, razão pela qual no Brasil alcançar-se-á a tolerância somente por meio da “diminuição das desigualdades socioeconômicas, da educação para a cidadania, da ampliação da democracia, posto que, amplia-se cada vez mais a ideia de que a convivência democrática em sociedades pluralistas, políticas e culturais, é um dos desafios atuais", ${ }^{57}$ uma vez que "é na desigualdade social que ficam estabelecidas as condições para o preconceito e a intolerância ao ‘diferente'”. 58

Por tudo isso é que discutir a tolerância/intolerância implica examinar o problema da violência. Nesse contexto,

violência e tolerância têm em comum sua oposição ao desdobramento aberto e público de conflitos, já que ambos desconhecem a função produtiva dos conflitos. A violência requer reprimir ou decidir conflitos para implantar a ordem ou para forçar vantagens na luta pelo poder. Os que advogam pela tolerância se inclinam a evadir-se dos conflitos, seja porque os ignorem até onde é possível que lhe imputem cada vez a reponsabilidade do caso a outros grupos ou atores sociais cuja conduta taxam de intolerante..$^{59}$

56 DORNELLES, João Ricardo. Ofensiva neoliberal, globalização da violência e controle social. Discursos Sediciosos: crime, direito e sociedade, São Paulo, v. 7, n. 12, p. 119-137, 2002. p. 133.

57 LEISTER, Margareth Anne; TREVISAN, Elisaide. A tolerância e os direitos humanos: aceitar o multiculturalismo e as diversidades para viver uma cultura democrática. Revista Mestrado em Direito, Osasco, v. 12, n. 1, p. 199-227, jan.-jul. 2012. p. 217.

58 ZONTA, Celso. Igualdade/desigualdade: significações e sentidos no contexto da Psicologia. In: CARDOSO, Clodoaldo Meneguello (Org.). Convivência na diversidade: cultura, educação e mídia. Bauru: Unesp; FAAC, 2008. p.35.

59 GUTIÉRREZ, Carlos B. Tolerancia, despropósito conceptual en nuestros días. In: BORDA, Luis Villar; ROSALES, José María (Ed.). Las razones de la convivencia. Bogotá: Universidad Externado de Colombia, 2007. p. 103-104. 
Importante, por fim, perceber que como a intolerância ao diferente é um problema social, ela aparece também nas microssociedades que a compõem, tal qual na instituição escolar.

\subsection{Violência escolar}

A violência escolar não é um fenômeno novo, uma vez que já era relatada por estudantes na Idade Média. Ocorre que, assim como a violência em geral, ela tem se tornado foco de cada vez mais atenção e preocupação por parte da sociedade.

A expansão dos riscos, característica da pós-modernidade, tem contribuído para a eclosão do medo, inclusive nas escolas, que é muito mais simbólico do que objetivo, mais fictício do que real, donde se aumenta a sensação de insegurança subjetiva, de violência e de diminuição da liberdade dos indivíduos. ${ }^{60}$

A despeito do incremento desse temor, não se pode precisar se a violência escolar efetivamente aumentou, pois responder a essa questão depende do que se reconheceu como violência em cada momento, ou seja, do conceito adotado.

Conforme já se discutiu no excerto anterior,

a percepção de um ato como violento varia, histórica e culturalmente, em função da percepção do limite da força que demanda, da perturbação gerada e/ou sofrimento que promove. Essas variações mostram-se tanto evidentes, quando observada a eclosão de fenômenos violentos em todo o mundo, no terço final do século passado, e as novas mudanças conceituais que provocaram quanto ao entendimento relativo à manifestação da violência nas sociedades. ${ }^{61}$

Em virtude disso, deve guiar o estudo do fenômeno a ideia de que "não pode haver um conhecimento total acerca da violência nas escolas - porque ela só pode ser

60 FLORO, Michel. Questions de violence à l'école: pratiques du champ social. Saint-Agne: Erès, 1996.

61 MENDES, Marcos Baptista. A violência: reflexões teóricas e o processo de mudança nas instituições policiais. In: LINARDI, Carlos José; MIRANDA, Orlando de (Ed.). Violência \& sociedade. São Paulo: Letras e Letras, 2003. p. 90. 
representada de formas parciais, e devemos ou aceitá-las como tal ou nos permitir cair na fantasia da onisciência, que é tudo menos ciência”. 62

Independentemente da constatação de sua expansão ou não, de acordo com Charlot, a violência escolar assume hodiernamente maneiras novas e mais inquietantes.

Essas transformações, continua o autor, referem-se principalmente a três fatores distintos: a violência, por vezes, mesmo isso sendo ainda raro, assume modos extremos, como a aparição de armas de fogo na escola e a morte de alunos ou membros do corpo de funcionários; alunos cada vez mais jovens estão envolvidos nos casos de violência, especialmente entre 8 e 13 anos; e cada vez mais conjecturas externas à escola influem no seu dia a dia. ${ }^{63}$

Note-se, pois, que existe violência nas escolas, que elas provavelmente ocorrem mais do que no passado, que há casos de infrações graves nos estabelecimentos de ensino, mas que esses fenômenos são supervalorizados e não representam a realidade escolar.

O que é certo é que esse medo reverencial que se dissipa no ambiente escolar acaba por reinventar perversamente a escola, transformando-a em um local de sociabilidade cindida e de ausência de tolerância. ${ }^{64}$

É forçoso reconhecer, que independentemente da quantidade de violência existente, a questão está imbuída de um componente simbólico bastante importante que se refere ao fato de que as pessoas não esperam ou não admitem que as escolas possam ser

62 DEBARBIEUX, Éric. "Violência nas escolas": divergências sobre palavras e um desafio político. In: DEBARBIEUX, Éric; BLAYA, Catherine (Orgs.). Violência nas escolas e políticas públicas. Tradução de Patrícia Zimbres. Brasília: Unesco, 2002. p. 65.

63 CHARLOT, Bernard. Violence à l'école: état de recherches en France et... quelques questions dans une perspective girardienne. In: MARTINEZ, Marie-Louise; SEKNAADJÉ-ASKÉNAZI, José (Orgs.). Violence et éducation: de La méconnaissance à l’action éclairée. 2. ed. Paris: L’Harmattan, 2002.

64 SPOSITO, Marília Pontes. A redução da violência escolar como desafio democrático. Revista do ILANUD, São Paulo, n. 23, 107-117, 2002. 
locais onde a insegurança e a criminalidade se manifestam. Por isso, "a violência na escola choca, ainda que pequena, porque ali é um lugar onde ela não deveria existir”. 65

Ademais, importante perceber que nos últimos anos tem aumentado cada vez mais o número de jovens com acesso à escola, o que faz com que, em termos brutos, o montante de casos violentos também siga essa tendência. Nesse diapasão, assevera Kahn que "é natural, portanto, dado o tamanho da população, que ocorram casos de violência dentro das escolas, assim como ocorreria dentro de conventos, se ali houvesse 56 milhões de pessoas". 66

A visão construída pela mídia e pela sociedade, colocando o adolescente na posição de autor da violência (o que justifica a demanda pela redução da maioridade penal, por exemplo), além de não colaborar em nada no enfrentamento do problema, acaba por determinar a atuação dos professores e da comunidade em relação ao tema.

Na França, país onde a questão da violência escolar está no centro dos debates sobre a escola, os incidentes relativos à prática de violência não verbal, nos anos de 1998 e 1999, não ultrapassaram os 0,02\% dos casos. Nos Estados Unidos, por sua vez, a chance de uma criança em idade escolar se encontrar em meio a um tiroteio na escola é de uma em um milhão.. ${ }^{67}$

Entretanto, uma gama de medidas foi tomada nas últimas décadas para tentar evitar a reprodução da violência nas escolas norte-americanas. Nesse diapasão, revela Devine que

dentre o grande número de produtos de segurança escolar que foram lançados no mercado a partir da tragédia de Littleton, em abril de 1999, estão mochilas escolares de vinil transparente (que permitem que os funcionários da escola vejam se o aluno carrega uma arma); software de "planejamento de crises”, para ajudar os distritos escolares a lidar com

65 KAHN, Túlio. Efeitos das mudanças no sistema escolar sobre a violência. Revista do ILANUD, São Paulo, n. 23, 79-105, 2002. p. 82.

66 Idem, ibidem, p. 82.

67 DEBARBIEUX, Éric. "Violência nas escolas": divergências sobre palavras e um desafio político. In: DEBARBIEUX, Éric; BLAYA, Catherine (Orgs.). Violência nas escolas e políticas públicas. Tradução de Patrícia Zimbres. Brasília: Unesco, 2002. 
futuras tragédias escolares; software para monitorar sites violentos na Internet; manuais de prevenção da violência; e programas de treinamento de professores que dão emprego a consultores de "segurança escolar”. $\mathrm{Na}$ escola secundária de Buffalo Grove, em Illinois, para tomar um único exemplo, o distrito anunciou o plano de instalar 96 câmeras de segurança espalhadas por toda a escola. ${ }^{68}$

A esse respeito Christie conta que em seus dias de escola um episódio sempre se repetia no pátio onde acontecia o recreio. Formavam-se grupos de estudantes ao redor de dois colegas que travavam batalha um contra o outro.

A peleja, conta Christie, durava pouco tempo, pois logo era reprimida por um professor, que levava os envolvidos para a direção da instituição. Hoje, porém, esses jovens poderiam ser levados à polícia, ou a polícia poderia já estar no interior do colégio, e essa, não excepcionalmente, é a solução dada ao caso. ${ }^{69}$

Também no Brasil, em pesquisa realizada pelo NEV/USP nos anos de 2001 e 2003, no município de São Paulo e também nos distritos de Jardim Ângela, Capão Redondo e Jardim São Luís sobre as representações que a população em geral tem da violência escolar e das experiências de exposição a ela por parte dos jovens que frequentam as escolas, chegou-se a algumas conclusões importantes.

Ao contrário do veiculado pela mídia, apurou-se que a violência criminosa e as agressões físicas contra os professores, ambas perpetradas pelos estudantes, não são frequentes. Em contrapartida, constatou-se que a violência que se manifesta nas escolas é, precipuamente, não criminosa, incluindo atos de intimidação, preconceitos e desrespeitos ao outro.

68 DEVINE, John. A mercantilização da violência escolar. In: DEBARBIEUX, Éric; BLAYA, Catherine (Orgs.). Violência nas escolas e políticas públicas. Tradução de Patrícia Zimbres. Brasília: Unesco, 2002. p. 215.

69 CHRISTIE, Nils. Una sensata cantidad de delito. Tradução de Cecília Espeleta e Juan Iosa. Buenos Aires: Del Puerto, 2004. 
O que ocorre é que crimes e delitos tornam-se mais publicizados e a violência no âmbito escolar praticada contra um adulto torna-se mais notável em cotejo com a violência que se manifesta entre os próprios alunos. ${ }^{70}$

Para os estudantes, ainda, a violência presente em seus bairros é bem mais acentuada do que aquela vivenciada no ambiente escolar, o que pode indicar que a instituição ainda pode ser encarada como um reduto de proteção contra as conjecturas externas.

De todo modo, “é preciso notar que grande parte das ocorrências escolares diz respeito a microviolências, que não chegam a colocar em risco a integridade física das pessoas, como as agressões verbais depreciativas”. ${ }^{71}$

Em outra pesquisa, dessa vez realizada por Lucinda, Nascimento e Candau, foram entrevistados trinta e um professores e professoras atuantes no ensino público fundamental do Rio de Janeiro. Quando questionados sobre as situações de violência mais presentes nas escolas, dezoito destes mencionaram as brigas e as agressões verbais entre os alunos como as mais constantes. A segunda mais mencionada foi a violência doméstica, cujos reflexos são sentidos sobremaneira no ambiente educacional. ${ }^{72}$

Desse modo, pode-se averiguar que a violência escolar é um fenômeno dotado de persistência espaçotemporal, pois sempre existiu e continua existindo atualmente em diversas partes do globo, o que justifica, desde logo, o seu estudo pela Criminologia e por outras áreas da ciência.

Contudo, sem minimizar a importância e a danosidade do fenômeno, mister que sua análise não se contamine por tendências expansionistas, que enxergam o fenômeno maior do que ele realmente é.

70 DUPÂQUIER, Jacques. La violence en milieu scolaire. Paris: Presses Universitaires de France, 1999.

71 RUOTTI, Caren. Exposição à violência escolar e percepções sobre suas causas. In: RUOTTI, Caren; ALVES, Renato; CUBAS, Viviane de Oliveira (Orgs.). Violência na escola: um guia para pais e professores. São Paulo: Andhep/Imprensa Oficial do Estado de São Paulo, 2006. p.160-161.

72 LUCINDA, Maria da Consolação; NASCIMENTO, Maria das Graças; CANDAU, Vera Maria. Escola e violência. 2. ed. Rio de Janeiro: DP\&A, 2001. 
Deve-se ter em mente, então, que

os atores da escola percebem inegavelmente a violência. Convém relativizar sua importância, recordando que apenas $17 \%$ dos alunos experimentam um vivo sentimento de violência nos estabelecimentos, o que não implica necessariamente a presença de uma violência objetivamente mensurável. ${ }^{73}$

\subsubsection{Definições sobre a violência escolar}

Tema alvo de recentes interesses, a significação da violência escolar está em constante construção e redefinição. Fato é que os pesquisadores do tema estabelecem seus conceitos segundo referenciais diversos, sendo certo ainda que muitos estudos sobre o assunto não deixam claro o conceito teórico do qual partem ou baseiam-se apenas nas percepções que os alunos têm sobre o fenômeno.

Abramovay, Lima e Varella ressaltam que cada país utiliza-se de terminologias diversas para tratar da violência escolar.

Na Inglaterra, por exemplo, além de a expressão violência contar com grande carga emocional, ela costuma aludir meramente à violência física. Nos Estados Unidos os estudos sobre o tema geralmente são referidos pela expressão delinquência juvenil. Na França recorre-se à expressão incivilidade em vez de violência. ${ }^{74}$

De todo modo, importante perceber que se trata de um fenômeno heterogêneo, sendo que sob essa insígnia pode-se estar pesquisando a violência dos alunos contra os professores, dos docentes e da direção contra os alunos ou mesmo das manifestações violentas entre o próprio corpo discente da unidade escolar.

Note-se que em todas elas um dos polos envolvidos na agressão contempla os alunos da instituição. Assim, não se podem olvidar as características peculiares de seus

73 BARRÈRE, Anne; SEMBEL, Nicolas. A sociologia da escola. Tradução de Maria Stela Gonçalves. São Paulo: Loyola, 2006. p. 102-103.

74 ABRAMOVAY, Miriam; RUA, Maria das Graças. Violências nas escolas. 4. ed. Brasília: Unesco, 2004. 
maiores implicados, os jovens estudantes, já que é nessa faixa etária que grande parte das violências se produz. Para eles, não excepcionalmente, a violência é o recurso utilizado para afirmação de um papel social, de um lugar dentro do grupo.

Nesse sentido, asseveram Cara e Gauto que

a fase da juventude está intimamente ligada à formação da identidade, à afirmação pessoal e à busca por pertencimento. Esse processo é muito mais do que ter uma roupa, é buscar ser diferente, mesmo que isso signifique ser igual a todo mundo. A forma de se vestir, de pensar e agir constitui uma linguagem simbólica, permeada e inseparável, de valores sociais e culturais. A violência aparece também como um recurso à preservação da autoimagem: ser violento e/ou envolvido com a criminalidade confere status social. A vida social compartilhada em grupos é fundamental para o jovem, pois oferece apoio e proteção. A violência enquanto afirmação de identidade necessita de uma plateia, já que comunica ao se romperem as regras e recorrerem à violência, quem é e o lugar que quer ocupar. ${ }^{75}$

Diante disso, se uma possibilidade de compreensão da violência escolar é esse desejo de reconhecimento, aceitação e inclusão do jovem, deve ser mostrado a ele que existem outras maneiras melhores de ser valorizado. A educação, nesse sentido, possibilita a “ampliação do mundo, significa ampliação do tempo, criação de um mundo com oxigênio, com novas palavras e experiências que nos podem ajudar a construir narrativas sobre a história e, dessa forma, mudar a história”, ${ }^{76}$

Ademais, também

"o que é caracterizado como violência varia em função do estabelecimento escolar, da posição de quem fala (professores, diretores,

75 CARA, Daniel; GAUTO, Maitê. Juventude: percepções e exposição à violência. In: ABRAMOVAY, Miriam; ANDRADE, Eliane Ribeiro; ESTEVES, Luis Carlos Gil. Juventudes: outros olhares sobre a diversidade. Brasília: Ministério da Educação, Secretaria da Ação Continuada, Alfabetização e Diversidade; Unesco, 2007. p. 182-183.

76 SCHILLING, Flávia. Violência na escola. In: WESTPHAL, Márcia Faria; BYDLOWSKI, Cynthia Rachid (Ed.). Violência e juventude. São Paulo: Hucitec, 2010. p. 230. 
alunos...), da idade e do sexo; sendo, portanto, uma conceituação ah hoc mais apropriada ao lugar, ao tempo e aos autores que a examinam. ${ }^{77}$

Em pesquisa realizada por Clémence com alunos e professores de doze escolas da Suíça, constatou-se que os mestres ostentam uma definição mais ampla da violência em cotejo com os alunos. Para estes, violência é a agressão intencional, especialmente física, a pessoas em desigualdade de condições. A oposição aos professores, por exemplo, é encarada por eles como uma brincadeira e não como um ato violento.

Já para os educadores, as agressões entre os pares e as agressões verbais são consideradas manifestações violentas. ${ }^{78}$

A diferente percepção sobre o feito sustentada por alunos e professores, a despeito de sua contraditoriedade, justifica-se em razão da formação cultural diversa dos professores que permite que eles tenham maior acuidade ao defrontarem-se com o problema.

Em um espaço de convívio forçado de mestres, funcionários e estudantes, com problemas e expectativas diferentes em relação ao ambiente circundante, é certo que a violência pode ter diversas direções e distintos atores.

Nesse diapasão, podem-se distinguir, essencialmente, três tipos de violência relacionadas ao ambiente escolar: a violência contra a escola, a violência da escola e a violência na escola.

Vislumbram-se entre os atos de violência contra a escola as depredações de suas instalações, o desvio de verbas destinadas à educação, os baixos salários pagos aos professores, a falta de preocupação em relação às propostas educacionais, a falta de estrutura para a realização da atividade educativa, entre outros.

77 ABRAMOVAY, Miriam; LIMA, Fabiano; VARELLA, Santiago. Percepções dos alunos sobre as repercussões da violência nos estudos e na interação social na escola. In: ABRAMOVAY, Miriam. Escola e violência. 2. ed. Brasília: Unesco, UCB, 2003. p. 95.

78 CLÉMENCE, Alain. Violência e incivilidade na escola: a situação na Suíça. In: DEBARBIEUX, Eric; BLAYA, Catherine (Orgs.). Violência nas escolas: dez abordagens europeias. Tradução de Patrícia Zimbres e Paula Zimbres Brasília: Unesco: 2002. 
Trata-se de ações que colocam em dúvida a própria qualidade do serviço prestado pela instituição aos estudantes.

A violência da escola é reflexo das violências existentes na sociedade onde ela se insere. Incluem-se aqui conflitos entre as gerações, diferenciações de raça, de status, de religião, a exclusão social e do mercado de trabalho. É a discriminação, o não ensinar, e pode ser praticada entre os alunos ou pelos alunos contra os professores.

Nesse sentido, a escola produz a violência quando não oferece espaços para que o aluno entenda a complexidade da vida, quando, em seu funcionamento, fabrica o fracasso escolar.

Em consonância com essa ideia é que Debarbieux sustenta que “a maior parte dos sociólogos franceses considera a exclusão social como uma das grandes causas da violência nas escolas". ${ }^{79}$

A violência na escola, por sua vez, é caracterizada por ações como o furto, as agressões, as ameaças e as brigas, nada mais do que contingências das violências contra e da escola.

Não obstante a análise acima apresentada, ela não é pacífica entre os teóricos da educação.

Dupâquier distingue, formalmente, quatro tipos de violência escolar: violência contra bens individuais, a exemplo do roubo; violência contra a propriedade coletiva, tal qual incêndio e vandalismo; violência verbal ou moral contra as pessoas, ou seja, contra alunos, professores e funcionários da escola e violência psíquica. ${ }^{80}$

Já Chesnais, diferencia as violências em física, econômica e moral ou simbólica. A física, que inclui a sexual, seria a de maior correção etimológica, sendo representada pela agressão aos bens mais importantes de uma pessoa, tal qual sua vida,

79 DEBARBIEUX, Éric. "Violência nas escolas": divergências sobre palavras e um desafio político. In: DEBARBIEUX, Éric; BLAYA, Catherine (Orgs.). Violência nas escolas e políticas públicas. Tradução de Patrícia Zimbres. Brasília: Unesco, 2002. p. 84. 
saúde e liberdade. A violência econômica consiste na destruição do patrimônio alheio. Por fim, a violência moral ou simbólica, de conteúdo precipuamente subjetivo, é a baseada na construção da autoridade. ${ }^{81}$

Há teóricos, ainda, que optam por trabalhar com a violência com base no sentimento de vitimação. É violento o ato que a vítima, seu destinatário, reconhece como tal. Note-se, porém, que isso pode fazer com que se insiram nesse conceito desde violações simples, como quebrar um lápis, até os atos mais violentos. ${ }^{82}$

Evidente, pois, diante das percepções das violências nas escolas apresentadas, que não obstante suas dessemelhanças, já foram superadas as ideias de que o ato violento encerra-se na agressão física ou no estrito conceito de crime. Ademais, destaque-se o fato de a violência emanar de fontes diversas, de diferentes autores. Assim, alunos, mestres e a própria escola e sua organização, ou desorganização, podem realizá-la.

Desse modo, Abramovay e Rua destacam ser recomendado "escutar as vítimas e a comunidade acadêmica, para construir noções sobre violência mais afins com as realidades experimentadas e os sentidos percebidos pelos envolvidos”. ${ }^{83}$

Diante disso, Debarbieux, mesmo reconhecendo os problemas advindos de sua posição, defende que a violência escolar deve ser definida de maneira ampla, incluindo em sua conceituação atos irrelevantes para o sistema jurídico, bem como atos considerados violentos para suas vítimas. ${ }^{84}$

Hodiernamente, tem-se identificado que o estudo das manifestações conflitivas nas escolas, precipuamente a que se refere à praticada entre os pares - tema central do presente trabalho -, vem ganhando importância desde a década de 1990. Entretanto, apenas

81 CHESNAIS, Jean-Claude. Histoire de la violence. Paris: Robert Laffont, 1981.

82 CHARLOT, Bernard. Violence à l'école: état de recherches en France et... quelques questions dans une perspective girardienne. In: MARTINEZ, Marie-Louise; SEKNAADJÉ-ASKÉNAZI, José (Orgs.). Violence et éducation: de La méconnaissance à l'action éclairée. 2. ed. Paris: L’Harmattan, 2002.

83 ABRAMOVAY, Miriam; RUA, Maria das Graças. Violências nas escolas. 4. ed. Brasília: Unesco, 2004. p. 73.

84 DEBARBIEUX, Éric. "Violência nas escolas": divergências sobre palavras e um desafio político. In: DEBARBIEUX, Éric; BLAYA, Catherine (Orgs.). Violência nas escolas e políticas públicas. Tradução de Patrícia Zimbres. Brasília: Unesco, 2002. 
em março de 2001 aconteceu o primeiro evento de repercussão internacional sobre o tema, a Conferência Mundial intitulada Violência nas escolas e políticas públicas, realizada em Paris, a qual contou com a presença do ministro da Educação e do primeiro-ministro da França. $^{85}$

Atualmente é a violência contra os pares e contra a propriedade que vem sendo o foco principal dos estudos na educação, seguidas pela violência de alunos contra professores e de professores contra os alunos. ${ }^{86}$

Mesmo diante de tantas facetas e modos de representação e definição da violência escolar, é comum que as escolas neguem sua existência, seja para preservar a boa imagem da instituição, de seus professores e demais funcionários ou mesmo como maneira de sobreviver diante da sua incapacidade em lidar com o fenômeno. ${ }^{87}$

Entretanto, tal atitude apenas serve para dificultar a elucidação e a solução da violência praticada no ambiente de ensino. Inclusive, por vezes, essa iniciativa pode fomentar as práticas violentas dentro e fora da instituição.

Fato é que fica evidente que "não há somente uma dificuldade em lidar com a violência nas escolas; há uma dificuldade em lidar com a violência de modo geral”. ${ }^{8}$

\subsubsection{Transgressão, incivilidade e violência escolar}

Mesmo diante das elucidações apresentadas até aqui, ainda resta diferenciar a violência escolar de outros comportamentos que com ela se confundem, já que é parte do estudo de determinado fenômeno a exata compreensão do seu sentido.

85 As palestras apresentadas na Conferência foram transformadas no livro Violência nas escolas e políticas públicas.

86 ABRAMOVAY, Miriam; RUA, Maria das Graças. Violências nas escolas. 4. ed. Brasília: Unesco, 2004.

87 CUBAS, Viviane. Violência nas escolas: como defini-la? In: RUOTTI, Caren; ALVES, Renato; CUBAS, Viviane de Oliveira (Orgs.). Violência na escola: um guia para pais e professores. São Paulo: Andhep/Imprensa Oficial do Estado de São Paulo, 2006.

88 ARAÚJO, Carla. A violência desce para a escola: suas manifestações no ambiente escolar e a construção da identidade dos jovens. 2. ed. Belo Horizonte: Autêntica, 2004. p. 57. 
Em virtude da aparente semelhança entre violência, transgressão e incivilidade é que costuma se expandir o primeiro conceito, denominando-se violência aquilo que não o é, e tratando todos como se violência fossem.

Ocorre que fenômenos diferentes merecem também soluções diferentes. Excepcionalmente, pode ser que a única resposta para um ato de violência seja a ofertada pelo sistema penal. Entretanto, essa nunca será a resposta aduada diante da transgressão e da incivilidade.

Nesse diapasão, Charlot distingue transgressão, incivilidade e violência no ambiente escolar. A transgressão é o desrespeito a uma norma. Trata-se de um termo mais geral, que não se refere necessariamente a uma agressão. A indisciplina e a desobediência, por exemplo, são transgressões, mas não são necessariamente agressões. O termo refere-se, pois, à violação das regras do estabelecimento de ensino.

Nesse contexto, a indisciplina é precipuamente encarada em um sentido negativo, como falta da disciplina exigida pela escola. Porém, há um sentido positivo que a acompanha, em sua correlação com ousadia, incorfomismo.

É em seu viés negativo que ela se confunde com a violência. Nesse diapasão, refere Camacho que

um olhar superficial sobre as condutas dos estudantes no espaço escolar urbano traz o risco de uma leitura incorreta de que disciplina e violência são dois tipos de ação bem definidos. Somente o mergulhar profundo na realidade escolar é que mostra a dificuldade de compreender que existe uma fluidez dos limiares da violência e da indisciplina. ${ }^{89}$

A incivilidade é um desrespeito à pessoa, tal qual o ato de injuriar alguém. Trata-se da violação do código social de boas maneiras, sendo certa a problemática existente no fato de esse referencial de comportamentos não ser o mesmo em todos os meios sociais.

89 CAMACHO, Luiza Mitiko Yshiguro. Violência e indisciplina nas práticas escolares de adolescentes: um estudo das realidades de duas escolas semelhantes e diferentes entre si. 2000. 265f. Tese (Doutorado em Educação) - Faculdade de Educação - Universidade de São Paulo [2000]. p. 38. 
O conceito deriva da definição de Elias, em sua obra $O$ processo civilizador, em que o autor discute a questão da civilidade e da transformação dos costumes. ${ }^{90}$

Charlot refere que nas escolas francesas os grandes problemas são a incivilidade e a indisciplina (transgressão) e que os incidentes de violência são muito menos comuns. ${ }^{91}$

Diversos autores, especialmente na França, trabalham com a ideia da incivilidade no meio escolar, apesar da ambiguidade de sentidos que a expressão apresenta. Debarbieux acredita que esse termo explica melhor as ocorrências do meio escolar, já que representa as infrações à ordem estabelecida, ao código de boas maneiras, e não necessariamente uma conduta considerada criminosa pelo ordenamento jurídico penal do local. Para o autor, a expressão abarca uma gama de atos distintos, tal como a indelicadeza, a má criação e o vandalismo. Ademais, assevera Debarbieux que as incivilidades podem tornar-se mais traumáticas por serem negligenciadas pelos estabelecimentos escolares, tomando assim, por vezes, o modo de violência simbólica. ${ }^{92}$

Em consonância com o pensamento de Debarbieux, Laterman defende que as incivilidades estão relacionadas ao funcionamento e às relações estabelecidas no ambiente escolar, tal qual a falta de autoridade, a repetência, a desorganização administrativa, bem como a falta de diálogo e de trabalho pedagógico. ${ }^{93}$

Focando sua análise na sociedade brasileira, Laterman ainda assevera que

as incivilidades devem ser compreendidas na nossa realidade brasileira como algo mais do que a falta de polidez. As incivilidades representam um exercício de cidadania, de imposição da identidade própria ao espaço

90 Cf. ELIAS, Norbert. O processo civilizador. Tradução de Ruy Jungmann. Rio de janeiro: Jorge Zahar, 1993. v. 1.

91 CHARLOT, Bernard. Violence à l'école: état de recherches en France et... quelques questions dans une perspective girardienne. In: MARTINEZ, Marie-Louise; SEKNAADJÉ-ASKÉNAZI, José (Orgs.). Violence et éducation: de La méconnaissance à l'action éclairée. 2. ed. Paris: L’Harmattan, 2002.

92 DEBARBIEUX, Éric. Violência nas escolas: divergências sobre palavras e um desafio político. In: DEBARBIEUX, Éric; BLAYA, Catherine (Orgs.). Violência nas escolas e políticas públicas. Tradução de Patrícia Zimbres. Brasília: Unesco, 2002. p. 59-92.

93 LATERMAN, Ilana. Violência e incivilidade na escola: nem vítimas, nem culpados. Florianópolis: Letras Contemporâneas, 2000. 
social, um modo de influenciar na vida social. Para além de aceitar a proposta política da exclusão social, as incivilidades apontam para uma resposta marginal daqueles que não têm vez nem voz [...] as incivilidades, ainda que ao seu modo torto e, talvez, inconsciente, são também (e não só) a ação possível de indivíduos destituídos de direitos e, de fato, em se defrontar e afrontar o que, na escola, representa o estado. ${ }^{94}$

Logo, para ela, a incivilidade tem dois sentidos diversos: um que se refere ao respeito nas relações pessoais e outro que se identifica com a cidadania, sendo certo que as escolas brasileiras têm de lidar com essas duas facetas da incivilidade, já que elas, “como agente socializador, têm o papel de desenvolver cidadãos (num país com um difícil processo de cidadania) e autonomia moral (diante da relativização ética)", 95

Já para Dupâquier, o termo incivilidade é um eufemismo e tem o inconveniente de referir-se a muitos comportamentos, bastante diferentes entre si, como desrespeito, insulto, provocação e ameaça. ${ }^{96}$

De todo o modo, a despeito das ambiguidades geradas pela expressão, "particularmente na França, é consenso que a incivilidade - sendo expressão de agressividade, insensibilidade para com direitos dos outros ou violência - requer cuidados para que as relações sociais no meio escolar sejam menos hostis”. ${ }^{97}$

A violência, por sua vez, conforme discutido no excerto anterior, é uma maneira particular de transgressão, que implica um grave atentado à integridade física ou moral de uma pessoa.

Ela pode dirigir-se, pois, contra a pessoa, mas também contra o prédio escolar, como os atos de incendiar uma escola ou atentar contra a integridade do estabelecimento.

94 LATERMAN, Ilana. Violência e incivilidade na escola: nem vítimas, nem culpados. Florianópolis: Letras Contemporâneas, 2000. p. 131-132.

95 Idem, ibidem, p. 42.

96 DUPÂQUIER, Jacques. La violence en milieu scolaire. Paris: Presses Universitaires de France, 1999.

97 ABRAMOVAY, Miriam; RUA, Maria das Graças. Violências nas escolas. 4. ed. Brasília: Unesco, 2004. P. 74. 
Ela também pode ser uma violação à lei penal, mas mesmo assim, nem toda violação da lei deve ser tida como ato de violência, uma vez que, numa perspectiva criminológica crítica, a legitimidade das normas vigentes também é discutível.

Definidos os parâmetros do comportamento violento, em cotejo com os atos a ele assemelhados, convém indagar acerca da razão pela qual ela ocorre, o porquê ela se produz e como se explica, o que será feito no item subsequente.

\subsubsection{Explicações para a violência escolar}

Numa tentativa de organizar as ideias existentes sobre o fenômeno, e não de limitá-las, podem-se identificar três enfoques que - combinados ou não - visam a explicar a violência que ocorre no interior das escolas. O teórico-explicativo estrutural considera a violência escolar como um desdobramento natural da crise estrutural da sociedade que a contém. O enfoque teórico-explicativo individual busca nos próprios sujeitos a explicação para a violência, perquirindo se ela advém de aspectos biológicos, hereditários e ligados à personalidade do estudante. O enfoque teórico-explicativo institucional busca saber como o ambiente escolar colabora na produção da violência que ocorre em seu bojo.

No mesmo sentido, revelam Abramovay e Rua que

tanto na literatura estrangeira como na nacional, os trabalhos sobre violências nas escolas, recorrem a múltiplas associações das ocorrências com características e atributos das vítimas e dos agressores; ou com as distintas instituições e ambientes pelos quais circulam os jovens, que, por sua vez, têm dinâmicas sociopolíticas singulares. ${ }^{98}$

Para Silva, no que se refere à produção da violência escolar, "assumir uma ou outra razão como a única ou a mais importante é adotar um posicionamento estreito, limitado e parcial, que em nada ajuda no entendimento do problema”. 99

98 ABRAMOVAY, Miriam; RUA, Maria das Graças. Violências nas escolas. 4. ed. Brasília: Unesco, 2004. p. 75.

99 SILVA, Nelson Pedro. Ética, indisciplina e violência nas escolas. 2. ed. Rio de Janeiro: Vozes, 2004. p. 26. 
De todo modo, a mais criticável perspectiva, precipuamente se considerada isoladamente, é a que se refere à assunção da violência escolar como decorrente de características individuais dos autores. Acredita-se, nesses termos, que a violência que do autor emana provém do seu nascimento e o acompanhou durante toda a sua trajetória de desenvolvimento.

Tal posição é extremamente conservadora e reducionista já que atribui a violência apenas à ação do sujeito, cujo problema de personalidade ou de herança genética se sobressai. Ademais, ela tende à inação e à consideração do indivíduo como bode expiatório da violência que ocorre em determinado ambiente.

Se esse tipo de desvio acontece, se problemas de personalidade ou hereditários tornam alguém violento, essa perspectiva deve ser tida como excepcional, sob pena de mascarar as questões do entorno que estimulam a agressão.

Conforme assevera Shecaira, "na atualidade, parece demonstrado que tais fatores, no que concerne a influenciarem a conduta delitiva, caso existam, têm mínima participação". 100

Aproximando-se do primeiro entendimento - o de que a violência escolar é reflexo e decorrência da ordem social -, Lucinda, Nascimento e Candau defendem que "a violência na escola não pode ser analisada como um fenômeno isolado; ela é parte de um processo mais amplo, que vai além da escola, pois implica uma série de fatores que dizem respeito ao contexto social como um todo". ${ }^{101}$

Nesse sentido, a própria organização social e os problemas que nela se apresentam irradiam-se para dentro das escolas, produzindo violência.

Podem ser identificadas, assim, algumas causas exógenas que interferem, e até certo ponto, produzem a violência escolar: nos países da Europa e nos Estados Unidos,

100 SHECAIRA, Sérgio Salomão. Sistema de garantias e o direito penal juvenil. São Paulo: Revista dos Tribunais, 2008. p. 130.

101 LUCINDA, Maria da Consolação; NASCIMENTO, Maria das Graças; CANDAU, Vera Maria. Escola e violência. 2. ed. Rio de Janeiro: DP\&A, 2001. p. 14. 
precipuamente, a composição étnica/racial em conflito com a nacional; a família; a mídia e o ambiente em que se situa a escola, tal qual o bairro e também a sociedade amplamente considerada. $^{102}$

Importante deixar claro que essa influência da dimensão social sobre a escolar não significa, entretanto, a existência de uma relação direta entre pobreza e violência.

Nesse sentido revela Abramovay que “é possível observar a presença de escolas seguras em bairros ou áreas reconhecidamente violentas, e vice-versa, sugerindo que não há determinismos nem fatalidades, mesmo em períodos e áreas caracterizadas por exclusões". 103

Também assevera Laterman que

a injustiça social, não pode nos levar a concluir que a pobreza gera violência. É o conjunto dos fatores, injustiça social, individualismo, consumismo, falta de oportunidades numa sociedade meritocrática, crise, que explica melhor a opção destes jovens pela violência, pelo machismo, pelo banditismo. ${ }^{104}$

Charlot, ao analisar se a violência é um fenômeno específico das escolas da periferia, ressalta que, geralmente, os crimes de violência extrema são perpetrados na França por alunos da burguesia ou da alta burguesia, mas que as escolas localizadas nos bairros mais pobres são mais violentas se comparadas com as dos bairros mais ricos. Entretanto, assevera o autor, no mesmo sentido dos demais, que não há um determinismo entre pobreza e violência, sendo que, o que ocorre é que geralmente as escolas com um índice elevado de precariedade social costumam ter um clima escolar pior, considerando-se

102 ABRAMOVAY, Miriam; RUA, Maria das Graças. Violências nas escolas. 4. ed. Brasília: Unesco, 2004.

103 ABRAMOVAY, Miriam. Violências nos cotidianos das escolas. In: ABRAMOVAY, Miriam (Org.). Escola e violência. 2. ed. Brasília: Unesco, UCB, 2003. p. 72-73.

104 LATERMAN, Ilana. Violência e incivilidade na escola: nem vítimas, nem culpados. Florianópolis: Letras Contemporâneas, 2000. p. 32-33. 
que há ainda instituições de ensino em que o mal-estar escolar não se manifesta por atos de violência, e sim por um grande absenteísmo. ${ }^{105}$

Note-se, então, que na visão de Charlot a violência escolar apresenta uma dimensão social, uma vez que as tensões vivenciadas no cotidiano escolar são geralmente de ordem social. Mas ele ressalta que é preciso ir além dessa afirmação e perceber que a violência escolar é também consequência da ligação estreita entre sucesso escolar e inserção profissional futura. Em outros termos, as tensões vividas na escola são também criadas pela própria instituição e também na sala de aula.

Nesse diapasão, defende o autor que se uma sociedade não pode atribuir às suas escolas objetivos claros e não contraditórios, elas ficam ameaçadas de perder seu sentido e produzir violência. Para ele, se a instituição não respeita a dignidade de seus alunos como pessoas e não os ensina conteúdos que efetivamente valem a pena ser aprendidos, o sistema e os estudantes ficam ameaçados de violência. ${ }^{106}$

Com isso, Charlot integra em sua análise a visão de que a violência escolar deriva da conjuntura social, bem como das vicissitudes do próprio sistema de ensino, unindo as perspectivas estrutural e institucional mencionadas no início desse excerto.

Em consonância com esse pensamento assevera Dupâquier que a violência na escola deriva da crise da sociedade francesa, em geral, e, em particular, da crise do sistema escolar. $^{107}$

Ainda de modo semelhante, Waiselfisz e Maciel defendem que

para estudar a problemática da violência nas escolas é necessário entender o fenômeno não apenas como um desdobramento de uma crise estrutural mais ampla na sociedade. É preciso, sobretudo, atentar para o que é que mudou (ou não mudou) no contexto pedagógico atual das

105 CHARLOT, Bernard. Violence à l'école: état de recherches en France et... quelques questions dans une perspective girardienne. In: MARTINEZ, Marie-Louise; SEKNAADJÉ-ASKÉNAZI, José (Orgs.). Violence et éducation: de La méconnaissance à l’action éclairée. 2. ed. Paris: L’Harmattan, 2002.

106 Idem, ibidem.

107 DUPÂQUIER, Jacques. La violence en milieu scolaire. Paris: Presses Universitaires de France, 1999. 
instituições escolares para comportar atos de violência outrora inimagináveis. ${ }^{108}$

Nesse diapasão, Abramovay conclui que

a instituição escolar vem enfrentando profundas mudanças com o aumento das dificuldades cotidianas, que provêm tanto dos problemas de gestão e das suas próprias tensões internas quanto da efetiva desorganização da ordem social que se expressa mediante fenômenos exteriores à escola, como a exclusão social e institucional, a crise e o conflito de valores e o desemprego. ${ }^{109}$

Com as rápidas transformações do mundo contemporâneo, somadas à multiplicidade e fluidez de modelos disponíveis, têm-se modificado os modos de vida que antes pareciam tão certos e eficazes. Exemplo maior dessa realidade refere-se aos papéis da escola e, respectivamente, da educação nos dias atuais. ${ }^{110}$

A escola sofre hodiernamente de uma crise de identidade, ela "está passando por uma crise relacionada à socialização, e ela tem enfrentado dificuldades na transmissão das normas e dos valores gerais da sociedade”. 111

Outrora $^{112}$ seu papel era mais bem definido e sua importância, crucial. Nesse sentido, assevera Barretto que

a análise das origens da sociedade moderna mostra, por sua vez, como foi em torno da escola que se desenvolveram as instituições políticas e sociais do Estado moderno. O mundo ocidental até o século XIII

108 WAISELFISZ, Julio Jacob; MACIEL, Maria. Revertendo violências, semeando futuros: avaliação de impacto do programa abrindo espaços no Rio de Janeiro e em Pernambuco. 3. ed. Brasília: Unesco, 2003. p. 24.

109 ABRAMOVAY, Miriam. Violências nos cotidianos das escolas. In: ABRAMOVAY, Miriam (Org.). Escola e violência. 2. ed. Brasília: Unesco, UCB, 2003. p. 78.

110 AQUINO, Júlio Groppa. Diversidade, igualdade e democracia: a educação em questão. In: CARDOSO, Clodoaldo Meneguello (Org.). Convivência na diversidade: cultura, educação e mídia. Bauru: Unesp; FAAC, 2008. p. 89-105.

111 CAMACHO, Luiza Mitiko Yshiguro. Violência e indisciplina nas práticas escolares de adolescentes: um estudo das realidades de duas escolas semelhantes e diferentes entre si. 2000. 265f. Tese (Doutorado em Educação) - Faculdade de Educação - Universidade de São Paulo [2000]. p. 41.

112 É quando do surgimento das instituições republicanas, posteriormente às revoluções Americana e Francesa, nos anos de 1776 e 1789 que aparecem as escolas. 
conhecera três caminhos de acesso ao poder: nascimento, riqueza e sorteio. Foi, entretanto, através da escola que os pobres ascenderam socialmente no final da Idade Média e início da Idade Moderna. Esse entendimento do papel da educação serviu para que a sociedade liberal e democrática, construída a partir dos séculos XVIII e XIX, entendesse essencial, para que fossem asseguradas a liberdade e a igualdade entre os homens, garantir educação para todos. ${ }^{113}$

Note-se, pois, que historicamente as instituições de ensino podiam ser compreendidas como meios para se alcançar a almejada ascensão social. Uma boa formação e o sucesso escolar demonstravam o mérito e o esforço empreendido pelo aluno, e garantiam a ele uma boa qualificação profissional e, consequentemente, a possibilidade de acumular riquezas patrimoniais.

Contudo, o acesso à educação era bastante complicado e desigual. Nesse sentido, a análise de Dubet sobre a situação francesa pode ser estendida ao que ocorreu em diversos outros países. Assevera, então, o autor que

durante muito tempo o sistema escolar francês foi estruturalmente não igualitário, estando 0 acesso às diferentes carreiras diretamente determinado desde o berço: a cada categoria social um tipo de escola e, consequentemente, um tipo de chance de sucesso. Assim, as crianças do povo iam à escola do povo, as crianças da burguesia ao liceu e alguns indivíduos particularmente "dotados” e aplicados escapavam dessa canalização social das carreiras escolares. ${ }^{114}$

Hoje a escola é muito mais acessível que no passado. ${ }^{115}$ Entretanto, com o início do processo de democratização do ensino, a escolaridade perdeu seu poder de impulso social. Agora, além da escolarização não garantir a inserção no mercado de

113 BARRETTO, Vicente. Educação e violência: reflexões preliminares. In: ZALUAR, Alba (Org.). Violência e educação. São Paulo: Cortez, 1992. p. 58.

114 DUBET, François. As desigualdades multiplicadas. Tradução de Maria do Carmo Duffles Teixeira. Disponível em: <http://www.anped.org.br/rbe/rbedigital/rbde17/rbde17_03_francois_dubet.pdf>. Acesso em: 10 jul. 2013. p. 15.

115 Nos últimos 25 anos, na França, o percentual de filhos de operários que concluíram o ensino médio, fizeram vestibular ou formaram-se na universidade foi multiplicado por mais de quatro. Cf. DUBET, François. As desigualdades multiplicadas. Tradução de Maria do Carmo Duffles Teixeira. Disponível em: <http://www.anped.org.br/rbe/rbedigital/rbde17/rbde17_03_francois_dubet.pdf $>$. Acesso em: 10 jul. 2013. 
trabalho, mormente quando se trata dos postos mais valorizados, ela exclui claramente aqueles que não tiveram acesso a ela ou que não obtiveram êxito em seus estudos.

Ainda quando atingem a educação formal, os filhos das classes populares não alcançam as mesmas condições no mercado de trabalho em cotejo com os colegas economicamente privilegiados. Enquanto estes aproveitam-se das vagas do mercado primário, aqueles conseguem empregos precários e instáveis em um mercado de trabalho dito secundário. ${ }^{116}$ Também, no que se refere às mulheres, ainda que tenham tido a mesma formação dos homens, acessam ao trabalho em piores posições e com salários mais baixos. $^{117}$

Diante desse quadro, Dubet apresenta suas conclusões sobre essa mudança do papel da escola, asseverando que

verificou-se primeiro que a oferta escolar estava longe de ser homogênea, mesmo num sistema republicano, reconhecido como homogêneo: a oferta é de melhor qualidade quando destinada aos mais favorecidos, e isso apesar dos esforços de discriminação positiva. Em seguida, toda uma microssociologia da educação mostrou que as interações escolares e as expectativas recíprocas por parte dos professores e alunos beneficiavam os alunos oriundos das classes médias e superior. Diversos "efeitos” não igualitários foram evidenciados: efeito classe, efeito estabelecimento de ensino, efeito professor. Dessa maneira, a escola acrescenta às desigualdades sociais suas próprias desigualdades. Por muito tempo, pensamos que uma oferta igual pudesse produzir igualdade. Hoje percebemos que não só ela não é realmente igual, mas que sua própria igualdade pode também produzir efeitos não igualitários somados aos efeitos que ela deseja reduzir. Deslizamos assim, sem nos darmos conta,

116 DUBET, François. As desigualdades multiplicadas. Tradução de Maria do Carmo Duffles Teixeira. Disponível em: <http://www.anped.org.br/rbe/rbedigital/rbde17/rbde17_03_francois_dubet.pdf >. Acesso em: 10 jul. 2013.

117 No que se refere especificamente à situação brasileira, a Pesquisa Nacional por Amostra de Domicílios (PNAD), realizada no ano de 2012, constatou que o número de mulheres consideradas desocupadas, ou seja, que estão sem trabalhar, mas à procura de emprego, é de 3,5 milhões (três milhões e quinhentas mil), em um total de 6,1 milhões (seis milhões e seiscentos mil) de pessoas. Ademais, em todas as regiões do país as mulheres recebem salários mais baixos em comparação aos homens. No Nordeste, local onde a diferença é menor, as mulheres recebem $84,42 \%$ do valor auferido pelo sexo oposto, enquanto na região Sul do país, seus salários alcançam apenas 69,27\% do rendimento masculino. Cf. INSTITUTO BRASILEIRO DE GEOGRAFIA E ESTETÍSTICA. Disponível em: $<$ http://www.ibge.gov.br/home/estatistica/populacao/trabalhoerendimento/pnad2011/brasil_defaultpdf_t rabalho.shtm>. Acesso em: 8 nov. 2013. 
para uma filosofia política menos centrada na igualdade que na equidade. $^{118}$

No que se refere à situação nacional,

embora se possa afirmar que, hoje, o acesso e a permanência dos jovens na escola do Brasil se apresentam mais democratizados, por conta da universalização do acesso ao Ensino Fundamental na faixa etária de 7 a 14 anos, que vem ocorrendo desde os anos de 1990, os processos vivenciados pela maioria dos jovens brasileiros e sua estratégias de escolarização ainda expressam as enormes desigualdades a que está submetida essa faixa da população. As trajetórias escolares irregulares, marcadas pelo abandono precoce, as idas e vindas, as saídas e os retornos, podem ser assumidas como importantes sinais de que diferentes grupos de jovens vivem e percorrem o sistema de ensino. ${ }^{119}$

Aquino, analisando as inter-relações entre diversidade, igualdade e democracia no âmbito educacional, assevera que a democratização escolar, que se baseia na tríade acesso, permanência e aprendizagem efetiva, para ser realmente democrática, deve conjugar dois valores precípuos e fundamentais: a igualdade - que se refere ao reconhecimento dos nossos direitos como cidadãos - e a diversidade - que impõe o reconhecimento das diferenças inerentes aos sujeitos.

Assim, para o autor,

democratizar os espaços sociais não significa nivelar os diferentes lugares de seus protagonistas, suplantando a diversidade social/humana que lhe é constitutiva. Ao contrário. É por meio da diferença de seus protagonistas, compartilhada e mutuamente respeitada, que se pode assegurar a possibilidade de uma vida coletiva democrática. ${ }^{120}$

118 DUBET, François. As desigualdades multiplicadas. Tradução de Maria do Carmo Duffles Teixeira. Disponível em: <http://www.anped.org.br/rbe/rbedigital/rbde17/rbde17_03_francois_dubet.pdf>. Acesso em: 10 jul. 2013. p. 13.

119 ANDRADE, Eliane Ribeiro; NETO, Miguel Farah. Juventudes e trajetórias escolares: conquistando o direito à educação. In: ABRAMOVAY, Miriam; ANDRADE, Eliane Ribeiro; ESTEVES, Luis Carlos Gil. Juventudes: outros olhares sobre a diversidade. Brasília: Ministério da Educação, Secretaria da Ação Continuada, Alfabetização e Diversidade; Unesco, 2007. p. 58.

120 AQUINO, Júlio Groppa. Diversidade, igualdade e democracia: a educação em questão. In: CARDOSO, Clodoaldo Meneguello (Org.). Convivência na diversidade: cultura, educação e mídia. Bauru: Unesp; FAAC, 2008. p. 93. 
Também nesse diapasão, afirma Camacho que

os mecanismos de socialização atuantes, hoje, no ambiente escolar estão permitindo a entrada das dificuldades da vida coletiva do país e do mundo, como a própria falta de alteridade, de limites, que gera preconceitos e discriminações, porque a própria escola não está conseguindo imprimir um outro padrão. $\mathrm{Na}$ verdade, ela está simplesmente assimilando, sem filtro, o padrão da vida social coletiva. A consequência desse estado de coisas é a formação de jovens alunos que se mostraram pessoas desprovidas da ideia de alteridade, do espaço democrático, do diálogo, do convencimento ou da persuasão. E, como num círculo vicioso, o resultado disso é a manutenção e até o fortalecimento de uma sociedade autoritária, muito pouco democrática. ${ }^{121}$

Diante disso, a violência escolar pode se manifestar como uma resposta a essa inadequação institucional às demandas da juventude e da sociedade moderna.

Certamente, então, que a conjuntura social reflete-se na escola. Entretanto, menciona-se também que a escola gera a sua própria violência, tendo em vista as peculiaridades de sua estrutura e seu funcionamento.

Assim, defende Charlot que

a escola não é nem um duplo da sociedade, nem um meio totalmente autônomo: é uma instituição social, e, enquanto tal, depende da sociedade; mas é também uma instituição especializada, que se dá finalidades culturais, e que, enquanto tal, reinterpreta sua função social em termos culturais que lhe permitem reivindicar uma autonomia com relação à sociedade. ${ }^{122}$

Também para Paula,

os estabelecimentos de ensino não podem ser vistos apenas como reflexo da opressão, da violência, dos conflitos que acontecem na sociedade. É

121 CAMACHO, Luiza Mitiko Yshiguro. Violência e indisciplina nas práticas escolares de adolescentes: um estudo das realidades de duas escolas semelhantes e diferentes entre si. 2000. 265f. Tese (Doutorado em Educação) - Faculdade de Educação - Universidade de São Paulo [2000]. p. 254-255.

122 CHARLOT, Bernard. A mistificação pedagógica: realidades sociais e processos ideológicos na teoria da educação. 2. ed. Rio de Janeiro: Zahar, 1983. p. 152-153. 
importante argumentar que as escolas também produzem suas próprias formas de violência, no sentido de contrapor a interpretação da escola como um espaço de reprodução, de preservação do que existe. ${ }^{123}$

Note-se, então, que as regras e a disciplina estabelecidas nos projetos pedagógicos de cada escola, a má qualidade do ensino e a conduta autoritária ou omissa de professores e membros do corpo diretivo da instituição são determinantes para a existência da violência escolar.

Assim, com a chegada de mais estudantes às escolas, sobreleva-se o critério de sucesso escolar como modo de distinção e, por conseguinte, de emulação dos alunos com maiores dificuldades de aprendizagem. Logo,

como, desde o nascimento, os indivíduos não eram considerados iguais perante a educação, os insucessos escolares podiam facilmente ser explicados por causas sociais, pela injustiça do sistema e, às vezes, pelas injustiças "naturais", sendo as crianças do povo consideradas menos "dotadas" e menos "ambiciosas" que as da burguesia. A "vantagem” de tal sistema era a não questionar a autoestima dos alunos sem acesso às carreiras mais valorizadas que, aliás, não eram feitas para eles. Cada um podia explicar seus insucessos como consequência de causas sociais, de causas exteriores a ele e a seu próprio valor. [...] Tudo muda na escola democrática de massa que se empenha, e não só formalmente, em oferecer condições iguais de oportunidades. Aos alunos já não são selecionados na entrada do sistema escolar, mas, sim, durante os estudos, em função unicamente de seu desempenho. ${ }^{124}$

Ademais, a supervalorização do sistema de notas estimula uma achacosa disputa entre os estudantes, uma competição em nada saudável para eles.

Em seus diálogos, Adorno e Becker manifestam uma severa crítica contra essa rivalidade estimulada hodiernamente pelas instituições de ensino. Ambos defendem ser ela elemento de uma educação para a barbárie, um princípio contrário à educação humana.

123 PAULA, Carlos Alberto de. A violência na escola. Curitiba: Secretaria de Estado da Educação. Superintendência da Educação. Diretoria de Políticas e Programas Educacionais. Coordenação de Desafios Educacionais Contemporâneos (SEED), 2008. p. 25.

124 DUBET, François. As desigualdades multiplicadas. Tradução de Maria do Carmo Duffles Teixeira. Disponível em: <http://www.anped.org.br/rbe/rbedigital/rbde17/rbde17_03_francois_dubet.pdf>. Acesso em: 10 jul. 2013. p. 15-16. 
E esclarecendo o conceito, assevera Adorno que

com a educação contra a barbárie no fundo não pretendo nada além de que o último adolescente do campo se envergonhe quando, por exemplo, agride um colega com rudeza ou se comporta de um modo brutal com uma moça; quero que por meio do sistema educacional as pessoas comecem a ser inteiramente tomadas pela aversão à violência física. ${ }^{125}$

Ainda podem ser citadas como condicionantes do fenômeno a série, o nível de escolaridade e a idade dos estudantes, tal qual ocorre com o bullying, cuja maior incidência está em uma faixa etária específica, correspondente ao início da adolescência. ${ }^{126}$

O ambiente escolar, ao juntar estudantes de diferentes famílias, com perspectivas de vidas e valores diversos, vê-se obrigado a lidar também com os conflitos interpessoais que surgem nesse contexto.

Assim, "a agressão verbal e a agressão física entre os alunos parecem ter as mesmas origens: são parte dos modelos de relacionamento, dos recursos de resoluções de conflitos e da busca da identidade como um ser social”. ${ }^{127}$

Camacho, em sua tese de doutorado, utilizou-se da metodologia de pesquisa etnográfica, aliada à aplicação de questionários, entrevistas e análise de documentos, em duas escolas localizadas na Grande Vitória, visando a compreender os fenômenos da violência e da indisciplina nesses estabelecimentos. ${ }^{128}$

Os colégios escolhidos receberam os nomes fictícios de Península Sagrada e Pedra Pitanga. O primeiro, particular, frequentado pela elite, era organizado com base em princípios religiosos e ostentador de um projeto pedagógico bastante claro. O segundo,

125 ADORNO, Theodoro W. Educação e emancipação. Tradução de Wolfgang Leo Maar. Rio de Janeiro: Paz e Terra, 1995. p. 165.

126 ABRAMOVAY, Miriam; RUA, Maria das Graças. Violências nas escolas. 4. ed. Brasília: Unesco, 2004.

127 LATERMAN, Ilana. Violência e incivilidade na escola: nem vítimas, nem culpados. Florianópolis: Letras Contemporâneas, 2000. p. 132.

128 CAMACHO, Luiza Mitiko Yshiguro. Violência e indisciplina nas práticas escolares de adolescentes: um estudo das realidades de duas escolas semelhantes e diferentes entre si. 2000. 265f. Tese (Doutorado em Educação) - Faculdade de Educação - Universidade de São Paulo [2000]. 
público, era considerado uma escola de boa qualidade, uma vez que fundado com grande participação da comunidade.

Foram alvo da pesquisa alunos de $5 .^{\mathrm{a}}$ a $8 .^{\mathrm{a}}$ séries, na faixa etária entre 12 e 15 anos, bem como os funcionários dos colégios, nos anos de 1997 e 1998.

Foi realizada ampla abordagem dos discentes, questionando-se, inclusive, sobre os trabalhos de seus genitores, suas atividades de lazer, religião, prática de esportes, entre outros.

A despeito de haver diferenças entre as percepções que os estudantes dos colégios Península Sagrada e Pedra Pitanga tinham sobre a violência e a indisciplina, a autora identificou semelhanças entre os alunos matriculados nos dois estabelecimentos.

Constatou que as práticas de agressão, violência e indisciplina existem na percepção dos alunos das duas escolas; que a indisciplina é praticada como modo de identificação e aprovação do grupo, uma vez que ser indisciplinado implica ser reconhecido pelos pares como corajoso e merecedor de respeito; que ambos os grupos de alunos compreendem a violência como um ato intencional, dirigido a sujeito determinado, com o objetivo de constranger, destruir, desrespeitar ou negar o outro e ambos têm a percepção de serem punidos por seus atos indevidos, embora a autora tenha constatado que o sistema de punições existente na escola privada é muito mais rigoroso, se comparado à pública. $^{129}$

Em ambos os colégios, a pesquisadora verificou que a violência apresentada é interpares, ou seja, praticada entre os estudantes contra eles próprios e que ela tem por fundamento a não aceitação daquele que, por qualquer razão, seja considerado diferente e que, por isso, não se adequa ao grupo.

Nesse diapasão, revela Camacho que a maior parte das agressões verificadas nas escolas "é praticada pela heterofobia, ou seja, pela estranha recusa da diferença, pela

129 CAMACHO, Luiza Mitiko Yshiguro. Violência e indisciplina nas práticas escolares de adolescentes: um estudo das realidades de duas escolas semelhantes e diferentes entre si. 2000. 265f. Tese (Doutorado em Educação) - Faculdade de Educação - Universidade de São Paulo [2000]. 
raiva, pelo desprezo, pela rejeição, enfim, pela não aceitação daquele que o agressor julga diferente de si”. ${ }^{130}$

Referindo-se especificamente ao Colégio Península Sagrada relata a autora que

é muito forte, nesta escola, a rejeição aos diferentes - os pobres, os negros, os não católicos, os gordos, os feitos, os de fora, os com mau desempenho. A cada presença de um diferente, que é minoria, o grupo se fortalece, porque se une para eliminar o "intruso". Para os integrados, esses agrupamentos recebem o nome de "grupo" ou "grupinho". Para os excluídos, esses grupos são as "panelinhas". ${ }^{131}$

Camacho constatou, portanto, que a diferença era sempre a justificativa para o ato violento. Contudo, a alteridade era encarada de maneiras diversas nas duas escolas e desempenhava papel específico em relação às manifestações agressivas.

Na maioria dos casos, na Escola Pedra Pitanga, os agressores eram os diferentes, sendo que suas distinções eram construídas pela adoção de uma imagem ou de um estilo diferente. Todavia, no colégio Península Sagrada, os diferentes eram as vítimas da violência. Nesse caso, a diferença não era criada pelos agredidos, mas existia cultural ou corporalmente.

Ademais, na escola privada, o domínio era exercido pelo belo, enquanto na pública pelos mais fortes e corpulentos, sendo que em ambas o considerado feio era alvo das agressões.

Nas palavras da autora,

das cenas apresentadas observa-se que no Colégio Península Sagrada a diferença é sensível, ou seja, ela é visível na cor da pele, na textura do cabelo, na gordura, na feiura, etc., enquanto que na Escola Pedra Pitanga, em primeiro lugar, a afirmação do diferente em relação ao grupo se dá

130 CAMACHO, Luiza Mitiko Yshiguro. Violência e indisciplina nas práticas escolares de adolescentes: um estudo das realidades de duas escolas semelhantes e diferentes entre si. 2000. 265f. Tese (Doutorado em Educação) - Faculdade de Educação - Universidade de São Paulo [2000]. p. 203.

131 Idem, ibidem, p. 129. Em ambas as escolas constatou-se o poder dos grupos nas relações de sociabilidade dos estudantes, ficando clara a necessidade dos alunos de sentirem-se incluídos, de serem aceitos pelos seus pares. 
por meio da criação de uma marcação de um estilo ou de um visual diferente. Não há, aqui, a diferença sensível e ela é construída. Em segundo lugar, esses diferentes da escola pública pertencem a um grupo e aí podem marcar uma distinção na conduta. ${ }^{132}$

A violência como intolerância diante da diversidade do outro também foi constatada por Leme. ${ }^{133}$

A autora realizou uma pesquisa visando identificar como alunos e diretores de escolas do ensino médio e fundamental de São Paulo percebem o convívio dentro do estabelecimento.

Para tanto, foram entregues questionários em cinquenta e cinco escolas, entre públicas e privadas, sendo que a amostra englobava cinquenta e cinco diretores e quatro mil e vinte e cinco alunos, aos quais se indagava acerca da incidência da violência no estabelecimento, suas causas, a aplicação de regras de disciplina, bem como sobre a qualidade das relações interpessoais estabelecidas.

Apesar de a maioria dos alunos das instituições pesquisadas - cerca de oitenta por cento - acreditar que sua escola valoriza o bom relacionamento entre os alunos, quase metade deles identifica um aumento na quantidade de conflitos nos últimos anos, sendo essa percepção mais aguçada entre os alunos mais jovens, estudantes da 6. ${ }^{\text {a }}$ série do ensino fundamental.

Ainda,

ao opinarem sobre situações de provocação repetida em sites da Internet, 15 a 20\% dos alunos manifestaram no mínimo intolerância, pois culpam a vítima pela agressão sofrida, em função de suas características pessoais, apontadas como motivo legítimo para a ocorrência. Um contingente semelhante acredita que a Internet é um espaço democrático, onde pode

132 CAMACHO, Luiza Mitiko Yshiguro. Violência e indisciplina nas práticas escolares de adolescentes: um estudo das realidades de duas escolas semelhantes e diferentes entre si. 2000. 265f. Tese (Doutorado em Educação) - Faculdade de Educação - Universidade de São Paulo [2000]. p. 247.

133 LEME, Maria Isabel da Silva. Educação, diversidade e igualdade: violência e convívio escolar. In: CARDOSO, Clodoaldo Meneguello (Org.). Convivência na diversidade: cultura, educação e mídia. Bauru: Unesp; FAAC, 2008. p. 107-126. 
ser manifestada qualquer opinião. Estes dados revelam que, para quase metade da amostra estudada, o respeito ao outro não é um valor a ser cultivado, e a liberdade individual de emitir opiniões intolerantes é um direito democrático. Em suma, mostram-se no mínimo mal-informados sobre direitos e deveres, o que precisa ser corrigido com um trabalho de reflexão sobre estes temas na escola. ${ }^{134}$

Note-se, então, que a própria organização escolar não cumpre exclusivamente a função de educar, mas é instrumento capaz de causar uma violência específica desse ambiente de interação social.

Diante do exposto até aqui, constata-se que a violência de um modo geral, bem como a violência escolar, não comportam uma faceta de análise unívoca. Toda a pesquisa que se realiza sobre o tema, portanto, deve ter como foco determinado aspecto de fenômeno, para, a partir daí, conseguir fornecer suficientes explicações para ele.

Assim, no próximo Capítulo, será objeto de análise certa faceta da violência escolar, o denominado bullying.

134 LEME, Maria Isabel da Silva. Educação, diversidade e igualdade: violência e convívio escolar. In: CARDOSO, Clodoaldo Meneguello (Org.). Convivência na diversidade: cultura, educação e mídia. Bauru: Unesp; FAAC, 2008. p. 122. 


\section{Capítulo 2 \\ CONSIDERAÇÕES TEÓRICAS SOBRE O BULLYING ESCOLAR}

\section{$2.1 \quad O$ conceito de bullying}

O conceito de bullying mais bem aceito atualmente e adotado na quase totalidade de estudos sobre o tema é o formulado por Olweus, professor da Universidade de Bergen e primeiro grande estudioso do assunto. Para ele, alguém está sendo vitimado pelo bullying quando exposto, repetidamente e ao longo do tempo, a ações negativas por parte de um ou mais sujeitos, havendo um desequilíbrio de poder na relação estabelecida entre agressor e agredido.

Elucidando a definição formulada, refere o autor que a ação negativa conformadora do bullying ocorre quando alguém inflige ou tenta infligir, intencionalmente, insulto ou desconforto a outrem, basicamente entre aqueles que podem ser identificados como comportamentos agressivos. No que se relaciona à habitualidade da conduta, por sua vez, Olweus entende configurar o bullying a agressão ocorrida “ocasionalmente” ou "habitualmente". 135

Note-se que sempre que acontece um episódio de bullying ocorre uma vitimização, pois a violência é sempre direcionada a alguém. ${ }^{136}$ Tem-se, assim, que uma vítima indefesa é atacada por uma ou mais pessoas, repetidamente, sendo o desequilíbrio de poder entre os sujeitos que são alvos e autores das agressões o facilitador destas.

Trata-se, pois, de uma forma de abuso que tem como componentes fundamentais a repetição e a existência de uma discrepância entre o poder do autor e da vítima, a qual se configura como um abuso de poder sistemático.

\footnotetext{
135 OLWEUS, Dan. Bullying at school. Oxford; Cambridge: Blackwell, 1993.

136 Nesse sentido, vale mencionar que Olweus refere-se ao fenômeno pelas expressões "bullying”, "victimization”, “bully/victim problems”. Cf. OLWEUS, Dan. Bullying at school. Oxford; Cambridge: Blackwell, 1993.
} 
Para Fante e Pedra, esse desequilíbrio é "caracterizado pelo fato de que a vítima não consegue defender-se com facilidade independente da sua idade ou estatura física, nem motivar outros para que a defendam”. ${ }^{137}$

Nas palavras de Shariff,

a grosseria gentil e as provocações se intensificam até chegar ao bullying quando a(s) vítima(s) e o(s) autor(es) deixam de estar de acordo em relação a quando o comportamento deva ser interrompido e quando se estabelece um desequilíbrio de poder entre eles. ${ }^{138}$

O bullying realiza-se, então, mediante xingamentos, colocação de apelidos, socos, hostilizações, exclusão, isolamento, intimidação, enfim, agressões físicas, verbais e psicológicas repetidas contra o outro considerado mais fraco.

Note-se que não se trata de

um comentário ácido ocasional feito por uma pessoa próxima na mesa do café da manhã, um dia ruim com o chefe, crianças brigando com outras enquanto brincam, aprender as duras lições de rivalidade entre irmãos ou a solução de conflitos com colegas. É a crueldade frequente e sistemática, voltada deliberadamente a alguém, por parte de uma ou mais pessoas, com intenção de obter poder sobre o outro ao infligir regularmente sofrimento psicológico e/ou físico. ${ }^{139}$

Nesse diapasão, importante destacar que não são conflitos ou brigas normais que ocorrem entre os sujeitos, e sim verdadeiros atos de intimidação preconcebidos, ameaças, que, sistematicamente, com violência física e/ou psicológica, são impostos a

137 FANTE, Cleo; PEDRA, José Augusto. Bullying escolar: perguntas e respostas. Porto Alegre: Artmed, 2008. p. 40.

138 SHARIFF, Shaheen. Ciberbullying: questões e soluções para a escola, a sala de aula e a família. Tradução de Joice Elias Costa. Porto Alegre: Artmed, 2011. p. 39.

139 MIDDELTON-MOZ, Jane; ZAWADSKI, Mary Lee. Bullying: estratégias de sobrevivência para adultos e crianças. Tradução de Roberto Cataldo Costa. Porto Alegre: Artmed, 2007. 
indivíduos considerados mais fracos, levando-os a uma condição de sujeição, sofrimento psicológico, isolamento e marginalização. ${ }^{140}$

Fica evidente, portanto, a “intencionalidade de magoar alguém, que é vítima e alvo do ato agressivo, enquanto os agressores manifestam tendência a desencadear, iniciar, agravar e a perpetuar situações em que as vítimas estão numa posição indefesa” ${ }^{141}$

Insta salientar que, para a caracterização do bullying, muitos autores defendem a necessidade de que as vítimas sintam-se negativamente afetadas pelas agressões. ${ }^{142}$

Mister que se distingam as agressões eventuais e sem gravidade das habituais, repetitivas e graves, apenas estas sendo consideradas como casos de bullying. Hayden e Blaya, mencionando pesquisa realizada em escolas inglesas, relatam que o termo costuma ser mal empregado, mesmo tendo sido realizadas no país diversas campanhas informativas e planos de intervenção, o que pode comprometer as pesquisas e os dados produzidos sobre o tema. $^{143}$

Ademais, a alarma injustificada sobre o problema causa temor desnecessário e extremamente maléfico aos indivíduos, tendo ainda o condão de motivar políticas públicas desvirtuadas e legislações incriminadoras de emergência.

É em virtude de sua habitualidade e repetição que o bullying pode ser classificado com uma espécie de violência complexa ou frequente. Ele se protrai no tempo, sendo esse fator que o diferencia das demais formas de comportamentos agressivos.

140 COSTANTINI, Alessandro. Bullying: como combatê-lo? Tradução de Eugênio Vinci de Moraes. São Paulo: Itália Nova, 2004.

141 PEREIRA, Beatriz Oliveira. Para uma escola sem violência: estudo e prevenção das práticas agressivas entre crianças. 2. ed. Lisboa: Fundação Calouste Gulbenkian; Fundação para a Ciência e a Tecnologia, 2008. p. 16-17.

142 Nesse sentido: GUARESCHI, Pedrinho A. et al. Bullying: mais sério do que se imagina. 2. ed. Porto Alegre: EDIPUCRS, 2008; FANTE, Cleo; PEDRA, José Augusto. Bullying escolar: perguntas e respostas. Porto Alegre: Artmed, 2008 e CURÇO, Sumaia Fuchs. Prática do bullying nas escolas. In: RODRIGUES, Carolina Cointreiras; AZEVEDO, José Clóvis de; POLIDORI, Marlis Morosini (Orgs.). Os desafios na escola: olhares diversos sobre questões cotidianas. Porto Alegre: Sulina; Universitária Metodista IPA, 2010.

143 HAYDEN, Carol; BLAYA, Catherine. Comportamentos violentos e agressivos nas escolas inglesas. In: DEBARBIEUX, Eric; BLAYA, Catherine (Orgs.). Violência nas escolas: dez abordagens europeias. Tradução de Patrícia Zimbres e Paula Zimbres Brasília: Unesco, 2002. p. 63.102. 
O termo bullying deriva de bully que, como substantivo, tem a significação de valentão, tirano e, como verbo, de brutalizar, tiranizar, amedrontar. ${ }^{144}$

A palavra inglesa tem sido utilizada também nos países de língua portuguesa para designar as agressões sistemáticas, por não ter sido encontrada outra que represente o fenômeno de forma satisfatória. Sobre o assunto Pereira menciona que

a designação do fenômeno na língua portuguesa carece de um conceito que identifique simultaneamente os atributos de personalidade dos sujeitos que dissociamos aos incidentes agressivos e as características que os comportamentos desses mesmos sujeitos assumem [...]. Assim, adoptámos o termo "bullying" associado ao termo agressividade, por não conseguirmos uma tradução fiel, cujo sentido seja a agressão deliberada entre iguais. ${ }^{145}$

Porém, em alguns textos traduzidos para o português, vem sendo usada a palavra intimidação como sinônimo de bullying, apesar de ela não representar todos os comportamentos constantes na citada conduta. ${ }^{146}$

Em outros países o mesmo fenômeno é designado por diferentes expressões, a despeito de a maioria deles utilizar-se da designação inglesa. Na Noruega e na Dinamarca, emprega-se o termo mobbing; hercèlement quotidien na França; prepotenza ou bullismo na Itália; agressionen unter shülern na Alemanha, ijime ${ }^{147}$ no Japão e acoso e amenaza ou intimidación na Espanha.

144 GUARESCHI, Pedrinho A. et al. Bullying: mais sério do que se imagina. 2. ed. Porto Alegre: EDIPUCRS, 2008.

145 PEREIRA, Beatriz Oliveira. Para uma escola sem violência: estudo e prevenção das práticas agressivas entre crianças. 2. ed. Lisboa: Fundação Calouste Gulbenkian; Fundação para a Ciência e a Tecnologia, 2008. p. 16.

146 Nesse sentido ver: DEBARBIEUX, Éric. Cientistas, políticos e violência: rumo a uma nova comunidade científica europeia para lidar com a violência nas escolas? In: DEBARBIEUX, Eric; BLAYA, Catherine (Orgs.). Violência nas escolas: dez abordagens europeias. Tradução de Patrícia Zimbres e Paula Zimbres Brasília: Unesco, 2002, p. 13-33.

147 Para Morita, “a imagem que os japoneses tendem a formar, ao ouvirem a palavra 'Ijime’, não é a da 'violência', associada aos atos de 'intimidação', mas sim a de uma imagem de crueldade, de baixeza e de malevolência, já que essa palavra é intercambiável com a sentença que significa 'intimidar os mais fracos', 'Yowaimono Ijime'. Assim, mesmo quando a intimidação implica violência, as pessoas tendem a pensar primeiramente na fragilidade da vítima e nos danos psicológicos ocasionados por esse ato". Cf. MORITA, Yohji.Violência na escola: uma abordagem japonesa. In: DEBARBIEUX, Éric; BLAYA, 
No que se refere ao abuso de poder sistemático efetivado especificamente no ambiente de trabalho, utiliza-se o termo mobbing para referenciá-lo, sendo este traduzido no Brasil como assédio moral. ${ }^{148}$

O bullying circunscreve-se a diversos contextos em que há interação social, como trabalho, casa, escola, Forças Armadas e prisões. Aparece, assim, em grupos com claras relações de poder e baixa supervisão. ${ }^{149}$ Também se sabe que sua ocorrência está disseminada por todo o território nacional, não se restringindo a determinado grupo socioeconômico menor. ${ }^{150}$

A despeito disso, convém mencionar que mesmo estando presente em muitos ambientes sociais, ele é mais frequente no espaço escolar, até porque estudos apontam que o bullying tende a decrescer à medida que os envolvidos envelhecem e aproximam-se da idade adulta. $^{151}$

\subsection{O bullying nas escolas}

É na escola que a maior parte dos casos de bullying ocorrem, ${ }^{152}$ e também é nesse ambiente em que ele adquire maior importância, uma vez que envolve crianças e adolescentes, cujas personalidades estão ainda em desenvolvimento e que, em decorrência

Catherine (Orgs.). Violência nas escolas e políticas públicas. Tradução de Patrícia Zimbres. Brasília: Unesco, 2002. p. 119.

148 "Assediar moralmente é uma exposição prolongada e repetitiva a condições de trabalho que, deliberadamente, vão sendo degradadas. Surge e se propaga em relações hierárquicas assimétricas, desumanas e sem ética, marcada pelo abuso do poder e manipulações perversas”. Cf. FANTE, Cleo; PEDRA, José Augusto. Bullying escolar: perguntas e respostas. Porto Alegre: Artmed, 2008. p. 76-77.

149 SMITH, Peter K.; SHARP, Sônia. The problem of school bullying. In: SMITH, Peter K.; SHARP, Sônia (Eds.). School bullying: insights and perspectives. Londes; Nova Iorque: Routkedge, 1994. p. 1-19.

150 FANTE, Cleo. Fenômeno bullying: como prevenir a violência nas escolas e educar para a paz. 2. ed. Campinas: Versus, 2005.

151 Nesse sentido: MIDDELTON-MOZ, Jane; ZAWADSKI, Mary Lee. Bullying: estratégias de sobrevivência para adultos e crianças. Tradução de Roberto Cataldo Costa. Porto Alegre: Artmed, 2007 e COSTANTINI, Alessandro. Bullying: como combatê-lo? Tradução de Eugênio Vinci de Moraes. São Paulo: Itália Nova, 2004. Exceção a essa afirmação refere-se apenas ao bullying que se pratica em instituições totais. Cf. COLLINS, Randall. Violence: a micro-sociological theory. Nova Jérsei: Princeton, 2008.

152 Cf. CURÇO, Sumaia Fuchs. Prática do bullying nas escolas. In: RODRIGUES, Carolina Cointreiras; AZEVEDO, José Clóvis de; POLIDORI, Marlis Morosini (Orgs.). Os desafios na escola: olhares diversos sobre questões cotidianas. Porto Alegre: Sulina; Universitária Metodista IPA, 2010. 
disso, têm mais dificuldade em lidar com esse tipo de violência e são mais suscetíveis às suas consequências negativas.

A escola produz um amplo universo simbólico, estimulando configurações de sentidos e de significados e possibilitando a constituição da subjetividade e a construção das identidades. ${ }^{153}$ É nela que crianças e adolescentes "buscam reproduzir sonhos, criar utopias, estabelecer vivências, esperanças e expectativas para o futuro, aceitam e encaram desafios, mitigam valores, tomam atitudes, enfim, exercem aquilo que é inerente a todo cidadão, ou seja, a cidadania”. 154

Assim, “o fenômeno de violência interpessoal no âmbito da convivência entre escolares transcende o fato isolado e esporádico, convertendo-se em um problema escolar de grande relevância, porque afeta as estruturas sociais pelas quais deve ser realizada a atividade educativa”. ${ }^{155}$

Ademais, as manifestações de violência no ambiente escolar comprometem o que deveria ser a própria identidade dela: um lugar de sociabilidade positiva e de aprendizagem ética e crítica, pautadas no reconhecimento da diversidade e na herança do conhecimento acumulado. ${ }^{156}$

Nesse contexto, importante perceber que as violências manifestadas nas escolas, entre as quais se inclui o bullying ali praticado,

têm identidade própria, ainda que se expressem mediante formas comuns, como a violência de fato - que fere e mata - ou como incivilidades, preconceitos, desconsiderações aos outros e à diversidade. Realizam-se,

153 ABRAMOVAY, Miriam; RUA, Maria das Graças. Violências nas escolas. 4. ed. Brasília: Unesco, 2004.

154 NASCIMENTO, Grasiele Augusta Ferreira. Bullying: a violência no âmbito escolar. In: ALKIMIN, Maria Aparecida (Org.). Bullying: visão interdisciplinar. Campinas: Alínea, 2011. p. 16.

155 RUIZ, Rosário Ortega. Violência, agressão e disciplina. In: FERNÁNDEZ, Isabel. Prevenção da violência e solução de conflitos: o clima escolar como fator de qualidade. Tradução de Fulvio Lubisco. São Paulo: Madras, 2005. p. 29.

156 ABRAMOVAY, Miriam; RUA, Maria das Graças. Violências nas escolas. 4. ed. Brasília: Unesco, 2004. 
ainda, no plano simbólico, correndo o risco de naturalizar-se, principalmente quando têm lugar nas ligações entre pares, alunos. ${ }^{157}$

O bullying nas escolas começou a ser estudado sistematicamente a partir da década de 1970, destacando-se os trabalhos de Olweus. Mais tarde, a questão passou a ser pesquisada em toda a Europa, com destaque para França e Grã-Bretanha, onde projetos anti-bullying foram implementados em todas as escolas de seu território. ${ }^{158} \mathrm{Em}$ reconhecimento à extensão e à gravidade do fenômeno, alguns países criaram legislações específicas sobre o assunto, como Finlândia, Suíça, França e Inglaterra. ${ }^{159}$

No Brasil, alguns Estados e Municípios já formularam leis visando à prevenção e ao combate ao bullying nas escolas, como: Lei 14.957, de 16 de julho de 2009 (município de São Paulo); Lei 5.089, de 9 de outubro de 2009 (município do Rio de Janeiro); Lei 13.474 (Rio Grande do Sul); Lei 3.887, de 6 de maio de 2010 (Estado do Mato Grosso do Sul).

Vale mencionar que, a despeito de só começar a ser estudado recentemente, o bullying nas escolas sempre existiu, mas era encarado como parte do processo de crescimento dos jovens, como uma conduta inter-relacional normal.

Foi apenas em meados da década de 1990 que o bullying apareceu efetivamente na agenda educacional. ${ }^{160}$

Além disso, o câmbio na própria etimologia da palavra revela essa mudança de enfoque, uma vez que de um termo utilizado para expressar afeto, ela passou a designar os

ABRAMOVAY, Miriam; RUA, Maria das Graças. Violências nas escolas. 4. ed. Brasília: Unesco, 2004. p. 26.

158 COSTANTINI, Alessandro. Bullying: como combatê-lo? Tradução de Eugênio Vinci de Moraes. São Paulo: Itália Nova, 2004. Vale mencionar que, atualmente, é no Reino Unido que se produzem mais estudos sobre o bullying. Cf. PEREIRA, Beatriz Oliveira. Para uma escola sem violência: estudo e prevenção das práticas agressivas entre crianças. 2. ed. Lisboa: Fundação Calouste Gulbenkian; Fundação para a Ciência e a Tecnologia, 2008.

159 CUBAS, Viviane. Bullying: assédio moral na escola. In: RUOTTI, Caren; ALVES, Renato; CUBAS, Viviane de Oliveira (Orgs.). Violência na escola: um guia para pais e professores. São Paulo: Andhep; Imprensa Oficial do Estado de São Paulo, 2006. p. 188.

160 SMITH, Peter K.; SHARP, Sônia. The problem of school bullying. In: SMITH, Peter K.; SHARP, Sônia (Eds.). School bullying: insights and perspectives. Londes; Nova Iorque: Routkedge, 1994. p. 1-19. 
valentões ou brigões de um grupo e, mais tarde, violência e covardia, acepções que carrega ainda hoje.

Nesse diapasão, revela Shariff que “a transição de um comportamento valentão de um modo geral para um tratamento de real hostilidade destaca uma comparação interessante entre a evolução histórica da palavra e o bullying nas escolas contemporâneas". 161

As pesquisas realizadas por Olweus tornaram-se referência sobre o assunto em todo o mundo e têm servido de base para novos estudos sobre o tema, razão pela qual a apresentação de alguns dos seus resultados não pode ser olvidada.

Na pesquisa coordenada pelo autor, que deu origem a obra Bullying at school, ${ }^{162}$ todas as escolas primárias e secundárias da Noruega foram convidadas a participar e $85 \%$ delas aceitaram o convite.

Constatou-se que aproximadamente $15 \%$ dos alunos das escolas analisadas estavam envolvidos em casos de bullying, sendo em torno de $7 \%$ a porcentagem de perpetradores das agressões e $9 \%$ de suas vítimas. ${ }^{163}$

Algumas das conclusões mais importantes a que chegou a pesquisa demonstram que os meninos envolvem-se mais em casos de bullying do que as meninas; que as vítimas das agressões são geralmente jovens mais fracos e mais novos que os autores; que os meninos praticam, majoritariamente, o bullying direto e as meninas o indireto; que o envolvimento com o bullying, seja no papel de vítima ou de autor, pode durar vários anos; que não há relação direta entre falhas no desempenho escolar e agressividade, a despeito de os envolvidos nas agressões - autores e vítimas - geralmente terem notas mais baixas; que, frequentemente, a única característica física diferenciadora dos autores de bullying e de suas vítimas é a fraqueza destas; que as vítimas típicas costumam ser ansiosas, inseguras, chorar com facilidade e ter problemas de autoestima;

161 SHARIFF, Shaheen. Ciberbullying: questões e soluções para a escola, a sala de aula e a família. Tradução de Joice Elias Costa. Porto Alegre: Artmed, 2011. p. 36.

162 OLWEUS, Dan. Bullying at school. Oxford; Cambridge: Blackwell, 1993.

163 Idem, ibidem. 
que os autores típicos têm uma relação positiva com a violência e são mais impulsivos, dominadores e agressivos com as pessoas; que não há nada que indique que, internamente, os autores das agressões sejam mais inseguros e ansiosos que os demais; que a condição socioeconômica dos indivíduos não interfere na ocorrência do bullying; e que o fenômeno pode ser visto como um componente de uma conduta antissocial e ilegal mais geral do sujeito, enquanto as vítimas estão no nível médio das taxas de criminalidade ou mesmo abaixo delas.

Ademais, no que se refere à escola e seu corpo de funcionários e professores, Olweus observou que ela é realmente o local de interação social onde a maior parte dos casos de bullying ocorre, uma vez que eles tendem a diminuir significativamente entre as pessoas com mais idade; que os docentes fazem muito pouco para fazer cessar as agressões entre os alunos; que não há relação entre o tamanho da classe, da escola ou da cidade onde o estabelecimento de ensino se localiza com a maior ou menor prática das agressões; e que quanto maior a supervisão dos adultos, menos casos de bullying se verificam.

Por sua vez, sobre o comportamento dos pais dos envolvidos com o bullying, o autor ressalta que eles são relativamente inconscientes do problema e que conversam sobre o tema com seus filhos de forma limitada. ${ }^{164}$

Para Shariff, as pesquisas atuais sobre o bullying nas escolas permitem a identificação de algumas particularidades dessas agressões sistemáticas. Entre elas pode-se destacar o desequilíbrio de poder entre autor e vítima, que favorece o primeiro; os autores são, em geral, estimulados pelo grupo de colegas que assistem às agressões, sem nada fazer para cessá-las, bem como pelo dos que o incitam, estimulando-os ativamente; os alvos de bullying costumam ser afastados e isolados pelos demais estudantes em virtude de sua condição de vítima atrair uma atenção negativa de seus colegas; o afastamento do grupo em relação à vítima fortalece o poder dos perpetradores; o comportamento dos autores não é desejado nem solicitado pela vítima; e as ações dos agressores são deliberadas, repetidas e, muitas vezes, implacáveis. ${ }^{165}$

\footnotetext{
164 OLWEUS, Dan. Bullying at school. Oxford; Cambridge: Blackwell, 1993.

165 SHARIFF, Shaheen. Ciberbullying: questões e soluções para a escola, a sala de aula e a família. Tradução de Joice Elias Costa. Porto Alegre: Artmed, 2011.
} 
Ocorrências de bullying também foram identificadas no Japão. Pesquisadores japoneses atribuem esses casos ao exacerbado individualismo característico do período pós-guerra, à competitividade própria da sociedade e das escolas japonesas, bem como à diminuição do papel dos pais na educação de seus filhos.

Para Dumouchel não é possível afirmar que o bullying seja mais comum hoje do que antigamente, e sim que hoje tem se tornado possível ver e falar sobre o tema. ${ }^{166}$

Para ele, as escolas japonesas impõem regras de uniformização dos alunos que acabam tornando-os intolerantes à mínima diferença que possa existir entre eles. Além de impor o uso do uniforme dentro do ambiente escolar, as escolas determinam a aparência dos alunos mesmo fora dela ao proibir os cabelos longos e ao determinar os locais aonde os alunos podem ir desacompanhados de um adulto.

Aliadas a essas regras de indiferenciação, as escolas japonesas estimulam exacerbadamente a competitividade entre os alunos, tendo em vista a dificuldade dos exames de entrada na universidade e a possibilidade de ascensão social que um bom estudo representa no país.

Sendo assim, a instituição escolar japonesa ensina aos estudantes que os resultados escolares são um fator que a sociedade deve observar e respeitar no momento da distribuição das carreiras e vantagens, deixando claro que esses critérios são considerados pelas escolas mais importantes do que as interações entre os pares que nelas se estabelecem.

Nesse sentido, pois, evidencia-se que violência não se relaciona com a função acadêmica da escola, e sim com a escola como instituição de socialização. ${ }^{167}$

166 DUMOUCHEL, Paul. Ijime et La violence de l'indifférenciation dans le Japon moderne. In: MARTINEZ, Marie-Louise; SEKNAADJÉ-ASKÉNAZI, José (Orgs.). Violence et éducation: de la méconnaissance à l'action éclairée. 2. ed. Paris: L’Harmattan, 2002. p. 173-180.

167 Idem, ibidem, p. 173-180. 
No Brasil, o fenômeno é ainda pouco estudado, não existindo dados que permitam identificar a extensão do problema no país. Fato é que, no cotejo com os países europeus, o Brasil está com pelo menos 15 anos de atraso no estudo do tema. ${ }^{168}$

Ao tratar das pesquisas realizadas em âmbito nacional sobre violência nas escolas, Abramovay e Rua destacam que

embora esses estudos ainda sejam incipientes, por focarem em grande maioria situações regionais ou localizadas, os resultados obtidos apontam as principais modalidades de violência, quais sejam: ações contra o patrimônio, tais como as depredações e pichações, na década de 1980, bem como as formas de agressão interpessoal, principalmente entre os próprios alunos, na década de $1990 .{ }^{169}$

Ainda que exíguas, têm sido realizadas no país algumas pesquisas específicas sobre o tema bullying escolar.

Entre os anos de 2002 e 2003 a Associação Brasileira Multiprofissional de Proteção à Infância e à Adolescência (Abrapia) efetivou um estudo com 5.482 alunos matriculados entre o quinto e oitavo ano de nove escolas públicas e duas particulares do município do Rio de Janeiro.

A pesquisa apontou que 40,5\% dos alunos admitiram ter envolvimento direto na prática das agressões sistemáticas, no papel de autor ou de vítima. ${ }^{170}$

Em outro estudo realizado por Fante, entre os anos de 2000 e 2003, com dois mil escolares da cidade de São José do Rio Preto, constatou-se que 49\% dos participantes

168 FANTE, Cleo. Fenômeno bullying: como prevenir a violência nas escolas e educar para a paz. 2. ed. Campinas: Versus, 2005.

169 ABRAMOVAY, Miriam; RUA, Maria das Graças. Violências nas escolas. 4. ed. Brasília: Unesco, 2004. p. 84.

170 OBSERVATÓRIO DA INFÂNCIA. Diga não para o bullying. Disponível em: <www.observatoriodainfancia.com.br/IMG/pdf/doc-100.pdf>. Acesso em: 2 jul. 2012. 
estavam envolvidos de alguma forma com o fenômeno, sendo 22\% no papel de vítimas, $15 \%$ de agressores e $12 \%$ de vítimas agressoras. ${ }^{171}$

Note-se que os índices encontrados nas duas pesquisas são bem mais elevados dos que os encontrados por Olweus. Entretanto, não é possível derivar daí a conclusão de que há mais bullying no Brasil em cotejo com a Noruega, uma vez que a amostragem de estudantes pesquisados aqui é pouco representativa.

De qualquer modo, as tentativas de identificar o problema no Brasil são de grande relevância, já que "há, de um lado, resistência na escola pública, mas sobretudo na particular, em reconhecer, assumir e declarar como a questão da violência aparece no seu cotidiano". ${ }^{172}$

Independentemente da persistência espaçotemporal alcançada pelo problema, mister seja ele elucidado, uma vez que "ao subestimar a extensão quantitativa da violência, corremos o risco de aprisionar suas vítimas na culpa ou no silêncio”. ${ }^{173}$

Também deve-se ter em mente, na esteira do pensamento de Olweus, que a questão do bullying concerne a um dos nossos princípios democráticos fundamentais, o de que cada indivíduo deve ter o direito de não sofrer opressão ou humilhação repetidas, na escola e na sociedade como um todo. ${ }^{174}$

São elementos essenciais ao bullying escolar o poder e a exclusão. O principal objetivo do autor é a humilhação, o isolamento e a exclusão de sua vítima, colocando-a em uma situação de extremo desconforto, ao mesmo tempo que, com essa atitude, mostra para o grupo sua força e reafirma sua liderança.

171 FANTE, Cleo. Fenômeno bullying: como prevenir a violência nas escolas e educar para a paz. 2. ed. Campinas: Versus, 2005.

172 SPOSITO, Marília Pontes. Violência e escola: as múltiplas faces de uma relação. In: PACHECO, Elza Dias (Org.). O cotidiano infantil violento: marginalidade e exclusão social. São Paulo: Lapic: L’Editora: Fapesp, 2007. p. 54.

173 DEBARBIEUX, Éric. Cientistas, políticos e violência: rumo a uma nova comunidade científica europeia para lidar com a violência nas escolas? In: DEBARBIEUX, Eric; BLAYA, Catherine (Orgs.). Violência nas escolas: dez abordagens europeias. Tradução de Patrícia Zimbres e Paula Zimbres Brasília: Unesco: 2002. p. 24.

174 OLWEUS, Dan. Bullying at school. Oxford; Cambridge: Blackwell, 1993. 
Conforme já se mencionou, casos de bullying ocorrem preponderantemente nas escolas, uma vez que a diversidade e a frequência das interações que lá acontecem podem constituir oportunidades de vitimação. Estas se devem a três fatores principais: a população que a frequenta, a supervisão realizada por ela e a organização das rotinas dentro do espaço escolar. $^{175}$

No que se refere ao capital social da instituição, os estudos têm demonstrado que não há diferenças significativas entre os índices de prática de bullying em escolas particulares ou públicas. ${ }^{176}$ De qualquer modo,

a questão escola pública/escola privada tem repercussões importantes, não apenas porque uma vive do setor público e outra da riqueza privada, mas porque tende a organizar guetos em uma única classe social. Entre outras coisas, a guetização representa uma microssociedade que aparentemente prefigura a sociedade exterior mas que não corresponde à realidade, criando um contexto social falso. ${ }^{177}$

A maior incidência de bullying verifica-se entre alunos do $6 .^{\circ}$ ao $9 .^{\circ}$ ano, no período inicial da adolescência. ${ }^{178}$ Para Dubet, “o ginásio (collège) é o momento em que a vida adolescente se confronta com a escola, e não é surpreendente que aí as violências escolares ocorram com mais frequência”. ${ }^{179}$

Na maioria dos países pesquisados, o pátio onde se desenvolve o recreio é o local em que, precipuamente, costumam ocorrer as agressões. No Brasil, entretanto, tem-se

175 FERREIRA, Pedro Moura. Vitimação juvenil. Lisboa: Centro de Estudos Judiciário, 1997.

176 Nesse sentido ver: TOGNETTA, Luciene Reguna Paulino; VINHA, Telma Pileggi. Estamos em conflito: eu, comigo e com você! Uma reflexão sobre o bullying e suas causas afetivas. In: CUNHA, Jorge Luiz da; DANI, Lúcia Salete Celich (Orgs.). Escola, conflitos e violências. Santa Maria: UFSM, 2008; FANTE, Cleo. Fenômeno bullying: como prevenir a violência nas escolas e educar para a paz. 2. ed. Campinas: Versus, 2005 e SMITH, Peter K.; SHARP, Sônia. The problem of school bullying. In: SMITH, Peter K.; SHARP, Sônia (Eds.). School bullying: insights and perspectives. Londes; Nova Iorque: Routkedge, 1994. p. 1-19.

177 CASTRO, Lola Aniyar de. Criminologia da libertação. Tradução de Sylvia Moretzsohn. Rio de Janeiro: Revan, 2005. p. 161.

178 FANTE, Cleo; PEDRA, José Augusto. Bullying escolar: perguntas e respostas. Porto Alegre: Artmed, 2008. O grupo formado por alunos de faculdade é mais aberto e heterogêneo em cotejo com os escolares, o que ajuda a reduzir a ocorrência do bullying nesse ambiente. Cf. COLLINS, Randall. Violence: a micro-sociological theory. Nova Jérsei: Princeton, 2008.

179 DUBET, François. A formação dos indivíduos: a desinstitucionalização. Disponível em: <www.lcqribeiro.pro.br/wp-content/uploads/2011/03/A-forma\%C3\%A7\%C3\%A3o-dosindiv\%C3\%ADduos-DubetFran\%C3\%A7ois.pdf>. Acesso em: 10 jul. 2013. p. 3. 
demonstrado a prevalência dessa prática nas salas de aula, especialmente durante os intervalos para troca de professores. ${ }^{180}$

De todo modo, note-se que as agressões costumam ocorrer em momentos de ausência ou escassa presença de responsáveis pelos alunos. Isso sugere que a supervisão realizada pelos professores e funcionários da escola é extremamente eficaz na diminuição da violência.

Assim, a atuação da escola é determinante para evitar a ocorrência de casos de bullying em seu ambiente, mas o que se constata, até o momento, é que ela não está atenta nem preparada para lidar com o problema.

Nesse sentido relatam Tognetta e Vinha que,

do ponto de vista psicológico, é verdade que um caso de bullying diz respeito ao que é particular. Talvez essa seja a explicação maior para que a escola tenda a "fechar os olhos" para a problemática, já que costuma tratar do que é público. Entretanto, tal informação parece revelar certa dicotomia entre o que a escola "deseja” e o que realmente "faz". ${ }^{181}$

Na verdade, é “o valor de si construído em suas relações com pares e com suas autoridades (professores, pais e outros adultos) que determinará as condutas de agressores ou vítimas de bullying”. 182

180 NOGUEIRA, Rosana Maria César Del Picchia de Araújo. Violências nas escolas e juventude: um estudo sobre bullying escolar. 2007. 257f. Tese (Doutorado em Educaçao) - Faculdade de Educação Pontifícia Universidade Católica de São Paulo, [2007].

181 TOGNETTA, Luciene Reguna Paulino; VINHA, Telma Pileggi. Estamos em conflito: eu, comigo e com você! Uma reflexão sobre o bullying e suas causas afetivas. In: CUNHA, Jorge Luiz da; DANI, Lúcia Salete Celich (Orgs.). Escola, conflitos e violências. Santa Maria: UFSM, 2008. p. 204.

182 TOGNETTA, Luciene Reguna Paulino; VINHA, Telma Pileggi. Estamos em conflito: eu, comigo e com você! Uma reflexão sobre o bullying e suas causas afetivas. In: CUNHA, Jorge Luiz da; DANI, Lúcia Salete Celich (Orgs.). Escola, conflitos e violências. Santa Maria: UFSM, 2008. p. 214. Guareschi identifica um fenômeno que chama de bullying pedagógico ou didático. Refere-se à maneira como se ensina na escola, adotando-se uma teoria da educação baseada no autoritarismo, uma relação vertical na qual o professor é o sujeito que tudo sabe e o aluno, abaixo dele, é o que tem que aprender tudo, pois nada sabe. Cf. GUARESCHI, Pedrinho A. O bullying está dentro da nossa sociedade, na própria família, que usa práticas pedagógicas verticais autoritárias. Criança e consumo - entrevistas violência. Instituto Alana - Projeto Criança e Consumo: Coordenação editorial 2PRÓ Comunicação, 2011. p. 6-15. 
Entretanto, é comum o corpo técnico da escola ter dificuldade em identificar o fenômeno, que não o atinge diretamente, tendo ainda em vista que tal comportamento "é facilmente confundido com brincadeiras e em geral ocorre nas áreas de recreação, nos corredores e hoje, com maior frequência, no ciberespaço (e-mail, mensagem de texto, sites), longe dos olhos vigilantes dos professores ou outros supervisores”. ${ }^{183}$ E, portanto, eles “silenciam ou se omitem diante de situações que revelam preconceitos, discriminação, desrespeito ou intolerância”. 184

\section{Diante disso Nogueira reflete que}

talvez nossos professores/escola não saibam distinguir brincadeiras próprias da idade de condutas violentas. Acreditamos que isso ocorra, por dois motivos: primeiro, os professores na sua formação acadêmica e nos cursos de capacitação são treinados com técnicas que os habilitam apenas para o exercício de suas disciplinas, não sendo valorizadas as necessidades de eles lidarem com o afeto e com esses conflitos; segundo, devido a suas posturas de autoritarismo e intimidação na tentativa de obter controle e poder diante do grupo da classe, eles corrigem o comportamentos dos alunos, depreciando-os na frente dos colegas, discriminando-os e ameaçando-os. ${ }^{185}$

A escola deve mostrar-se atenta aos problemas vivenciados pelos alunos e não minimizá-los. Sua atitude acolhedora e democrática, que se reflete na forma como enfrenta os conflitos, insita no aluno uma confiança que o estimula a socorrer-se dela quando algo de errado ocorre. Quanto mais parecido o estabelecimento for com uma instituição total mais casos de bullying ocorrem em seu seio. ${ }^{186}$

Idealmente, "a escola é local de aprendizagem de valores pela reflexão, através dos conteúdos desenvolvidos em sala de aula, mas também se torna espaço importante para a prática de valores, principalmente os relacionados à tolerância e ao respeito pela

183 SHARIFF, Shaheen. Ciberbullying: questões e soluções para a escola, a sala de aula e a família. Tradução de Joice Elias Costa. Porto Alegre: Artmed, 2011. p. 35.

184 SILVA, Clemildo Anacleto da. Educação, tolerância e direitos humanos: a importância do ensino de valores na escola. Porto Alegre: Sulina; Universitária Metodista, 2009. p. 87.

185 NOGUEIRA, Rosana Maria César Del Picchia de Araújo. Violências nas escolas e juventude: um estudo sobre bullying escolar. 2007. 257f. Tese (Doutorado em Educaçao) - Faculdade de Educação Pontifícia Universidade Católica de São Paulo, [2007]. p. 220.

186 COLLINS, Randall. Violence: a micro-sociological theory. Nova Jérsei: Princeton, 2008. 
diversidade”. ${ }^{187}$ Assim, “além do debate, da discussão e da reflexão, é necessário que a própria escola seja um exemplo de ética, de tolerância, de inclusão, da valorização, da diversidade". ${ }^{188}$

Contudo, “ao contrário do que se imagina, muitas vezes, se constitui em espaço de prática, divulgação e pregação de intolerância”. ${ }^{189}$

Nesse diapasão, David assevera que a violência e a escola estão relacionadas de três maneiras, fundamentalmente. Em primeiro lugar, as escolas podem originar a delinquência; em segundo, podem colaborar na sua prevenção; e, finalmente, podem combater a delinquência por intermédio de seu currículo e das atividades que desenvolvem. E, para ele, a principal faceta entre esses conteúdos é o que relaciona a escola como produtora da violência. Nesse sentido, revela que a escola o faz quando não mantém o interesse dos estudantes, determina o fracasso escolar e fomenta experiências de frustração. $^{190}$

Adorno em seu livro de diálogos com Hellmut Becker intitulado Educação e emancipação problematiza o conceito de educação nos dias atuais. ${ }^{191}$

Para Adorno, houve um tempo em que a palavra educação fazia sentido por si só, são necessitava de nenhuma explicação. Em contrapartida, hodiernamente, o termo não mais é compreensível por si mesmo, sendo mister que se pergunte educação para quê?

Educação para emancipação. Esse objetivo primordial da ação de educar coincide com a ideia de educação para a experiência, ou seja, no sentido de experienciar o não eu no outro, a fim de evitar que episódios como o de Auschwitz se repitam.

187 SILVA, Clemildo Anacleto da. Educação, tolerância e direitos humanos: a importância do ensino de valores na escola. Porto Alegre: Sulina; Universitária Metodista, 2009. p. 15-16.

188 Idem, ibidem, p. 159.

189 Idem, p. 81.

190 DAVID, Pedro R. Sociología Criminal Juvenil. 6. ed. Buenos Aires: Lexis Nexis, 2003.

191 ADORNO, Theodoro W. Educação e emancipação. Tradução de Wolfgang Leo Maar. Rio de Janeiro: Paz e Terra, 1995. 
A educação emancipatória, segundo o autor, é fundamental na consecução de uma sociedade democrática. Logo, "uma democracia com o dever de não apenas funcionar, mas operar conforme seu conceito, demanda pessoas emancipadas. Uma democracia efetiva só pode ser imaginada enquanto uma sociedade de que é emancipado”. ${ }^{192}$

Ainda segundo Adorno, educar não é modelar pessoas ou simplesmente transmitir conhecimentos, e sim produzir uma consciência verdadeira, imbuída de questionamentos da psicologia profunda. É a assunção de uma função política da educação.

Desse modo, assevera o autor que

a educação seria impotente e ideológica se ignorasse o objetivo de adaptação e não preparasse os homens para se orientarem no mundo. Porém, ela seria igualmente questionável se ficasse nisto, produzindo nada além de well adjusted people, pessoas bem ajustadas, em consequência do que a situação existente se impõe precisamente no que tem de pior. ${ }^{193}$

É, pois, “na educação que devemos colocar nossas maiores esperanças, sem, contudo esquecer, que uma educação autoritária, repressiva, carente de afeto pode levar às mesmas barbáries que a extrema ignorância”. 194

Assim, apresentando um ideal de educação moral, condizente com a complexidade e pluralidade das sociedades modernas, Cenci destaca ter ela quatro desafios precípuos. Trata-se de combater a lógica privada presente nas relações pedagógicas e fortalecer o papel do educador; avigorar o escalonamento de valores morais; conceber e orientar a escola como espaço de mediação para o espaço público; bem como educar para a

192 ADORNO, Theodoro W. Educação e emancipação. Tradução de Wolfgang Leo Maar. Rio de Janeiro: Paz e Terra, 1995. p. 141-142.

193 Idem, ibidem, p. 143.

194 NOVINSKY, Anita Waingort. Para um novo conceito de educação. In: CARDOSO, Clodoaldo Meneguello (Org.). Convivência na diversidade: cultura, educação e mídia. Bauru: Unesp; FAAC, 2008. p. 83. 
vivência de valores universais, contribuindo, assim, para a passagem do âmbito privado para o público. ${ }^{195}$

\subsubsection{Formas de manifestação}

A violência ínsita ao bullying pode ser manifestada mediante diversos comportamentos. Primeiramente, ela pode ser praticada direta ou indiretamente.

O bullying direto pressupõe a ocorrência de ataques explícitos, realizados por palavras ou agressões físicas, a uma ou mais vítimas. O indireto, por sua vez, impõe o isolamento e exclusão social ao sujeito que é seu alvo.

Diversos comportamentos podem ser considerados formas de manifestação do bullying, quando cumulados com os requisitos da repetição, da habitualidade e do desequilíbrio de poder, não sendo possível elencar a todos ou dividi-los de acordo com suas especificidades. Precipuamente, as agressões podem ser englobadas nas categorias físicas, verbais, psicológicas e virtuais.

As agressões físicas são atos que violam a integridade física da vítima, como bater, chutar, empurrar e beliscar.

As agressões verbais incluem insultos, xingamentos, colocação de apelidos, piadas ofensivas, entre outras.

O bullying psicológico "geralmente envolve infligir um sofrimento mental de modo que os alvos temam por sua segurança física, ou destruir-lhes a autoestima e autoconfiança”. ${ }^{196}$ Ele pode ser praticado, por exemplo, por meio dos atos de humilhar, ridicularizar, excluir, isolar, desprezar, difamar e discriminar a vítima.

195 CENCI, Angelo Vitório. Subjetividade, individualismo e formação moral no contexto de sociedades complexas e moralistas. In: TREVISAN, Amarildo Luiz; TOMAZETTI, Elisete Medianeira; ROSSATTO, Noeli Dutra (Orgs.). Diferença, cultura e educação. Porto Alegre: Sulina, 2010.

196 SHARIFF, Shaheen. Ciberbullying: questões e soluções para a escola, a sala de aula e a família. Tradução de Joice Elias Costa. Porto Alegre: Artmed, 2011. p. 48. 
Virtuais ou ciberbullying, por sua vez, são as agressões praticadas pela rede mundial de computadores ou por meio de outras tecnologias da comunicação e da informação, como os telefones celulares.

Entre todas as formas de agressões apresentadas, as verbais costumam ser as mais utilizadas pelos perpetradores do bullying.

Ortega, ao descrever estudo que realizou juntamente com Smith sobre relações interpessoais nas escolas nos anos de 1991 e 1992, verificou que insultos, xingamentos e intimidação, práticas verbais de bullying, foram as formas de maus-tratos mencionadas pelos alunos com maior frequência, seguidas de ameaça e maus-tratos indiretos. A violência física apareceu em quarto lugar e, em quinto, a exclusão e o isolamento social. ${ }^{197}$

No Levantamento da População Estudantil de Nuremberg, datado de 1994, xingamentos ou ofensas verbais dirigidos a colegas também apareceram como o ato mais comum de violência ou transgressão, tendo sido citado em 82,9\% dos casos pelos meninos e $74,1 \%$ pelas meninas. ${ }^{198}$

Em território nacional, a já mencionada pesquisa realizada pela Abrapia apontou a colocação de apelidos como o tipo de bullying de maior ocorrência, tendo sido citado por $50,4 \%$ dos meninos e $64 \%$ das meninas. ${ }^{199}$

Nogueira encontrou em seu estudo que o tipo de bullying praticado muda à medida que os alunos vão ficando mais velhos. Enquanto nas séries iniciais ele costuma ser direto, entre os alunos com mais idade passa a ser mais indireto, por meio de ameaças,

197 ORTEGA, Rosario. O projeto de Sevilha contra a violência nas escolas: um modelo de intervenção educacional de natureza ecológica. In: DEBARBIEUX, Eric; BLAYA, Catherine (Orgs.). Violência nas escolas: dez abordagens europeias. Tradução de Patrícia Zimbres e Paula Zimbres Brasília: Unesco, 2002, p. 197-222.

198 FUNK. Walter. A violência nas escolas alemãs: situação atual. In: DEBARBIEUX, Eric; BLAYA, Catherine (Orgs.). Violência nas escolas: dez abordagens europeias. Tradução de Patrícia Zimbres e Paula Zimbres Brasília: Unesco, 2002. p. 131-152.

199 OBSERVATÓRIO DA INFÂNCIA. Diga não para o bullying. Disponível em: <www.observatoriodainfancia.com.br/IMG/pdf/doc-100.pdf>. Acesso em: 2 jul. 2012. 
difamações, discriminações, colocação de apelidos ofensivos, bem como pela exclusão do aluno do grupo. ${ }^{200}$

O sexo dos atores tem repercussão no tipo de agressão praticada. Os meninos envolvem-se mais do que as meninas em casos de bullying, sendo que costumam praticar mais as formas físicas de agressões em detrimento das demais. Elas, de modo diverso, costumam utilizar-se do bullying psicológico ou indireto, que pressupõe fazer comentários fingidos e maldosos, espalhar mentiras e fofocas, mais do que proferir agressões verbais abertamente.

Simmons, ao descrever o bullying entre as meninas, relata que

para se esquivarem da desaprovação social, as meninas se escondem sob uma fachada de doçura para se magoarem mutuamente em segredo. Elas passam olhares dissimulados e bilhetes, manipulam silenciosamente o tempo todo, encurralam-se nos corredores, dão as costas, cochicham e sorriem. $^{201}$

Elas muitas vezes falam mal de outras para tentarem se destacar no grupo, para serem aceitas e evitarem o isolamento. É ainda comum a eleição de uma estudante para ser perseguida pelas demais.

A compreensão da intensidade do relacionamento entre as meninas é fundamental para se entender as agressões por elas praticadas. Elas temem ficar sozinhas, isolarem-se do grupo, e por isso, muitas vezes, preferem alimentar relacionamentos destrutivos a afastarem-se das colegas. Também por isso que grande parte dos casos de bullying ocorre no seio de suas amizades. As autoras, portanto, costumar ser amigas de suas vítimas.

É a obediência a modelos culturais que justifica a diferença nos estilos das agressões praticadas. Fato é que “as adolescentes não aprendem a expressar a raiva de

200 NOGUEIRA, Rosana Maria César Del Picchia de Araújo. Violências nas escolas e juventude: um estudo sobre bullying escolar. 2007. 257f. Tese (Doutorado em Educação) - Faculdade de Educaçao Pontifícia Universidade Católica de São Paulo, [2007].

201 SIMMONS, Rachel. Garota fora do jogo: a cultura oculta da agressão nas meninas. Tradução de Talita M. Rodrigues. Rio de Janeiro: Rocco, 2004. p. 33. 
forma direta. Ao contrário do que ocorre com os rapazes, não é permitido que elas briguem fisicamente com suas inimigas. Expressam então a raiva por meio de falsidade e zombarias". 202

Elas se esforçam para ser alguém que elas não são. Mutilam suas vontades e desejos em nome da aceitação grupal.

Nas palavras de Pipher, “a adolescência é a época em que as meninas sofrem uma pressão social para pôr de lado seus eus autênticos e demonstrar apenas uma parte dos seus dons”. 203

Assim, as agressões ao seu próprio eu e às colegas acabam sendo comuns nos relacionamentos entre as meninas. Note-se, porém, que esse tipo de agressividade, muitas vezes, passa despercebido pelos olhos dos adultos, alheios à relação entre elas, e, por isso, não é identificado como um ato de violência.

\section{Para Simmons,}

um mundo que reconhece a cultura oculta da agressão das meninas lhes autorizaria não só a negociar conflitos, mas também a definir os relacionamentos de maneiras novas e mais saudáveis. As meninas aprenderiam que o relacionamento é uma opção, não uma obrigação. Elas compreenderiam o relacionamento como uma parceria escolhida, na qual cuidado e conflito são confortavelmente trocados. ${ }^{204}$

\subsubsection{Os papéis assumidos}

O bullying pressupõe a participação de, ao menos, dois indivíduos, o autor e a vítima das agressões. Entretanto, geralmente há um grande número de pessoas envolvidas, de forma indireta, conformada pelo público, os espectadores da violência.

202 PIPHER, Mary Bray. O resgate de Ofélia: o drama da adolescente no mundo moderno. Tradução de Wáldea Barcellos. São Paulo: Martins Fontes, 1998. p. 86.

203 Idem, ibidem, p. 11.

204 SIMMONS, Rachel. Garota fora do jogo: a cultura oculta da agressão nas meninas. Tradução de Talita M. Rodrigues. Rio de Janeiro: Rocco, 2004. p. 306. 
Os autores de bullying utilizam-se de suas habilidades sociais - sua capacidade de liderança e persuasão - para manipular e dominar o outro. Costumam ser agressivos não apenas com os pares, mas com todos os sujeitos com os quais se relacionam.

São pessoas habituadas a usar recursos violentos para alcançar seus objetivos, que podem ser ganhos sociais ou materiais. Valem-se, pois, de sua força física e habilidade psicoemocional para atemorizar os mais fracos. ${ }^{205}$

Ademais, são impulsivos e sentem necessidade de submeter o outro ao seu poder. No caso dos meninos, costumam ser mais fortes fisicamente que suas vítimas.

Entretanto, são pessoas bem aceitas no grupo, com bastante empatia social, e que têm um grande número de amigos.

Na pesquisa realizada por Nogueira em duas escolas da cidade de São Paulo, uma pública e outra particular, a autora constatou que os "alunos-autores eram bons alunos, com raras exceções, eram simpáticos, populares entre o grupo de alunos e poucos mostraram condutas antissociais, muito pelo contrário, eram extremamente amáveis, populares e extrovertidos”. ${ }^{206}$

Para Collins, atualmente, o bullying faz parte do processo de construção do status nas escolas secundárias dos Estados Unidos, sendo que os agressores utilizam-se desse recurso violento para ascender no ranking dos alunos populares. ${ }^{207}$

Nesse diapasão Funk acrescenta, tratando das escolas alemãs, que na opinião dos estudantes a utilização da violência é recurso usado por eles para obtenção de atenção

205 FANTE, Cleo; PEDRA, José Augusto. Bullying escolar: perguntas e respostas. Porto Alegre: Artmed, 2008.

206 NOGUEIRA, Rosana Maria César Del Picchia de Araújo. Violências nas escolas e juventude: um estudo sobre bullying escolar. 2007. 257f. Tese (Doutorado em Educação) - Faculdade de Educaçao Pontifícia Universidade Católica de São Paulo, [2007]. p. 212.

207 COLLINS, Randall. Violence: a micro-sociological theory. Nova Jérsei: Princeton, 2008. 
e estima. Ou seja, eles se utilizam da agressão ao outro para se exibir e tentar ser aceito pelo grupo. $^{208}$

A agressividade, bem como outros componentes da conduta e da personalidade dos indivíduos, tem múltiplas causas, não sendo possível apontar um único fator como seu desencadeador. Sabe-se, porém, que a criação familiar pode ser uma das fontes da agressividade desses jovens. Uma criação familiar dominadora ou exacerbadamente rígida pode estimular respostas violentas dos indivíduos.

Nesse sentido Guareschi ressalta que “esta agressividade pode ainda ser associada ao tipo de aprendizado que a família proporciona, incutindo direta ou indiretamente uma espécie de intolerância ao diferente”. 209

Em relação às vítimas, elas costumam ser diferenciadas entre vítimas típicas, agressoras e provocadoras.

Olweus explica que as características das vítimas típicas, denominadas por ele vítimas passivas ou submissas, são relativamente claras. Trata-se de sujeitos mais ansiosos, inseguros, sensíveis e quietos que os demais, com poucos ou nenhum amigo. Têm uma visão negativa de si próprios e geralmente reagem às agressões chorando ou se retraindo. ${ }^{210}$

Fisicamente, são bem mais magros ou gordos do que os colegas, fazem uso de óculos, aparelhos dentários ou de algum outro elemento diferenciador e não são considerados bonitos.

Até o sucesso escolar do aluno atrai reações negativas por parte dos autores do bullying. Assim, menciona Shariff que

208 FUNK. Walter. A violência nas escolas alemãs: situação atual. In: DEBARBIEUX, Eric; BLAYA, Catherine (Orgs.). Violência nas escolas: dez abordagens européias. Tradução de Patrícia Zimbres e Paula Zimbres Brasília: Unesco, 2002. p. 131-152.

209 GUARESCHI, Pedrinho A. et al. Bullying: mais sério do que se imagina. 2. ed. Porto Alegre: EDIPUCRS, 2008. p. 65-66.

210 OLWEUS, Dan. Bullying at school: long-term outcomes for the victims an effective school-based intervention program. In: HUESMANN, L. Rowel (Ed.). Aggressive behavior: current perspectives. Nova Iorque: Plenum, 1994. 
o que é surpreendente é que alunos talentosos, ou aqueles com uma forte ética para o trabalho escolar, parecem atrair o bullying - possivelmente pelo fato de os jovens subconscientemente desejarem alcançar bons resultados acadêmicos quando percebem que isso traz sucesso profissional e status social. ${ }^{211}$

Também, crianças com necessidades especiais são altamente suscetíveis ao bullying, uma vez que por terem, porventura, dificuldades de fala ou mobilidade, tornam-se mais vulneráveis às agressões. ${ }^{212}$

O componente familiar também tem relevância aqui, já que as vítimas geralmente são criadas por famílias superprotetoras que não lhes dão praticamente nenhuma autonomia.

Os perseguidos são, portanto, “os estranhos, os nerds, os que têm sotaque, jeito efeminado ou sensível, no caso dos meninos, ou masculinizado e grosseiro, no caso das meninas, ou aqueles que são diferentes da maioria dos alunos”. 213

Nesse sentido, relatam Tognetta e Vinha que os

alvos de bullying se isolam; são, na maioria das vezes, tímidos, retraídos, melancólicos e [...] têm sempre uma característica que se diferencia dos outros, aos olhos do grupo social em que fazem parte, seja a estatura física, seja a aparência, a maneira como se comportam. ${ }^{214}$

Logo, as vítimas típicas costumam serem socialmente mais frágeis do que seus colegas.

Assim,

211 SHARIFF, Shaheen. Ciberbullying: questões e soluções para a escola, a sala de aula e a família. Tradução de Joice Elias Costa. Porto Alegre: Artmed, 2011. p. 44-45.

212 Idem, ibidem.

213 FANTE, Cleo; PEDRA, José Augusto. Bullying escolar: perguntas e respostas. Porto Alegre: Artmed, 2008. p. 37.

214 TOGNETTA, Luciene Reguna Paulino; VINHA, Telma Pileggi. Estamos em conflito: eu, comigo e com você! Uma reflexão sobre o bullying e suas causas afetivas. In: CUNHA, Jorge Luiz da; DANI, Lúcia Salete Celich (Orgs.). Escola, conflitos e violências. Santa Maria: UFSM, 2008. p. 201. 
aqueles que sucessivamente atacam o fraco - abusadores domésticos, autores de bullying, ladrões violentos - aprenderam que essa fraqueza não é somente uma condição física. Não é simplesmente o problema de algumas pessoas serem menores ou menos musculosas que as outras. Vítimas são geralmente fracas em um sentido social: ininterruptamente, como pessoas de baixo status, socialmente isoladas, aquelas que reprimem a humilhação que sofrem e adaptam-se aos seus tormentos, ou que lutam contra eles de formas inefetivas. ${ }^{215}$

As citadas características das vítimas fazem com que elas se sintam incapacitadas para reagir diante da violência que sofrem - razão pela qual, muitas vezes, resistem em continuar a frequentar as aulas ou abandonam os estudos - ou ainda, em alguns casos, os sentimentos negativos acumulados durante as agressões fazem com que elas tenham reações extremadas, como é o caso das vítimas agressoras.

As vítimas agressoras são aquelas que são ou foram vitimizadas e acabam por reproduzir esse tratamento com outra pessoa mais vulnerável do que ela, sendo, por vezes, capazes de cometer atos extremos de vingança, como o assassinato de seus algozes.

As grandes tragédias relacionadas ao bullying, em que ex-alunos entram em suas antigas escolas dispostos a matar e morrer, envolvem esse tipo de vítima.

A vítima provocadora, por sua vez, é aquela que ao importunar alguns alunos atrai reações negativas contra si, com as quais não consegue lidar com eficiência.

Na descrição de Nogueira, o aluno-alvo provocador "tem um gênio forte, ruim, difícil; ele pode ser hiperativo, inquieto e mesmo dispersivo e ofensor. Normalmente é caracterizado pelos alunos como irritante e geralmente causa tensões na classe ou no ambiente em que se encontra”. 216

215 COLLINS, Randall. Violence: a micro-sociological theory. Nova Jérsei: Princeton, 2008. p. 188-189.

216 NOGUEIRA, Rosana Maria César Del Picchia de Araújo. Violências nas escolas e juventude: um estudo sobre bullying escolar. 2007. 257f. Tese (Doutorado em Educação) - Faculdade de Educaçao Pontifícia Universidade Católica de São Paulo, [2007]. p. 211. 
Os espectadores, últimos sujeitos envolvidos na dinâmica do bullying, exercem papel fundamental nas agressões, seja não se insurgindo contra elas ou mesmo as incitando mediante palavras e risos de estímulo ao agressor.

Geralmente tal inação se deve ao temor de serem os próximos alvos. Assim, os espectadores, em sua maioria, preferem o silêncio a solidarizar-se com o colega, preferem manter-se no ostracismo a ganhar visibilidade ao defender a vítima, tornando-se, assim, um possível alvo das agressões. ${ }^{217}$

A despeito de estarem presentes em muito menor número, há os sujeitos chamados pelos estudiosos de espectadores defensivos. Trata-se, geralmente, de um estudante que tem boas relações sociais com seus pares e age para proteger a vítima e/ou impedir que as agressões se perpetuem.

Em pesquisa realizada pela Abrapia testemunhas de bullying foram perguntadas sobre o que sentiam ao presenciar as agressões. A resposta mais mencionada, com 33,4\%, é a de que sentiram pena do agredido. Em seguida, 26,5\% das testemunhas disseram sentir-se mal com as agressões, 12,4\% relataram ter medo de que o mesmo acontecesse com elas, 8,1\% disseram não ter se incomodado, 7,7\% ficaram tristes, 5,3\% fingiram não ver, $4,2 \%$ sentiram-se bem e $2,4 \%$ ficaram com pena do agressor. ${ }^{218}$

Na interpretação de Tognetta e Vinha, entretanto, o que está em jogo nesses casos “é necessariamente a ausência de um sentimento de indignação que permita a esse espectador assumir um posicionamento contrário a ações injustas”. ${ }^{219}$

217 KOEHLER, Sônia Maria Ferreira. As faces do bullying: implicações sociais e emocionais a partir das relações interpessoais no ambiente escolar. In: ALKIMIN, Maria Aparecida (Org.). Bullying: visão interdisciplinar. Campinas: Alínea, 2011. p. 33-51.

218 OBSERVATÓRIO DA INFÂNCIA. Diga não para o bullying. Disponível em: <www.observatoriodainfancia.com.br/IMG/pdf/doc-100.pdf>. Acesso em: 2 jul. 2012.

219 TOGNETTA, Luciene Reguna Paulino; VINHA, Telma Pileggi. Estamos em conflito: eu, comigo e com você! Uma reflexão sobre o bullying e suas causas afetivas. In: CUNHA, Jorge Luiz da; DANI, Lúcia Salete Celich (Orgs.). Escola, conflitos e violências. Santa Maria: UFSM, 2008. p. 215. 


\subsubsection{Consequências}

A prática de bullying pode gerar consequências a todos os atores nela envolvidos - autores, vítimas e espectadores -, colaborando ainda para a ocorrência de mudanças negativas no ambiente em que ela ocorre.

\section{É possível afirmar que o bullying}

estimula a delinquência e induz a outras formas de violência explícita, produzindo, em larga escala, cidadãos estressados, deprimidos, com baixa autoestima, capacidade de autoaceitação e resistência à frustação, reduzida capacidade de autoafirmação e de autoexpressão, além de propiciar o desenvolvimento de sintomatologias de estresse, de doenças psicossomáticas, de transtornos mentais e de psicopatias graves. Tem, como agravante também, a interferência drástica no processo de aprendizagem e de socialização, que estende suas consequências para o resto da vida podendo chegar a um desfecho trágico. ${ }^{220}$

Fato é que com o bullying produzem-se “identidades individuais e de grupo que tendem a cristalizar-se em relações e comportamentos repetitivos, nos quais ficam gravados, de forma permanente, estereótipos, funções e rótulos”. 221

Essas caracterizações podem afetar sobremaneira o comportamento posterior dos envolvidos.

Isso porque,

um sujeito não é construído apenas por suas identificações já cristalizadas, e sim pelas ações de imposição permanentes do outro com quem ocorrem induções mútuas, um sujeito múltiplo (que seria diferente

220 CALHAU, Lélio. O fenômeno bullying: breves considerações criminológicas sobre sua possível relação com algumas práticas da delinquência juvenil. Revista MPMG Jurídico, Minas Gerais, v. 2, n. 7, p. 5353, out.-dez. 2006.

221 COSTANTINI, Alessandro. Bullying: como combatê-lo? Tradução de Eugênio Vinci de Moraes. São Paulo: Itália Nova, 2004. p. 74. 
com cada outro diferente) que participaria de alianças inconscientes, de pactos de negação. ${ }^{222}$

Logo, “as relações desestruturadas por meio de condutas abusivas e intimidatórias incidem na formação dos valores e do caráter, o que refletirá na vida do indivíduo, no campo pessoal, profissional, familiar e social”. ${ }^{223}$

A opinião dos colegas sobre o sujeito colabora na formação de sua identidade, seja positiva ou negativamente. Assim, “o grupo dos coetâneos exerce uma ligação excepcionalmente intensa, porque o adolescente retira e deriva seu status a partir de sua ligação ao grupo". 224

Desse modo, os agressores, os agredidos e os meros espectadores saem modificados dessa relação.

O bullying manifesta uma exigência de uniformização e exclusão, fruto do narcisismo individual, a qual está presente também no Estado moderno, em seu intento de dominação e controle da população. ${ }^{225}$

É preciso, pois, estar atento a essa tendência uniformizadora do grupo que expulsa o diferente, mas também aos reflexos da exclusão gerada na vítima, grande prejudicada pelo bullying.

O longo sofrimento provocado pelas agressões sistemáticas pode afetar a saúde física e mental dos seus alvos, causando-lhes problemas como anorexia, bulimia, depressão, ansiedade, estresse, dores de cabeça e estômago e até mesmo, em situações extremas, levando o sujeito ao suicídio.

222 BIGLIANI, Carlos Guillermo; MOGUILLANSKY, Rodolfo; SLUZKI, Carlos E. Humilhação e vergonha: um diálogo entre enfoques sistêmicos e psicanalíticos. Tradução de Sandra M. Dolinsky e Marta D. Claudino. São Paulo: Zagodoni, 2011. p. 24.

223 FANTE, Cleo; PEDRA, José Augusto. Bullying escolar: perguntas e respostas. Porto Alegre: Artmed, 2008. p. 37.

224 KLOSINSKI, Gunther. Adolescência hoje: situações, conflitos e desafios. Tradução de Carlos Almeida Pereira. Petrópolis: Vozes, 2006. p. 83.

225 BIGLIANI, Carlos Guillermo; MOGUILLANSKY, Rodolfo; SLUZKI, Carlos E. Humilhação e vergonha: um diálogo entre enfoques sistêmicos e psicanalíticos. Tradução de Sandra M. Dolinsky e Marta D. Claudino. São Paulo: Zagodoni, 2011. 
No ambiente escolar, pode trazer ao seu alvo dificuldade de concentração e de aprendizagem, afetar a capacidade de socialização com os colegas e motivar a evasão escolar.

Para Moguillasky,

a vergonha e a humilhação são emoções humanas que desempenham um papel central, tanto nas relações que um sujeito tem consigo mesmo, como nas que tem com os outros. Estas intervêm no ajuste que cada um possui com sua autoestima e com os valores que pensamos ter na comunidade humana que integramos e com a qual interagimos. ${ }^{226}$

Assim, a

vítima de seus iguais, tende a inculpar-se e a desvalorizar sua autoimagem, para fazer frente ao trato vexatório e à descriminação que sofre. A perda da autoestima, o sentimento de insegurança, a personalidade humilhada tudo isso leva o adolescente a associar-se em grupos de proteção, que compensarão o assédio escolar com uma reação muitas vezes violenta. ${ }^{227}$

Nesse sentido, pesquisa realizada pelo National Threat Assessment Center do Serviço Secreto norte-americano concluiu que dois terços dos autores de 37 tiroteios ocorridos em escolas sentiam-se vítimas de perseguição, ameaças, ataque e bullying, sendo este grave e protraído por um longo período de tempo. ${ }^{228}$

Para Bigliani, o fato de um sujeito ser vítima de várias humilhações sem enfrentá-las pode estruturá-lo no ressentimento, fazendo com que ele se organize no papel de vítima privilegiada ou de vingador. Assim, defende que as experiências sistemáticas de humilhação podem facilitar a transformação de um jovem em alguém capaz de perpetrar

226 BIGLIANI, Carlos Guillermo; MOGUILLANSKY, Rodolfo; SLUZKI, Carlos E. Humilhação e vergonha: um diálogo entre enfoques sistêmicos e psicanalíticos. Tradução de Sandra M. Dolinsky e Marta D. Claudino. São Paulo: Zagodoni, 2011. p. 138.

227 SHECAIRA, Sérgio Salomão. Sistema de garantias e o direito penal juvenil. São Paulo: Revista dos Tribunais, 2008. p. 121-122.

228 MIDDELTON-MOZ, Jane; ZAWADSKI, Mary Lee. Bullying: estratégias de sobrevivência para adultos e crianças. Tradução de Roberto Cataldo Costa. Porto Alegre: Artmed, 2007. 
crimes coletivos na escola, tal qual a humilhação sistemática de um povo é capaz de produzir homens bomba. ${ }^{229}$

Alguns eventos trágicos ocorridos em escolas são tidos como consequências do bullying sofrido pelos autores dos massacres.

No ano de 1999 em Littleton, Colorado, os estudantes Erick Harris, de 18 anos, e Dylan Klebold, de 17 anos, entraram armados na Columbine High School e mataram doze estudantes e um professor antes de cometerem suicídio.

Nos computadores dos garotos, entre tantos outros diálogos, o FBI coletou a seguinte frase: "Gostamos de ser diferentes e vamos matar tudo e todos que tiram sarro de nós. Estragamos e estragaremos tudo o que nos desagrada”. 230

Em 2007, o sul-coreano Seung-Hui Cho, de 23 anos, em Blacksburg, Virginia, ao abrir fogo contra alunos e funcionários da Virginia Polytechnic University, matou 32 pessoas e suicidou-se na sequência.

Seung-Hui Cho era alvo de bullying por ser de descendência sul-coreana e sofria de depressão profunda.

No Brasil, na cidade de Taiúva, no ano de 2003, o jovem Edimar Aparecido Freitas, de 18 anos, entrou armado em sua antiga escola, atirou em nove pessoas, entre alunos e funcionários de estabelecimento, e depois se matou.

Sabe-se que Edimar era estigmatizado na escola por estar acima do peso.

Em 2011, no bairro de Realengo, no Rio de Janeiro, ocorreu o maior massacre em uma escola do Brasil. Com cerca de sessenta disparos, Wellington Menezes de

229 BIGLIANI, Carlos Guillermo; MOGUILLANSKY, Rodolfo; SLUZKI, Carlos E. Humilhação e vergonha: um diálogo entre enfoques sistêmicos e psicanalíticos. Tradução de Sandra M. Dolinsky e Marta D. Claudino. São Paulo: Zagodoni, 2011.

230 TOGNOLLI, Cláudio Júlio. Nazismo redivivo: a imprensa também matou em Taiúva. Disponível em: <www.observatoriodaimprensa.com.br/artigos/jd120220031.htm>. Acesso em: 4 jul. 2012. 
Oliveira, de 23 anos, matou doze alunos e feriu outros doze de sua antiga escola, tendo cometido suicídio em seguida.

Wellington era muito calado e não tinha amigos no colégio. Por andar mancando de uma perna recebeu dos colegas os apelidos de "suingue” e de "Sherman”, este, personagem do filme adolescente American Pie. Já no trabalho, por não dar atenção às garotas, era chamado de “o virgem”.

A despeito dos acontecimentos mencionados, os casos de ações violentas são bastante raros dentro do universo das vítimas de bullying. A grande maioria das vítimas não faz mais do que sonhar com uma vingança. ${ }^{231}$ Ademais, o que se verificou na maioria dos casos, como os ocorridos na Columbine High School e na Virginia Polytechnic University, é que os jovens recorreram à violência apenas após a inação da direção das escolas. $^{232}$

Além de graves, as consequências do bullying podem ainda perdurar por um longo tempo, mesmo depois de cessadas as agressões.

É certo, então, que “o sofrimento mental provocado pela exclusão social causada pelo bullying físico ou psicológico é suficiente para destruir a autoconfiança de qualquer adulto - quanto mais uma criança - em que poderá ter efeitos para a vida toda”. 233

Olweus constatou que, ao atingirem os 23 anos, muitos estudantes que haviam sido vítimas das sistemáticas agressões passaram a estabelecer relações sociais normalmente, não demonstrando ansiedade, inibição, introversão ou estresse, o que leva a crer serem muitos desses sentimentos diretamente ligados à situação da agressão. Entretanto, em dois aspectos eles se diferenciavam dos sujeitos que não haviam sido

231 COLLINS, Randall. Violence: a micro-sociological theory. Nova Jérsei: Princeton, 2008. p. 173.

232 SHARIFF, Shaheen. Ciberbullying: questões e soluções para a escola, a sala de aula e a família. Tradução de Joice Elias Costa. Porto Alegre: Artmed, 2011.

233 Idem, ibidem, p. 53. 
submetidos à citada violência: eles eram mais propensos a ter depressão e baixa autoestima. $^{234}$

Também vão nesse sentido as conclusões de Smith e Sharp, que defendem haver evidências consideráveis de que vítimas de bullying correm o risco de se tornarem infelizes e com baixa autoestima, mesmo após findadas as agressões. ${ }^{235}$

No que se refere ao agressor, tem-se que a falta de consideração com o outro, bem como a supervalorização da violência como forma de resolução de conflitos são características que podem passar a acompanhá-lo por toda sua vida.

A obtenção de vantagens à custa da subjugação do outro, alcançada por meio da violência empregada, pode fazê-lo crer ser esse um método adequado e eficaz para atingir seus objetivos. Os autores de bullying, então, aprendem - erroneamente - que podem conseguir o que querem mediante o abuso do seu poder sobre outras pessoas.

Em decorrência disso, verifica-se maior probabilidade dos agressores em se envolver em atos antissociais. Olweus constatou em suas pesquisas que aproximadamente $60 \%$ dos praticantes de bullying, entre a 6. ${ }^{\text {a }}$ e 9. ${ }^{a}$ séries, apresentaram ao menos uma condenação criminal ao completarem 24 anos e em torno de 35 a $40 \%$ dos pesquisados tinham um total de três ou mais condenações. ${ }^{236}$

As testemunhas, por envolverem-se menos na dinâmica das agressões são as menos afetadas pelo fenômeno, mas também não passam ilesas por ele.

De imediato, mudam seu comportamento na escola. Podem ficar inibidas em sala de aula, evitando, assim, fazer perguntas, bem como incomodadas com as agressões e amedrontadas diante da possibilidade de serem as próximas vítimas.

234 OLWEUS, Dan. Bullying at school. Oxford; Cambridge: Blackwell, 1993.

235 SMITH, Peter K.; SHARP, Sônia. The problem of school bullying. In: SMITH, Peter K.; SHARP, Sônia (Ed.). School bullying: insights and perspectives. Londes; Nova Iorque: Routkedge, 1994. p. 1-19.

236 OLWEUS, Dan. Bullying at school: long-term outcomes for the victims an effective school-based intervention program. In: HUESMANN, L. Rowel (Ed.). Aggressive behavior: current perspectives. Nova Iorque: Plenum, 1994. 
Desse modo, pode-se dizer que

os sentimentos de ansiedade, insegurança e temor também permeiam as testemunhas, fazendo com que o ambiente escolar seja repleto de desconfiança, podendo influenciar suas relações sociais futuras, tornandoos adultos desconfiados e temerosos em suas relações, devido à projeção desta desconfiança. ${ }^{237}$

Podem também, a longo prazo, desenvolver insensibilidade diante do sofrimento alheio e tornarem-se adultos individualistas e egocêntricos.

\subsubsection{A diferença que desencadeia o bullying escolar}

Conforme se demonstrou neste Capítulo, em análise realizada acerca das vítimas dessa violência, verificou-se que a percepção e a consequente não aceitação da diferença do outro são suficientes para engendrar o problema.

Nesse diapasão, assevera Costa que quando “o agressor identifica no outro qualquer tipo de diferença ou vulnerabilidade é naquele ponto que o bully vai exercer seu poder de domínio". 238

Tal percepção foi apontada em praticamente todas as pesquisas realizadas sobre o tema sem, no entanto, que se aprofundasse na compreensão da motivação dessa intolerância.

É esse, portanto, o desafio do presente excerto.

Para se atingir esse desiderato, mister fazer uma digressão sobre a aceitação da diferença nas sociedades, para que, assim, seja possível compreendê-la no âmbito escolar.

237 GUARESCHI, Pedrinho A. et al. Bullying: mais sério do que se imagina. 2. ed. Porto Alegre: EDIPUCRS, 2008. p. 67.

238 COSTA, Yvete Flávio da. Bullying - prática diabólica - direito e educação. Revista de Estudos Jurídicos UNESP, Franca, v. 15, n. 21, p. 359-378, jan.-jun. 2011. p. 362. 
Durkheim, ao analisar a evolução dos grupos sociais, identificou a existência de sociedades primitivas e contemporâneas, atribuindo a cada qual delas formas de organização diversas.

Para o autor, a maior característica das sociedades primitivas era a igualdade, uma vez que a unicidade da organização social produzia também indivíduos bastante semelhantes. Tem-se aqui que todos compartilhavam dos mesmos valores e viviam de modos semelhantes. A solidariedade, dita mecânica, é que dava o caráter de coletividade a esses indivíduos.

Já as sociedades contemporâneas ${ }^{239}$ têm por característica a diferenciação, decorrente, precipuamente, da divisão do trabalho, originada devido à especialidade das atividades realizadas. Para Durkheim, a solidariedade orgânica é que dava o caráter de grupo a esses indivíduos, sendo ela baseada na diversidade de funções exercidas por cada um e na dependência gerada a partir daí. ${ }^{240}$

Note-se, então, que as organizações sociais se modificaram em direção não à homogeneização dos indivíduos, mas à sua desigualdade, pluralidade e diversidade devidas à complexidade das relações permitidas a partir das sociedades pós-industriais.

Fato é que a heterogeneidade dos povos faz parte da própria evolução da organização social, permitindo que novas formas de vida e interação sejam pensadas e construídas.

Entretanto, a despeito de essa dessemelhança entre os indivíduos ser inerente ao enredamento das sociedades modernas, viu-se que houve ao longo da história, e ainda há, certa dificuldade em lidar com ela.

Na cronologia recente, grande exemplo disso foi o Holocausto, em que os alemães, descendentes de arianos, decidiram eliminar, entre outras categorias sociais, os

239 Importante asseverar que Durkheim viveu na França no fim do século XIX e início do século XX, sendo que a sociedade contemporânea, para ele, é a que se instituiu nesse período.

240 DURKHEIM, Émile. La división del trabajo social. Tradução de Carlos G. Posada. Madrid: Daniel Jorro, 1928. 
judeus, povo que consideravam inferior, e esse evento provocou o maior massacre organizado contra um grupo social, contabilizando cerca de seis milhões de mortes.

Ao analisar os extermínios de judeus ocorridos nos campos de concentração, Christie identifica três possíveis interpretações para esse fato. Relata que, em primeiro lugar, surgiu uma corrente que defendia que o massacre foi produto das mentes anormais de seus idealizadores. Depois, ventilou-se que os envolvidos nas mortes não eram pessoas anormais, mas ao contrário, indivíduos perfeitamente normais incluídos em sistemas sociais desviantes. Finalmente, uma terceira perspectiva, exposta por Bauman, é interpretada por Christie nos seguintes termos: “O extermínio não é mais visto como uma exceção, mas como uma extensão lógica de nosso principal tipo de organização social. Nesta perspectiva, o Holocausto se torna um resultado natural de nosso tipo de sociedade, não uma exceção”. ${ }^{241}$

Assim, amparando as ideias de Bauman, Christie assevera que o extermínio não é a exteriorização de pessoas más, seres incomuns, e sim produto de uma sociedade industrializada, de seus modelos organizacionais e de pensamento. ${ }^{242}$

Trata-se da consequência de as sociedades modernas ${ }^{243}$ não aceitarem a diversidade humana, mesmo sendo ela cada vez mais evidente.

Nesse sentido assevera Gauer que tal violência representa uma compulsão pela busca da igualdade, da homogeneização das pessoas, a despeito de a

241 CHRISTIE, Nils. A indústria do controle do crime: a caminho dos GULAGs em estilo ocidental. Tradução de Luis Leiria. Rio de Janeiro: Forense, 1998. p. 172.

242 Idem, ibidem. Para Christie, o sistema carcerário norte-americano avança na mesma direção do Holocausto. Nesse sentido assevera o autor que "o pior pesadelo nunca irá se materializar. As populações perigosas nunca serão exterminadas, exceto os que forem executados em função da pena capital. Mas há grandes riscos de que os que forem identificados como sendo a essência da população perigosa sejam confinados, armazenados, depositados e forçados a viver seus anos mais ativos como consumidores do controle. Isso pode ser feito democraticamente e sob o estrito controle das instituições legais”. Cf. CHRISTIE, Nils. A indústria do controle do crime: a caminho dos GULAGs em estilo ocidental. Tradução de Luis Leiria. Rio de Janeiro: Forense, 1998. p. 186.

243 A modernidade é o período histórico iniciado em meados do século XV quando da criação dos Estados soberanos. 
diferenciação entre os indivíduos ser compatível com a evolução das formas de organização social. ${ }^{244}$

Contudo, a substituição dos governos totalitários por modelos mais democráticos de organização não foi suficiente para mudar esse panorama. Por incorporarem o povo ao poder, as democracias são consideradas, idealmente, um marco institucional não violento, uma evolução em busca da harmonização social.

Não obstante, juntamente com a implementação do processo democrático, o que se assistiu foi a um aumento das manifestações de violência.

Para Karstedt, o citado incremento deriva, precipuamente, do aumento da violência interpessoal no transcurso da evolução democrática, nos países da Europa Oriental, América Latina e África, bem como das manifestações de violência étnica. ${ }^{245}$

Fato é que, as sociedades ocidentais pós-industriais são marcadas por um grande paradoxo,

por um lado, ajudam a consolidar princípios e valores universais conquistados a duras penas pela modernidade e por ela consagrados, sobretudo através da Declaração universal dos direitos do homem. Valores como liberdade, justiça, pluralidade, tolerância, autonomia e dignidade, entre outros, se apresentam como o signo de toda e qualquer orientação moral universalista, materializados, inclusive, através do direito e da política mediante a figura do estado de direito republicano. Por outro lado, tais sociedades convivem com uma mentalidade relativista e com fenômenos como o encolhimento da moral à esfera privada, o individualismo hedonista, narcisista e consumista, bem como a anomia que permeia alguns de seus contextos. ${ }^{246}$

244 GAUER, Ruth Maria Chittó. História de violência e desagregação: a igualdade imprime a desigualdade. In: WUNDERLICH, Alexandre (Coord.). Política criminal contemporânea: criminologia, direito penal e direito processual penal. Porto Alegre: Livraria do Advogado, 2008. p. 19-31.

245 KARSTEDT, Susanne. Democracia, valores e violencia: paradojas, tensiones y ventajas comparativas de la inclusión liberal. In: SERRANO MAÍLLO, Alfonso; GUZMÁN DÁLBORA, José Luis (Eds.). Procesos de infracción de normas y de reacción de normas: dos tradiciones criminológicas. Madrid: Dykinson, 2008. p. 277-312.

246 CENCI, Angelo Vitório. Subjetividade, individualismo e formação moral no contexto de sociedades complexas e moralistas. In: TREVISAN, Amarildo Luiz; TOMAZETTI, Elisete Medianeira; ROSSATTO, Noeli Dutra (Orgs.). Diferença, cultura e educação. Porto Alegre: Sulina, 2010. p. 67. 
Nas últimas décadas, a sociedade tem testemunhado, mais uma vez, profundas transformações sociais, econômicas e políticas, em direção à pós-modernidade, que contribuem sobremaneira para a mudança das relações sociais, bem como das relações jurídicas que aí se estabelecem.

Fato é que há resistência de alguns autores em reconhecer que existe um momento na história da organização social que suplanta a modernidade.

Não obstante essa discussão, independentemente do nome elegido para referenciá-las, as sociedades atuais são plurais. Nelas, os valores não são os mesmos para todos, foram relativizados, sendo eles, pois, muito mais fluidos, o que faz com que Bauman denomine esse período histórico-social modernidade líquida e não pósmodernidade. $^{247}$

Suas principais características são a ocorrência de grandes transformações em todas as dimensões da vida das pessoas, o aparecimento contínuo de novas tecnologias, a massificação do acesso às mídias, o surgimento e diversificação dos códigos morais; as mudanças nas relações de trabalho, a crescente juridicização da vida e dos conflitos sociais, a exacerbação do individualismo, o incremento do consumo, o enfraquecimento do papel da autoridade, bem como a massificação e mercantilização do ensino. ${ }^{248}$

Destaque-se, nesse contexto de significativas mudanças, a que se refere à transformação nas relações entre as pessoas.

Em primeiro lugar, as conexões entre os indivíduos difundiram-se, precipuamente em decorrência da modernização e da expansão dos meios de comunicação

\footnotetext{
247 BAUMAN, Zygmunt. O mal-estar da pós-modernidade. Tradução de Mauro Gama e Cláudia Martinelli Gama. Rio de Janeiro: Jorge Zahar, 1998.

248 CENCI, Angelo Vitório. Subjetividade, individualismo e formação moral no contexto de sociedades complexas e moralistas. In: TREVISAN, Amarildo Luiz; TOMAZETTI, Elisete Medianeira; ROSSATTO, Noeli Dutra (Orgs.). Diferença, cultura e educação. Porto Alegre: Sulina, 2010. p. 67-79. Para Christie, apesar da diversidade das pessoas vivemos uma época monoinstitucional. Vivemos sob o imperialismo institucional, decorrente da instituição da produção, do comércio, dinheiro e consumo. Outrora, as sociedades caracterizavam-se por um pluralismo institucional. Por mais que houvesse uma prevalência da religião, outras instituições também tinham seu espaço. Cf. CHRISTIE, Nils. A indústria do controle do crime: a caminho dos GULAGs em estilo ocidental. Tradução de Luis Leiria. Rio de Janeiro: Forense, 1998.
} 
virtuais. Ademais, em consequência, foram grandemente potencializadas as possibilidades de graves colidências e conflitos sociais entre as pessoas - que agora livremente expõem suas crenças e sua multiculturalidade -, podendo eles atingir enormes proporções. Mais relações, mais gente, mais conflitos.

Acrescente-se ainda o fato de a preservação da individualidade ter atingido importância fundamental nas sociedades pós-modernas, diante do crescente temor suplantado pelo aumento dos riscos sociais.

Fato é que as pessoas não se importam mais com os outros. A tendência é de que nos cerquemos cada vez mais de pessoas que mal conhecemos ou que a qualquer hora partirão, buscando novos rumos para sua existência. ${ }^{249}$

Assim, hodiernamente, vive-se diante do problema fundamental de como harmonizar pacificamente a diversidade humana.

Sendo assim, nos locais onde o convívio de pessoas é forçado, tal qual na escola, essas colidências são levadas ao extremo. Nesse contexto, a assunção de uma atitude individualista acirra as dificuldades na busca da harmonia entre os estudantes. A percepção da diferença, portanto, como limitadora da interação social, torna-se fundamental.

Conforme assevera Gauer, a questão da diferença, e consequentemente da igualdade entre os indivíduos que conformam a coletividade, é a grande problemática das sociedades atuais, sendo ela central no debate sobre a violência contemporânea. ${ }^{250}$

É a percepção e o esforço na mantença dessa diferença que têm orientado manifestações de violência contra o outro, em diversos espectros da vida coletiva, até mesmo na escola.

249 CHRISTIE, Nils. A indústria do controle do crime: a caminho dos GULAGs em estilo ocidental. Tradução de Luis Leiria. Rio de Janeiro: Forense, 1998.

250 GAUER, Ruth Maria Chittó. História de violência e desagregação: a igualdade imprime a desigualdade. In: WUNDERLICH, Alexandre (Coord.). política criminal contemporânea: criminologia, direito penal e direito processual penal. Porto Alegre: Livraria do Advogado, 2008. p. 19-31. 
Historicamente, podem-se identificar duas facetas na afirmação da diferença.

Certos grupos sociais subjulgados esforçam-se para exaltar suas características distintivas, na tentativa de unir e preservar o agrupamento.

Assim,

uma prática que se tem desenvolvido ao longo da história e principalmente neste século é a de corajosamente transformar em qualidades as identidades constituídas como dominadas e inferiores. $\mathrm{O}$ dominado, em vez de apagar as diferenças para se tornar igual ao dominador, acentua exatamente as diferenças que o dominador havia construído. O famoso slogan "Black is beautiful" é inaugural e paradigmático nesse sentido. ${ }^{251}$

Nesse mister é importante a referência à ideia de igualdade que, hodiernamente, coaduna-se perfeitamente com a noção de diferença, uma vez que, conforme já se mencionou, é inerente à evolução das sociedades a distinção dos sujeitos que a compõem.

Em sua origem, a igualdade surge como o direito de todos serem considerados da mesma forma diante da lei. Trata-se da defesa de uma igualdade formal entre os indivíduos, do pressuposto de que, apesar das disparidades entre as raças, gênero e classe social, todos merecem ser tratados da mesma maneira, com a mesma dignidade.

Depois, com a aparição dos movimentos pelo reconhecimento dos direitos dos negros e das mulheres, precipuamente, surge a necessidade de compreendê-la em um sentido substancial, como reconhecimento e respeito à diferença. ${ }^{252}$

251 PINTO, Celi Regina Jardim. Para além da tolerância. In: BIASOLI-ALVES, Zélia Maria Mendes; FISCHMANN, Roseli (Orgs.). Crianças e adolescentes: construindo uma cultura da tolerância. São Paulo: Edusp, 2001. p. 55.

252 O movimento pelo reconhecimento dos direitos civis dos negros foi encabeçado por Martin Luther King, impulsionado pela recusa por parte de uma negra chamada Rosa Parks a ceder seu assento no ônibus a um homem branco. O movimento feminista contemporâneo também ganhou força nesse período, no fim da década de 1960, com a luta das mulheres pelo reconhecimento de sua igualdade em relação aos homens e, consequentemente, pelo fim do seu estigma de inferioridade. Cf. ARAUJO, Fernanda Carolina de. A teoria criminológica do labelling approach e as medidas socioeducativas. 
Percebe-se, então, que

a igualdade exige uma relação entre entes distintos, o que marca a passagem do sustentáculo primaz da igualdade para a heterogeneidade, a diferença entre as pessoas, cuja função pragmática é permitir a vida pacífica entre os diferentes grupos presentes na sociedade. Logo, a igualdade substancial passa a se configurar, também, como direito à diferença. ${ }^{253}$

\section{Ainda para Costa,}

o abandono do entendimento da igualdade como direito de ser igual, para a sua compreensão como diferença, tem o condão de impedir que políticas de homogeneização e de recusa dessas diferenças em nome da universalidade da lei sejam implementadas. Essa transição demonstra que a inspiração das ações estatais é, pois, a internalização da heterogeneidade da própria sociedade, somente possível pela tolerância. ${ }^{254}$

Outros grupos sociais, porém, optam por uma segunda forma de se relacionarem com o outro. Eles insistem na marcação de suas diferenças, não positivamente, mas como estratégia de um projeto de dominação e evidenciação de seu preconceito.

Conforme analisa Peralva,

a noção de igualdade tem significados múltiplos e inesgotáveis, fato que Tocqueville já reconhecia em A democracia na América. È assunto sempre controvertido e contém sempre uma parte de ficção. A desigualdade é sempre mais ou menos irredutível. Mas o que fundamentalmente caracteriza a experiência democrática é a capacidade dos indivíduos de se considerarem uns aos outros iguais - a disposição para acreditarem que de fato são iguais. Sejam quais forem os limites desse tipo de crença, seja qual for também o tipo de resposta adotado para resolver a questão da desigualdade social, a experiência democrática

2010. 251f. Dissertação (Mestrado em Criminologia) - Faculdade de Direito, Universidade de São Paulo, [2010].

253 COSTA, Igor Sporch da. Igualdade na diferença e tolerância. Viçosa: UFV, 2007. p. 59-60.

254 Idem, ibidem, p. 64. 
sempre esteve ao mesmo tempo associada a uma ideia de uma lei comum, à qual todos deveriam intempestivamente referir-se. ${ }^{255}$

O grande problema não é identificar diferenças entre os indivíduos, notar o que os distingue, e sim hierarquizar essas dessemelhanças, subjugando, em consequência, um grupo social ao outro.

Nesse diapasão, assevera Silva que

há muito tempo o ser humano vê o seu semelhante como algo estranho. Essa estranheza acontece pelo fato de se fazer uma análise comparativa entre as diversas culturas ou formas de ser. A análise comparativa não seria problema se as culturas não fossem colocadas de maneira hierárquica numa escala de valor. Ou seja, ao entrar em contato com outra expressão cultural, o ser humano procurou estabelecer a superioridade de uma sobre a outra ou classificar uma cultura como sendo melhor do que a outra. ${ }^{256}$

A conceituação do diferente é, pois, sempre comparativa. Elege-se uma realidade social como a melhor, opondo-se a ela tudo o que dela diverge. Assim, “o ato de afirmar a identidade e a unidade cultural de um grupo humano implica, muitas vezes, a rejeição de culturas diferentes que potencialmente possam ameaçá-la”. 257

Assim,

linhas que quase sempre falam de inferioridade e superioridade, de inclusão e exclusão, algumas muito fortes, sublinhadas, outras mais tênues, atributos que quase sempre se acham fora do controle dos próprios indivíduos por eles identificados, mais ainda, cujo significado positivo ou negativo também escapa do controle individual apesar do eventual empenho em afastar a valoração negativa aderida ao traço coletivamente compartilhado. Marca sensível, o mais das vezes visível,

255 PERALVA, Angelina. Violência e democracia: o paradoxo brasileiro. São Paulo: Paz e Terra, 2000. p. 19.

256 SILVA, Clemildo Anacleto da. Educação, tolerância e direitos humanos: a importância do ensino de valores na escola. Porto Alegre: Sulina; Universitária Metodista, 2009. p. 49.

257 CARDOSO, Clodoaldo Meneguello. Fundamentos filosóficos da intolerância. In: CARDOSO, Clodoaldo Meneguello (Org.). Convivência na diversidade: cultura, educação e mídia. Bauru: Unesp; FAAC, 2008. p.16. 
de uma diferença significativa, esses traços adquirem tais significados a partir de práticas sociais. ${ }^{258}$

Em outros termos, para Pinto, “o reconhecimento de que estamos frente a dois grupos distintos é o reconhecimento de que um é o grupo dos diferentes, o outro é o grupo dos normais. O primeiro se define em relação ao segundo, este se autoconstitui”. 259

Dessa forma, destaca-se a anormalidade do outro para evidenciar-se a normalidade de um.

Bauman, em sua obra $O$ mal-estar da pós-modernidade, analisa essa problemática. Para ele, em todas as sociedades sempre se identificou a presença dos estranhos. Ou melhor, as organizações sociais sempre produziram seus próprios estranhos, razão pela qual o que se considera diferente, o que incomoda, não é sempre a mesma categoria de pessoas: cada tempo e cada lugar criam seus próprios demônios, os grupos que deverão ser perseguidos ou rejeitados.

Entretanto, curiosamente, "quando se fala de diferença, está-se falando de mulheres, negros, índios, velhos, crianças, homossexuais, deficientes físicos e mentais. A lista poderia estender-se, mas certamente dela nunca constariam homens brancos adultos de classe média ou da burguesia”. 260

De todo modo, quem quer que sejam, eles sempre incomodam por ameaçarem a segurança e a certeza que se busca na vida cotidiana. Exatamente pelo incômodo que produzem é que se tem procurado um espaço para que esse indesejável possa ser marcado e corrigido “até porque, na ordem harmoniosa e relacional, não há

258 PIERUCCI, Antônio Flávio. Problemas com a igualdade (ou: ciladas da diferença). Cadernos de Sociologia, Porto Alegre, n. especial, p. 149-158, 1995. p. 149.

259 PINTO, Celi Regina Jardim. Para além da tolerância. In: BIASOLI-ALVES, Zélia Maria Mendes; FISCHMANN, Roseli (Orgs.). Crianças e adolescentes: construindo uma cultura da tolerância. São Paulo: Edusp, 2001. p. 52.

260 Idem, ibidem, p. 52. 
espaço para aqueles que constrangem e alteram a serenidade e a tranquilidade dos demais”. 261

Nas palavras de Bauman, “o estranho despedaça a rocha sobre a qual repousa a segurança da vida diária”, 262

Assim, assevera o autor que

todas as sociedades produzem estranhos. Mas cada espécie de sociedade produz sua própria espécie de estranhos e os produz de sua própria maneira, inimitável. Se os estranhos são as pessoas que não se encaixam no mapa cognitivo, moral ou estético do mundo - num desses mapas, em dois ou em todos três; se eles, portanto, por sua simples presença, deixam turvo o que deve ser transparente, confuso o que deve ser uma coerente receita para a ação, e impedem a satisfação de ser totalmente satisfatória; se eles poluem a alegria com a angústia, ao mesmo tempo que fazem atraente o fruto proibido; se, em outras palavras, eles obscurecem e tornam tênues as linhas de fronteira que devem ser claramente vistas; se, tendo feito tudo isso, geram a incerteza, que por sua vez dá origem ao mal-estar de se sentir perdido - então cada sociedade produz esses estranhos. Ao mesmo tempo que traça suas fronteiras e desenha seus mapas cognitivos, estéticos e morais, ela não pode senão gerar pessoas que encobrem limites julgados fundamentais para a sua vida ordeira e significativa, sendo assim acusadas de causar a experiência do mal-estar como a mais dolorosa e menos tolerável. ${ }^{263}$

A pós-modernidade caracteriza-se pela permanente incerteza. ${ }^{264}$ Nesse diapasão, seu trabalho na produção dos estranhos também é precário. Já não existe a

261 LUNARDI-LAZZARIN, Márcia Lise. Os disursos da diferença no contexto das políticas de inclusão: a anormalidade no detalhe. In: TREVISAN, Amarildo Luiz; TOMAZETTI, Elisete Medianeira; ROSSATTO, Noeli Dutra (Orgs.). Diferença, cultura e educação. Porto Alegre: Sulina, 2010. p. 149.

262 BAUMAN, Zygmunt. O mal-estar da pós-modernidade. Tradução de Mauro Gama e Cláudia Martinelli Gama. Rio de Janeiro: Jorge Zahar, 1998. p. 19.

263 Idem, ibidem, p. 27.

264 Para Bauman a marca da modernidade era a certeza, a certeza de que se caminhava em direção ao moderno, ao atualizado, razão pela qual era evidente a segurança que se oferecia aos indivíduos. Já hoje, é elementar à pós-modernidade a liberdade individual: os valores são mutáveis, é a época de movimento, o mundo é polifônico. Alcança a maior posição social quem tem mais liberdade. Cf. BAUMAN, Zygmunt. O mal-estar da pós-modernidade. Tradução de Mauro Gama e Cláudia Martinelli Gama. Rio de Janeiro: Jorge Zahar, 1998. 
clareza e a definitividade sobre quem são os perigosos, quem são os sujeitos que devem ser combatidos.

Logo, nela

os estranhos já não são autoritariamente pré-selecionados, definidos e separados, como costumavam ser nos tempos dos coerentes e duráveis programas de constituição da ordem administrados pelo estado. Agora, eles são tão instáveis e proteicos como a própria identidade de alguém, e tão pobremente baseados, tão erráticos e voláteis [...] essa diferença_[...] precisa ser construída e reconstruída, e construída uma vez mais, e de novo reconstruída, nos dois lados ao mesmo tempo, nenhum dos lados se gabando de maior durabilidade, ou exatamente da "gratuidade", do que o outro. Os estranhos de hoje são subprodutos, mas também os meios de produção no incessante, porque jamais conclusivo, processo de construção da identidade. ${ }^{265}$

Note-se, que, de acordo com esse pensamento, qualquer um, em dado momento, pode ser enquadrado na categoria de estranho e sofrer as consequências negativas desse rótulo. Os outros, portanto, continuarão existindo.

Assim, para Bauman, “a questão já não é como se livrar dos estranhos e do diferente uma vez por todas, ou declarar a diversidade humana apenas uma inconveniência momentânea, mas como viver com a alteridade, diária e permanentemente”. ${ }^{266}$

Note-se que Baumam, ao defender que cada sociedade produz seus próprios estranhos, evidencia ser essa categoria construída socialmente e não uma característica de certos tipos de pessoas. Nesse diapasão assevera Lunardi-Lazzarin que "na sociedade moderna e, então, normativa, tudo o que é extremo, tudo o que está fora do lugar incomoda, daí, a necessidade constante de estar ordenando e normalizando. No entanto,

265 BAUMAN, Zygmunt. O mal-estar da pós-modernidade. Tradução de Mauro Gama e Cláudia Martinelli Gama. Rio de Janeiro: Jorge Zahar, 1998. p. 37.

266 Idem, ibidem, p. 44. 
trata-se de um modelo de ordem que se desloca - portanto, que gera sempre novos alvos”. ${ }^{267}$

Fato é que "os discursos da diferença não são naturais, mas socialmente construídos num processo produzido pela linguagem, pela forma como essa privilegia ou exclui determinados significados”. ${ }^{268}$ Trata-se de uma diferença discursiva conectada com relações de poder.

Insta salientar também que a negação da diferença, o olhar negativo sobre o outro, identifica uma interface importante entre as noções de diferença e preconceito.

Se não se aceita o diferente, o próximo passo será a realização de sua exclusão, por intermédio de ações preconceituosas.

Assim,

o preconceito expressa-se em um juízo de valor que considera o outro ou um grupo como inferior a nós em algum aspecto: física, moral, social ou intelectual. $\mathrm{O}$ ato preconceituoso, portanto, sustenta-se pela crença na desigualdade natural entre os seres humanos e isso implica em considerar-se como possuidor da verdade absoluta e como padrão de comportamento de referência para todos. ${ }^{269}$

Nas palavras de Bobbio,

entende-se por "preconceito" uma opinião ou um conjunto de opiniões, às vezes até mesmo uma doutrina completa, que é acolhida acrítica e passivamente pela tradição, pelo costume ou por uma autoridade de quem aceitamos as ordens sem discussão: "acriticamente" e "passivamente”, na medida em que aceitamos sem verificá-la, por inércia, respeito ou temor,

267 LUNARDI-LAZZARIN, Márcia Lise. Os disursos da diferença no contexto das políticas de inclusão: a anormalidade no detalhe. In: TREVISAN, Amarildo Luiz; TOMAZETTI, Elisete Medianeira; ROSSATTO, Noeli Dutra (Orgs.). Diferença, cultura e educação. Porto Alegre: Sulina, 2010. p. 151.

268 LUNARDI-LAZZARIN, Márcia Lise. Os disursos da diferença no contexto das políticas de inclusão: a anormalidade no detalhe. In: TREVISAN, Amarildo Luiz; TOMAZETTI, Elisete Medianeira; ROSSATTO, Noeli Dutra (Orgs.). Diferença, cultura e educação. Porto Alegre: Sulina, 2010. p. 143.

269 CARDOSO, Clodoaldo Meneguello. Fundamentos filosóficos da intolerância. In: CARDOSO, Clodoaldo Meneguello (Org.). Convivência na diversidade: cultura, educação e mídia. Bauru: Unesp; FAAC, 2008. p. 17. 
e a aceitamos com tanta força que resiste a qualquer refutação racional, vale dizer, a qualquer refutação feita com base em argumentos racionais. Por isso se diz corretamente que o preconceito pertence à esfera do não racional, ao conjunto das crenças que não nascem do raciocínio e escapam de qualquer refutação fundada num raciocínio. ${ }^{270}$

Note-se que, para o autor, o aspecto prevalente do preconceito - fator em que reside sua maior danosidade social -, refere-se ao fato de ele ser irracional e, portanto, movido por paixões e interesses escusos de quem o pratica.

Nesse diapasão, os preconceitos coletivos são ainda mais perigosos em cotejo com os individuais, já que eles servem à justificação de todo um grupo social contra o outro, gerando incompreensão, rivalidade, desprezo ou escárnio, podendo degenerar em violência. E como principais manifestações de preconceitos coletivos Bobbio menciona os relativos às diferenças de raças, nacionalidades e classes sociais. ${ }^{271}$

Sua principal consequência é a discriminação. Assim,

“discriminação" significa qualquer coisa a mais do que diferença ou distinção, pois é sempre usada com uma conotação pejorativa. Podemos, portanto, dizer que por "discriminação" se entende uma diferenciação injusta ou ilegítima. Por que injusta ou ilegítima? Porque vai contra o princípio fundamental da justiça, segundo a qual devem ser tratados de modo igual aqueles que são iguais. Pode-se dizer que se tem uma discriminação quando aqueles que deveriam ser tratados de modo igual, com base em critérios comumente aceitos nos países civilizados, são tratados de modo desigual. ${ }^{272}$

A escola é uma instituição social. Desse modo ela reproduz, total ou parcialmente, a conjuntura social e os conflitos que lá se desenrolam, além de produzir os seus próprios.

270 BOBBIO, Norberto. Elogio da serenidade e outros escritos morais. Tradução de Marco Aurélio Nogueira. São Paulo: Unesp, 2002. p. 103.

271 Idem, ibidem.

272 Idem, p. 107. 
Nela, a diferença também é notada e rechaçada pelos estudantes e é elemento fundamental na determinação das vítimas do bullying.

O estranho é excluído, expatriado, enquanto os demais se organizam nos grupos que lhes dão prestígio social. O diferente, assim, é obrigado a isolar-se ou buscar integrar-se em um grupo em que a única afinidade entre seus membros é o fato de todos terem sido segregados.

Nesse caso, tem-se que

o grupo que nos define, nos ajuda a orientar nosso comportamento e se considera provedor de nossa liberdade pode não ser aquele que escolhemos conscientemente e, assim, talvez se torne um convidado indesejado. Quando nele ingressamos, não praticamos um ato de liberdade, mas uma manifestação de dependência. ${ }^{273}$

Ocorre que tal conjuntura torna-se aqui ainda mais relevante já que os adolescentes estão em um momento de formação de suas identidades e fazer parte do grupo social incluído torna-se ainda mais significativo, pois elemento de construção de suas personalidades.

Isso posto, tem-se que o bullying se engendra no ambiente escolar também como forma de construir e sedimentar os papéis sociais dos estudantes.

Nesse diapasão,

as manifestações de violência nas escolas não são à parte do funcionamento do estabelecimento, não são momentos isolados da aprendizagem ou das tarefas escolares. As manifestações de violência nas escolas são, por um lado, configuradas por fatores externos e internos, e por outro, elas mantêm ou tentam mudar a ordem das coisas, ou até se misturam na ordem das coisas. ${ }^{274}$

273 BAUMAN, Zygmunt; MAY, Tim. Aprendendo a pensar com a Sociologia. Tradução de Alexandre Werneck. Rio de Janeiro: Zahar, 2010. p. 38.

274 LATERMAN, Ilana. Violência e incivilidade na escola: nem vítimas, nem culpados. Florianópolis: Letras Contemporâneas, 2000. p. 31. 
Diante das agressões sofridas, então, há “aqueles que não podem jamais construir sua experiência escolar; que aderem com frequência aos julgamentos escolares que os invalidam e os conduzem a perceber, a si mesmos, como incapazes”. 275

Note-se, porém, que essa identificação do diferente parece ser ainda mais fluida nesse ambiente e, por vezes, opõe-se à diferença considerada positivamente no meio social mais amplo. Assim, o bom desempenho escolar costuma transformar os estudantes em alvos do bullying, a despeito de essa característica ser socialmente valorizada.

\section{Logo,}

os processos de entendimento do que significa ser diferente no contexto da escola, pode soar e cair naqueles trivialismos e folclorismos particulares de formas de vestir, de comer, de dançar e, por que não, de se comunicar. Nesse contexto, o que fica em exibição é sempre a contradição, a desconformidade do outro em relação ao um, ou melhor, ser diferente marca o lugar do outro e do um. Nessa mesma matriz, a diferença passa a ser representada como algo indesejável, incomum, devido ao seu tom de anormalidade, estranheza e exotismo. ${ }^{276}$

Entretanto, “o reconhecimento das diferenças exige que sejam todos os indivíduos considerados em sua humanidade, não se admitindo qualquer minoração deste status”. ${ }^{277}$

É preciso, portanto, perquirir como a noção de diferença se constrói em determinando ambiente social, como ela se aplica no caso concreto e também as consequências da adoção de condutas que têm por base a sua marcação.

275 DUBET, François. A formação dos indivíduos: a desinstitucionalização. Disponível em: <www.lcqribeiro.pro.br/wp-content/uploads/2011/03/A-forma\%C3\%A7\%C3\%A3o-dos-indiv\%C3\%A Dduos-DubetFran\%C3\%A7ois.pdf $>$. Acesso em: 10 jul. 2013. p. 4.

276 LUNARDI-LAZZARIN, Márcia Lise. Os disursos da diferença no contexto das políticas de inclusão: a anormalidade no detalhe. In: TREVISAN, Amarildo Luiz; TOMAZETTI, Elisete Medianeira; ROSSATTO, Noeli Dutra (Orgs.). Diferença, cultura e educação. Porto Alegre: Sulina, 2010. p. 148.

277 COSTA, Igor Sporch da. Igualdade na diferença e tolerância. Viçosa: UFV, 2007. p. 60. 


\section{3 papel do estigma e do rótulo social na interação entre os escolares}

A marcação da diferença relaciona-se com a atribuição de estigmas e rótulos sociais. Ou seja, ser estranho é um rótulo que adere ao sujeito e cuja força é capaz de transformar suas relações com a coletividade e a imagem que o rotulado sustenta de si próprio.

Assim, fundamental a compreensão do processo que culmina na imposição dessa etiqueta, bem como de suas consequências, visando a elucidar a trama que se estabelece entre os bullies e as vítimas do bullying, sujeitos marcados pela sua diferença.

Elias e Scotson discorrem sobre essa relação entre os incluídos e os excluídos, os diferentes e os normais, em seu livro Os estabelecidos e os outsiders: sociologia das relações de poder a partir de uma pequena comunidade. ${ }^{278}$

A obra, publicada originalmente no ano de 1965, apresenta o estudo, realizado na década de 1950, de uma pequena cidade ao sul da Inglaterra, de nome fictício Winston Parva.

O objetivo dos autores na obra é compreender, por meio do uso de fontes diversas, como estatísticas, entrevistas, documentos e etnografia, a lógica da configuração social e das relações de interdependência que se verificam na cidade. Violência, discriminação e exclusão social são características que se depreendem da análise social realizada.

A princípio, o objetivo dos autores era desvendar o porquê da significativa diferença nos índices de atos infracionais praticados em cada área da cidade. Entretanto, eles abandonaram tal tarefa ao se darem conta de que todas as características que emanavam daquela organização social decorriam de sua configuração, do modo como aquela sociedade se organizava, sendo esta a base da análise configuracional por eles proposta.

278 ELIAS, Norbert; SCOTSON, John L. Os estabelecidos e os outsiders: sociologia das relações de poder a partir de uma pequena comunidade. Tradução de Vera Ribeiro. Rio de Janeiro: Jorge Zahar, 2000. 
De qualquer modo, a situação verificada em Winston Parva é tida como paradigmática das que se manifestam em inúmeras outras cidades em processo de industrialização.

Winston Parva dividia-se em três zonas, três bairros distintos. Na zona um habitavam as pessoas mais privilegiadas economicamente, cuja ascensão social permitiu que elas se mudassem para a área de classe média da cidade, deixando, assim, a zona dois; nas zonas dois e três residiam os operários das fábricas locais.

Contudo, por detrás da aparente semelhança existente entre os residentes dessas duas últimas áreas da cidade, profundas disparidades foram verificadas entre seus grupos, uma vez que os habitantes da zona dois, território mais antigo de Winston Parva, consideravam-se superiores aos demais, pelo simples fato de habitarem o local há mais tempo.

Não existiam, pois, diferenças étnicas, nos níveis de desenvolvimento econômico ou educacional, nem mesmo de atividade profissional entre esses sujeitos, mas, mesmo assim, os habitantes da zona dois, chamada por eles próprios de “aldeia”, negavamse a manter contato com os recém-chegados da zona três, o "loteamento”, exatamente pelo fato de serem recém-chegados, de serem outsiders na terra daqueles estabelecidos. ${ }^{279}$

Note-se, portanto, que a diferença pejorativa aqui foi construída simplesmente em virtude do local e do tempo de moradia de determinada parcela da população. A maior coesão entre os membros das zonas habitacionais um e dois facultava a exclusão e estigmatização dos membros da zona três.

Nesse diapasão, os autores chamam a atenção para a diferenciação existente entre preconceito individual e a estigmatização grupal praticada em Winston Parva. Aquela tem sua raiz na personalidade dos indivíduos, enquanto esta, verificada na

279 Importante destacar que a palavra outsider é bastante significativa na tradição sociológica, tanto que ela não costuma ser traduzida para outro idioma junto com o restante da obra que a contém. Howard Becker a cunhou no citado ramo do conhecimento no ano de 1963, ao publicar o livro Outsiders: studies in the sociology of deviance, traduzido para o português como Outsiders: estudos de sociologia do desvio. A inspiração do sociólogo no uso do termo adveio da leitura da obra literária L'étranger [O estrangeiro], de Albert Camus. 
cidade pesquisada, pela qual um grupo rotula negativamente outro, tem como elemento fundamental a instabilidade do equilíbrio do poder entre agrupamentos sociais distintos.

Assim, evidencia-se que "quando as pessoas aceitam que existe um diferente, aquele que será vítima da violência do grupo (do sacrifício, da justiça), e se une em torno disso, constrói o outro e o nós, e nesse sentido, constrói o grupo, funda o grupo”. ${ }^{280}$

Ocorre que o grupo pode tanto encorajar práticas de liderança e valorização do outro quanto acoroçoar e estimular comportamentos antissociais ou de violência, que um indivíduo isolado não praticaria. ${ }^{281}$

Fato é que essa configuração social mostrará sua influência em inúmeros aspectos da vida daqueles grupos, como em sua organização familiar, índices de criminalidade, relação entre os vizinhos, entre outras, passando a ser considerada essencial na análise desenvolvida no livro.

Como "preço" pela mantença do reconhecimento desejado, os membros dos grupos superiores tornam-se reféns de seu papel, pois ficam obrigados a reafirmar - a todo o tempo - sua identificação e integração grupal, e também a preservar o valor maior do seu grupo, limitando, assim, sua esfera de liberdade nas ações pessoais.

Já em relação aos habitantes da zona três, os rótulos a eles aplicados acabam sendo incorporados à própria descrição desse grupo, materializando-se. Trata-se de uma visão negativa que provocou a condenação global do loteamento.

No que se refere aos hábitos de asseio pessoal, por exemplo, sua área de residência fica conhecida como "beco dos ratos", em virtude da rotulação daqueles sujeitos como sujos e anti-higiênicos, o que faz com que os outros creiam ser esta uma característica real dos excluídos.

280 LATERMAN, Ilana. Violência e incivilidade na escola: nem vítimas, nem culpados. Florianópolis: Letras Contemporâneas, 2000. p. 27.

281 SAITO, Marta Ignez. Violência interpessoal na adolescência. In: WESTPHAL, Márcia Faria; BYDLOWSKI, Cynthia Rachid (Eds.). Violência e juventude. São Paulo: Hucitec, 2010. 
Ainda nesse processo de inferiorização, exercem função precípua as fofocas depreciativas e a maculação da autoimagem dos outsiders. Aquelas permitem que as generalizações negativas se espalhem e sejam tomadas como verdadeiras, enquanto estas minam qualquer possibilidade de defesa e união entre os membros do grupo inferiorizado, os quais não esboçam nenhuma reação contra a qualificação negativa que lhes foi aplicada.

Vale ressaltar que os autores identificaram uma estreita relação entre a fofoca praticada e a estrutura da comunidade em que ela se realiza. A aldeia necessitava de um fluxo constante de fofocas para manter-se em funcionamento e a maior coesão social entre os membros desse grupo facilitava sua difusão. Aqui, pois, ela aparece como um mecanismo integrador e reafirmador da superioridade grupal.

No loteamento, em contrapartida, a falta de coesão e até mesmo de contato entre seus residentes, bem como a desconfiança que uns tinham em relação aos outros, em decorrência da imagem gerada pelo estigma, obstaculizavam seu exercício.

Conforme mencionado, a própria organização familiar diferia substancialmente nas zonas dois e três. Na zona dois, as famílias eram mais unidas e dependentes, sendo central nesse contexto a figura da mãe, a qual tinha a capacidade de unir vários núcleos familiares distintos (famílias ampliadas). Sendo assim, a mesma coesão identificada no seio social também se apresentava no âmbito familiar. Na zona três, entretanto, as famílias eram pequenas e viviam de forma isolada, uma vez que a conformação ao estigma aplicado fazia com que se evitasse contato com os vizinhos não confiáveis.

Tal constatação permitiu aos autores desmistificar a ideia de que a família é unidade básica e primária de qualquer sociedade, ficando evidente, em contrapartida, ser ela produto da comunidade que a abraça.

Pode-se defluir, então, do cenário traçado, que o controle social informal era bastante mais forte na aldeia. Todas as características do bairro corroboravam para que a vigilância fosse mais eficaz: a forte coesão entre os membros, o fato de eles participarem de associações comunitárias e as fofocas, utilizadas como instrumento de regulação de condutas. 
No loteamento, porém, nada disso se verificava. O estigma que carregavam fazia com que os próprios vizinhos temessem uns aos outros e a falta de agremiações na comunidade e de espaços conjuntos de lazer fazia com que o contato entre os coabitantes não se estabelecesse, impedindo a efetivação de um controle social informal.

É, pois, diante de todo esse contexto que se podem explicar as diferenças nos índices de criminalidade juvenil nas zonas de habitação dois e três.

Onde falha o controle social informal sobressai a criminalidade. ${ }^{282}$

Ademais, a autoimagem negativa desenvolvida pelos jovens da zona três em decorrência do estigma por eles suportado fazia com que muitos deles, intencionalmente, se amoldassem à representação construída e agissem buscando sua correspondência. Portanto, o delito não passava da adequação ao papel que lhes fora atribuído pela sociedade.

Apropriando-se das palavras dos escritores, pode-se dizer que "o palco dos conflitos e tensões psicológicos individuais era ligado ao dos conflitos e tensões sociais". 283

Desse modo, o que os autores constataram foi que

as tentativas de estudar os delinquentes, explicá-los e fazer previsões a seu respeito, unicamente com base em critérios individuais, através de diagnósticos psicológicos não corroborados por diagnósticos sociológicos, não costumam ser dignas de confiança. É que as condições de reprodução contínua dos grupos de jovens delinquentes encontram-se na estrutura da sociedade e particularmente na das comunidades onde moram grupos de famílias com filhos “delinquentes” e onde essas crianças crescem. ${ }^{284}$

\footnotetext{
282 A problemática acerca do controle social informal será explanada no capítulo 3.

283 ELIAS, Norbert; SCOTSON, John L. Os estabelecidos e os outsiders: sociologia das relações de poder a partir de uma pequena comunidade. Tradução de Vera Ribeiro. Rio de Janeiro: Jorge Zahar, 2000. p. 149.

284 Idem, ibidem, p. 140.
} 
Portanto, o livro consegue identificar e elucidar as relações de poder, dependência e exclusão - baseadas na identificação e hierarquização da diferença existentes em uma sociedade e suas implicações em todos os níveis de sua organização, bem como em todos os aspectos da vida dos habitantes.

Com base na obra resta evidente a importância da consideração que o grupo social faz do outro em termos de organização social e também na relação que o estigmatizado estabelece com seus pares.

Becker também estuda a questão dos rótulos sociais, partindo do pressuposto da existência de uma sociedade de conflitos e não de consensos. ${ }^{285}$

Nesse diapasão, assevera Dubet que podem ser identificadas na modernidade duas posições em relação às desigualdades entre os sujeitos, a própria conjuntura da organização social, as quais aludem, verdadeiramente, a uma das grandes tensões da modernidade.

Uma primeira pode ser representada pela expressão "trunfo obstinado da igualdade”286 e refere-se à sua consideração para além das desigualdades sociais reais.

Nesse sentido, a igualdade é considerada um princípio segundo o qual todas as pessoas são fundamentalmente iguais, tem condições de guiarem-se pelas mesmas metas e objetivos, sendo que o que as discerne, impedindo que elas sejam efetivamente iguais, são as diferenças de oportunidade e de direitos porventura existentes.

Já a segunda identifica-se com o reconhecimento da desigualdade como inerente à funcionalidade dos sistemas sociais modernos. Em outros termos, é a percepção

285 A contradição entre as sociedades de consenso e conflito será analisada mais detidamente no capítulo 3 do presente trabalho.

286 DUBET, François. As desigualdades multiplicadas. Tradução de Maria do Carmo Duffles Teixeira. Disponível em: <http://www.anped.org.br/rbe/rbedigital/rbde17/rbde17_03_francois_dubet.pdf >. Acesso em: 10 jul. 2013. p. 6. 
das sociedades como conflitivas, marcadas pela diversidade, ausência de uniformidade e de comunhão de valores. ${ }^{287}$

Para Becker, nesse modelo de sociedade, deve ser considerado um outsider o sujeito que não respeita os regramentos sociais, os quais não representam os anseios de toda a sociedade, e sim de determinada parcela da população com poder para impô-los, formal ou informalmente, e, assim, transformar aqueles que não os observam em desviantes. $^{288}$

De todo modo, há de se ressaltar que a imposição do rótulo não é homogênea. Ela depende da conduta praticada pelo indivíduo, conforme acima se mencionou, mas também da reação de intolerância dos demais que recai sobre o comportamento realizado e sobre seu autor. Na falta da reação que se erige contra o ato, não se produz o desviante.

Nesse sentido, assevera Becker que

os grupos sociais criam o desvio ao fazer as regras cuja infração constitui o desvio e aplicar ditas regras a certas pessoas em particular e qualificálas de marginais (estranhos). Desde este ponto de vista, o desvio não é uma qualidade do ato cometido pela pessoa, senão uma consequência da aplicação que os outros fazem das regras e sanções para um ofensor. O desviante é uma pessoa a que se pode aplicar com êxito dita qualificação (etiqueta); a conduta desviante é a conduta assim chamada pela gente. ${ }^{289}$

Ser marcado com esse rótulo tem importantes consequências na forma como o sujeito é encarado pelos demais, impulsionando o indivíduo para uma carreira de desvio.

Todo o processo de rotulação do outro analisado por Becker ocorre em três momentos distintos: a criação da regra, a sua aplicação no caso concreto e as consequências de ser identificado como um outsider.

287 AKERS, Ronald L. Criminological Theories: introduction and evaluation. 2. ed. Los Angeles: Roxbury, 1997.

288 Importante salientar que desviante não é apenas aquele que comete um ato classificado como crime, mas qualquer um que não observa os padrões estabelecidos por parcela da população.

289 BECKER, Howard S. Outsiders: studies in the sociology of deviance. Nova Iorque: The Free Press, 1997. p. 19. 
Na primeira perspectiva, o autor assevera que as normas, não sendo resultado de anseios compartilhados por todos os sujeitos que integram a coletividade, devem ser impostas por alguém, a quem ele denomina empresários morais. ${ }^{290}$

São eles, com a possibilidade que seu poder lhes fornece, que podem determinar quais as regras sociais a serem seguidas pelos demais.

Assim, no âmbito do controle social formal são eles os responsáveis pela elevação de uma conduta social à reprovável categoria de criminosa e, no espectro do controle social informal, pela criação dos chamados padrões sociais de comportamento.

Quanto à aplicação da regra, é o momento de identificação, em determinado ambiente social, dos desviantes, daqueles que se comportaram em dissonância com os regramentos estabelecidos por alguns, para todos. Trata-se, pois, da injunção da norma ao caso concreto, com o consequente reconhecimento daquele que a desrespeitou.

O controle social formal dispõe de aparatos, instituições encarregadas de exercer tal desiderato, como é o caso das Polícias, do Ministério Público e da Magistratura. Já no que se refere ao controle social informal, tal estrutura não existe. Assim, aqui, a fofoca, conforme asseverado por Elias e Scotson, a vizinhança, os colegas de escola, entre outros, é que se encarregam dessa identificação. ${ }^{291}$

Finalmente, a terceira perspectiva, de cunho psicológico-social, ocupa-se das consequências da imposição de um rótulo negativo ao que violou determinada norma social.

Em decorrência desse contato é que se atribui a etiqueta de desviado ao sujeito, iniciando sua estigmatização, a qual pode dar origem à desviação secundária e ao desenvolvimento de uma carreira desviante.

\footnotetext{
290 BECKER, Howard S. Outsiders: studies in the sociology of deviance. Nova Iorque: The Free Press, 1997.

291 A análise das espécies de controle social será realizada mais profundamente no capítulo 3.
} 
O fato de o sujeito passar a ser visto pelos demais membros da sociedade por um rótulo negativo é capaz de influenciar severamente a forma como ele mesmo se reconhece, bem como suas condutas futuras. Nesse sentido, a desviação secundária acaba sendo a resposta do sujeito à qualificação negativa que lhe foi imposta pela sociedade e da qual ele não conseguiu desvincular-se, terminando por incorporar o papel que lhe foi imposto pelos demais. O desviado secundário é alguém que se conforma com o retrato que a sociedade tem dele. ${ }^{292}$

Ocorre, pois, a cristalização da autoimagem de desviante em seguida à internalização das etiquetas estigmatizantes, sendo que o próximo passo é o estabelecimento da carreira desviante, a assunção de comportamentos compatíveis com o rótulo que lhe foi imposto.

Desse modo,

quando os outros decidem que determinada pessoa é non grata [...], eles tomarão contra tal pessoa atitudes normalmente desagradáveis, que não seriam adotadas com qualquer um. São atitudes a demonstrar a rejeição e a humilhação nos contatos interpessoais e que trazem a pessoa estigmatizada para um controle que restringirá sua liberdade. ${ }^{293}$

A captura do sujeito pelo sistema de controle social faz com que lhe seja atribuída uma etiqueta, um rótulo de desviado, e com que ele seja visto pela sociedade nos termos de sua nova qualificação. Em razão disso, estigmatizado é barrado da participação social, o que faz com que ele não consiga se inserir em um grupo social dito "normal”.

Evidente que todo esse processo acima mencionado alcança sua lesividade máxima quando exercido pela rede de controle social formal, já que é ela a responsável por transformar uma conduta em crime e punir os desobedientes. Porém, essa mesma caracterização do desvio ocorre nos sistemas de controle social informal, transformando o desviado em pessoa à margem da sociedade, em alguém que não é aceito pelo grupo social dominante daquele local.

292 BERGALLI, Roberto. Crítica a la Criminologia: hacia una teoría crítica del control social en América Latina. Bogotá: Temis, 1982.

293 SHECAIRA, Sérgio Salomão. Criminologia. 4. ed. São Paulo: Revista dos Tribunais, 2012. p. 251-252. 
Nesse diapasão, apesar de o comportamento desviado geralmente ser prescrito em lei, é possível que ele se refira às pessoas que adotam uma subcultura considerada bizarra para o restante do corpo social.

Ao longo de sua vida e em cada ambiente social em que se encontram, as pessoas desempenham papéis diferentes, os quais geram para elas direitos e obrigações. Isso porque a sociedade espera delas atitudes condizentes com o papel que assumiram, como se ela determinasse de antemão a forma como todos deveriam ser tratados e também seus padrões de comportamento perante os demais.

Assim, as obrigações, em realidade, são mais do que meras obrigações, são expectativas sociais que os sujeitos esperam que se cumpram por alguém que exerce aquele papel. Por vezes, essas expectativas estão tão arraigadas nos membros de dada sociedade que se tornam normas sociais, padrões de juízo da média da população.

A importância desse mecanismo é que da expectativa da audiência social é que depende a qualificação do desvio e do desviante. ${ }^{294}$ O indivíduo é tido como desviante quando o comportamento por ele realizado não corresponde ao seu papel, ou melhor, ao papel que a média da sociedade considera adequado.

Becker confirma essa ideia, evidenciando a importância do controle social informalmente efetivado, ao analisar a cultura de um grupo tido como desviante, conformado por músicos de jazz.

Mister salientar, desde já, que o autor trabalha numa perspectiva interacionista, razão pela qual a caracterização do desvio é relacional. Para os citados músicos o restante da sociedade - os não músicos - são considerados outsiders e denominados por eles square; enquanto para os demais, os músicos é que são desviantes, por viverem uma cultura diversa da que eles acreditam ser ideal.

Note-se, então, que os comportamentos considerados desviantes e os padrões daqueles que os julgam inaceitáveis são produtos exatamente do mesmo processo de

294 CASTRO, Lola Aniyar de. Criminologia da reação social. Tradução de Ester Kosovski. Rio de Janeiro: Forense, 1983. 
construção social, sendo certo que, muitas vezes, os padrões de um grupo coincidem com os desvios do outro. ${ }^{295}$

No caso acima citado, os músicos inferiorizam todos aqueles que não têm seu dom musical e consideram que a intromissão em seu trabalho é inaceitável. Por sua vez, os não músicos rechaçam a rotina, ou melhor, a falta de rotina dos músicos, bem como sua liberdade exacerbada em uma sociedade em que o que se espera, de acordo com suas perspectivas, é que o trabalhador saia de casa cedo, passe o dia inteiro em seu emprego e, ao cair da noite, volte para sua residência e jante com a família.

No âmbito microssocial da escola a lógica da organização social que permite a construção do bullying não é outra. Certos estudantes - seja por sua popularidade, seja pela força - impõem sobre os demais as regras que os beneficiam, que valorizam suas características sociais, evidenciando que detêm o poder para tanto. Assim, para eles, o padrão é ser bonito, saber conquistar os demais alunos e professores, mostrar suas habilidades na interação e não apenas chafurdar nos estudos.

Contudo, os que não se enquadram nesse padrão - os muito gordos, os muito magros, os feios, os nerds, os fracos, os que usam óculos ou aparelho dentário, os tímidos, entre outros - são estigmatizados e se tornam alvo de chacotas e violências físicas frequentes, tendo ainda que suportar todas as vicissitudes que o rótulo determina.

Outro nome importante na análise da temática é Goffman, cuja obra Estigma: notas sobre a manipulação da identidade deteriorada é paradigmática nesse sentido. ${ }^{296}$

Sua análise se compatibiliza com a feita por Becker, enquadrando-se, precipuamente, na terceira perspectiva estudada pelo autor, na qual ele passa a perquirir as consequências da imposição de uma etiqueta desabonadora. ${ }^{297}$

295 EINSTADTER, Werner J.; HENRY, Stuart. Criminological theory: an analysis of its underlying assumptions. 2. ed. Nova Iorque: Rowman \& Littlefield, 2006.

296 GOFFMAN, Erving. Estigma: notas sobre a manipulação da identidade deteriorada. Tradução de Márcia Bandeira de Mello Leite Nunes. 4. ed. Rio de Janeiro: LCT, 1988.

297 Conforme assevera Castro, os estudos de Goffman inserem-se, juntamente com o de Becker, no marco teórico da Criminologia da reação social, sendo que aquele representa a teoria do estigma e este a teoria 
Em sua obra Goffman menciona a existência de símbolos que transmitem informações sociais sobre o indivíduo. Todos eles estão ao alcance do público em geral e identificam uma característica positiva ou negativa do sujeito que o tem, evidenciando, pois, seu prestígio ou seu estigma, respectivamente.

Ao conceituar o estigma, o autor assevera que a expressão foi criada pelos gregos em referência à existência de marcas de identificação feitas no corpo dos indivíduos, visando destacar seus status social inferior.

Assim, criminosos, escravos e traidores eram marcados com cortes e com fogo, para que sua condição pudesse facilmente ser conhecida por todos, evitando-se, então, que pudessem fugir de sua sorte, ou melhor, de sua má sorte.

Hodiernamente, o estigma perdeu seu sentido único de marca corporal, já que ele refere-se também, e muito mais, à desgraça pessoal do sujeito, à sua qualidade como pessoa. Portanto, o vocábulo identifica tanto um aspecto corporal de alguém, o qual pode, por sua natureza, ser facilmente notado, quanto uma característica psíquica do agente, um elemento de sua concepção subjetiva.

Evidente, nesse contexto, que o estigma mantém-se irreparável como elemento identificador dos indivíduos, tendo se capilarizado nessa função ao abarcar, além dos sujeitos diferentes em sua constituição física, os que são considerados estranhos em virtude de sua personalidade ou maneira de ser.

É nesse sentido que Goffman ressalta a existência dos desacreditados e dos desacreditáveis. Os primeiros, por terem um estigma aparente, não podem, na interação social, esconder essa característica que os inferioriza. Os desacreditáveis, por sua vez, podem ocultá-la, ou pelo menos tentar fazê-lo, já que ela não é evidente. ${ }^{298}$

da rotulação ou da estigmatização. Cf. CASTRO, Lola Aniyar de. Criminologia da reação social. Tradução de Ester Kosovski. Rio de Janeiro: Forense, 1983.

298 GOFFMAN, Erving. Estigma: notas sobre a manipulação da identidade deteriorada. Tradução de Márcia Bandeira de Mello Leite Nunes. 4. ed. Rio de Janeiro: LCT, 1988. 
Note-se, então, que a categoria do estigmatizado é muito fluida, já que pode não existir objetivamente. A sociedade, assim como a escola, ao ordenar as pessoas, cria os diferentes, os que não se adaptam ao padrão que ela considera desejável. Essa diferença que estigmatiza "deriva da sociedade, porque, em geral, antes que uma diferença seja importante ela deve ser coletivamente conceptualizada pela sociedade como um todo”. 299

$\mathrm{Na}$ verdade, trata-se de um produto do projeto histórico-conflitivo das sociedades, o qual deve ser invocado visando à compreensão das razões pelas quais se estabeleceu, em dado momento, esse padrão que se utiliza para categorizar negativamente o outro. ${ }^{300}$

Criam-se expectativas em relação às pessoas e a seus comportamentos e quando o alvo desses anseios não corresponde eficazmente ao modelo preconcebido, tornase estigmatizado. Etiquetado o indivíduo, é comum seja ele identificado por apelidos difamatórios que evidenciam sua característica desabonadora.

Importante asseverar que a imposição dessa etiqueta é inconstante e arbitrária. Ela ocorre durante a interação, na dependência de um processo de negociação em que se identificam relações de poder, sendo a diferença entre estigmatizador e estigmatizado, por vezes, insignificante.

O mais forte, nesse diapasão, ganha a possibilidade de normatizar condutas e comportamentos e, assim, evidenciar o problema do outro, ressaltando, em contrapartida, sua superioridade. Logo, o estigma serve muito mais ao objetivo de evidenciar a normalidade do grupo que estigmatiza. Ele não representa, pois, necessariamente, o defeito do outro, e sim a adequação daquele que o impôs. Conforme assevera Goffman,

o estigma envolve não tanto um conjunto de indivíduos concretos que podem ser divididos em duas pilhas, a de estigmatizados e a de normais, quanto um processo social de dois papéis no qual cada indivíduo participa de ambos, pelo menos em algumas conexões e em algumas fases da vida.

299 GOFFMAN, Erving. Estigma: notas sobre a manipulação da identidade deteriorada. Tradução de Márcia Bandeira de Mello Leite Nunes. 4. ed. Rio de Janeiro: LCT, 1988. p. 134.

300 VISCARDI, Nilia. Disciplinamiento, control social y estigma: tres conceptos para una sociología del conflito: el caso de la violencia en el espacio escolar en Uruguay. Sociologias, Porto Alegre, v. 1, n. 1, p. 168-198, 1999. 
O normal e o estigmatizado não são pessoas, e sim perspectivas que são geradas em situações sociais durante os contatos mistos, em virtude de normas não cumpridas que provavelmente atuam sobre o encontro. ${ }^{301}$

Nesse sentido, a estigmatização reprime o medo da diminuição do próprio valor dos demais e cria uma união de maldição que tende a romper a solidariedade entre a sociedade e o estigmatizado. ${ }^{302}$

Para Goffman, há provas diretas dessa unidade, dessa semelhança eu/outro, normal/estigmatizado. Ressalta o autor que alguém fisicamente estigmatizado pode submeter-se a uma cirurgia plástica e seu atributo negativo desaparecerá, passando a enquadrar-se na categoria dos aceitos. Nesse sentido, defende que "se, então, a pessoa estigmatizada deve ser chamada de desviante, seria melhor que ela fosse denominada desviante normal”. 303

Tal assertiva pode ser comprovada nos casos de bullying. Conforme já se mencionou nesse excerto, Olweus confirmou que as vítimas das intimidações, ao tornaremse adultas, voltam a estabelecer relações sociais normalmente, uma vez que fora do local onde o estigma se originou ele desaparece, não é mais elemento importante na identificação social do sujeito.

Também o bullying praticado contra o bom aluno é exemplo maior desse argumento. Na escola essa característica pode ser encarada de forma negativa pelos demais estudantes, mas além desse ambiente ou desse momento específico ela é símbolo de prestígio social e sucesso profissional.

301 GOFFMAN, Erving. Estigma: notas sobre a manipulação da identidade deteriorada. Tradução de Márcia Bandeira de Mello Leite Nunes. 4. ed. Rio de Janeiro: LCT, 1988. p. 149.

302 BARATTA, Alessandro. Marginalidade social e justiça. Revista de Direito Penal, Rio de Janeiro, n. 2122, p. 5-25, jan.-jun. 1976.

303 GOFFMAN, Erving. Estigma: notas sobre a manipulação da identidade deteriorada. Tradução de Márcia Bandeira de Mello Leite Nunes. 4. ed. Rio de Janeiro: LCT, 1988. p. 142. 
Portanto, mais uma vez fica claro que “os papéis de estigmatizado e normal não são simplesmente complementares, mas exibem ainda paralelos e semelhanças surpreendentes”. 304

O estigma confere uma identidade a priori ao estigmatizado. Faz com que ninguém precise estabelecer contato com ele para que o conheça. É como se ele fornecesse todas as informações relevantes existentes sobre alguém, tornando a interação supérflua. Ele representa, conforme Goffman, a identidade social virtual do indivíduo, ou seja, os atributos que os outros imputam a ele, a qual pode ser incompatível com sua identidade social real, que se refere às características que ele realmente têm.

E assim, compelidos pela crença na existência de determinado estigma maligno no outro, “deixamos de considerá-lo criatura comum e total, reduzindo-o a uma pessoa estragada e diminuída”. 305

Em outros termos, assevera Viscardi que

a noção de estigma, que se coloca em jogo nas interações cara a cara, mostra o modo como diversos agentes manejam na vida cotidiana os marcos de referência que estruturam a situação em que se encontram e determinam o "normal" e o "anormal”, colocando em jogo ditos padrões em presença de um outro defeituoso, definido em termos negativos. ${ }^{306}$

Diante disso, a interação social torna-se bastante limitada, uma vez que somente dois grupos organizam-se para prestar apoio aos estigmatizados. Em primeiro lugar, os outros rotulados, seus coetâneos e, em segundo lugar, os que simpatizam com sua situação.

No que alude à relação estabelecida entre os estigmatizados, nem sempre a interação nesses casos é fácil, já que, muitas vezes, ela não é sequer livre, sendo apenas a

304 GOFFMAN, Erving. Estigma: notas sobre a manipulação da identidade deteriorada. Tradução de Márcia Bandeira de Mello Leite Nunes. 4. ed. Rio de Janeiro: LCT, 1988. p. 144.

305 Idem, ibidem, p. 12

306 VISCARDI, Nilia. Disciplinamiento, control social y estigma: tres conceptos para una sociología del conflito: el caso de la violencia en el espacio escolar en Uruguay. Sociologias, Porto Alegre, v. 1, n. 1, p. 168-198, 1999. p. 170. 
opção que restou ao indivíduo diante da indisposição dos demais para o contato social. Ratificando essa ideia, Goffman assevera que, em virtude da ambivalência da vinculação do indivíduo com seu grupo estigmatizado, haverá oscilações no seu apoio e sua participação em relação a ele, ciclos de incorporação e de rejeição. ${ }^{307}$

O grupo, que nas situações de interação social espontânea fornece a proteção e a identificação que os seus componentes almejam, ao envolver os estigmatizados, perde essa força e unidade. Isso porque o grupo de estigmatizados é composto de pessoas que não escolheram dele participar, mas foram compelidos a isso devido à inimizade dos demais, sendo que, em muitos caos, seus integrantes podem não ter nenhuma afinidade ou identificação entre si.

Ocorre que,

quando o indivíduo compreende pela primeira vez quem são aqueles que de agora em diante ele deve aceitar como seus iguais, ele sentirá, pelo menos, uma certa ambivalência porque estes não só serão pessoas nitidamente estigmatizadas e, portanto, diferentes da pessoa normal que ele acredita ser, mas também poderão ter os outros atributos que, segundo a sua opinião, dificilmente podem ser associados ao seu caso. ${ }^{308}$

Fato é que "a natureza de uma pessoa, tal como ela mesma e nós a imputamos, é gerada pela natureza de suas filiais grupais”. ${ }^{309}$ Assim, quando o sujeito se une aos demais excluídos, tal encontro serve para confirmar seu estigma e excluí-lo ainda mais do contato com os não estigmatizados.

Ademais, a relação do estigmatizado com os que se solidarizam com sua situação não é mais fácil. Há uma tendência de difusão do estigma aos que são próximos dos estigmatizados e esse fato dificulta grandemente a aproximação dos demais.

\footnotetext{
307 GOFFMAN, Erving. Estigma: notas sobre a manipulação da identidade deteriorada. Tradução de Márcia Bandeira de Mello Leite Nunes. 4. ed. Rio de Janeiro: LCT, 1988.

308 Idem, ibidem, p. 46.

309 Idem, p. 124.
} 
Por isso mesmo é que no caso do bullying escolar, os espectadores evitam sair em defesa dos vitimados temendo serem os próximos alvos das agressões. Eles preferem indignar-se em silêncio que publicizar a crítica ao comportamento dos agressores, os quais podem transformá-los nos próximos estigmatizados.

Não obstante os embaraços acima mencionadas acerca do convívio dos estigmatizados com os que se encontram na mesma situação que ele e com os simpatizantes, problema maior é lidar com os sujeitos ditos “normais” que não aceitam o estigmatizado. Nesse caso,

a simples previsão de tais contatos pode, é claro, levar os normais e os estigmatizados a esquematizar a vida de forma a evitá-los. Presumivelmente, isso terá maiores consequências para os estigmatizados, à medida que uma maior esquematização de sua parte será sempre necessária. ${ }^{310}$

Evidente, pois, que conferido o estigma negativo a alguém, essa pessoa passa a lidar com o dilema que cerca sua aceitação. Opta, então, por tentar corrigir sua situação ou romper com a realidade para fugir ao julgamento social que a inferioriza, optando pelo retraimento ou pela agressividade.

A vítima, pois, reage à rejeição dos demais isolando-se do convívio social ou mesmo optando por retribuir, por vezes de forma extrema e desproporcional como fazem algumas vítimas de bullying, a agressão que sofreu.

Independentemente do modo escolhido como defesa ou contra-ataque, toda essa situação afeta sobremaneira a carreira moral do estigmatizado, a concepção que ele tem de si próprio e o modo como ele se relaciona com o mundo ao seu redor. Fato é que, “faltando o feedback saudável do intercâmbio social quotidiano com os outros, a pessoa

310 GOFFMAN, Erving. Estigma: notas sobre a manipulação da identidade deteriorada. Tradução de Márcia Bandeira de Mello Leite Nunes. 4. ed. Rio de Janeiro: LCT, 1988. p. 22. 
que se autoisola possivelmente torna-se desconfiada, deprimida, hostil, ansiosa e confusa”. 311

Atribuído, pois, o rótulo, o indivíduo passa a interagir com ele, incorporando-o ao padrão de conduta que adota em sua vida cotidiana. ${ }^{312}$

Assim, Goffman assevera que a carreira moral do estigmatizado comporta duas fases distintas. Primeiro a pessoa assimila e incorpora as crenças dos normais e descobre o que significa ter um estigma e depois ela percebe que conta com um estigma e aprende detalhadamente as consequências de trazê-lo consigo.

Nesse diapasão,

as pessoas que têm um estigma particular tendem a ter experiências semelhantes de aprendizagem relativa à sua condição e a sofrer mudanças semelhantes na concepção do eu - uma "carreira moral” semelhante, que é não só causa como efeito do compromisso com uma sequência semelhante de ajustamentos pessoais. ${ }^{313}$

Na realidade, “a presença próxima de normais provavelmente reforçará a revisão entre autoexigências e ego, mas na verdade o auto-ódio e a autodepreciação podem ocorrer quando somente ele e um espelho estão frente a frente”. 314

Diante de todo o exposto, evidente a lógica da construção do processo de negociação das etiquetagens sociais, bem como a força destruidora que a identificação de alguém como indesejável, diferente, desviante acarreta na conjuntura da organização social e na relação que o estigmatizado estabelece com seus pares e consigo mesmo.

311 GOFFMAN, Erving. Estigma: notas sobre a manipulação da identidade deteriorada. Tradução de Márcia Bandeira de Mello Leite Nunes. 4. ed. Rio de Janeiro: LCT, 1988. p. 22.

312 SHECAIRA, Sérgio Salomão. Sistema de garantias e o direito penal juvenil. São Paulo: Revista dos Tribunais, 2008.

313 GOFFMAN, Erving. Estigma: notas sobre a manipulação da identidade deteriorada. Tradução de Márcia Bandeira de Mello Leite Nunes. 4. ed. Rio de Janeiro: LCT, 1988. p. 41.

314 Idem, ibidem, p. 17. 
Conforme se demonstrou, todo esse mecanismo de imposição de rótulos ocorre em diversos ambientes sociais, até mesmo na escola, onde culmina nas práticas de bullying entre os estudantes.

A escola é ambiente em que se encontram tanto a cultura tradicional quanto a cultura juvenil. Assim,

quando a precariedade absoluta foi ultrapassada e vínculos mais diversificados se criaram com o mundo exterior, o problema de um reconhecimento ligado a outras referências identitárias colocou-se com força. As dimensões culturais e raciais da identidade tornaram-se enfim visíveis. O preconceito e a discriminação passaram a constituir desde então experiências cotidianas dramáticas, à medida que recolocam permanentemente em questão a identidade individual. ${ }^{315}$

Ocorre que o colégio sempre foi considerado o local aonde os infantes vão para aprender, desenvolverem-se como cidadãos, formarem-se para, no futuro, alcançar o êxito social, mas justamente no seio dessa instituição sempre tida como segura que essas violências têm se manifestado.

Desse modo, é preciso compreender como a escola tem permitido, e talvez até fomentado, o conflito inter pares que acontece em seus domínios. É mister elucidar os tipos de relações que o ambiente escolar produz e quais suas consequências na formação dos jovens e na sua tarefa de educar.

315 PERALVA, Angelina. Violência e democracia: o paradoxo brasileiro. São Paulo: Paz e Terra, 2000. p. 65. 


\section{Capítulo 3}

\section{A ESCOLA SOB A PERSPECTIVA DA CRIMINOLOGIA CRÍTICA}

\subsection{Prevenção e repressão dos comportamentos desviantes: análise do controle social}

O controle social diz respeito a como cada sociedade rege a si própria, dirime seus conflitos e suas diferenças. ${ }^{316}$

Refere-se à capacidade de uma organização social regular a si mesma, o que se efetiva por normas, coercitivas ou não, emanadas de suas instituições, que visam a tornar a convivência social mais harmônica ou, pelo menos, possível.

Envolve, então, “todas as instituições, estratégias e sanções sociais que perseguem uma conformidade de conduta”. 317

Trata-se, segundo Castro, de “um conjunto de táticas, estratégias e forças para a construção da hegemonia, isto é, para a busca da legitimação ou garantia do consenso; ou, em caso de fracasso, para a submissão forçada dos que não se integram à ideologia dominante". 318

Importante perceber, contudo, que

não se conforma a noção de controle social em descrever e refletir um estado de coisa, senão que aposta na constituição e mantença de um tipo de organização social, implicando como consequência um compromisso com determinados valores e procedimentos. ${ }^{319}$

316 ANTILlanO, Andrés. Cambios en el concepto y uso del control social. Capítulo Criminológico, Maracaibo, v. 38, n. 1, p. 5-34, jan.-mar. 2010.

317 KAISER, Günter. Introducción a la Criminología. 7. ed. Tradução de José Arturo Rodríguez Núñez. Madrid: Dykinson, 1988. p. 110.

318 CASTRO, Lola Aniyar de. Criminologia da libertação. Tradução de Sylvia Moretzsohn. Rio de Janeiro: Revan, 2005. p. 153.

319 ANTILLANO, Andrés. Cambios en el concepto y uso del control social. Capítulo Criminológico, Maracaibo, v. 38, n. 1, p. 5-34, jan.-mar. 2010. p. 12. 
Nesse diapasão, entende-se que o controle social é produto do nível cultural de determinada sociedade. São as suas características liberais ou autoritárias que determinarão como se exercerá a contenção de sua população, como suas instituições interagirão entre si e qual delas terá preponderância na realização da citada tarefa, razão pela qual não pode ser ele estudado sem levar-se em consideração a conjuntura social e histórica na qual se insere.

Já nos primórdios da organização social, as condutas dos povos pré-letrados eram controladas por sanções mágicas e sobrenaturais e grupos primários, enquanto nas das sociedades urbanas o são por sanções legais e grupos secundários, como a escola, a Justiça e os meios de comunicação. ${ }^{320}$

Nesse contexto, mister evidenciar que “a complexidade é da essência do estudo das formas de controle social efetivadas em uma dada sociedade, notadamente se ela for desigual e heterogênea, como é a brasileira”. 321

A despeito de referir-se a modos de contenção de comportamentos, Bergalli assevera que o controle social

não foi originariamente - e, em consequência, não foi necessariamente a expressão de uma perspectiva política conservadora. Muitos sociólogos norte-americanos que empregaram o termo na primeira hora eram conspícuos socialistas; outros estavam adstritos a pontos de vista progressistas. $^{322}$

Na Criminologia moderna, o uso da expressão controle social remonta à segunda metade do século XIX nos Estados Unidos, com a chegada de grandes contingentes de população imigrada ao país.

O interesse em seu estudo, nesse momento, surgiu no âmbito da Sociologia norte-americana, numa tentativa de compreender a nova organização social que se conformava.

320 COSTA, Álvaro Mayrink da. Raízes da sociedade criminógena. Rio de Janeiro: Lumen Juris, 1997.

321 CARDOSO, Franciele Silva. A luta e a lida: estudo do controle social do MST nos acampamentos e assentamentos de reforma agrária. São Paulo: IBCCrim, 2012. p. 89.

322 BERGALLI, Roberto. Control social: sus orígenes conceptuales y usos instrumentales. Revista de Derecho Penal y Criminología, Madrid, n. 2, p. 173-184, 1992. p. 172. 
Desde a década de 1920 a cidade de Chicago, em virtude de seu acelerado desenvolvimento econômico e, consequentemente, da elevada oferta de trabalho produzida a partir daí, sofreu uma eclosão populacional abrupta, impulsionada pela vinda de imigrantes à cidade.

Tal êxodo foi tão expressivo, que em menos de um século, a população da cidade saltou de duzentas mil para três milhões e trezentas mil pessoas. ${ }^{323}$

Diante desse contexto a Escola de Chicago ${ }^{324}$ passou a perquirir como lidar com as consequências dessa situação que entendia ser de desorganização social.

Em outros termos, questionava como fazer conviver pacificamente pessoas que antes daquele momento nem sequer se conheciam e não dividiam crenças e valores comuns, já que cada qual provinha de contextos sociais distintos.

A ideia exposta pela Escola de Chicago cujo fundamento era de que a criminalidade e a desordem emanavam de uma patologia social, fez emergir dois grupos teóricos diversos. Um primeiro acreditava ser a delinquência consequência da falta de integração social informal em dada comunidade. De outro lado, as teorias da tensão, como a anomia e as subculturas delinquentes, para as quais a delinquência era a resposta de uma sociedade conflitiva que prioriza metas que não podem ser alcançadas por todos. ${ }^{325}$

Fato é que a Escola de Chicago inicia a problematização do controle social, que mais tarde se expande a partir do marco intelectual e do projeto ideológico do estruturalfuncionalismo. $^{326}$

SHAW, Clifford R; MCKAY, Henry D. Juvenile deliquency and urban areas. Chicago: University of Chicago, 1942.

324 A Escola de Chicago, considerada o berço da moderna Sociologia norte-americana, nasceu na Universidade de Chicago, onde se inaugurou no ano de 1892 o Departamento de Sociologia.

325 GARRIDO, Vicente; STANGELAND, Per; REDONDO, Santiago. Principios de criminología. 2. ed. Valência: Tirant lo blanch, 2001. Importante mencionar que as teorias funcionalistas da anomia e das subculturas delinquentes baseiam-se na ideia da existência de uma sociedade de consenso, na qual o conflito gera o crime, a desordem social.

326 BERGALLI, Roberto. Control social: sus orígenes conceptuales y usos instrumentales. Revista de Derecho Penal y Criminología, Madrid, n. 2, p. 173-184, 1992. 
Já nesse momento se evidencia a importância do binômio consenso-conflito na efetivação dos modos de controle e de organização social. Discutia-se, então, sobre que bases sociais o controle deveria ser realizado, se em uma sociedade baseada na coesão ou na coerção.

Note-se que essa discussão coaduna-se com as ideias mencionadas no início desse excerto acerca da polissemia e da complexidade do conceito. Conforme assevera Pavarini, o controle social pode ser conjugado de pontos de vistas contraditórios, como uma questão política ou como categoria sociológica.

Na primeira perspectiva, o termo é lido por meio de categorias politológicas e jurídicas, como poder, domínio, repressão e autoridade. Assim, o desviado é considerado um revolucionário, alguém que inovou no contexto social.

Já na segunda perspectiva, o controle social é interpretado sob o paradigma da integração social, da motivação social e da socialização.

Diante disso, revela o autor que

a dupla acepção de controle social e de desviação traduz, assim, dois pontos de vista opostos dos autores sociais: a primeira leitura conflitual, precisamente porque adverte o perfil autoritário da situação de controle, define também um espaço de liberdade em oposição ao controle; a segunda, justamente porque não percebe conflito algum, não pode sequer individualizar um espaço de liberdade como "outro diferente" daquele do controle. $^{327}$

Importante ainda asseverar que a discussão a respeito do pressuposto da organização das sociedades já existia desde os primórdios da sociedade.

No início da formação dos Estados soberanos, as estruturas de poder do Estado e da Igreja estavam umbilicalmente ligadas, no que se pode chamar de um primeiro momento de racionalização política. Já num segundo momento, “a consolidação do

327 PAVARINI, Masimo. Como resistir: control social y saber critico. Capítulo Criminológico, Maracaibo, n. 22, p. 33-53, 1994. p. 50. 
absolutismo ia de mãos dadas com as nascentes rivalidades entre os Estados e entre interpretações religiosas”, ${ }^{328}$ sendo mister a formulação de discursos criminológicos aptos a justificar a autoridade do monarca e sua consequente superioridade diante dos demais cidadãos do povo.

É, pois, nesse contexto que surge a primeira discussão acerca da antinomia justificadora do poder soberano, destacando-se as teorizações de Maquiavel e Hobbes, precipuamente em suas obras $O$ príncipe e Leviatã, respectivamente.

Para Hobbes, o que está na base política da sociedade é o consenso, baseado no sentimento de medo. É ele que faz com que os cidadãos cedam ao Estado seus direitos, na crença de ser ele capaz de zelar pela paz e pela ordem. Já para Maquiavel, as inter-relações humanas baseiam-se no conflito e na luta constante entre o soberano e seus súditos, pelo poder e pela liberdade.

Modernamente, a antinomia foi reintroduzida por Durkheim e Marx, sendo aquele representante do consenso e este do conflito. ${ }^{329}$

Defender que as sociedades têm como pressuposto o consenso significa crer que elas são modelos de participação sedimentados em valores e crenças comuns. Logo, a legislação é tida como representação dos anseios de todos os integrantes da organização social.

Nesse diapasão, a ordem social não precisa ser imposta pelo Estado ou pelas demais instituições sociais que compõem dada comunidade, já que é a própria coesão social que garante a mantença do sistema que é ratificado pelo interesse de todos que dele fazem parte. O controle, portanto, nesse modelo organizacional, baseia-se na estabilidade, na integração e na coesão dos membros da sociedade.

Parsons, teórico do consenso, considera-o uma precondição para a vida social, razão pela qual o conflito devia ser excluído ou reintegrado por meio do controle social.

\footnotetext{
328 ANITUA, Gabriel Ignacio. Histórias dos pensamentos criminológicos. Tradução de Sérgio Lamarão. Rio de Janeiro: Revan, 2008. p. 90.

329 A antinomia consenso-conflito representa um dos temas fundamentais da moderna Sociologia Criminal.
} 
Acredita que só o consenso é capaz de propiciar condições de vida adequadas aos cidadãos, uma vez que “a maior parte dos conflitos envolve consideráveis ingredientes do que se pode apropriadamente denominar comportamento aberrante”. 330

Na Criminologia, esse foi o modelo adotado pelas teorias da ecologia criminal, criada pela já mencionada Escola de Chicago, associação diferencial, anomia e subculturas delinquentes.

Para a teoria da ecologia criminal, a chave para a compreensão do comportamento aberrante e para a sua prevenção está no estudo da organização das cidades, no que se pode denominar sociologia da grande cidade, escolha que evidencia seu caráter empirista e pragmático.

A escola acreditava que a criminalidade ocorria nas áreas citadinas onde a desorganização social era mais proeminente, em virtude da falta de identidade e dos conflitos existentes no âmbito de dada comunidade, uma vez que tal desorganização perturbava a coesão social e fragilizava o controle social informal necessário para evitar a conduta indesejável.

Assim,

a deteriorização dos grupos primários (família etc.), a modificação qualitativa das relações interpessoais, que se tornam superficiais, a alta mobilidade e consequente perda de raízes no lugar de residência, a crise dos valores tradicionais e familiares, a superpopulação, a tentadora proximidade das áreas comerciais e industriais onde se acumula riqueza criam um meio desorganizado e criminógeno. ${ }^{331}$

Desse modo, visando à comprovação de sua teorização, a escola utilizou-se do modelo de crescimento de Chicago, identificando na cidade a existência de zonas de desenvolvimento diversas, representadas por cinco círculos concêntricos.

330 PARSONS, Talcott. Uma visão geral. Tradução de Octavio Mendes Cajado. In: PARSONS, Talcott (Org.). A sociologia americana. São Paulo: Cultrix, 1970. p. 381.

331 GARCÍA-PABLOS DE MOLINA, Antonio. O que é criminologia? Tradução de Danilo Cymrot. São Paulo: Revista dos Tribunais, 2013. p. 122. 
Para a teoria, quanto mais próximo da área central do círculo, maiores os índices de criminalidade, já que nessas regiões contíguas à zona industrial e nos locais de residência dos imigrantes recém-chegados, a desorganização social era maior.

A teoria da associação diferencial, de modo diverso, considerou que a razão para a ocorrência do crime não era a organização espacial das cidades, e sim as ideias.

De acordo com esse pensamento, os comportamentos, sejam eles criminosos ou pró-sociais, são aprendidos durante a interação social, mediante processos de comunicação. Assim, o contato constante e próximo com criminosos faz com que o sujeito aprenda a executar, bem como a justificar determinada conduta positivamente, estimulando-o, pois, a adotar o mesmo padrão comportamental.

Note-se que aqui a existência de pessoas com compreensões diferentes acerca das condutas que devem realizar, manifestação, pois, de um conflito cultural, é que produz a criminalidade.

As teorias da anomia e das subculturas delinquentes compartilham de mais caracteres comuns, uma vez que ambas podem ser consideradas funcionalistas.

Nas duas teorizações, as normas não representam exatamente os valores aceitos pelos integrantes do corpo social, são orientadas pelo conceito de classe, consideram o delito como resposta dos indivíduos aos conflitos sociais e defendem que os jovens praticam ilícitos movidos por estados emocionais negativos, como a frustração ou o ressentimento. $^{332}$

Mais especificamente, a teoria da anomia defende a normalidade e a funcionalidade do crime, fenômeno que se torna problemático apenas quando ocorre um aumento abrupto em suas manifestações.

332 ARAUJO, Fernanda Carolina de. A teoria criminológica do labelling approach e as medidas socioeducativas. 2010. 251f. Dissertação (Mestrado em Criminologia) - Faculdade de Direito, Universidade de São Paulo, [2010]. 
A partir desse pressuposto, desloca-se o foco do problema para o sistema social, a anomia nele causada, e não mais a organização das cidades ou às ideias.

Conforme teorização de Durkheim, ${ }^{333}$ existe uma situação de anomia quando a regulação dos comportamentos sociais, realizada pela lei, é inadequada ou incipiente, por não atender mais às demandas das sociedades modernas. Assim, trata-se da "ausência de normas sociais de referência que acarreta uma ruptura dos padrões sociais de conduta, produzindo uma situação de pouca coesão social”.334

Merton atualiza as ideias de Durkheim, transpondo-as para o contexto da sociedade moderna norte-americana. Para o autor, a criminalidade é causada quando a sociedade aponta os fins sociais que devem ser almejados por seus integrantes, mas não fornece a todos os caminhos para atingi-los, ou seja, quando a distribuição das oportunidades para alcançá-los é desigual. ${ }^{335}$

Nesse sentido, a anomia seria a contradição entre a estrutura social - os objetivos definidos como legítimos para o conjunto do corpo social - e a estrutura cultural -, definidora dos modos tidos como adequados na persecução dos objetivos estimulados. ${ }^{336}$

Por fim, coaduna-se com a compreensão consensual da sociedade a teoria das subculturas delinquentes, ${ }^{337}$ que a despeito das diferenças nas construções dela emanadas, evidencia, tal qual a teoria da anomia, os problemas sociais que se erigem diante dos conflitos manifestos no bojo da sociedade.

A ideia é que existem diversas representações culturais em uma comunidade, sendo que os sujeitos, por vezes, optam por aderir aos comportamentos reconhecidos por sua subcultura, mesmo que incompatíveis com aquilo que se determina conforme a cultura

333 Durkheim desenvolveu o conceito de anomia, mais detidamente, em suas obras A divisão do trabalho social (1893) e O suicídio (1897).

334 SHECAIRA, Sérgio Salomão. Criminologia. 4. ed. São Paulo: Revista dos Tribunais, 2012. p. 189.

335 MERTON, Robert K. Sociologia: teoria e estrutura. São Paulo: Mestre Jou, 1970.

336 Idem, ibidem, 1970.

337 Utiliza-se aqui a expressão subculturas delinquentes já que diversos autores debruçaram-se sobre a formulação de explicações culturalistas diversas ao fenômeno criminal, entre os quais podem ser citados Albert Cohen, Walter Miller, Richard Cloward e Lloyd Ohlin. 
dominante. Assim, considera-se que "na subcultura criminosa, as condutas desvalorizadas pela cultura jurídica e moral são legítimas”. 338

Cohen foi um dos grandes teóricos desse pensamento, tendo concentrado seu estudo na análise das gangues juvenis.

Para ele, nas sociedades modernas, os jovens provenientes dos estratos sociais mais desvalorizados conscientizam-se acerca da impossibilidade de alcançarem os objetivos idealizados pela sociedade, em virtude de sua origem desfavorável, optando, em contrapartida, por aderir a modelos comportamentais subculturais, mais condizentes com sua realidade. ${ }^{339}$

Destarte, os grupos que adotam determinada subcultura elegem suas próprias normas a serem respeitadas, negando legitimidade a outras aceitas pelo restante do corpo social. Caso o valor subcultural de seu grupo esteja vinculado à prática criminosa, é essa conduta que o sujeito irá adotar, independentemente de sua contrariedade com os valores sociais predominantes.

Evidencia-se, ante o exposto acerca das teorias do consenso, que a despeito das diferenças existentes entre elas em relação ao elemento impulsionador da criminalidade, o ilícito é sempre encarado como resultado da perturbação ao consenso. Assim, o desequilíbrio da ordem instituída é considerado elemento desintegrador apto a justificar o desvio.

O modelo conflitivo, por sua vez, defende que não existe coesão entre os integrantes da comunidade, sendo que o que fundamenta a realização do controle social é a coerção de uns pelos outros. Interessa-se não pelos elementos que reúnem e mantém os integrantes da sociedade, e sim pelo questionamento sobre quais as fontes de tensão produzidas na interação social e quais as desigualdades que perturbam a comunidade.$^{340}$

338 ANITUA, Gabriel Ignacio. Histórias dos pensamentos criminológicos. Tradução de Sérgio Lamarão. Rio de Janeiro: Revan, 2008. p. 498.

339 COHEN, Albert K. Delinquent boys. Londres: Routledge \& Kegan Paul, 1958.

340 COSTA, Álvaro Mayrink da. Raízes da sociedade criminógena. Rio de Janeiro: Lumen Juris, 1997. p. 285 
Ademais, sob esse referencial, "valores e ideias são considerados mais como armas para o conflito que como meios de integração. A sociedade é vista como um todo segmentado, com diferentes grupos lutando por recursos limitados”. 341

A sociologia do conflito caracteriza-se, pois, por incorporar o elemento poder na análise do controle social, sendo ele precípuo na realização do constrangimento. São, então, seus fundamentos a mudança, o conflito e o domínio. ${ }^{342}$

A esse respeito assevera Zaffaroni que

o homem sempre aparece em sociedade interagindo de maneira muito estreita com outros homens. Reúnem-se dentro da sociedade em grupos permanentes, alternativa ou eventualmente coincidentes ou antagônicos em seus interesses e expectativas. Os conflitos entre grupos se resolvem de forma que, embora sempre dinâmica, logra uma certa estabilização que vai configurando a estrutura de poder de uma sociedade, que é em parte institucionalizada e em parte é difusa.

O certo é que toda sociedade apresenta uma estrutura de poder, com grupos que dominam e grupos que são dominados, com setores mais próximos ou mais afastados dos centros de decisão. De acordo com essa estrutura, se "controla" socialmente a conduta dos homens, controle que não só se exerce sobre os grupos mais próximos a ele, aos quais se impõe controlar sua própria conduta para não debilitar-se. ${ }^{343}$

Diversos autores manifestaram sua compreensão social como eminentemente conflitiva. São os casos, por exemplo, do já citado Marx e de Dahrendorf. Para ambos o conflito é parte integrante da sociedade, contudo, em cada um deles, o seu fundamento é diverso.

Para Marx a coerção social tem por base o conflito de classes, enquanto para Dahrendorf sua causa é a distribuição diferenciada da autoridade.

341 GOMES, Candido Alberto. A educação em novas perspectivas sociológicas. 4. ed. São Paulo: EPU, 2005. p. 30.

342 BARATTA, Alessandro. El modelo sociológico del conflicto. In: ELBERT, Carlos Alberto (Dir.). Criminología y sistema penal. Montevidéu: Buenos Aires: IBdeF, 2004. p. 247-273.

343 ZAFFARONI, Eugenio Raúl; PIERANGELI, José Henrique. Manual de direito penal brasileiro: parte geral. 8. ed. São Paulo: Revista dos Tribunais, 2010. p. 58. 
Na visão de Marx o conflito na sociedade é apresentado sob a dialética da luta entre as classes sociais, entre burguesia e proletariado, ou capitalistas e trabalhadores.

Nessa disputa, o proletariado é dominado pelas instituições, como o Estado e a lei e o sistema de justiça dele emanados.

Já para Dahrendorf não é a luta entre as classes sociais, e sim a autoridade o elemento central do conflito. Nesse certame, o dominador deseja a manutenção da estruturação social que lhe confere autoridade, enquanto o outro anseia mudar a condição social que lhe priva dela.

Assim, em seu modelo de coerção social, a distribuição da autoridade nas associações é a causa da formação de grupos de conflito, uma vez que ela representa o poder, e, sendo dicotômica a relação que o produz, desencadeia a formação de dois grupos de conflito - os dominadores e os dominados. ${ }^{344}$

Diante disso, apesar da existência de diversos modelos de conflito, eles sempre desembocam na falta de homogeneidade das regras e dos valores dos indivíduos que conformam a sociedade.

Por essa perspectiva, evidencia-se que “as normas não são, se constroem”. ${ }^{345}$ Ou seja, a ordem social imposta pelas leis não representa os anseios da comunidade, a assunção dos valores almejados por todos, mas apenas um modelo imposto por certas pessoas - uma minoria destaca-se -, em condições privilegiadas de fazê-lo.

Nesse sentido, assevera Uriarte que

o controle é uma forma de exercício de poder na sociedade, desde os grupos mais ou menos perto dos centros de decisão, sobre os grupos mais ou menos afastados, que toma como base a conduta. Conforme se opere o controle social, determinados indivíduos são normais, disciplinados e

344 DAHRENDORF, Ralf. As classes e seus conflitos na sociedade industrial. Tradução de José Viegas. Brasília: Ed. UnB, 1982.

345 CHRISTIE, Nils. Una sensata cantidad de delito. Tradução de Cecília Espeleta e Juan Iosa. Buenos Aires: Del Puerto, 2004. p. 8. 
outros são desviados ou marginais; o controle social, pois, traça as estratégias de disciplina social. ${ }^{346}$

Também Larrauri, ao comparar os dois modelos de efetivação do controle social assinala que

parece que existe consenso em torno de determinados valores que
parecem responder às necessidades de toda a sociedade. Na realidade,
mais do que consenso há que se falar de imposição de uma cultura a
outras (sub) culturas e, mais que de representar interesses de toda a
sociedade, há que analisar que interesses concretos estão sendo
protegidos. $^{347}$

Por conseguinte, a ideia de consenso seria uma ilusão, algo impossível de se alcançar nas sociedades marcadas pelo multiculturalismo. Serviria ela apenas para mascarar a dominação que alguns exercem sobre os demais.

Coaduna-se essa maneira de compreensão do controle social com o desenvolvimento de uma Criminologia também baseada na conflitividade, a qual acredita ser ela inerente à estrutura social. Fato é que nas décadas de 1960 e 1970 a ciência criminológica sofreu profundas transformações associadas às mudanças no contexto social como um todo, as quais foram anunciadas pelas teorias labelling approach e crítica.

\section{Essa nova perspectiva}

iluminou a complexidade na configuração das relações sociais das sociedades pós-industriais, sobre a base do sistema de produção e distribuição dos recursos que as gesta; é dizer, a que deu lugar ao estudo analítico das formas de controle social em relação com os aspectos estruturais da sociedade. ${ }^{348}$

346 URIARTE, Carlos Elías. Control institucional de la niñez adolescencia en infracción: un programa mínimo de contención y límites jurídicos al Sistema Penal Juvenil (las penas de lós jóvenes). Montevidéu: Carlos Alvarez, 1999. p. 16.

347 LARRAURI, Elena. La herencia de la criminología crítica. 2. ed. Madri: Siglo Veintiuno de España, 2000. p. 79.

348 BERGALLI, Roberto. Control social: sus orígenes conceptuales y usos instrumentales. Revista de Derecho Penal y Criminología, Madrid, n. 2, p. 173-184, 1992. p. 176. 
Em um primeiro momento a teoria do labelling approach, em virtude de sua inovação em relação às teorias anteriores, passou a ser cunhada como teoria crítica. Mais tarde, com o surgimento de uma construção teórica que, utilizando-se das bases da anterior, avançou na análise do controle social, foi esta quem passou a receber a denominação crítica.

De todo modo, o labelling approach promoveu uma virada paradigmática nos estudos criminológicos por ter sido a primeira construção teórica a problematizar a atuação do controle social, elevando-o a categoria de produtor do desvio e da criminalidade.

Desmistifica-se o caráter ontológico do crime para considerá-lo resultado da imposição de um valor comungado pelos sujeitos que têm o poder de transformar seus anseios em regramentos sociais. Só é crime, pois, o comportamento que a lei eleva a tal categoria e só é criminosa a pessoa identificada nesses termos.

Note-se, em oposição, que como nada é criminoso em sua origem, para aqueles de dispõem do poder, toda conduta que creem indesejadas pode ser criminalizada para atender aos seus interesses ou às suas crenças, inclusive o molestamento de cetáceo, o uso da expressão couro sintético ${ }^{349}$ e o bullying, numa clara demonstração da perspectiva ideológica encerrada pelo controle.

Assim, assevera Andrade que

o labelling parte dos conceitos de "conduta desviada” e "reação social”, como termos reciprocamente interdependentes, para formular sua tese central: a de que o desvio e a criminalidade não são uma qualidade intrínseca da conduta ou uma entidade ontológica preconstituída à reação social e penal, mas uma qualidade (etiqueta) atribuída a determinados sujeitos através de complexos processos de interação social, isto é, de processos formais e informais de definição e seleção. ${ }^{350}$

349 SHECAIRA, Sérgio Salomão. Criminologia. 4. ed. São Paulo: Revista dos Tribunais, 2012.

350 ANDRADE, Vera Regina Pereira de. Do paradigma etiológico ao paradigma da reação social: mudança e permanência de paradigmas criminológicos na ciência e no senso comum. Revista Brasileira de Ciências Criminais, São Paulo, v. 4, n. 14, p. 276-287, abr.-jun. 1996. p. 280. 
Importante evidenciar que é apenas em virtude das colaborações prestadas por essa teoria que a ciência criminológica começa a adotar o controle social como seu objeto de estudo.

Antes do seu surgimento, conforme se evidenciou no presente excerto, as causas do crime eram buscadas na pessoa do infrator, nas áreas espaciais que constituem uma cidade, no sistema social, sendo que o sistema penal era considerado simplesmente como a resposta racionalizada diante da violação da norma.

A partir da emergência do labelling approach que esse entendimento é desmistificado. O sistema penal passa a ser encarado como produtor da criminalidade, como resposta seletiva e ineficaz ao crime, evidenciando-se a necessidade da compreensão e da crítica à sua atuação no âmbito criminológico.

Em razão de suas proposições, assevera Barreiras que

é difícil, em termos de ciência, falar em irreversibilidade, mas a verdade é que os enunciados legados pela teoria interacionista, se ignorados, conduzem, hoje, a estudos que desconsiderarão importantes variáveis criminológicas e limitarão o campo de estudo ao crime e ao criminoso. ${ }^{351}$

Diante desse desenvolvimento, então, é que se pode afirmar que o paradigma da reação social é condição necessária a uma Criminologia que pretende ser crítica. ${ }^{352}$

A despeito de seu protagonismo ao tratar certos conceitos, as limitações da teoria exigiram a construção de outra, capaz de compreender melhor as relações sociais que desembocam na criminalidade. Assim, assevera Santos que a teoria do labelling approach é

politicamente limitada e historicamente confusa: não compreende a estrutura de classes da sociedade, não identifica as relações de poder

351 BARREIRAS, Mariana Barros. Controle social informal $x$ controle social formal. In: SÁ, Alvino Augusto de; SHECAIRA, Sérgio Salomão. Criminologia e os problemas da atualidade. São Paulo: Atlas, 2008. p. 312.

352 ANDRADE, Vera Regina Pereira de. A ilusão da segurança jurídica: do controle da violência à violência do controle penal. 2. ed. Porto Alegre: Livraria do Advogado, 2003. 
político e de exploração econômica (e sua interdependência) do modo de produção capitalista e, definitivamente, não toma posição nas lutas fundamentais da sociedade moderna. ${ }^{353}$

No intuito de superar as críticas erigidas contra o labelling approach surge na década de 1970, simultaneamente nos Estados Unidos e na Inglaterra, a teoria crítica, que mais tarde se difundiu para o restante da Europa e também para a América Latina. ${ }^{354}$

Foi ela a primeira teorização a insistir na necessidade de se conhecer a totalidade do fenômeno social por ser ele elemento gerador da proibição e da desviação.

Desse modo, com o surgimento da teoria crítica, o estudo do controle social foi sofisticado, incluindo-se novos elementos em sua análise. Assim, “o qualificativo 'crítico' que caracteriza esse modelo criminológico centrou-se no questionamento acerca do funcionamento do controle social, fenômeno a que se reconhece natureza política”. ${ }^{355}$

Nessa perspectiva, o controle social é definido como “toda instância de regulação de corpos desde uma situação de poder, ou em concordância com ele, em benefício da ordem instituída”. 356

Note-se, pois, que sob a ótica desse referencial teórico, o controle visa à naturalização e normalização de uma ordem de coisas artificial. Desvela-se que as desigualdades não são naturais, mas socialmente construídas.

Fato é que

nos estudos criminológicos realizados a partir da virada paradigmática, empreendida pelas teorias do conflito, normalmente sobressai a

353 SANTOS, Juarez Cirino. A criminologia radical. Rio de janeiro: Forense, 1981. p. 17.

354 Importante destacar que apenas na década de 1970 os países europeus voltam a destacar-se na cena criminológica. Após os momentos iniciais da Criminologia, com as Escolas Clássica e Positivista, desenvolvidas na Europa nos séculos XVIII e XIX, respectivamente, os Estados Unidos apropriaram-se dos estudos da matéria ao uni-la à Sociologia Criminal na década de 1920.

355 SUXBERGER, Antonio Henrique Graciano. A inserção do controle social nas escolas criminológicas: do monismo social à criminologia crítica. Ciências Penais: Revista da Associação Brasileira de Professores de Ciências Penais, São Paulo, v. 3, n. 5, p. 214-230, jul.-dez. 2006. p. 227.

356 VISCARDI, Nilia. Disciplinamiento, control social y estigma: tres conceptos para una sociología del conflito: el caso de la violencia en el espacio escolar en Uruguay. Sociologias, Porto Alegre, v. 1, n. 1, p. 168-198, 1999. p. 178. 
preocupação em circunscrever a investigação à relação entre as formas de controle numa dada sociedade e a maior ou menor incidência da prática dos comportamentos desviados, os quais, no mais das vezes, também são definidos como crimes pela legislação penal aplicável, ainda que essa característica não seja imprescindível. Desta feita, os conceitos de controle social formulados ou adotados pelos criminólogos tendem a abarcar essa dupla condição: a tarefa da "normalização" da convivência social pressupõe a adoção de estratégias informais e formais de contenção dos desvios individuais ou mesmo de uma dada coletividade. ${ }^{357}$

Mister evidenciar que dentro da perspectiva crítica surgem diversas correntes de análise e de possíveis mudanças que deveriam ser efetivadas no sistema penal. Tais construções, desenvolvidas a partir de pressupostos comuns, tomam rumos absolutamente distintos, por vezes, incompatíveis entre si, como é o caso do neorrealismo de esquerda, que prega a recuperação do estudo das causas do delito, visando a denunciar as injustiças sociais que fundamentam a criminalidade; do direito penal mínimo, que busca o respeito aos preceitos de um direito penal como ultima ratio no exercício do controle; bem como do abolicionismo penal, cujo objetivo é a eliminação do todo ou de parte do sistema penal, uma vez que ele já demonstrou, reiteradamente, ser ineficiente.

No entanto, o que faz que todas essas propostas tenham alguma unidade é o fato de se insurgirem como contestadoras dos modelos criminológicos anteriores, precipuamente em relação às teorias consensuais.

Em realidade, a Criminologia crítica funda-se com uma prática e um discurso contra a Criminologia positivista e seu modelo consensual de sociedade; erige-se contra a dogmática penal e sua pretensa imparcialidade na escolha dos bens jurídicos merecedores de tutela penal; ressalta o funcionamento seletivo do sistema punitivo; assevera a funcionalidade do sistema penal para a manutenção do sistema capitalista, bem como demonstra a relação de dependência existente entre o sistema político-econômico e o sistema de controle social punitivo. ${ }^{358}$

357 CARDOSO, Franciele Silva. A luta e a lida: estudo do controle social do MST nos acampamentos e assentamentos de reforma agrária. São Paulo: IBCCrim, 2012. p. 95.

358 CARVALHO, Salo de. Criminologia crítica: dimensões, significados e perspectivas atuais. Revista Brasileira de Ciências Criminais, São Paulo, v. 104, n. 21, p. 279-303, set.-out. 2013. 
Em virtude das mencionadas constatações, para Carvalho, essa nova Criminologia tem relevância como discurso de resistência ao punitivismo e por sua estreita relação com a proteção dos direitos humanos. ${ }^{359}$ Diante dessa proposta, defende Bergalli que o controle social, o qual entende contrapor-se ao controle coercitivo, exercido pelaa força, pode ser concebido como

um compromisso valorativo que repousa sobre dois elementos: a redução da coerção, ainda que ele reconheça a subsistência de elementos irredutíveis de coerção em um sistema de legitimidade política, e a eliminação da miséria humana, ainda que este também imponha reconhecer a persistência de um crescente grau de desigualdade. Se deveria mencionar assim mesmo um terceiro elemento, qual é o compromisso de redefinir as metas sociais com o fim de incrementar o papel da racionalidade, ainda que esta deveria ser considerada inerente aos primeiros. ${ }^{360}$

Mais recentemente o controle social vive um ressurgimento, compatível com as transformações e as crises das sociedades pós-modernas. Logo, identifica-se que há "uma relação direta entre a crise das sociedades contemporâneas, o processo de globalização neoliberal, com sua reestruturação econômica, e as novas formas de tratamento das questões sociais, culturais e políticas”. 361

Nesse contexto, inclusive, há os que objetam a persistência acerca da dicotomia entre os elementos do consenso e do conflito como suportes da organização social, acreditando que teorizações de caráter geral são incompatíveis com a liquidez da pósmodernidade.

Contrariamente, porém, há de se ressaltar que

no Hemisfério Sul, em muitos lugares e para muitos públicos, a Revolução Industrial do século XIX ainda não chegou. Pode-se dizer que muitos grupos ainda não ingressaram sequer na modernidade, enquanto o

359 CARVALHO, Salo de. Criminologia crítica: dimensões, significados e perspectivas atuais. Revista Brasileira de Ciências Criminais, São Paulo, v. 104, n. 21, p. 279-303, set.-out. 2013.

360 BERGALLI, Roberto. Control social: sus orígenes conceptuales y usos instrumentales. Revista de Derecho Penal y Criminología, Madrid, n. 2, p. 173-184, 1992. p. 177.

361 DORNELLES, João Ricardo. Ofensiva neoliberal, globalização da violência e controle social. Discursos Sediciosos: crime, direito e sociedade, São Paulo, v. 7, n. 12, p. 119-137, 2002. p. 119. 
mundo em rede, cada vez mais tentacular, caminha para a pósmodernidade. As metanarrativas da modernidade, na verdade concebidas em sociedades industriais, talvez nunca tenham sido suficientes para explicar as nossas particularidades. ${ }^{362}$

Conforme analisa Garland, o embate entre liberdade e controle caracterizou os últimos trinta anos. Enquanto a dinâmica da pós-modernidade enfatizou a liberdade, a abertura, a mobilidade e a tolerância, a cultura reacionária prioriza o controle, a restrição, o confinamento e a condenação. ${ }^{363}$

Assim, tem-se que

o controle social parece ocupar novamente mas de uma maneira absolutamente distinta, um lugar privilegiado nas discussões em torno da ordem e da infração. Tornou-se noção ateórica, explicação de alcance limitado, voz modesta, mas ganhou em troca prestígio e espaço como justificação e fundamento (pobre, mas eficaz) do conjunto de mudanças que operam no contexto das políticas de segurança. ${ }^{364}$

Nas palavras de Garland,

as estratégias atuais de controle do crime guardam uma certa congruência, um certo "ajuste” com as estruturas da sociedade pósmoderna. Elas representam um tipo particular de resposta, uma adaptação particular aos problemas específicos de ordem social produzidos pela organização social pós-moderna. Mas tais políticas não são inevitáveis. ${ }^{365}$

O exagerado temor do crime e a sensação de que ele está cada vez mais perto colaboram sobremaneira com as citadas mudanças.

362 GOMES, Candido Alberto. A educação em novas perspectivas sociológicas. 4. ed. São Paulo: EPU, 2005. p. 89-90.

363 GARLAND, David. A cultura do controle: crime e ordem social na sociedade contemporânea. Tradução de André Nascimento. Rio de Janeiro: Revan, 2008. p. 420.

364 ANTILLANO, Andrés. Cambios en el concepto y uso del control social. Capítulo Criminológico, Maracaibo, v. 38, n. 1, p. 5-34, jan.-mar. 2010. P. 22.

365 GARLAND, David. A cultura do controle: crime e ordem social na sociedade contemporânea. Tradução de André Nascimento. Rio de Janeiro: Revan, 2008. p. 425. 
Desmistificando a pertinência do receio que tem se expandido nas sociedades pós-modernas, analisa Batista que

entendemos o medo não como consequência de tempos difíceis, mas como uma opção ideológica e estética, uma maneira de interpretar a realidade que se tornou hegemônica na vitória política de um discurso e de uma estética conservadora contra os nossos desejos de nação. ${ }^{366}$

Assim, “embora as estruturas de controle tenham sido transformadas em importantes aspectos, a mudança mais significativa se deu no nível da cultura, que dá vida a estas estruturas, ordena seu uso e cunha seu significado". ${ }^{367}$ A cultura do medo, da insegurança, da impunidade, muito mais imaginárias do que reais, é que têm justificado as pretensões da realização e da exacerbação do controle social.

Nesse contexto, também, a Criminologia acadêmica perdeu seu lugar na análise e interpretação da criminalidade para políticos, jornalistas e ativistas, hodiernamente tidos como pessoas qualificadas para discutir o fenômeno. ${ }^{368}$

O controle social é um mecanismo extenso e multifacetado de prevenção e representação de comportamentos. Sendo assim, cabe identificar por que mecanismos exerce-se tal tarefa.

\subsubsection{Formas de exercício do controle social}

Ross distingue o controle social em ético e político, sendo a preponderância de cada qual variável de acordo com a sociedade considerada. O primeiro seria o realizado pelas associações religiosas, pela arte ou pela opinião pública, cuja coerção baseia-se mais

366 BATISTA, Vera Malaguti. A arquitetura do medo. Discursos Sediciosos: crime, direito e sociedade, São Paulo, v. 7, n. 12, p. 99-106, 2002. P. 104.

367 GARLAND, David. A cultura do controle: crime e ordem social na sociedade contemporânea. Tradução de André Nascimento. Rio de Janeiro: Revan, 2008. p. 376.

368 YOUNG, Jock. A sociedade excludente: exclusão social, criminalidade e diferença na modernidade recente. Tradução de Renato Aguiar. Rio de Janeiro: Revan, 2002. 
em um sentimento do que em sua utilidade. O segundo, por sua vez, exercido pela lei e pela educação, tem por referência o poder de fiscalização, de polícia. ${ }^{369}$

Atualmente, essas espécies de coerção social, com algumas modificações, são aludidas pelas expressões controle social informal e formal, respectivamente. O primeiro refere-se à fiscalização realizada pela sociedade civil e suas instituições, enquanto o segundo é o exercido pelas agências de controle ligadas ao poder do Estado de punir, as quais, em razão disso, operam a criminalização ou convergem na sua produção. Trata-se, pois, do sistema penal.

Eles podem ser denominados também controle reativo e proativo, apesar de essa denominação ser menos utilizada. O controle proativo visa a prevenir o comportamento desviante, diminuindo o uso do controle reativo, que exsurge apenas após a prática ilícita.

Nesse diapasão, assevera Garland que “devemos ter em mente, portanto, que o campo de controle do crime envolve tanto as atividades oficiais de ordenamento social como as atividades de atores e agências privadas, nas práticas e rotinas ordinárias”, 370 razão pela qual, “ a oposição de 'modelos' e ‘sanções' surge como problema inerente ao tema”. ${ }^{371}$

Conforme evidencia Zaffaroni, é amplíssimo o âmbito do controle social, e por isso, quem pretender estudá-lo, não deve se ater ao sistema de controle social institucionalizado, ao sistema penal ou à letra da lei, e sim perquirir, entre outros aspectos, acerca da estrutura autoritária ou não das famílias, sobre a orientação adotada na medicina e a respeito dos métodos pedagógicos, do controle ideológico dos textos e da liberdade de cátedra referentes à educação, seja ela efetivada pela escola ou pela universidade, uma vez

369 ROSS, Edward A. Social control. In: COSER, Lewis A.; ROSENBERG, Bernard (Ed.). Social theory: a book of readings. Nova Iorque: Macmillan, 1957.

370 GARLAND, David. A cultura do controle: crime e ordem social na sociedade contemporânea. Tradução de André Nascimento. Rio de Janeiro: Revan, 2008. p. 48.

371 SICA, Ana Paula Zomer. Prevenção Criminal: análise de políticas extrapenais. Rio de Janeiro: Lumen Juris, 2009. p. 76. 
que "quem quiser formar uma ideia do modelo de sociedade com que depara, esquecendo esta pluridimensionalidade do fenômeno de controle, cairá em um simplismo ilusório”, ${ }^{372}$

Ademais, mister salientar que muitas vezes o exercício desse controle é feito de maneira mascarada, não evidente, sem deixar claro seus reais objetivos. Nesse sentido, assevera mais uma vez Zaffaroni que

este fenômeno de ocultamento do controle social é mais pronunciado nos países centrais do que nos periféricos, onde os conflitos são mais manifestos. De qualquer modo, inclusive nos países periféricos, o controle social tende a ser mais anestésico entre as camadas sociais mais privilegiadas e que adotam os padrões de consumo dos países centrais. ${ }^{373}$

Numa perspectiva conflitiva, a análise dicotômica dessas duas maneiras de controle - formal e informal - serve para fundamentar o potencial desviante de cada um desses mecanismos, já que ambos operam de maneira autoritária e em conjunto.

Fato é que

as instituições formais de controle do crime tendem a ser reativas e adaptáveis. Elas operam buscando complementar os controles sociais da vida comum, apesar de muitas vezes interferirem nesses controles sociais, prejudicando sua efetividade. Como a vida cotidiana se modifica, suas mudanças frequentemente trazem consequências para a estrutura dos controles informais, que podem, por seu turno, trazer problemas para o funcionamento e a efetividade das instituições de controle formal. [...] É comum nossa atenção se voltar apenas às instituições estatais, descuidando das práticas sociais, das quais a ação estatal depende. ${ }^{374}$

Importante, então, perceber que, quaisquer que sejam elas,

as instituições de controle social são explicáveis como estruturas de autoridade e de disciplina da formação social: a religião, na sociedade

372 ZAFFARONI, Eugenio Raúl; PIERANGELI, José Henrique. Manual de direito penal brasileiro: parte geral. 8. ed. São Paulo: Revista dos Tribunais, 2010. p. 59.

373 Idem, ibidem, p. 58-59.

374 GARLAND, David. A cultura do controle: crime e ordem social na sociedade contemporânea. Tradução de André Nascimento. Rio de Janeiro: Revan, 2008. p. 47/48. 
medieval, o mercado - cujos fios invisíveis ligam o trabalhador à classe capitalista -, a prisão, a escola, a família etc., no capitalismo. ${ }^{375}$

Explanadas as grandes classificações do controle social, mister elucidar em que consiste cada uma delas e como elas operacionalizam sua tarefa de prevenção e repressão dos atos indesejados.

\subsubsection{Controle social formal}

A característica precípua do controle social formal refere-se à participação estatal em sua realização. Assim, trata-se do controle efetuado por alguma instituição que compõe o Estado, exercido por pessoas que têm tal tarefa como atividade profissional e que, por ser institucionalizado, dispõe de modos e procedimentos de antemão estabelecidos.

Logo, torna-se fundamental perquirir o papel desempenhado pelo Estado na realização do controle social formal.

Em um primeiro momento, quando da apreensão do controle social pela Escola de Chicago, a função do Estado em sua realização não era considerada significativa, já que, conforme exposto neste Capítulo, o problema estava localizado diretamente na convivência social. Apenas mais tarde é que a sua atividade passou a ser importante, tendo ele adquirido, inclusive, prevalência no exercício da coerção.

Nesse diapasão, assevera Suxberger que

a época primária de desenvolvimento da categoria "controle social” caracterizou-se por tendências oscilatórias opostas quanto a estatizar ou não a função controladora da sociedade. No surgimento do conceito sociológico de controle social, predominou a ideia da completa separação entre o controle social e a intervenção estatal (Ross e a Escola de Chicago). Todavia, as condições econômico-sociais dos Estados Unidos na década de 1930 levaram a uma mudança radical na interpretação da categoria “controle social” e suas relações com o aparato estatal,

375 SANTOS, Juarez Cirino. A criminologia radical. Rio de janeiro: Forense, 1981. p. 113. 
modificação esta caracterizada pelo reconhecimento da capacidade organizativa do Estado por meio do direito, este último alçado a elemento controlador por excelência (corrente estrutural-funcionalista). ${ }^{376}$

Assim, após um período em que sua função de controle social é relegada, com o desenvolvimento das teorias criminológicas de corte funcionalista o Estado passou a ganhar importância como instrumento de contenção de comportamentos, ainda que exercendo papel marginal. Contudo, é a partir da década de 1960, nos estudos realizados pelo labelling approach que, conforme elucidado no item anterior, sua atuação passa a ser compreendida como fundamental na realização do controle social.

É em virtude da ingerência estatal que o controle adquire forte carga negativa, passando a ser encarado como uma intervenção deliberada no comportamento do indivíduo. ${ }^{377}$ Nesse diapasão, nas palavras de Vieira: “violência e arbitrariedade. Este é o modo pelo qual o Estado e a sociedade têm tentado suprimir o problema da desobediência ao direito, deixando sem resolver os problemas sociais”. 378

É também pela sua ação coercitiva que se desintegra a ideia do consenso como basilar da conformação social.

No âmbito criminal, o controle social formal é exercido pelo sistema penal, ${ }^{379}$ conformado pelo Direito Penal, pelas polícias, pelo Ministério Público, pelos Tribunais, pelas prisões, pelos hospitais psiquiátricos, bem como pelo Sistema Penal Juvenil.

376 SUXBERGER, Antonio Henrique Graciano. A inserção do controle social nas escolas criminológicas: do monismo social à criminologia crítica. Ciências Penais: Revista da Associação Brasileira de Professores de Ciências Penais, São Paulo, v. 3, n. 5, p. 214-230, jul.-dez. 2006. p. 229.

377 ANTILlano, Andrés. Cambios en el concepto y uso del control social. Capítulo Criminológico, Maracaibo, v. 38, n. 1, p. 5-34, jan.-mar. 2010.

378 VIEIRA, Oscar Vilhena. Los límites de la autoridade del derecho. In: VALDEZ, Antonio Garzón et al. (Orgs.). Violencia y derecho. Buenos Aires: Editores Del Puerto, 2004. p. 333.

379 Para Zaffaroni, a denominação sistema penal obedece a uma convenção, mas na realidade, ele não pode ser considerado efetivamente um sistema em razão da diversidade de origem social e treinamento das pessoas que o integram, da compartimentalização das agências que o compõem, da dependência que têm de distintas autoridades e agências estatais, bem como da disparidade de critérios de eficácia com que operam. Cf. ZAFFARONI, Eugenio Raúl. Criminología: aproximación desde un margen. Colômbia: Temis, 1993. 
Ainda no interior dessa organização, pode-se identificar a existência de um sistema penal estrito, do qual emana um discurso claramente punitivo, tal qual o direito, o processo penal e a execução da pena, bem como de um sistema penal em sentido amplo, composto dos hospitais psiquiátricos e das instituições de internação de adolescentes, cujo discurso não é punitivo, a despeito de sua atuação certamente o ser.

No que se refere à área da Justiça da Infância e Juventude, é possível perceber que sua operacionalização conta com algumas peculiaridades em cotejo com a disciplina destinada aos adultos.

O sistema de controle funciona mais informalmente para os jovens, o que macula as ideias de correção dos aspectos formais desse sistema, sendo ainda que a mencionada informalidade dificulta a identificação das violações de direitos verificadas na prática. $^{380}$

De todo modo, a maior característica do controle exercido nos moldes penais, seja ele destinado a adolescentes ou adultos, refere-se ao fato de ele conter as sanções mais gravosas que podem ser aplicadas a uma pessoa, as quais incluem desde uma pequena limitação aos direitos do indivíduo, passando pela privação prolongada de sua liberdade ou mesmo pela decretação de sua morte.

Entretanto, tem-se que esse tipo de controle é menos efetivo e produz consequências mais gravosas do que os problemas que pretende resolver, uma vez que a contrapartida penal está mais para uma resposta do que para a solução de um conflito social. ${ }^{381}$ Logo, “a criminalidade, como a penalidade, não só são artificiais, senão que inclusive já perderam toda especificidade: são somente recursos sociais em sua máxima valoração simbólica, como o dinheiro”. 382

\footnotetext{
380 URIARTE, Carlos Elías. Control institucional de la niñez adolescencia en infracción: un programa mínimo de contención y límites jurídicos al Sistema Penal Juvenil (las penas de lós jóvenes). Montevidéu: Carlos Alvarez, 1999.

381 Idem, ibidem.

382 PAVARINI, Massimo ¿A donde vamos? Capítulo Criminológico, Maracaibo, n. 22, p. 3-18, 1994. p. 11.
} 
Hulsman ratifica essa ideia em sua parábola acerca de uma situação hipotética em que um estudante, que habita com mais quatro colegas seus, quebra o televisor da residência.

Certamente que o ocorrido não agrada a nenhum dos demais estudantes, mas cada um deles propõe uma maneira diversa de solucionar o conflito.

Um deles alvitra como solução para o feito a expulsão do autor do dano da república; o segundo estudante propõe que seu colega repare os prejuízos causados com a danificação do objeto; o terceiro defende que o ocorrido demonstra que o colega que quebrou a televisão é enfermo e precisa de tratamento e o último, por sua vez, entende que deve haver algo errado na pequena comunidade por eles constituída que possibilitou que aquele fato ocorresse, devendo todos, juntos, fazerem um exame de consciência. ${ }^{383}$

Note-se, pois, que diante da dada situação, diversas soluções foram propostas: a punição, a reparação dos prejuízos, o tratamento do autor ou ainda a conciliação entre os envolvidos. O que o sistema penal faz é apenas escolher uma das possíveis respostas e torná-la regra em seu sistema, mesmo que a eleita não seja a mais eficaz nem a mais barata, tal qual ocorre com a sanção de reclusão.

De acordo com a tese exposta por Rusche e Kirchheimer no livro Punição e estrutural social, a contrapartida penal é eleita de acordo com uma racionalidade meramente econômica. Portanto, é esse elemento exterior ao sistema penal que justifica as sanções escolhidas em cada momento histórico considerado.

Para demonstrar essa tese a obra inicia-se com o estudo da pena na Baixa Idade Média. Nesse período, a indenização e a fiança foram as maneiras de punição eleitas, sendo elas graduadas de acordo com a classe social do infrator e de sua vítima. Posteriormente, essas penalidades foram substituídas por castigos corporais, visando a alcançar os sujeitos considerados delinquentes pertencentes às classes mais desfavorecidas social e economicamente.

383 HULSMAN, Louk; CELIS, Jacqueline Bernat de. Penas perdidas: o sistema penal em questão. Tradução de Maria Lúcia Karan. Rio de Janeiro: Luam, 1993. 
Com o advento do capitalismo o regime duplo de castigos corporais e fiança é mantido. Entretanto, o Direito Penal torna-se mais intolerante em relação aos crimes patrimoniais e as diferenças no tratamento penal de ricos e pobres se aprofunda, já que o primeiro paga quando condenado por um crime, enquanto contra o pobre expande-se a pena de morte e de mutilação grave.

Para os autores, o recrudescimento da punição nesse período tem uma justificação de fundo social e econômico. Para eles,

todo o sistema penal da Baixa Idade Média deixa claro que não havia escassez de força de trabalho, pelo menos nas cidades. Como o preço da mão de obra baixou, a valorização da vida humana tornou-se cada vez menor. A luta renhida pela sobrevivência moldou o sistema penal de tal forma que este se constituiu num dos meios de prevenção de grandes crescimentos populacionais. ${ }^{384}$

Durante o Mercantilismo, a realidade social altera-se sobremaneira, mais uma vez. Com o surgimento dos grandes centros urbanos, a mão de obra fazia-se cada vez mais necessária, enquanto o crescimento demográfico aumentava de maneira rarefeita, em virtude de guerras religiosas e de distúrbios internos ocorridos no século XVI.

Os métodos de punição novamente adaptaram-se à nova demanda social apresentada, sendo que a possibilidade de explorar o trabalho dos presos passou a ser observada pelo sistema penal, o qual adotou a escravidão nas galés, a deportação e a servidão penal por meio de trabalhos forçados como modos de repressão à criminalidade.

Na tentativa de controlar os trabalhadores, o Estado percebeu nessa investida que conseguia fiscalizar melhor os sujeitos que exerciam profissões ilegais - como os mendigos e as prostitutas - e os que dependiam de sua assistência - loucos, órfãos e viúvas.

A falta de mão de obra, bem como o custo representado pela mendicância, fizeram com que o Estado endurecesse sua posição em relação a esses improdutivos,

384 RUSCHE, Georg; KIRCHHEIMER, Otto. Punição e estrutura social. Tradução de Gizlene Neder. 2. ed. Rio de Janeiro: Revan, 2004. p. 39. 
criando, no fim do século XVII, uma instituição com o objetivo de abrigá-los, as casas de correção, limpando, assim, as cidades e modificando sua estética e dando uma destinação útil a esse grupo.

Nelas, misturavam-se os princípios das casas de assistência aos pobres, das oficinas de trabalho e das instituições penais, para se criar um ambiente cujo objetivo precípuo era transformar mendigos, prostitutas, ladrões, desempregados, ou seja, os indesejáveis, em força de trabalho útil. Com vistas a alcançar seu propósito, essas casas adotavam a ideologia calvinista do trabalho como a essência da vida e utilizavam-se da religião para inculcar em seus internos a disciplina e a disposição para o labor.

Por certo foi determinante para o surgimento e a mantença das casas de correção a expectativa de lucros sobre o trabalho ali realizado, sendo esta faceta mais importante do que o estímulo ético ao trabalho.

Ocorre que com o fim do Mercantilismo, em razão do crescimento populacional e da introdução das máquinas a vapor nas fábricas, formou-se um excedente de trabalhadores, que antes eram supervalorizados em virtude de sua carência. Essa nova conjuntura gerou um grande incremento da pobreza e o aumento da população nas casas de correção, causando problemas de superlotação e de precariedade de condições de sobrevivência.

A mendicância, por conseguinte, que antes era punida com a privação da liberdade nas casas de correção, deixou de ser criminalizada e o labor deixou de ser considerado um dever dos cidadãos para tornar-se um direito.

Diante disso, não havia mais o que fazer a não ser extinguir as casas de correção. Economicamente, a mantença dessas instituições tornou-se desnecessária, já que, nesse momento, era menos custosa a contratação de trabalhadores livres.

Foi no Iluminismo, após findas as casas de correção, que o cárcere solidificouse como a mais importante maneira de punição implementada por meio do sistema penal. Por essa razão Rusche e Kirchheimers defendem que “os fundamentos do sistema 
carcerário encontram-se no mercantilismo; sua promoção e elaboração foram tarefas do Iluminismo". 385

Com a solidificação e a expansão do cárcere, aliadas à falta de investimentos para a sua mantença, o que se tinha nesse ambiente era uma situação de superpopulação, mortandade, falta de alimentação e de assistência médica.

Mesmo assim, acreditava-se que as condições de sobrevivência nas cadeias eram muito boas e que inúmeros sujeitos delinquiam visando a habitá-la. Concordou-se, então, que aos internos não deveria ser dado nada além do mínimo, que eles deveriam viver em condições piores do que a classe subalterna livre.

A mão de obra dos encarcerados já não era necessária ao mercado de trabalho e o labor foi reintroduzido no cárcere não mais como um meio de obtenção de lucro, e sim como modo de punição. Disseminou-se a ideia de que o sofrimento da privação de liberdade era muito pouco significativo e que os reclusos deveriam sofrer mais do que qualquer outro cidadão, sendo esse sofrimento implementado por meio da tortura, da fome, da humilhação, dos trabalhos forçados - inúteis e insalubres - e do isolamento celular.

A partir da segunda metade do século XIX, a vida das classes subalternas conta com significativas melhoras. Entre outros fatores, a elevação de salários, a baixa taxa de natalidade, a industrialização, o desenvolvimento de meios de transporte ligando diferentes regiões e países e a remediação da pobreza pelos governos são responsáveis pela mudança.

A relativa tranquilidade do cenário econômico e social culminou numa queda dos índices de criminalidade no período. O encarceramento desmedido e irracional tornouse indesejado e a pena passou a ser aplicada com vistas à reabilitação do condenado: o preso deveria ser curado, uma vez que o crime era considerado um problema médicopsicológico.

Porém, já no início do século XX, as políticas penais do fascismo e do nacional-socialismo destruíram as garantias conquistadas pelo liberalismo. O que importa

385 RUSCHE, Georg; KIRCHHEIMER, Otto. Punição e estrutura social. Tradução de Gizlene Neder. 2. ed. Rio de Janeiro: Revan, 2004. p. 109. 
nesse momento é a realização dos objetivos punitivos do Estado, tornando-se descartáveis as garantias conquistadas pelos cidadãos ao longo da história da punição.

Os esforços do Estado convergiram para a introdução de uma política punitiva mais severa e brutal, baseada em princípios pretensamente educacionais.

A falácia é que tudo se justifica no cárcere, pois ele existe, somente, para reeducar os presos.

Também é nesse sentido a teorização proposta por Massimo e Pavarini ao defenderem que o cárcere foi criado com o objetivo precípuo de transformar reclusos em proletariados, sendo que as variações no sistema de produção refletem-se também no da prisão: se no mercado livre a força de trabalho excede a demanda, o cárcere transforma-se num local de destruição da força de trabalho; em contrapartida, na situação contrária, há um esforço no sentido do emprego útil da força de trabalho dos encarcerados. ${ }^{386}$

Desvendados os mecanismos de escolha da resposta penal, importante também perceber com Uriarte que é uma construção que se realiza por meio do discurso que determina certo problema social, seus limites e seus conteúdos. Sendo assim, assevera que “a construção de uma situação social a institui, a apreende, a identifica, permite operá-la e diagnosticá-la”. 387

Por óbvio que independentemente de onde emane essa classificação ela é capaz de construir um problema social. Entretanto, caso isso aconteça no âmbito penal, a criminalização não apenas cria o problema como também vai tentar combatê-lo por meios ineficazes. Em crítica ao agir penal menciona Tavares que

essa forma de racionalizar o processo de condenação, que se expressa na sentença, é também o reconhecimento de um perfil psicológico da norma, que não está dirigida à proteção do sujeito, mas tomada, unicamente, como instrumento mais eficaz de manifestação do poder punitivo [...].

386 MELOSSI, Dario; PAVARINI, Massimo. Cárcere e fábrica: as origens do sistema penitenciário. Tradução de Sérgio Lamarão. Rio de Janeiro: Revan, 2006.

387 URIARTE, Carlos Elías. Control institucional de la niñez adolescencia en infracción: un programa mínimo de contención y límites jurídicos al Sistema Penal Juvenil (las penas de lós jóvenes). Montevidéu: Carlos Alvarez, 1999. P. 23. 
Mas se esse sentimento não pode ser superado por meio da repressão, mas apenas pelo processo de compreensão ou, inclusive, pela tolerância, será muito difícil legitimar psicologicamente a pena; a racionalidade dessa concepção psicológica só poderá caminhar no sentido de deslegitimação de qualquer sanção penal [...]. Nesses termos seria ela irracional, como seria irracional o Direito Penal que a incorpora como seu elemento essencial. ${ }^{388}$

\section{Em outros termos, os}

arranjos do controle do crime envolvem, contudo, certos custos sociais que são, a longo prazo, menos facilmente acomodáveis. A intensificação das divisões sociais e raciais; o reforço de processos criminógenos; a alienação de muitos grupos sociais; o descrédito da autoridade legal; a redução da tolerância civil; a tendência ao autoritarismo - estes são resultados suscetíveis de serem produzidos pela confiança em mecanismos penais e na manutenção da ordem. ${ }^{389}$

Fato é que "a construção punitiva é uma forma de fragmentar violências possíveis, que deixa fora situações de violência estrutural, nas que não é possível perceber violências ou autores, em sentido convencional”. 390

De acordo com Baratta,

em um nível mais alto de abstração, o sistema punitivo se apresenta como um subsistema funcional da produção material e ideológica (legitimação) do sistema social global, é dizer, das relações de poder e de propriedade existentes, mais que como instrumento de tutela de interesses e direitos particulares dos indivíduos. ${ }^{391}$

388 TAVARES, Juarez. A racionalidade, o direito penal e o poder de punir: os limites da intervenção penal no Estado Democrático. In: ZILIO, Jacson; BOZZA, Fábio. Estudos críticos sobre o sistema penal: homenagem ao professor Doutor Juarez Cirino dos Santos por seu 70. ${ }^{\circ}$ aniversário. Curitiba: LedZe, 2012. p. 872-873.

389 GARLAND, David. A cultura do controle: crime e ordem social na sociedade contemporânea. Tradução de André Nascimento. Rio de Janeiro: Revan, 2008. p. 429.

390 URIARTE, Carlos Elías. Control institucional de la niñez adolescencia en infracción: un programa mínimo de contención y límites jurídicos al Sistema Penal Juvenil (las penas de lós jóvenes). Montevidéu: Carlos Alvarez, 1999. p. 19.

391 BARATTA, Alessandro. Principios del Derecho Penal Mínimo: para una teoría de los Derechos Humanos como objeto y límite de la ley penal. Doctrina Penal: Teoria y Práctica en las Ciencias Penales, Buenos Aires, v. 10, n. 37-40, p. 623-650, 1987. p. 625. 
A despeito das mencionadas falhas, referentes a sua ineficácia, também sua atuação é problemática, uma vez que o sistema penal é iminentemente seletivo, seletividade esta que macula qualquer pretensão de igualdade que se tentar defender a seu respeito.

Com o propósito de combater a criminalidade em toda a sociedade, o Direito Penal elege apenas alguns sujeitos, os mais socialmente vulneráveis, sobre os quais recai sua força, deixando os demais propositadamente à margem de seu alcance.

Reforçando essa ideia, assevera Zaffaroni que

na grande maioria dos casos os que são chamados de "delinquentes" pertencem aos setores sociais de menores recursos. Em geral, é bastante óbvio que quase todas as prisões do mundo estão povoadas por pobres. Isto indica que há um processo de seleção das pessoas às quais se qualifica como “delinquentes” e não, como se pretende, um mero processo de seleção de condutas ou ações qualificadas como tais. ${ }^{392}$

Ocorre que, mesmo com todas - e não são poucas - as suas vicissitudes, é o sistema penal que cada vez mais vem ganhando preponderância na realização do controle social. É ele que vem sendo chamado a agir diante da menor perturbação da ordem que surja.

Nesse diapasão,

a marginalização, a exclusão, a pobreza generalizada, as guerras civis, os massacres, a fome e a consequente morte de milhões de seres humanos são apresentados como condições necessárias à reengenharia social, onde as políticas compensatórias e o controle social repressivo se complementam. Ao "Estado mínimo" na esfera social e econômica corresponde o "Estado máximo" na esfera das políticas de segurança pública e no exercício do controle social através da "criminalização" dos problemas sociais. ${ }^{393}$

392 ZAFFARONI, Eugenio Raúl; PIERANGELI, José Henrique. Manual de direito penal brasileiro: parte geral. 8. ed. São Paulo: Revista dos Tribunais, 2010. p. 56.

393 DORNELLES, João Ricardo. Ofensiva neoliberal, globalização da violência e controle social. Discursos Sediciosos: crime, direito e sociedade, São Paulo, v. 7, n. 12, p. 119-137, 2002. p. 121. 
Por tudo isso, indaga Garland:

por que os governos adotam, tão rapidamente, soluções penais para lidar com o comportamento de populações marginalizadas, em vez de cuidarem das fontes sociais e econômicas de sua marginalização? Porque soluções penais são imediatas, fáceis de serem implementadas e podem alegar que "funcionam" como instrumento punitivo ainda que fracassem em todos os outros objetivos [...] Sobretudo, porque elas concentram o controle e a condenação nos grupos excluídos, deixando relativamente livre de regulação e censura o funcionamento dos mercados, das empresas e das classes sociais mais desfavorecidas. ${ }^{394}$

Assim, ao analisar as transformações na cultura do controle do crime na pósmodernidade, Garland identifica três aspectos principais.

Em primeiro lugar, ressalta a emergência de um previdenciarismo penal recodificado, donde emana uma preocupação cada vez maior com a segurança pública e cada vez menor com o réu. Assim, quer-se prender mais e com menos custo, afastar o indivíduo da sociedade, sem preocupar-se com seu bem-estar, bem como estigmatizá-lo deliberadamente, em virtude das facilidades de identificação que o estigma produz.

Em relação a este último aspecto revela o autor que

no enquadramento penal-previdenciário, a estigmatização era vista como efeito pernóstico e desnecessário da justiça criminal. Estigmatizar o criminoso era contraproducente na medida em que reduzia as possibilidades de ressocialização. [...]. Hoje em dia, o estigma tornou-se útil de novo. Duplamente útil, na verdade, uma vez que serve simultaneamente para punir o criminoso e alertar a comunidade para o perigo que ele representa. Práticas de notificação comunitária, registro de pedófilos, utilização de uniformes, acorrentamento coletivo de presos (nos estados norte-americanos do sul) e penas à moda "letra escarlate", que obrigam os criminosos a proclamarem sua culpa com placas e sinais - todos estes envolvem a estigmatização pública do criminoso. ${ }^{395}$

394 GARLAND, David. A cultura do controle: crime e ordem social na sociedade contemporânea. Tradução de André Nascimento. Rio de Janeiro: Revan, 2008. p. 423.

395 Idem, ibidem, p. 385. 
Em segundo lugar, o surgimento de duas facetas de uma Criminologia de controle.

As novas Criminologias da vida cotidiana, de tendência pós-moderna, preocupam-se com a organização do ambiente social de modo que possibilite menos conflitos. Note-se, porém, o perigo inerente a essa proposta, uma vez que a busca pela almejada organização social, se levada ao extremo, pode culminar na adoção de uma política de tolerância zero e na exclusão de determinados contingentes populacionais que atrapalhem esse objetivo.

A Criminologia do outro perigoso, por sua vez, de vertente antimoderna, defende, a todo custo, a manutenção e preservação da ordem e da autoridade.

Ao cotejar ambas, Garland analisa que

uma diz que "o crime é normal, acostume-se a ele”. "Seja realista, adaptese, proteja-se, sobreviva”. A outra vê a disseminação do crime como uma catástrofe pela qual alguém deve ser culpado, uma praga que atinge uma sociedade degenerada, preceituando o retorno a um modo de vida mais tradicional, talvez até temente a Deus. ${ }^{396}$

Por fim, a terceira tendência identificada pelo autor refere-se à adoção de um estilo econômico de pensamento, que propugna a expansão do controle a todas as áreas da vida social.

Em suas próprias palavras, trata-se de

controles do espaço, controles situacionais, controles gerenciais, controles do sistema, controles sociais, autocontroles - em um setor social depois do outro, deparamo-nos com a imposição de mais regimes intensivos de regulação, inspeção e controle; no processo, nossa cultura cívica se torna cada vez menos tolerante e inclusiva, cada vez menos capaz de confiar. ${ }^{397}$

396 GARLAND, David. A cultura do controle: crime e ordem social na sociedade contemporânea. Tradução de André Nascimento. Rio de Janeiro: Revan, 2008. p. 392-393.

397 Idem, ibidem, p. 415-416. 
Referindo-se à realidade brasileira, analisa Santos que, contemporaneamente, o controle social formal parece seguir três direções: expande-se, visando abarcar o maior número de pessoas; utiliza-se de técnicas industriais para processar o maior número de pessoas ao mesmo tempo; e bifurca-se a depender do sujeito contemplado, sendo ele mais leve para autores de crimes menos graves e mais rigoroso para os autores dos crimes mais reprováveis. ${ }^{398}$

Ante o exposto, estudados os pressupostos teóricos do controle social formal, necessário se faz a análise deste, outra faceta do sistema de vigília de comportamentos.

\subsubsection{Controle social informal}

O controle social informal se entabula nos aspectos relacionais da vida cotidiana, nos contatos que o indivíduo estabelece no dia a dia com os seus pares, no bojo das relações e instituições que conformam a sociedade civil. Assim, "independentemente das especificidades da trajetória particular de cada um, é possível afirmar que qualquer interação entre dois ou mais seres humanos, enseja algum grau de controle entre os participantes dessa experiência relacional”. 399

Nesse diapasão, o controle social informal dos comportamentos é realizado pelas instituições da sociedade civil como a família, a escola, os habitantes do bairro e a mídia, no intuito de zelar pela observância das normas sociais, ainda que mediante sanções, sendo feito por qualquer pessoa, sem que essa tarefa corresponda a uma exigência de sua atividade profissional. Ademais, todas essas agências realizam, de alguma maneira, a educação dos controlados, razão pela qual, com exceção da escola, são consideradas agências informais de educação.

Sua atuação pode compreender um rol bastante diverso de condutas e assumir distintos graus de intensidade, os quais variam de acordo com a distância existente entre as

398 SANTOS, Juarez Cirino. A criminologia radical. Rio de janeiro: Forense, 1981.

399 CARDOSO, Franciele Silva. A luta e a lida: estudo do controle social do MST nos acampamentos e assentamentos de reforma agrária. São Paulo: IBCCrim, 2012. p. 125-126. 
partes envolvidas, a sujeição ou não do agente ao controle, o reforço da audiência circundante e a percepção sobre a eficácia e suficiência da intervenção. ${ }^{400}$

Esse modo de verificação caracteriza-se ainda pela inespecificidade de competências para as ações de controle e pelo caráter mais brando das etiquetas que aplica. ${ }^{401}$ Ademais, utiliza-se de meios mais difusos ou encobertos em cotejo com o controle social formal.

Assim,

expressa-se por meio do ridículo, da zombaria, dos comentários malévolos, da reprovação, dos castigos morais e até de castigos físicos [...] (quando tais castigos são impostos pelo costume e pela tradição, como é o caso das surras aplicadas pelos pais) [...]. Prêmios, recompensas, elogios, honrarias são também recursos informais utilizados pelos grupos primários. ${ }^{402}$

Importante destacar que o controle social informal é deveras sistematizado, uma vez que "a interação dos órgãos do controle é quase perfeita. São quase inexistentes as contradições entre o que transmite essa unidade essencialíssima da educação que é a família, ou a Igreja, ou a televisão, ou a literatura infantil”. 403

Note-se que a ausência do Estado, em seu aparato repressivo é característica marcante do controle social informal.

Esse modo de modulação de ações é considerado mais efetivo, menos custoso, porquanto ele não causa nenhuma ou, pelo menos, causa consequências menos negativas que a ação do controle formal.

400 CARDOSO, Franciele Silva. A luta e a lida: estudo do controle social do MST nos acampamentos e assentamentos de reforma agrária. São Paulo: IBCCrim, 2012. p. 55-67.

401 GABALDÓN, Luis Gerardo. Polícia, transgressión juvenil y control social informal. In: SERRANO MAÍlLO, Alfonso; GUZMÁN DÁLBORA, José Luis (Eds.). Procesos de infracción de normas y de reacción de normas: dos tradiciones criminológicas. Madrid: Dykinson, 2008. p. 55-67.

402 COSTA, Álvaro Mayrink da. Raízes da sociedade criminógena. Rio de Janeiro: Lumen Juris, 1997. p. 280.

403 CASTRO, Lola Aniyar de. Criminologia da libertação. Tradução de Sylvia Moretzsohn. Rio de Janeiro: Revan, 2005. p. 155. 
Entretanto, pode-se questionar se tais afirmações representam a realidade do exercício do controle social informal ou o desconhecimento advindo da falta de estudos criminológicos específicos acerca das relações que o compõem.

Nesse diapasão, assevera Barreiras que

em muitos textos o que se encontra é uma breve referência ao controle informal como instância extremamente eficiente e poderosa na prevenção da criminalidade, sem maiores explicações sobre cada uma das instituições portadoras desse tipo de controle, e sem dados científicos que comprovem a alegada eficiência.

Tal fato pode ser visto como consequência da dificuldade que enfrentaria um criminólogo ao pretender estudar, por exemplo, a família, a escola ou as relações de vizinhança. Seria sempre necessário um estudo bastante mais afeito com outras ciências humanas, como a antropologia, a sociologia ou mesmo a história, o que pode causar razoável desconforto ao profissional que se dedica a estudar o fenômeno do crime. ${ }^{404}$

Sem dúvida que a fiscalização de comportamentos exercida pelo controle social informal, em razão de sua sutileza, reveste-se de uma aparência de naturalidade e espontaneidade, como se ele fosse inerente a qualquer organização social saudável. Contudo, a uniformização dos comportamentos é sempre artificial, resultado de processos de adequações, contenções e renúncias. ${ }^{405}$

Ele até pode ser menos perceptível, mas não por isso menos controlador, uma vez que se baseia na ideia de autoridade, na possibilidade que uns têm de determinar as ações alheias. Em outros termos, “é possível afirmar que a justificativa última de toda forma de controle - mesmo o informal - é alguma forma de autoridade, que tanto pode ser fundamentada em aspectos morais, educacionais, religiosos ou simplesmente temor reverencial”. 406

404 BARREIRAS, Mariana Barros. Controle social informal x controle social formal. In: SÁ, Alvino Augusto de; SHECAIRA, Sérgio Salomão. Criminologia e os problemas da atualidade. São Paulo: Atlas, 2008. p. 300.

405 CARDOSO, Franciele Silva. A luta e a lida: estudo do controle social do MST nos acampamentos e assentamentos de reforma agrária. São Paulo: IBCCrim, 2012.

406 Idem, ibidem, p. 139. 
Trata-se, então, de "uma intensa e multifacética maneira de educar os indivíduos”, 407 a qual pode ser realizada isoladamente, como estratégia única de vigília das ações ou em dualidade com o controle social formal, outro extremo do poder de controle.

Assim, conforme assevera Andrade, “o sistema penal não realiza o processo de criminalização e estigmatização à margem ou inclusive contra os processos gerais de etiquetamento que têm lugar no seio do controle social informal como a família e a escola”. 408

Ademais, acompanha a expansão do controle social formal apontada no excerto anterior o crescimento do controle social informal. Nesse diapasão, assevera Wacqüant que

da área penal e policial, a noção de "tolerância zero" difundiu-se, segundo um processo de metástase, designando, alternada e desordenadamente, a aplicação estrita da disciplina parental no seio das famílias, a expulsão automática dos colegas que portam uma arma nas escolas, a suspensão dos desportistas profissionais culpados de violência fora dos estádios, o controle minucioso do contrabando de drogas nas prisões, mas também a recusa absoluta dos estereótipos raciais, a sanção severa aos comportamentos grosseiros dos passageiros de avião e a intransigência tanto em relação aos detritos nos parques e jardins públicos quanto às crianças sem cintos de segurança nos bancos traseiros dos automóveis e ao estacionamento em fila dupla ao longo das ruas de comércio. $^{409}$

Evidente, então, que “a incômoda situação da avaliação comportamental constante não está restrita aos ambientes 'formalmente institucionalizados”, 410 sendo certo, inclusive, que instituições aparentemente inofensivas exercem a função importante de vigilância e contenção dos sujeitos.

Nesse sentido que se manifesta Cardoso ao defender que no âmbito doméstico

407 CASTRO, Lola Aniyar de. Criminologia da libertação. Tradução de Sylvia Moretzsohn. Rio de Janeiro: Revan, 2005. p. 153.

408 ANDRADE, Vera Regina Pereira de. A ilusão da segurança jurídica: do controle da violência à violência do controle penal. 2. ed. Porto Alegre: Livraria do Advogado, 2003. p. 210.

409 WACQUANT, Loïc. A globalização da tolerância zero. Discursos Sediciosos, Rio de Janeiro, v. 5, n. 9/10, p. 111-119, 2000. p. 116.

410 CARDOSO, Franciele Silva. A luta e a lida: estudo do controle social do MST nos acampamentos e assentamentos de reforma agrária. São Paulo: IBCCrim, 2012. p. 128. 
mesmo e apesar do afeto, o aprendizado da criança perpassa por uma postura vigilante, por repreensões e censuras, ou seja, por julgamentos constantes por parte dos adultos responsáveis pela manutenção da coesão familiar. Ou seja, mesmo em casa somos julgados o tempo todo, algo que, num primeiro momento, seria mais esperado dos órgãos de controle social formal. ${ }^{411}$

Fato é que em virtude da sua dependência financeira e por estarem sujeitos a autoridade dos adultos, o controle social informal exerce-se mais fortemente sobre as crianças e os jovens. ${ }^{412}$

Entre as agências encarregadas do exercício do controle social informal, hodiernamente é a mídia que tem ganhado bastante destaque no exercício desse poder de guiar e fiscalizar as condutas de seus espectadores.

Outrora, era muito comum que os vizinhos se conhecessem e frequentassem a casa uns dos outros, que os membros de dada comunidade se encontrassem na missa de domingo ou participassem da associação do bairro. Atualmente, mormente nas grandes cidades onde os encontros e as conversas com o outro são cada vez mais raros, esses modos de exercício de controle vêm perdendo lugar para o único instrumento que efetivamente chega ao lar da maioria dos cidadãos que é a informação veiculada pelos meios de comunicação.

Sua principal atividade tem sido a difusão do pânico social. Ao trabalhar com o sensacional, ela privilegia a transmissão de acontecimentos chocantes, capazes de causar profunda comoção popular, deixando de lado os acontecimentos corriqueiros de violência, mais reais e muito menos danosos que os apresentados.

Conforme análise de Michaud, a mídia introduz novos elementos na relação que as pessoas têm com a violência. ${ }^{413}$

411 CARDOSO, Franciele Silva. A luta e a lida: estudo do controle social do MST nos acampamentos e assentamentos de reforma agrária. São Paulo: IBCCrim, 2012. p. 127.

412 GABALDÓN, Luis Geraldo. Policía, transgressión juvenile y control social informal. In: MAÍLLO, Alfonso Serrano; DÁLBORA, José Luis Gúzmán (Eds.). Procesos de infracción de normas y de reacción a la infracción de normas: dos tradiciones criminológicas. Madrid: Dykinson, 2008. p. 55-67. 
Para ele, as relações dos indivíduos com os acontecimentos passa por sua experiência direta, bem como pelos testemunhos e evidências indiretos que têm sobre eles. As informações veiculadas pelos meios de comunicação multiplicam as evidências indiretas da violência, criando a sensação de que vivemos o terror, de que efetivamente participamos daquilo que foi experienciado pela televisão.

Todavia, assegura o autor que as imagens das violências veiculadas na mídia são enganosas. Ainda que elas sejam verdadeiras, elas podem ser editadas, legendadas e selecionadas. Em outros termos, elas podem ser distorcidas. Assim, o que assusta não são as violências efetivas, e sim as imagens que fazemos delas, o que dela ficamos sabendo e imaginando.

A maioria das pessoas, então, não tem medo por já terem sido vítimas diretas de um ato de violência, e sim porque ouviram falar sobre algum caso que aconteceu em algum lugar do mundo ou do país.

Diante disso, fica claro que uma das consequências mais importantes da ação da mídia é contribuir para tornar a violência irreal, uma vez que as imagens não representam a realidade. É nesse sentido que o autor as denomina violência com celofane, ou seja, a violência envolta em uma máscara que oculta a realidade dos fatos.

Logo, "se é verdade que a experiência contemporânea da violência passa em grande parte pelas imagens, tal experiência só pode ser suavizada e banalizada. É nesse sentido que as imagens da violência são perigosas”. 414

A despeito da multiplicidade das agências de controle social informal existentes, mister para o presente estudo entender, especificamente, como a escola executa tal tarefa. É isso o que se começará a fazer a partir de agora.

413 MICHAUD, Yves. A violência. Tradução de L. Garcia. São Paulo: Ática, 1989.

414 Idem, ibidem, p. 51. 


\subsection{A escola como instrumento do controle social informal: um diálogo entre a Educação e a Criminologia}

No que se refere especificamente ao processo de socialização e de controle de crianças e adolescentes, pode-se afirmar que “a moderna condição juvenil na sociedade ocidental sempre foi caracterizada pela manutenção de relações importantes, embora diversas, entre duas agências primordiais da reprodução social: a família e a escola”. ${ }^{415}$

Apesar de a família ser o primeiro ambiente de socialização e de controle social com que a criança tem contato, contemporaneamente ela vem perdendo seu espaço para a escola.

Fato é que

a escola é a primeira instituição à que se incorporam as crianças, descontando a família, a que ocupa o período que medeia entre a exclusividade desta e o trabalho e, de qualquer forma, a escolarização representa seu primeiro contato com uma instituição formal e/ou burocrática, com uma organização. Por conseguinte, é nela onde crianças e jovens fazem a primeira experiência do trato regular com estranhos, do trato com outras pessoas fora dos laços de parentesco ou da comunidade imediata. $^{416}$

Tendo as mulheres alcançado a possibilidade de acessar os postos de trabalho, tal qual sempre ocorreu com os homens, torna-se necessário que as famílias deixem seus filhos sob os cuidados de alguém ou de alguma instituição capaz de executar a contento tal tarefa.

Aliada a essa situação, pelo menos no caso brasileiro, a democratização do acesso escolar iniciada na década de 1990 também colaborou para o aumento da frequência

415 SPOSITO, Marília Pontes. Algumas reflexões e muitas indagações sobre as relações entre juventude e escola no Brasil. In: ABRAMO, Helena Wendel; BRANCO, Pedro Paulo Martoni (Orgs). Retratos da juventude brasileira: análises de uma pesquisa nacional. São Paulo: Perseu Abramo, 2005. p. 89.

416 ENGUITA, Mariano Fernández. A face oculta da escola: educação e trabalho no capitalismo. Tradução de Tomaz Tadeu da Silva. Porto Alegre: Artes Médicas, 1989. p. 158. 
dos jovens à escola, sendo que se estima que hoje um a cada três brasileiros frequentem a instituição, índice semelhante ao de países como França e Reino Unido. ${ }^{417}$

Diante disso, do ponto de visa qualitativo, é provável que as escolas estejam incorporando elementos antes excluídos, com origem familiar e social, diversos daqueles que tipicamente a frequentavam, ${ }^{418}$ sendo mister que se oriente de acordo com essa nova conjectura, sob pena de converter diferenças culturais em desigualdades pejorativas.

Ademais, afora o grande número de crianças e adolescentes que frequentam a escola, há de se ressaltar o tempo que despendem no estabelecimento. Eles permanecem nas instituições de ensino cinco dias por semana, trinta ou mais semanas por ano, por longos anos de sua vida, sendo ainda que além das horas efetivamente experimentadas na escola, as atividades escolares penetram também seu tempo livre, quando, por exemplo, realizam tarefas extraescolares. ${ }^{419}$

Por tudo isso que a própria sociedade reserva à escola papel fundamental. A comunidade

atribui-lhe uma importância que chega à identificação entre a condição de criança ou jovem e a de escolar. A primeira coisa que perguntamos a uma criança, depois de seu nome, é o que está estudando ou como vão os estudos. Para as próprias crianças e para os jovens é difícil não adotar como imagem própria, ou como parte da mesma, a que lhes devolve a escola. A escola apresenta-se perante eles, ou assim o proclama a sociedade, como a única coisa séria que existe nesse período da sua vida: o resto é o brinquedo, o privado, o trivial. ${ }^{420}$

Assim, dada a importância da instituição, mister que se aprofunde a compreensão acerca de seu funcionamento.

\footnotetext{
417 KAHN, Túlio. Efeitos das mudanças no sistema escolar sobre a violência. Revista do ILANUD, São Paulo, n. 23, 79-105, 2002.

418 Idem, ibidem, 2002.

419 ENGUITA, Mariano Fernández. A face oculta da escola: educação e trabalho no capitalismo. Tradução de Tomaz Tadeu da Silva. Porto Alegre: Artes Médicas, 1989.

420 Idem, ibidem, p. 157.
} 
É possível distinguir na história recente da sociologia da educação dois momentos diversos. O primeiro, que vai até a década de 1960 em que a educação é concebida como fator de democratização, momento em que existia um otimismo em relação a sua função. O segundo, a partir de 1970, baseado em um pessimismo pedagógico, em que "não tendo a educação satisfeito as elevadas expectativas em relação aos seus efeitos sociais e econômicos, seguiu-se um período de desilusão e cinismo, quando a educação passa a ser vista predominantemente como um processo de manutenção do poder estabelecido". ${ }^{421}$

Em realidade, essa descrença na conjuntura social dominou o período, afetando não apenas a área da Educação, mas também outros ramos da ciência.

Fato é que, nesse momento, toda a tessitura social passou a ser vista dentro de uma perspectiva crítica e conflitiva. Na Criminologia, desvelaram-se as relações de poder e dominação que derivam da organização social, denunciando as estratégias do sistema no controle dos vulneráveis. Na Educação, destacou-se a sua função de instrumento dissimulado de dominação e de reprodução da estrutura classista da sociedade. ${ }^{422}$

É exatamente nesse ponto em que ambas as ciências encontram-se neste trabalho, justamente quando se passa a perquirir não apenas as virtudes, mas também os problemas da educação escolar.

A junção de ambos os conhecimentos na análise que se realiza é necessária, até porque

a maior parte da historiografia da escola, elaborada geralmente por escolares já crescidos mas que raramente saíram dos claustros da instituição, tendeu a basear-se na mera análise da evolução do discurso pedagógico, da sucessão de escolas modelares através das épocas ou da evolução das cifras agregadas que agrupavam sob epígrafes comuns realidades não acumuláveis nem comparáveis. [...] sempre é mais conveniente apresentar a história da escola como um longo e frutífero caminho desde as presumidas misérias de ontem até as supostas glórias

\footnotetext{
${ }^{421}$ GOMES, Candido Alberto. A educação em novas perspectivas sociológicas. 4. ed. São Paulo: EPU, 2005. p. 1.

422 Idem, ibidem.
} 
de hoje ou de amanhã que, por exemplo, como um processo de domesticação da humanidade a serviço dos poderosos. ${ }^{423}$

Assim, para Castro, uma Criminologia da libertação, afinada com a realidade contemporânea e com a situação específica da América Latina, deve realizar a tarefa de resgatar a transparência do discurso do controle social informal, ${ }^{424}$ de desvendar o controle social informal realizado pela escola, atividade que demonstra a importância de a Criminologia ocupar-se do estudo da instituição.

Para tal desiderato, mister que se parta do pressuposto teórico proposto pela Criminologia crítica, uma vez que "a Criminologia tradicional construiu, por sua vez, uma educação de relevo. Os criminólogos foram professores de segunda mão; como tais, guardiões da ordem, costureiros que remendam o fracasso da escola”. 425

Logo, basear o estudo da instituição nos referenciais da Criminologia tradicional significa aceitar a escola como mero elemento integrador do consenso social, como instituição acrítica e apolítica, esquecendo-se que ela integra a estrutura de poder do Estado.

Nesse contexto, fundamental desvincular-se do idealismo que muitas vezes marcou o pensamento educacional e desvelar sua face oculta.

Em seu momento inicial, as escolas surgem para atender aos meninos provenientes da pequena e média burguesia, sendo excluído o seu acesso aos campesinos, aos artesãos, às mulheres ${ }^{426}$ e às minorias étnicas.

${ }^{423}$ ENGUITA, Mariano Fernández. A face oculta da escola: educação e trabalho no capitalismo. Tradução de Tomaz Tadeu da Silva. Porto Alegre: Artes Médicas, 1989. p. 131.

424 CASTRO, Lola Aniyar de. Criminologia da libertação. Tradução de Sylvia Moretzsohn. Rio de Janeiro: Revan, 2005.

425 Idem, ibidem, p. 165.

426 Importante asseverar que a exclusão das mulheres era devida à crença de que elas podiam ser educadas por suas próprias mães ou por "escolas" cuja tarefa não era a de ensinar-lhes a ler e escrever, e sim incutir-lhe disciplina, piedade e bons costumes, qualidades essenciais a uma boa esposa e mãe de família. 
Em um segundo momento de sua evolução histórica, as instituições de ensino incorporaram ao seu corpo discente as mulheres e as minorias étnicas, ainda de maneira segregada.

Sobre esse período assevera Enguita que os burgueses, ao ascenderem ao poder, passaram a defender o ideal de educação para o povo, intencionando com isso a garantia de sua mantença, bem como a aceitação da nova conjuntura social. Ocorre que, ao mesmo tempo, eles temiam as consequências de educar demasiadamente os cidadãos do povo, os quais deveriam conformar-se com sua situação social desprivilegiada e não almejar ascender socialmente. Diante disso, a solução encontrada foi a de "educá-los, mas não demasiadamente. $\mathrm{O}$ bastante para que aprendessem a respeitar a ordem social, mas não tanto que pudessem questioná-la”. 427

Apenas mais tarde, em um terceiro momento, que todos os grupos sociais foram ou estão sendo integrados à escola. ${ }^{428}$

Assim, em um contexto em que cada vez mais crianças e adolescentes com histórias e origens de vida diversas acessam as instituições de ensino e passam aí a maior parte de seu tempo, não é de estranhar que elas exerçam papel fundamental entre eles.

A despeito de sua função ${ }^{429}$ precípua e declarada de transmissora de conhecimentos, de educação, a escola é uma instituição de controle social, que conta com uma história própria e com conflitos particulares. Nela há uma gama de atores que se interrelacionam em um complexo emaranhado de relações sociais simétricas e assimétricas, nas quais estão em jogo elementos de poder e de autoridade.

427 ENGUITA, Mariano Fernández. A face oculta da escola: educação e trabalho no capitalismo. Tradução de Tomaz Tadeu da Silva. Porto Alegre: Artes Médicas, 1989. p. 112.

428 CHALUH, Laura Noemi. Educação e diversidade: um projeto pedagógico na escola. Campinas: Alínea, 2006.

429 Lenhard explica que o termo função expressa a relação entre uma dada instituição, nesse caso a escolar, e as necessidades sociais, uma vez que se refere ao papel que uma atividade representa na vida social e a contribuição que presta na manutenção da continuidade estrutural. Cf. LENHARD, Rudolf. Sociologia educacional. São Paulo: Livraria Pioneira, 1973. 
Logo, evidencia-se que "a escola tem uma ação bem mais complexa e diversificada com efeitos não esperados por muitos atores”. ${ }^{430}$ Nesse sentido,

apenas uma pequena parte do tempo dos professores e alunos nas escolas é dedicada à transmissão ou aquisição de conhecimentos. O resto, a maior parte, é empregado em forçar ou evitar rotinas, em impor ou escapar ao controle, em manter ou romper a ordem. ${ }^{431}$

Contudo, conforme se mencionou no item anterior, a aceitação acrítica das instâncias sociais de controle informal tem impedido o questionamento destas no exercício das tarefas que efetivamente realizam. Essa realidade mostra-se ainda mais evidente na escola, cuja função de tradição dos conhecimentos comumente é a única reconhecida.

\section{Conforme alerta Enquita,}

se o objetivo da educação fosse somente comunicativo - extrair, transmitir ou inculcar informações, conhecimentos, ideias, etc. - a escola estaria na iminência de ser varrida da face da terra, ou já o teria sido, pelos meios de comunicação de massas, que são incomparavelmente mais eficazes no que respeita a esse fim, mais atrativos e baratos. ${ }^{432}$

Mister, pois, perquirir como e sobre que bases a escola realiza a função de controle social de seus alunos, identificando se ela serve para reproduzir as desigualdades sociais e as relações de trabalho capitalistas ou se é elemento de democratização, de fomento da igualdade entre os que a frequentam.

Nesse sentido, vale alertar, desde já, que “as relações entre a escola, o Estado e o sistema econômico não são simples, unidirecionais ou deterministas, mas, sim, complexas, multidirecionais, contraditórias e permanentemente em tensão de mudança” ${ }^{433}$

430 GOMES, Candido Alberto. A educação em novas perspectivas sociológicas. 4. ed. São Paulo: EPU, 2005. p. 72.

431 ENGUITA, Mariano Fernández. A face oculta da escola: educação e trabalho no capitalismo. Tradução de Tomaz Tadeu da Silva. Porto Alegre: Artes Médicas, 1989. p. 158.

432 Idem, ibidem, p. 158.

433 GOMES, Candido Alberto. A educação em novas perspectivas sociológicas. 4. ed. São Paulo: EPU, 2005. p. 74-75. 
Enquanto a escola, ao receber em seus domínios crianças e adolescentes provenientes de todos os estratos sociais, deveria ocupar-se de promover a igualdade, ela colabora sobremaneira para aprofundar as diferenças entre os grupos que agrega. Por conseguinte, defende Illich que embora a igualdade de oportunidades na educação seja uma meta desejável, "confundi-la com obrigação escolar é confundir salvação com igreja”. 434

Conforme elucidado no Capítulo 1 deste trabalho, em realidade, por mais que, ao menos em tese, todos possam alcançar a escola, há uma educação a qual apenas o rico tem acesso e outra para o pobre: a escola frequentada por ambos não é a mesma e não têm a mesma qualidade.

Há, portanto, diferentes educações para diferentes públicos.

Fato é que "as escolas, por sua própria estrutura, opõem-se à concentração de privilégios naqueles que estão, de outra forma, em desvantagem. Currículos especiais, classes separadas ou aulas mais longas constituem mais discriminação, a um custo mais elevado". 435

Essa discriminação vai refletir-se, no futuro, na colocação profissional dos jovens. Os que estudaram nos melhores colégios é que acessarão também os melhores empregos, enquanto os demais assumirão os trabalhos excedentes e mais mal remunerados.

Nesse diapasão Enguita defende que a criança ao ser enviada a escola, desde seu princípio histórico, o foi para aprender e adaptar-se às relações de produção: cada estudante é preparado, é moldado, pois, para assumir no mercado de trabalho um cargo condizente com sua classe social. Assim,

através da imersão sistemática em algumas relações sociais educacionais isomorfas com as relações sociais de produção dominantes, a escola seleciona nos indivíduos que constituem seu público aqueles traços que mais convêm a estas e, se não existem previamente de forma potencial,

434 ILLICH, Ivan. Sociedade sem escolas. 4. ed. Tradução de Lúcia Mathilde Endlich Orth. Petrópolis: Vozes, 1973. p. 85.

435 Idem, ibidem, p. 28. 
utiliza todos os recursos a seu alcance para gerá-los. De certo modo, estes traços de personalidade podem ser considerados como o resultado da interação entre o indivíduo e seu ambiente, isto é, como produto da interiorização das relações sociais. ${ }^{436}$

É no mesmo sentido a análise de Castro sobre o sistema escolar. Para ela,

os ricos continuarão sendo os condutores, graças à meritocracia criada por nosso sistema escolar. Os pobres, por insuficiência pessoal ou por carência de recursos, continuarão sendo operários, artesãos ou desempregados. Perpetuam-se, assim, os estratos dominados. ${ }^{437}$

E em sociedades capitalistas marcadas pela desigualdade social "maior será a relação entre saber e poder porque, embora as condições para o saber sejam, como em qualquer sociedade, produzidas coletivamente, o conhecimento em si acaba ficando nas mãos de alguns". 438

Portanto, uma atitude que pode colaborar na compreensão da realidade das escolas é aceitar que seu sistema não foi estruturado para atender às diversidades de grupos sociais ${ }^{439}$ que ela foi criada para reproduzir as relações sociais desiguais.

Diante disso,

para além do problema de se identificar o real efeito das experiências de socialização secundária para explicar as condutas humanas, o certo é que a própria prática pedagógica está em disputa. Sem olvidar de que é um poderoso instrumento ideológico, de formação e por isso de controle social, o processo educacional comporta as mais diversas posições teóricas e, entre estas, há aquelas que sustentam exatamente aquilo que os criminólogos críticos apontam como o mais acertado para se alcançar a emancipação social dos oprimidos a partir da tomada de consciência

436 ENGUITA, Mariano Fernández. A face oculta da escola: educação e trabalho no capitalismo. Tradução de Tomaz Tadeu da Silva. Porto Alegre: Artes Médicas, 1989. p. 187.

437 CASTRO, Lola Aniyar de. Criminologia da libertação. Tradução de Sylvia Moretzsohn. Rio de Janeiro: Revan, 2005. p. 161.

438 KRUPPA, Sonia M. Portella. Sociologia da educação. São Paulo: Cortez, 1994. p. 27.

439 ANDRADE, Eliane Ribeiro; NETO, Miguel Farah. Juventudes e trajetórias escolares: conquistando o direito à educação. In: ABRAMOVAY, Miriam; ANDRADE, Eliane Ribeiro; ESTEVES, Luis Carlos Gil. Juventudes: outros olhares sobre a diversidade. Brasília: Ministério da Educação, Secretaria da Ação Continuada, Alfabetização e Diversidade; Unesco, 2007. 
acerca da desigualdade social, da exploração, da criminalização, enfim, dos diversos e poderosos instrumentos de que dispõem os detentores do poder econômico para subjugar a esmagadora maioria da população. ${ }^{440}$

Importante perceber, que a escola, por tratar-se de uma microssociedade, reproduz, ao menos em partes, já que conta com certas peculiaridades inerentes a sua função social, a organização presente na sociedade como um todo. Assim, estão também presentes em seu bojo os controles sociais externos, que nesses ambientes, além de desempenharem a função de ordenar a vida escolar, têm também uma finalidade socializadora.

Identifica-se, pois, na escola, a existência de um controle organizado e de outro difuso, os quais podem ser referenciados pelas expressões controle social formal e informal, respectivamente.

Pelo primeiro, impõem-se aos alunos as sanções previstas nos regulamentos escolares, quando da infração de normas explicitamente disciplinadas, as quais são aplicadas pelo professor, diretor, inspetor de alunos e outros funcionários do estabelecimento. O segundo, por sua vez, menos definido e menos claro que o outro, refere-se a sistemas normativos próprios e a sanções consolidadas nos grupos que integram a escola. ${ }^{441}$

Também aqui, a informalidade do controle não o torna mais fraco, sendo as suas consequências ainda mais gravosas em cotejo com as emanadas do controle formal, uma vez que se referem elas ao estremecimento das relações que o estudante estabelece com seus pares.

Na realidade, “a criança e o jovem, desafiando-os, incorrem na reprovação dos seus pares, manifestada por rejeição de contatos, atribuição de posição inferior ou punições

440 CARDOSO, Franciele Silva. A luta e a lida: estudo do controle social do MST nos acampamentos e assentamentos de reforma agrária. São Paulo: IBCCrim, 2012. p. 133.

441 LENHARD, Rudolf. Sociologia educacional. São Paulo: Livraria Pioneira, 1973. 
corporais, cuja maior eficácia está em expressarem (quando é o caso), precisamente, a rejeição". 442

Referindo-se especificamente à realidade brasileira, evidencia-se que o poder da escola não é diverso do até aqui relatado. A história da educação nacional comprova como a escola pode e tem servido como elemento ideológico de controle social, uma vez que se sabe que “o controle sobre a educação nacional significa o acesso direto não só às mentes dos cidadãos como também aos seus corpos”. ${ }^{443}$

Destaca-se, desde já, que a escola brasileira historicamente tem refletido o modelo estatal presente na sociedade, sendo certo que os estudantes economicamente privilegiados têm sido tratados como cidadãos, enquanto na realidade da escola pública vivem-se situações explícitas de negação dessa cidadania. ${ }^{444}$

No período colonial, o exercício do controle social sobre as crianças permitia aos jesuítas utilizarem-se do castigo físico na correção e no disciplinamento dos infantes. Na segunda metade do século XVIII, nas chamadas Aulas Régias, estabeleceu-se o uso da palmatória como instrumento de correção dos estudantes e evidenciou-se a preocupação em adestrar as crianças para se tornarem adultos responsáveis. ${ }^{445}$

Após a proclamação da República, difundiu-se a ideia de que a família desestruturada era berço de criminosos, razão pela qual o Estado assumiu para si, mediante políticas sociais específicas destinadas aos pobres, a tarefa de educação, saúde e punição de crianças e adolescentes.

Nesse período a criança pobre era vista como potencialmente perigosa, sendo que

442 LENHARD, Rudolf. Sociologia educacional. São Paulo: Livraria Pioneira, 1973. p. 151.

443 CORRÊA, Guilherme. Um corpo para a tolerância. In: PASSETTI, Edson; OLIVEIRA, Salete (Orgs.). A intolerância e o intempestivo. Cotia: Ateliê Editorial, 2005. p. 177.

444 KRUPPA, Sonia M. Portella. Sociologia da educação. São Paulo: Cortez, 1994.

445 DEL PRIORE, Mary. O cotidiano da criança livre no Brasil entre a Colônia e o Império. In: DEL PRIORE, Mary (Org.). História das crianças no Brasil. São Paulo: Contexto, 2007. p. 84-106. 
pretendendo domesticar as individualidades e garantindo com isso os preceitos de uma prevenção geral, os governos passaram a investir em educação, sob o controle do Estado, para criar cidadãos a reivindicar disciplinadamente segundo as expectativas de uma direção política cada vez mais centralizadora. Para tal, escola e internato passam a ser fundamentais. ${ }^{446}$

Por sua vez, a partir do Estado Novo, com o aumento da intervenção estatal sobre a escola, percebeu-se que "a educação popular tem servido mais como instrumento de cooptação dos pobres à ideologia oficial do que como meio de ascensão, emancipação rumo ao prestígio social”. ${ }^{447}$

Inclusive, a Constituição de 1937, deixa clara a necessidade de uma educação para os pobres adequada às suas faculdades, aptidões e tendências vocacionais e de um ensino voltado ao mercado de trabalho, ao aprendizado profissional e não ao seu crescimento intelectual e sua emancipação. ${ }^{448}$

A ditadura também utilizou-se da educação como estratégia para controle dos cidadãos.

No ano de 1961, com a promulgação da primeira Lei de Diretrizes e Bases, todas as instituições de ensino passaram a ser fiscalizadas pelo Estado. A reforma educacional, todavia, alcançou o ápice de seu êxito dez anos mais tarde, quando pela

446 PASSETTI, Edson. Crianças carentes e políticas públicas. In: DEL PRIORE, Mary (Org.). História das crianças no Brasil. São Paulo: Contexto, 2007. p. 355.

447 BARREIRAS, Mariana Barros. Controle social informal $x$ controle social formal. In: SÁ, Alvino Augusto de; SHECAIRA, Sérgio Salomão. Criminologia e os problemas da atualidade. São Paulo: Atlas, 2008. p. 305.

448 “À infância e à juventude, a que faltarem os recursos necessários à educação em instituições particulares, é dever da Nação, dos Estados e dos Municípios assegurar, pela fundação de instituições públicas de ensino em todos os seus graus, a possibilidade de receber uma educação adequada às suas faculdades, aptidões e tendências vocacionais.

O ensino pré-vocacional profissional destinado às classes menos favorecidas é em matéria de educação o primeiro dever de Estado. Cumpre-lhe dar execução a esse dever, fundando institutos de ensino profissional e subsidiando os de iniciativa dos Estados, dos Municípios e dos indivíduos ou associações particulares e profissionais.

É dever das indústrias e dos sindicatos econômicos criar, na esfera da sua especialidade, escolas de aprendizes, destinadas aos filhos de seus operários ou de seus associados. A lei regulará o cumprimento desse dever e os poderes que caberão ao Estado, sobre essas escolas, bem como os auxílios, facilidades e subsídios a lhes serem concedidos pelo Poder Público” (Cf. BRASIL. Constituição (1937). Disponível em: <http://www.planalto.gov.br/ccivil_03/constituicao/constitui\%C3\%A7ao37.htm>. Acesso em: 3 jan. 2014). 
segunda Lei de Diretrizes e Bases criou-se uma rede de escolas públicas de alcance nacional.

Esse momento representou “a grande virada da educação no Brasil, definida pela ditadura militar e sua percepção da educação como estratégia de segurança nacional, conforme ditava a política dos Estados Unidos em plena guerra fria”. ${ }^{449}$

Nos últimos trinta anos, o que se tem evidenciado é a interferência da estrutura capitalista na escola, sendo suas marcas o autoritarismo e a centralização do poder. ${ }^{450}$

Se até aqui se afirmou que a escola realiza a tarefa de controle social de condutas, mister evidenciar como ela realiza essa atividade. Torna-se fundamental, pois, perquirir de que instrumentos ela se utiliza para cumprir tal desiderato.

\subsubsection{Obediência, ordem e disciplina: os mecanismos do controle}

A obediência, a ordem e a disciplina são as bases estruturais da escola, sendo as maneiras pelas quais ela exerce seu controle.

Relacionando esses três elementos, Castro assevera que produção de obediência e controle social são as mesmas coisas, enquanto a disciplina é a ginástica necessária para a obtenção da obediência. ${ }^{451}$ A ordem, por sua vez, integra esse esquema como a estrutura essencial para que os objetivos da obediência e da disciplina sejam alcançados pela escola.

A instituição inspeciona o tempo e o espaço dos alunos, os custodia, os supervisiona e os disciplina, administrando, mediante esses recursos, a infância e a adolescência. Além disso, conta com uma estrutura de prêmios e castigos que tanto serve

449 CORRÊA, Guilherme. Um corpo para a tolerância. In: PASSETTI, Edson; OLIVEIRA, Salete (Orgs.). A intolerância e o intempestivo. Cotia: Ateliê Editorial, 2005. p. 179.

450 KRUPPA, Sonia M. Portella. Sociologia da educação. São Paulo: Cortez, 1994.

451 CASTRO, Lola Aniyar de. Criminologia da libertação. Tradução de Sylvia Moretzsohn. Rio de Janeiro: Revan, 2005. 
para motivar quanto para excluir o aluno, a depender de como ele se coloca na escola. ${ }^{452}$ Nesse contexto, o mau comportamento, a desobediência ou, em outros termos, a inadaptação ou o inconformismo do estudante em relação às regras escolares podem servir como justificativas para o tratamento que ele recebe.

Dada a reação da instituição diante de um ato indesejado por parte do aluno, fica claro que "a escola reserva a instrução para aqueles cujos passos na aprendizagem se ajustam a medidas previamente aprovadas de controle social”. 453

Desconsidera-se que, muitas vezes, a violência perpetrada pelo estudante contra seus professores, contra o corpo diretivo do estabelecimento ou mesmo a dirigida contra seus colegas

seria apenas a conduta mais visível de recusa ao conjunto de valores transmitidos pelo mundo adulto, representados simbólica e materialmente na instituição escolar, que não mais respondem ao seu universo de necessidades. Outras modalidades de resposta, talvez as mais frequentes, se exprimem no "retraimento" e na "indiferença": os alunos estão na escola, mas são pouco permeáveis à sua ação. ${ }^{454}$

As regras de convivência no ambiente não são discutidas pelos alunos, mas resultam de imposição da direção do estabelecimento de ensino, o que evidencia a negação da autonomia desses sujeitos efetivada exatamente no lugar responsável por sua emancipação ${ }^{455}$ Organizar-se em filas, não correr, cantar o hino nacional, observar os horários são atividades impostas, muitas vezes, sem nenhuma finalidade, apenas como reforço do poder de disciplinamento emanado da escola, pois tudo é feito para que a ordem

452 CASTRO, Lola Aniyar de. Criminologia da libertação. Tradução de Sylvia Moretzsohn. Rio de Janeiro: Revan, 2005.

453 ILLICH, Ivan. Sociedade sem escolas. 4. ed. Tradução de Lúcia Mathilde Endlich Orth. Petrópolis: Vozes, 1973. p. 36.

454 SPOSITO, Marília Pontes. Violência e escola: as múltiplas faces de uma relação. In: PACHECO, Elza Dias (Org.). O cotidiano infantil violento: marginalidade e exclusão social. São Paulo: Lapic: L’Editora: Fapesp, 2007. p. 63.

455 Conforme assevera Chaluh, "a autonomia relaciona-se às relações efetuadas pelos sujeitos como criadores das leis e regras. Os sujeitos têm a possibilidade de conhecê-las e interpretá-las. Observou-se, então, que é possível favorecer a autonomia nos alunos no momento em que eles têm possibilidade de organizar o seu dia e decidir por si mesmos o quê fazer e como fazer as atividades”. Cf. CHALUH, Laura Noemi. Educação e diversidade: um projeto pedagógico na escola. Campinas: Alínea, 2006. p. 152. 
seja mantida, já que lá existe uma espécie de obsessão pela ordem, a qual, “quando não é livremente desejada ou consentida, converte-se de imediato no problema da autoridade e da submissão à mesma”. 456

Analisando o fundamento dessa disciplina, evidencia Corrêa que

o cumprimento cotidiano de tarefas seguidas, sempre, de verificações e valorações externas quer produzir um cidadão trabalhador, e para isso somos recolhidos às escolas quando crianças e mantidos lá, sob força da lei, pelo menos durante boa parte da nossa juventude. ${ }^{457}$

No mesmo sentido também assevera Kruppa que

as regras de funcionamento da escola muitas vezes se distanciam do objetivo de formar sujeitos críticos, portadores de conhecimento e de atitudes necessárias para transformar a realidade, objetivo invariavelmente mencionado em todas as propostas escolares. [...]. Se na escola estas regras se distanciaram do objetivo pelo qual elas foram criadas, podemos dizer que a instituição escolar se tornou uma instituição burocratizada. [...]. Esvaziadas de sentido, as regras da escola passam a exercer apenas um papel disciplinador. ${ }^{458}$

Além da determinação das regras de conduta, a cultura oferecida pelo currículo também é unilateral, não respeita as diferentes capacidades dos alunos, funcionando, pois, como mecanismo de normalização e homogeneização dos estudantes, pela definição e pelo reforço da unidimensionalidade dos valores e dos saberes.

Diante do currículo apresentado só resta ao aluno obedecer e aprender o que a escola determinou que ele deve saber.

Desse modo, “um ensino que privilegia o que é útil segundo um critério instrumental, de eficiência, de retorno, conteúdos superficiais, além dos meios de

456 ENGUITA, Mariano Fernández. A face oculta da escola: educação e trabalho no capitalismo. Tradução de Tomaz Tadeu da Silva. Porto Alegre: Artes Médicas, 1989. p. 164.

457 CORRÊA, Guilherme. Um corpo para a tolerância. In: PASSETTI, Edson; OLIVEIRA, Salete (Orgs.). A intolerância e o intempestivo. Cotia: Ateliê Editorial, 2005. p. 183.

458 KRUPPA, Sonia M. Portella. Sociologia da educação. São Paulo: Cortez, 1994. p. 100. 
comunicação favorecem a transmissão de uma cultura homogênea, esquecendo, assim, os valores humanos". 459

De todo modo, importante perceber que a escola tem a peculiaridade de emitir mensagens que devem ser aprendidas, sendo que se retorna sempre a esses conteúdos para que sejam eles memorizados pelos estudantes, o que fortalece extraordinariamente o exercício do controle.

Por sua vez, no que se refere à atuação do professor, tem-se que ele firma seu saber a partir de cima, como se essa fosse a única opção a ser considerada, minando, desse modo, um posicionamento crítico e de diálogo com o estudante, por meio da desconsideração da sua opinião e da sua vivência.

Fato é que os professores são tradicionalmente conservadores e "como agentes da ordem e da disciplina, são, por sua vez, exemplo vivo dos estereótipos valorativos da sociedade estabelecida. Os professores tendem a rotular os marginais e não compreendem suas dificuldades originárias”. 460

Nesse diapasão,

o preconceito em sala de aula, por exemplo, tem justificado atitudes de professores em separar alunos "lerdos" dos "inteligentes" ou "espertos", compreender a diferença no ritmo da aprendizagem entre os alunos como um sintoma de distúrbio de aprendizagem, como se as condições vividas pelas pessoas fossem iguais, e, portanto, as respostas às estimulações devessem ser homogêneas. Junto com estas concepções, estarão presentes as intolerâncias ao diferente, à loucura, gerando o preconceito, a discriminação e outras formas de exclusão. ${ }^{461}$

459 CHALUH, Laura Noemi. Educação e diversidade: um projeto pedagógico na escola. Campinas: Alínea, 2006. p. 150.

460 CASTRO, Lola Aniyar de. Criminologia da libertação. Tradução de Sylvia Moretzsohn. Rio de Janeiro: Revan, 2005. p. 164.

461 ZONTA, Celso. Igualdade/desigualdade: significações e sentidos no contexto da Psicologia. In: CARDOSO, Clodoaldo Meneguello (Org.). Convivência na diversidade: cultura, educação e mídia. Bauru: Unesp; FAAC, 2008. p. 33. 
Mais uma vez, a imposição da ordem fica clara. O aluno não deve questionar o professor, mas apenas absorver - passivamente - seus ensinamentos.

O sistema de notas, adotado como critério seguro da verificação da aprendizagem na grande maioria das escolas, funciona como a institucionalização da injustiça.

O número atribuído ao estudante lhe impõe um rótulo, determina sua qualidade como aluno e o tratamento que deve receber do corpo docente e discente, influenciando, sobremaneira, a recepção que esse indivíduo receberá na interação social.

Agindo assim, tratando de maneira formalmente igualitária seus alunos e exigindo deles os mesmos resultados, a instituição acaba por ignorar as identidades coletivas dos estudantes e suas dificuldades específicas.

\section{Sendo assim, fica evidente que}

a escola tem grande peso na aceitação conservadora das ideias liberais. Se sustentada por princípios exclusivamente individualizantes, pela classificação e avaliação, a escola acaba por rotular os indivíduos como capazes ou não segundo o aproveitamento de cada um, deixando de ver o aluno como um ser social e histórico.

Neste caso, a escola se isola da sociedade. Diz trabalhar apenas no nível das ideias, afirmando uma igualdade aparente, que não leva em conta as desigualdades sociais e econômicas. Esse modelo de escola acaba tratando desiguais social e economicamente como iguais, reproduzindo a igualdade apenas formal do sistema social, onde todos são iguais perante a lei, embora vivam em profundas desigualdades de condições. ${ }^{462}$

Por tudo isso é que Baratta defende a existência de uma complementaridade entre as funções exercidas pela escola e pelo sistema penal, uma vez que ambos colaboram na conservação da realidade social.

Nesse sentido, revela o autor que

a homogeneidade do sistema escolar e do sistema penal corresponde ao fato de que realizam, essencialmente, a mesma função de reprodução das

462 KRUPPA, Sonia M. Portella. Sociologia da educação. São Paulo: Cortez, 1994. p. 52-53. 
relações sociais e de manutenção da estrutura vertical da sociedade, criando, em particular, eficazes contraestímulos à integração dos setores mais baixos e marginalizados do proletariado, ou colocando diretamente em ação processos marginalizadores. Por isso, encontramos no sistema penal, em face dos indivíduos provenientes dos estratos sociais mais fracos, os mesmos mecanismos de discriminação presentes no sistema escolar. $^{463}$

Em consonância com esse entendimento explica Shecaira que esse fenômeno “decorre de um mecanismo de reprodução das relações sociais e de marginalização, que é ultrapassado por filtros sucessivos que levam a população excluída de um sistema para o outro". ${ }^{464}$

Em virtude de todas as relações que engendra é que a escola mostra-se altamente contraditória. Ao mesmo tempo que ela reproduz e aprofunda a desigualdade nas interações sociais, colaborando com a segregação dos vulneráveis, “é justamente no campo de atuação da escola, como meio de controle social, ou seja, na formação dos cidadãos, que políticas de redução da criminalidade podem ser mais efetivas e menos invasivas”. 465

Assim, pensar a educação requer a indicação de seus infortúnios e também de suas potencialidades, tendo em vista que avaliar seu potencial conservador ou progressista demanda compreender que tipo de educação e de escola que se está a analisar. ${ }^{466}$

Miralles, ao contrapor organização social e escola, assevera que as sociedades atuais impedem a emancipação dos cidadãos, pois se organizam com base na desigualdade entre os indivíduos e na limitação à sua liberdade, ao impedir que eles tomem consciência de sua vivência.

463 BARATTA, Alessandro. Criminologia crítica e crítica do direito penal: introdução à sociologia do direito penal. Tradução de Juarez Cirino dos Santos. 2. ed. Rio de Janeiro: Freitas Bastos, 1999. p. 175.

464 SHECAIRA, Sérgio Salomão. Sistema de garantias e o direito penal juvenil. São Paulo: Revista dos Tribunais, 2008. p. 136.

465 SICA, Ana Paula Zomer. Prevenção Criminal: análise de políticas extrapenais. Rio de Janeiro: Lumen Juris, 2009. p. 79.

466 CARDOSO, Franciele Silva. A luta e a lida: estudo do controle social do MST nos acampamentos e assentamentos de reforma agrária. São Paulo: IBCCrim, 2012. 
Nessa sociedade cada um deve ter o seu papel - o proprietário e o não proprietário - e as agências de controle social informal atuam para assegurar que cada um se conforme com seu lugar social. Em outras palavras, são "as instâncias de controle que interiorizam em cada indivíduo a disciplina social que dele se exige”. ${ }^{467}$

O colégio reproduz a normalização de cada um a seu papel social, incluindo quem se adapta e excluindo os inadaptados. Assim, “o educando deve adquirir os conhecimentos, absorver as atitudes, modelar uma linguagem e uns símbolos sem se permitir a menor postura de crítica ou de rechaço que se tacha de rebelião”. 468

Ocorre que, quando elas falham, entram em funcionamento as instâncias formais de controle social, que exercem a mesma função das informais, mas agora coercitivamente.

\subsubsection{Será a escola uma instituição total?}

Antes de responder à questão de se a escola é uma instituição total, é preciso, em primeiro lugar, elucidar as suas características. Para tal desiderato, recorrer-se-á às contribuições de Goffman, autor que aprofundou o estudo das citadas instituições em sua obra Manicômios, prisões e conventos. ${ }^{469}$

Para Goffman, as instituições totais caracterizam-se por aglutinar em um mesmo ambiente as atividades de dormir, brincar e trabalhar; por seu caráter binário, que se refere à existência em seu bojo de dois grandes grupos, o dos controlados e os controladores, os quais exercem sua tarefa por um sistema burocratizado; a supressão da família, com o objetivo de fortalecer os laços do indivíduo com a instituição; ter tendência ao fechamento por meio, por exemplo, de muros e proibição de saída; existência de um grupo relativamente grande de pessoas que acompanha o sujeito em todas as atividades que

467 MIRALLES, Teresa. El control informal. In: BERGALLI, Roberto; BUSTOS RAMÍREZ, Juan (Dir). El pensamiento criminológico: Estado y control. Bogotá: Temis, 1983. v. 2, p. 37-62, especialmente p. 39.

468 Idem, ibidem, p. 47.

469 GOFFMAN, Erving. Manicômios, prisões e conventos. Tradução de Dante Moreira Leite. 7. ed. São Paulo: Perspectiva, 2005. 
realiza; execução das tarefas em horários preestabelecidos; e ter todas as atividades obrigatórias estabelecidas em um plano racional único, elaborado para atender aos fins da instituição.

Ademais, a entrada numa instituição total pressupõe que o sujeito perpasse diversos processos de mortificação do eu, tais quais a separação entre o mundo externo e interno que impõe, a qual provoca o despojamento do papel que o sujeito ostentava do lado de fora; o processo de admissão na instituição - a entrega dos objetos pessoais, o recebimento do uniforme, o corte do cabelo, o banho, a instrução quanto às regras do local, o recebimento de um número de registro que pode substituir o uso do nome - constitui uma segunda mortificação do eu, ao enquadrar o interno no padrão exigido pela administração e despi-lo de seu conjunto de identidade; também a perda de um sentido de segurança pessoal, desenvolvendo-se um constante sentimento e sensação de ameaça a sua integridade física. $^{470}$

Sobre os processos de admissão do indivíduo na instituição, afirma Goffman que eles

talvez pudessem ser denominados "arrumação" ou "programação", pois, ao ser "enquadrado", o novato admite ser conformado e codificado num objeto que pode ser colocado na máquina administrativa do estabelecimento, modelado suavemente pelas operações de rotina. ${ }^{471}$

Aliados a estes, existem ainda processos de mortificação menos diretos, como, por exemplo, o que inclui violação da autonomia do sujeito.

Nas instituições totais o indivíduo sequer pode programar-se da maneira que deseja, pois todas as suas atividades estão sujeitas a regulamentos e julgamentos dos dirigentes. Alia-se a isso o fato de ele ter de pedir permissão para a realização de tarefas secundárias, como utilizar o banheiro.

470 GOFFMAN, Erving. Manicômios, prisões e conventos. Tradução de Dante Moreira Leite. 7. ed. São Paulo: Perspectiva, 2005.

471 Idem, ibidem, p. 26. 
Note-se, pois, que essas instituições, além de limitarem profundamente a liberdade do interno, ainda esforçam-se para disciplinar todos os aspetos de sua vida. Tudo é controlado pela instituição, sendo que só resta ao sujeito adaptar-se às regras do jogo.

Analisando os atributos acima mencionados, percebe-se que a escola não pode ser identificada com as instituições totais precipuamente pelo fato de não se apropriarem das atividades de trabalho, lazer e de dormir de seus alunos. Por outro lado, fica evidente também que algumas características da escola a aproximam, sim, das instituições totais.

A escola, tal qual a instituição total, abriga, de maneira obrigatória, certa parcela da população.

Nesse sentido, assevera Enguita que

nenhuma outra instituição social, exceto os exércitos de serviço obrigatório - que não existem em todos os países nem afetam o gênero feminino - apresenta esta característica de enquadramento obrigatório de toda a população. Outras instituições totais, das quais os internos não podem se livrar, tais como as prisões e os manicômios, afetam apenas a grupos proporcionalmente reduzidos - embora já se tornem bastante amplos - da população. ${ }^{472}$

Outrossim, a burocratização da atividade de controle, a exigência de ordem e disciplina, o desrespeito à autonomia do indivíduo, o estabelecimento de horários, o uso do uniforme, a imposição de atividades obrigatórias, o convívio forçado com o grupo de coetâneos, todas essas são atividades comuns à escola e às instituições totais.

Os estudantes são mantidos em constante interação e vigilância pelos agentes da escola, sendo que todo seu trabalho é realizado visando a modelar as dimensões cognitivas, o comportamento e o caráter dos alunos, por intermédio da organização sistemática da experiência, da vida prática dos estudantes. ${ }^{473}$

\footnotetext{
472 ENGUITA, Mariano Fernández. A face oculta da escola: educação e trabalho no capitalismo. Tradução de Tomaz Tadeu da Silva. Porto Alegre: Artes Médicas, 1989. p. 157.

473 Idem, ibidem.
} 
Ambas as instituições, pois, agem para moldar um indivíduo disciplinado, ambas têm obsessão pela ordem e pela disciplina, já que alcançá-las faz parte da consecução de seus objetivos.

Desse modo, é possível afirmar que “a escola é uma espécie de instituição total de tempo parcial, cujos internos contam com tardes livres, fins de semana e férias anuais". ${ }^{474}$

Assim, sem chegar a ser uma instituição total, a escola aproxima-se dela ao pretender controlar o corpo e a alma dos jovens que abriga.

\subsection{Uma explicação para a efetividade do controle social informal: a teoria dos vínculos sociais}

Conforme já tratado neste Capítulo, o controle social informal é capaz de moldar condutas e incutir ideias e valores sobre os controlados. Sendo assim, ele atua também na prevenção das condutas indesejáveis.

Hirschi apresenta no ano de 1969, em sua obra Causes of delinquency, uma explanação sobre o controle social informal denominada teoria dos vínculos sociais ou do controle, aplicada na explicação da criminalidade juvenil. ${ }^{475}$

De acordo com essa teorização, o que inibe o sujeito de praticar condutas proibidas são os vínculos afetivos que ele estabelece, por exemplo, com os pares, com a família e com a escola. É a sua imersão em redes de contato e de apoio social que favoreceria o controle de suas ações.

Nesse diapasão, “o pressuposto central da teoria do controle ou dos vínculos sociais de Hirschi estabelece que a existência de vínculos afetivos com pessoas

474 ENGUITA, Mariano Fernández. A face oculta da escola: educação e trabalho no capitalismo. Tradução de Tomaz Tadeu da Silva. Porto Alegre: Artes Médicas, 1989. p. 157.

475 Entre os criminólogos do controle podem ser citados também Albert J. Reiss e Ivan F. Nye, apesar de o trabalho de Hirschi ter obtido o maior destaque. 
socialmente integradas constitui o principal elemento que retém os jovens de envolver-se em atividades delitivas”. 476

Nas palavras do idealizador da ideia, "na medida em que a criança respeite (ame e tema) a seus pais e aos adultos em geral, ela aceitará suas regras. De modo contrário, na medida em que o respeito se faça socavado, as regras tenderão a perder seu caráter obrigatório". 477

Entende-se que o crime acontece devido à inexistência ou à ruptura de vínculos contrários a sua prática. Nesse diapasão, “os teóricos do controle, valendo-se de uma análise sociológica, sustentam que não é o medo do castigo o fator fundamental no momento de explicar o comportamento do infrator, senão muitos outros vínculos entre ele e a ordem social”. 478

Assim, visando a elucidar sua proposta Hirschi afirma que não enxerga a desviação como problemática e que sua intenção é apenas compreender por que o indivíduo a praticou e por que os demais não o fizeram também. ${ }^{479}$

Para a teoria do controle ou dos vínculos sociais são quatro os elementos que dissuadem a prática do crime: o apego, o compromisso, a participação e as crenças do sujeito.

Importante consignar, desde já, que para o autor a falta dessas relações torna a delinquência possível e não necessária, ${ }^{480}$ o que desvincula a teoria de qualquer pretensão determinista em relação ao crime.

476 GARRIDO, Vicente; STANGELAND, Per; REDONDO, Santiago. Principios de Criminología. 2. ed. Valência: Tirant lo Blanch, 2001. p. 218.

477 HIRSCHI, Travis. Una teoría del control de la delincuencia. Capítulo Criminológico, Maracaibo, v. 31, n. 4, p. 5-31, out.-dez. 2003. p. 24.

478 GARCÍA-PABLOS DE MOLINA, Antonio. O que é Criminologia? Tradução de Danilo Cymrot. São Paulo: Revista dos Tribunais, 2013. p. 134.

479 HIRSCHI, Travis. Una teoría del control de la delincuencia. Capítulo Criminológico, Maracaibo, v. 31, n. 4, p. 5-31, out.-dez. 2003.

480 HIRSCHI, Travis. Causes of deliquency. New Brunswick: Londres: Transaction, 2001. 
O apego refere-se aos laços emocionais que se estabelecem com os outros e que tornam possível afeto, admiração e identificação. Quanto mais firmes forem essas relações, menores as possibilidades de o indivíduo praticar um ato desviante. Em contrapartida, quanto mais frágeis esses vínculos, maiores as chances dele delinquir.

Para Hirschi, o fato de o indivíduo alienar-se dos demais sempre envolve ou baseia-se em um conflito interpessoal. Nesse diapasão, defende que um homem divorciado é mais propenso a praticar atos inadequados após seu divórcio, como falsificação ou mesmo o suicídio. ${ }^{481}$

O compromisso evidencia o comprometimento que a pessoa tem com a sociedade convencional.

As pessoas investem seu tempo e sua energia na consecução de determinadas atividades laborativas, de estudo ou mesmo na construção de uma reputação virtuosa. Caso elas pratiquem um crime, sabem que o custo dessa conduta será alto, pois perderão tudo que se esforçaram para ter. ${ }^{482}$

Desse modo, quanto mais compromissos o sujeito assumir ao longo de sua vida, mais difícil será delinquir.

Note-se que tal assertiva indica que para as teorias do controle a decisão de praticar um crime pode ser racionalmente determinada.

A participação evidencia a implicação do indivíduo com as atividades convencionais, como a família, a escola e o trabalho.

A ideia aqui é de que a pessoa gasta tanto tempo engajada em atividades socialmente aceitas que não lhe sobra tempo de praticar outras ilícitas. ${ }^{483}$

\footnotetext{
481 HIRSCHI, Travis. Causes of deliquency. New Brunswick: Londres: Transaction, 2001.

482 Idem, ibidem.

483 Idem.
} 
Hirschi assevera que essa afirmação é tão evidente que outros criminólogos também concordam com ela.

Nesse sentido afirma Sutherland que a melhor maneira de prevenir os atos delinquenciais é estimular o indivíduo a estabelecer relações sociais neutras. ${ }^{484}$

Trata-se da realização de atividades valorativamente imparciais que não estimulam nem a infração nem a observância de leis, mas apenas minimizam as possibilidades de o sujeito envolver-se em atos ilícitos, por estar ocupado com a realização de outras tarefas.

Entre essas atividades podem ser citadas, exemplificativamente, a pintura, o artesanato ou o desporto.

Por fim, as crenças se referem aos conjuntos de valores que o sujeito adota em consonância com os estabelecidos socialmente. ${ }^{485}$

Hirschi acredita na adoção de um sistema de valores comum na sociedade ou no grupo do qual o indivíduo faz parte, sendo que ao violar uma dessas normas o sujeito desrespeita uma regra com a qual ele anuiu, na qual ele mesmo acredita.

Assim, a questão que se coloca diante de tal atitude é a de "por que um homem viola as regras nas quais ele crê?” e não “por que os homens diferem em suas crenças sobre o que constitui uma conduta boa e desejável?”. ${ }^{486}$

Para Hirschi, ainda mais importante, na explicação da delinquência, que os elementos acima citados são as combinações entre eles, especificamente as que relacionam apego e compromisso, compromisso e participação e apego e crença.

484 SUTHERLAND, Edwin H. Princípios de Criminologia. Tradução de Asdrúbal Mendes Gonçalves. São Paulo: Livraria Martins, 1949.

485 GARRIDO, Vicente; STANGELAND, Per; REDONDO, Santiago. Principios de Criminología. 2. ed. Valência: Tirant lo Blanch, 2001.

486 HIRSCHI, Travis. Causes of deliquency. New Brunswick: Londres: Transaction, 2001. p. 23. 
Como o autor propõe-se estudar a delinquência juvenil, a ênfase na escola é um foco importante de sua teorização.

A esse respeito, Hirschi menciona uma ambiguidade fundamental existente entre ela - instituição de classe média - e os jovens de classe baixa, em relação à delinquência. Assim, nas palavras do autor:

porquanto a escola é uma instituição manifestamente de classe média e a delinquência foi por muito tempo considerada um fenômeno predominantemente da classe baixa, a grande alavanca para forçar abrir os segredos da escola na produção da delinquência tem sido avaliar seu impacto sobre as crianças de classe baixa. ${ }^{487}$

Para o autor essa aproximação pode tomar dois caminhos principais. De um lado, o jovem de classe baixa tem de lidar, na escola, com um problema de adaptação. Sua experiência na instituição é desprazerosa, degradante e desmoralizante, os professores tendem a punir sua inquietação e falta de ambição e os colegas da classe média recusam-se a namorá-los ou a deixá-los integrar seus grupos.

De outro lado, como as relações estabelecidas no ambiente escolar lhe são desfavoráveis, a relação entre a educação e a possibilidade de mobilidade social torna-se foco de sua atenção e a impossibilidade de isso acontecer é uma das razões principais a empurrar-lhe para a delinquência.

Hirschi ressalta ainda a importância de outros fatores ligados à escola na determinação da delinquência, os quais foram identificados em seus estudos práticos.

Menciona, nesse sentido, que os estudantes com pouca competência acadêmica e também cujo desempenho escolar é ruim têm mais tendência a praticar delitos, sendo que o mesmo ocorre quando o aluno não gosta da instituição. Inversamente, porém, habilidade e boa performance se relacionam a atitudes favoráveis em relação à escola, fortalecendo o vínculo do estudante com ela e tornando a delinquência menos provável.

487 HIRSCHI, Travis. Causes of deliquency. New Brunswick: Londres: Transaction, 2001. p. 110. 
Desse modo, a teorização proposta pelo autor mostra sua validade também no âmbito escolar: enfraquecido o vínculo do aluno com a escola, maiores as chances de o ilícito tornar-se atrativo para ele. 


\section{CONSIDERAÇÕES FINAIS}

Esta tese confrontou-se, ao longo de seu desenvolvimento, com inúmeros desafios. Diversas questões fizeram-se pertinentes, sendo necessário, neste espaço, ponderar sobre todas elas.

Antes de tudo, mister destacar que o bullying escolar é uma violência, é uma das tantas manifestações que o comportamento violento encontra.

Isso implica reconhecer que ocorrências de agressões físicas e verbais, repetidamente praticadas contra alguém, dentro de uma relação de desequilíbrio de poder, não são parte da organização normal das escolas, sendo, em contrapartida, problemas que devem ser solucionados.

E sendo a violência um fenômeno social e cultural, fez-se necessário compreendê-la dentro das estruturas da sociedade e do espaço escolar que a suportam.

Nesse sentido, o que se verificou é que as organizações sociais, ao definirem um conjunto hermético de padrões de comportamento e de aparência, acabam estimulando o rechaço a tudo que não se coaduna com os parâmetros estabelecidos. É daí que emerge o bullying escolar.

O bullying, pois, tem uma razão de ser que é social. É a intolerância, a não aceitação do outro, por ser ele diferente do que se considera adequado, que faz com que as agressões físicas e psicológicas repetidamente aconteçam. Assim, ser mais retraído, não ter as roupas da moda, ser muito baixo, ser muito alto, ser muito magro, ser muito gordo, usar óculos, ter os cabelos rebeldes, enfim, essas simples e inofensivas características fazem nascer a violência.

Nesse diapasão, invade a escola um problema que é social, mas que naquele ambiente acaba ganhando configurações e proporções únicas.

Na sociedade é possível evitar contatos indesejados, diminuir as possibilidades de ver e conviver com pessoas ou grupos sociais minoritários, atitude discriminatória e que 
certamente enfraquece os laços de solidariedade social, mas que, não necessariamente, culmina num conflito aberto entre os envolvidos. Contudo, na escola, o convívio com os outros estudantes é imposto, não há possibilidade de se esquivar do encontro não querido, razão pela qual o confronto tem maiores possibilidades de acontecer e, muitas vezes, efetivamente ocorre.

Diversas análises foram feitas sobre o bullying escolar colocando o jovem como o único responsável pelas agressões. Curiosamente, muitos diretores atribuem a ocorrência dos confrontos às características pessoais dos alunos, tidos como muito conflitivos ou intolerantes, isentando a escola de responsabilidades em relação à convivência de seus alunos.

Debarbieux confirma essa assertiva ao defender que "a polêmica maneira de abordar a questão da intimidação por colegas nem sempre escapou de um enfoque excessivo nos aspectos psicológicos e no indivíduo, nos padrões e nos traços de caráter, sem colocar em questão os sistemas educacional e político”. ${ }^{488}$

O perigo dessas apreciações centradas somente no agressor é que elas levam a crer que se ele não existisse o problema também desapareceria, o que pode estimular práticas higienistas e discriminatórias. Nesses termos, a solução de um problema criaria outro ainda maior, ou pelo menos, de iguais proporções.

Em contrapartida, entender o bullying escolar como algo que decorre das estruturas sociais e escolares implica aceitar que a eliminação do perpetrador das agressões não minimiza o problema, pois a própria conjuntura social faz brotar, a todo tempo, novos bullies.

Nesse sentido,

a violência, diríamos, por tudo que é possível constatar e demonstrar, é um artefato da cultura e não seu artífice. Ela é uma particularidade do viver social, um tipo de "negociação", que através do emprego da força

488 DEBARBIEUX, Éric. "Violência nas escolas": divergências sobre palavras e um desafio político. In: DEBARBIEUX, Éric; BLAYA, Catherine (Orgs.). Violência nas escolas e políticas públicas. Tradução de Patrícia Zimbres. Brasília: Unesco, 2002. p. 73. 
ou da agressividade, visa encontrar soluções para conflitos que não se deixam resolver pelo diálogo e pela cooperação. ${ }^{489}$

Importante perceber, então, que "quanto mais aprimorada culturalmente for uma sociedade, maior será o nível de tolerância. Isso corresponderá ao enriquecimento de uma cultura democrática fundamentada no respeito pelas diferenças do outro”. 490

Vale também destacar que identificar a importância de um problema não significa ter de estender suas dimensões. Nesse diapasão, mister aclarar que o bullying nas escolas existe, atrapalha o desenvolvimento das relações escolares, mas tem uma extensão menor do que os meios de comunicação costumam asseverar.

Conforme se demonstrou na presente tese, os números da violência escolar ainda são pequenos e os atos praticados dificilmente superam a agressão verbal, o que deve ser tomado como um estímulo ao seu estudo, visando a prevenir a dissipação dessa violência.

Note-se que como “a construção da violência é lenta significa também que a prevenção tenha que começar cedo, devendo acontecer em meio às tarefas cotidianas da educação, e não apenas nas grandes campanhas de 'conscientização', por mais úteis que elas possam ser". 491

Diante de um conflito social, muitas vezes o que se exige é a presença do direito penal, considerado o único instrumento capaz de combater a violência. Porém, sua efetividade é mais simbólica do que real e o recurso a ele não resolverá o bullying escolar, pois ao estigmatizar os envolvidos numa disputa, a norma penal só consegue fortalecer a diferença que no início gerou o problema.

489 COSTA, Jurandir Freire. Violência e psicanálise. 3. ed. são Paulo: Graal, 2003. p. 62. multiculturalismo e as diversidades para viver uma cultura democrática. Revista Mestrado em Direito, Osasco, v. 12, n. 1, p. 199-227, jan.-jul. 2012. p. 225.

491 DEBARBIEUX, Éric. "Violência nas escolas": divergências sobre palavras e um desafio político. In: DEBARBIEUX, Éric; BLAYA, Catherine (Orgs.). Violência nas escolas e políticas públicas. Tradução de Patrícia Zimbres. Brasília: Unesco, 2002. p. 86. 
Nesse caso, a lei pode incitar a transgressão. Faz com que a violência na escola se manifeste de modo recorrente e com que não se trabalhe a questão institucional, o que se passa na sala de aula e nos corredores da escola. ${ }^{492}$

Por isso que

o recurso a via penal - ainda que consista esta em um processo especialmente desenhado para menores infratores - deve ser sempre a ultima ratio na resolução do conflito surgido. [...] Em consequência, se considera que o primeiro nível de luta contra o bullying se encontra, em todo caso, no próprio âmbito escolar. ${ }^{493}$

É, pois, na escola que as soluções têm de ser buscadas. A negociação dos conflitos por meio do estímulo ao diálogo - realizado numa perspectiva simétrica - é que tem força de fazer emergir uma resposta que a todos beneficie. Nesse sentido, o trabalho pedagógico deve ser dirigido ao empoderamento do estudante no uso de sua capacidade de falar.

Assim,

embora a escola esteja muito preocupada com o aproveitamento intelectual, precisa criar oportunidades para crianças e adolescentes observarem e praticarem a capacidade de relacionamento social, como conviver com os seus colegas e resolver situações-problemas. Não basta os alunos falarem, é preciso ver exemplos, praticar e obter retorno das competências desenvolvidas e obter consequências positivas da aprendizagem quando os alunos utilizam estas competências na interação com colegas e alunos. ${ }^{494}$

No entanto, não se pode se iludir acerca da possibilidade e do interesse das escolas em solucionar o problema.

Nas palavras de Zaffaroni, a Criminologia

492 DEFRANCE, Bernard. La violence à l'école. 7. ed. Paris: La Découverte, 2009.

493 MARTÍN RÍOS, Maria Del Pilar. Aspectos procesales del tratamiento en España del bullying o acoso escolar. Revista de Derecho e Proceso Penal, Navarra, n. 29, p. 13-23, set.-dez. 2012. p. 15.

494 GOMES, Candido Alberto. A educação em novas perspectivas sociológicas. 4. ed. São Paulo: EPU, 2005. p. 117. 
é o saber (conjunto de conhecimentos) que nos permite explicar como operam os controles sociais punitivos de nossa margem periférica, que condutas e atitudes promovem, que efeitos provocam e como se os encobre enquanto isso seja necessário ou útil para projetar alternativas às soluções punitivas ou soluções punitivas alternativas menos violentas que as existentes e mais adequadas ao progresso social. ${ }^{495}$

Contudo, ela tem realmente se preocupado em denunciar os interesses que se escondem por detrás da atuação do sistema de controle social formal, sem, porém, dedicar a mesma atenção ao controle social informal.

O comando das instituições de ensino é um instrumento de poder que se exerce na realização do controle social informal e, nesse âmbito, pode assumir papéis contraditórios.

Ao mesmo tempo que as agências do controle social informal são mais eficazes na tarefa de evitar a ocorrência de comportamentos indesejáveis, impedindo, assim, que o sistema penal seja chamado a intervir, elas também servem aos interesses da classe social dominante, colaborando no aprofundamento, ou pelo menos na mantença, das relações sociais desiguais. E a escola mostra essa sua faceta quando impõe saberes e valores aos estudantes, sem possibilitar que eles questionem a pertinência do conhecimento, quando exige obediência diante de regras de comportamento unilateralmente aprovadas e quando determina a qualidade dos alunos apenas com base em seu desempenho acadêmico.

Logo, nota-se que o controle social não é necessariamente ruim, mas ele é péssimo quando mina a autonomia do sujeito, quando usurpa suas ideias e quando trabalha em favor de interesses apenas de uma maioria. Ele não serve à emancipação social quando pretende produzir cidadãos disciplinados, que não questionem a ordem social imposta, tratando-a como mero dever ser.

Diante disso, pergunta-se:

495 ZAFFARONI, Eugenio Raúl. Criminología: aproximación desde un margen. Colômbia: Temis, 1993. p. 20. 
qual seria a escola adequada? Sem dúvida, diante da realidade atual, torna-se premente que qualquer instituição educativa seja aberta à valorização dos interesses, conhecimentos e expectativas dos jovens favoreça sua autoestima e consubstancie o respeito aos seus direitos em práticas e não somente na enunciação de programas e conteúdos; se proponha a motivar, mobilizar e desenvolver conhecimentos que partam da vida dos jovens e demonstre interesse por eles como cidadãos e não somente como objetos de aprendizagem. Deve ser uma instituição flexível, com novos modelos de avaliação e sistemas de convivência que levem em conta a diversidade da condição de ser jovem; que atenda às dimensões do desenvolvimento humano e que os jovens possam aprender o saber sistematizado que faz parte da herança da humanidade. Enfim, deve ser uma instituição capaz de acompanhar e facilitar um projeto de inclusão, o que torna essencial ter os sujeitos no centro dos processos educacionais. $^{496}$

Uma escola que tenha essas como suas únicas funções, certamente conseguirá educar para emancipar.

\section{Conclusão}

Esta tese tratou de unir os ensinamentos da Criminologia e da Educação para investigar o problema do bullying escolar, partindo da constatação de que sua origem deriva da intolerância ao diferente.

De todo o exposto foi possível perceber que a despeito de as pessoas cotidianamente empregarem o termo violência, compreender seu real significado é tarefa bastante tortuosa, uma vez que a expressão é polissêmica e cultural, sendo que cada ramo do saber e cada momento histórico considerado a definem mediante parâmetros e perspectivas diversas. Nesse sentido, destacou-se que a violência não tem apenas um sentido negativo, já que, sob o aspecto da moralidade, ela pode ser encarada positiva ou negativamente. Há ainda violências consideradas justificadas, por vezes até necessárias, como a empregada pelo sistema penal, enquanto outras são vistas como absolutamente incompreensíveis.

496 ANDRADE, Eliane Ribeiro; NETO, Miguel Farah. Juventudes e trajetórias escolares: conquistando o direito à educação. In: ABRAMOVAY, Miriam; ANDRADE, Eliane Ribeiro; ESTEVES, Luis Carlos Gil. Juventudes: outros olhares sobre a diversidade. Brasília: Ministério da Educação, Secretaria da Ação Continuada, Alfabetização e Diversidade; Unesco, 2007. p. 78. 
Outrossim, por muito tempo somente era vista como manifestação do comportamento violento a agressão física, sem que contudo se percebesse que por meio da palavra e da desconsideração do outro se praticam violências talvez até mais dolorosas do que as que deixam marcas no corpo.

De todo modo, mesmo diante das dissonâncias mencionadas, nas sociedades pós-modernas foi possível identificar um aspecto sobrepujante da violência: o fato de ela ser uma resposta à intolerância. Nas sociedades multiculturais defrontar-se com alguém considerado diferente, com pessoas cujos objetivos e crenças são discordantes, é cada vez mais corriqueiro, sendo que uma atitude de intolerância diante dessa situação desemboca no inaceitável conflito aberto, demonstração maior da não aceitação do outro.

Nas escolas, também vislumbrou-se a ocorrência do ato violento. Porém, percebeu-se que o fenômeno não raramente é superdimensionado por ser confundido com outros comportamentos, como a transgressão e a incivilidade.

Constatou-se, então, que nesse ambiente, o bullying é uma das maneiras que a violência encontra para manifestar-se. Episódios de agressões físicas, verbais ou psicológicas contra outro estudante, emergidos de uma relação de desigualdade de poder, caracterizam o problema.

Mais uma vez, aqui também a intolerância ao diferente mostra a sua face.

Diversos estudos foram realizados visando a compreender o bullying nas escolas, a investigar sua ocorrência e a propor ações de embate. Entretanto, nenhum deles se ocupou de aprofundar a análise de um momento anterior que é o do surgimento do problema. E nesse sentido vai a colaboração do presente trabalho.

O que aqui se evidenciou é que o bullying escolar decorre da intolerância diante da diferença do outro. Ao deparar com uma característica física ou comportamental considerada esquisita, fora dos padrões, a resposta ofertada pelo estudante é a violência reiterada, que se pratica por intermédio da agressão, de xingamentos ou do isolamento. 
Nesse sentido, restou claro que o problema não advém da maldade ou da índole ruim de um ou mais alunos, que com desvios comportamentais de origem genética perturbam o restante do grupo. O bullying é um problema social e para entendê-lo foi necessário desvendar os segredos do local onde ele ocorre, no caso do recorte escolhido, a escola.

Demonstrou-se que a instituição de ensino, em virtude da importante função de transmissão do saber que exerce, não excepcionalmente é encarada de maneira ingênua, sem que se atente para o fato de que ela é instrumento do exercício do controle social informal e, desse modo, cumpre outras tarefas que vão além da de educar.

Assim, visando a cotejar criticamente os controles que se realizam sobre os cidadãos, nas interações que estabelecem no dia a dia, estudaram-se os controles sociais formal e informal, deixando claro que, a despeito de aquele ser considerado mais negativo, este não fica indene de críticas.

O controle social formal é profissionalizado e caracteriza-se pela participação do Estado, em quaisquer de seus órgãos. Em contrapartida, o controle social informal atua sem a intervenção direta do Estado e de maneira dissipada, o que torna seus contornos mais embaraçados.

Nesse diapasão, a instituição de ensino, conforme se demonstrou, realiza diversas atividades que visam ao cumprimento de sua função de controle, o qual age para moldar os alunos para que se adequem e aceitem mais facilmente a desigualdade das relações sociais, bem como sejam bons trabalhadores, ou seja, quando provenientes das classes sociais mais desfavorecidas, tornem-se funcionários adaptados ao seu destino.

É por meio da obediência, da ordem e da disciplina que a instituição doutrina seus alunos para que aceitem - sem contestar - os valores sociais nos quais devem crer.

Tudo isso faz com que a escola confunda-se com as instituições totais. A despeito de não enquadrar-se na mencionada definição ela ostenta características que a aproximam do modelo de controle adotado nas instituições totais. 
À escola tem acesso parcela significativa das crianças e adolescentes de dada comunidade e sobre eles exerce sua disciplina mediante, por exemplo, o estabelecimento de regras rígidas, a proibição de saída durante o período de aulas, a exigência de horários e o uso do uniforme, do mesmo modo que o faz a instituição total.

Note-se, pois, que enquanto a escola quer formar cidadãos disciplinados e sem autonomia, a construção de um vínculo positivo com ela impede que o estudante enverede pelas práticas criminosas, o que comprova a sua força como guia na assunção de comportamentos desejáveis.

Por todo o exposto, mister que se lance um olhar crítico sobre a escola, desnudando seus problemas e também suas potencialidades, para que assim ela possa ser aproveitada em tudo o que tem de libertária e rechaçada em tudo o que tem de conservadora. 


\section{BIBLIOGRAFIA}

ABRAMOVAY, Miriam; RUA, Maria das Graças. Violências nas escolas. 4. ed. Brasília: Unesco, 2004.

ABRAMOVAY, Miriam. Violências nos cotidianos das escolas. In: ABRAMOVAY, Miriam (Org.). Escola e violência. 2. ed. Brasília: Unesco, UCB, 2003. p. 67-87.

; LIMA, Fabiano; VARELLA, Santiago. Percepções dos alunos sobre as repercussões da violência nos estudos e na interação social na escola. In: ABRAMOVAY, Miriam (Org.). Escola e violência. 2. ed. Brasília: Unesco, UCB, 2003. p. 89-117.

ADORNO, Theodoro W. Educação e emancipação. Tradução de Wolfgang Leo Maar. Rio de Janeiro: Paz e Terra, 1995.

AKERS, Ronald L. Criminological Theories: introduction and evaluation. 2. ed. Los Angeles: Roxbury, 1997.

ANDRADE, Vera Regina Pereira de. A ilusão da segurança jurídica: do controle da violência à violência do controle penal. 2. ed. Porto Alegre: Livraria do Advogado, 2003.

. Do paradigma etiológico ao paradigma da reação social: mudança e permanência de paradigmas criminológicos na ciência e no senso comum. Revista Brasileira de Ciências Criminais, São Paulo, v. 4, n. 14, p. 276-287, abr.-jun. 1996.

ANDRADE, Eliane Ribeiro; NETO, Miguel Farah. Juventudes e trajetórias escolares: conquistando o direito à educação. In: ABRAMOVAY, Miriam; ANDRADE, Eliane Ribeiro; ESTEVES, Luis Carlos Gil. Juventudes: outros olhares sobre a diversidade. Brasília: Ministério da Educação, Secretaria da Ação Continuada, Alfabetização e Diversidade; Unesco, 2007. p. 57-80.

ANDREUCCI, Álvaro Gonçalves; MANGRICH, Cláudia Souza. Diálogos da tolerância: desafios e impactos na sociedade moderna. Revista de Direito, Florianópolis, n. 1, p. 67-81, jun.-dez. 2006. 
ANITUA, Gabriel Ignacio. Histórias dos pensamentos criminológicos. Tradução de Sérgio Lamarão. Rio de Janeiro: Revan, 2008.

ANTILLANO, Andrés. Cambios en el concepto y uso del control social. Capítulo Criminológico, Maracaibo, v. 38, n. 1, p. 5-34, jan.-mar. 2010.

AQUINO, Júlio Groppa. Diversidade, igualdade e democracia: a educação em questão. In: CARDOSO, Clodoaldo Meneguello (Org.). Convivência na diversidade: cultura, educação e mídia. Bauru: Unesp; FAAC, 2008. p. 89-105.

ARAÚJO, Carla. A violência desce para a escola: suas manifestações no ambiente escolar e a construção da identidade dos jovens. 2. ed. Belo Horizonte: Autêntica, 2004.

ARAUJO, Fernanda Carolina de. A teoria criminológica do labelling approach e as medidas socioeducativas. 2010. 251f. Dissertação (Mestrado em Criminologia) Faculdade de Direito, Universidade de São Paulo, [2010].

BARATTA, Alessandro. Criminologia crítica e crítica do direito penal: introdução à sociologia do direito penal. Tradução de Juarez Cirino dos Santos. 2. ed. Rio de Janeiro: Freitas Bastos, 1999. (Instituto Carioca de Criminologia. Coleção Pensamento Criminológico, 1).

. Defesa dos direitos humanos e política criminal. Discursos Sediciosos, Rio de Janeiro, v. 2, n. 3, p. 57-69, 1997.

- El modelo sociológico del conflicto. In: ELBERT, Carlos Alberto (Dir.). Criminología y sistema penal. Montevidéu: Buenos Aires: IBdeF, 2004. p. 247-273.

. Marginalidade social e justiça. Revista de Direito Penal, Rio de Janeiro, n. 2122, p. 5-25, jan.-jun. 1976.

. Principios del Derecho Penal Mínimo: para una teoría de los Derechos Humanos como objeto y límite de la ley penal. Doctrina Penal: Teoria y Práctica en las Ciencias Penales, Buenos Aires, v. 10, n. 37-40, p. 623-650, 1987.

BARREIRAS, Mariana Barros. Controle social informal x controle social formal. In: SÁ, Alvino Augusto de; SHECAIRA, Sérgio Salomão. Criminologia e os problemas da atualidade. São Paulo: Atlas, 2008. p. 295-320. 
BARRÈRE, Anne; SEMBEL, Nicolas. A sociologia da escola. Tradução de Maria Stela Gonçalves. São Paulo: Loyola, 2006.

BARRETTO, Vicente. Educação e violência: reflexões preliminares. In: ZALUAR, Alba (Org.). Violência e educação. São Paulo: Cortez, 1992. p. 55-64.

BATISTA, Vera Malaguti. A arquitetura do medo. Discursos Sediciosos: crime, direito e sociedade, São Paulo, v. 7, n. 12, p. 99-106, 2002.

BAUMAN, Zygmunt. O mal-estar da pós-modernidade. Tradução de Mauro Gama e Cláudia Martinelli Gama. Rio de Janeiro: Zahar, 1998.

; MAY, Tim. Aprendendo a pensar com a Sociologia. Tradução de Alexandre Werneck. Rio de Janeiro: Zahar, 2010.

BECKER, Howard S. Outsiders: studies in the sociology of deviance. Nova Iorque: The Free Press, 1997.

BERGALLI, Roberto. Control social: sus orígenes conceptuales y usos instrumentales. Revista de Derecho Penal y Criminología, Madrid, n. 2, p. 173-184, 1992.

Crítica a la Criminologia: hacia una teoría crítica del control social en América Latina. Bogotá: Temis, 1982.

BIGLIANI, Carlos Guillermo; MOGUILLANSKY, Rodolfo; SLUZKI, Carlos E. Humilhação e vergonha: um diálogo entre enfoques sistêmicos e psicanalíticos. Tradução de Sandra M. Dolinsky e Marta D. Claudino. São Paulo: Zagodoni, 2011.

BOBBIO, Norberto. Elogio da serenidade e outros escritos morais. Tradução de Marco Aurélio Nogueira. São Paulo: Unesp, 2002.

BOY, Priscila Pereira. Inquietações e desafios da escola: inclusão, violência, aprendizagens e carreira docente. Rio de Janeiro: Wak, 2010.

BRASIL. Constituição (1937). Disponível em: <http://www.planalto.gov.br/ccivil_03/constituicao/constitui\%C3\%A7ao37.htm>. Acesso em: 3 jan. 2014. 
CALHAU, Lélio. O fenômeno bullying: breves considerações criminológicas sobre sua possível relação com algumas práticas da delinquência juvenil. Revista MPMG Jurídico, Minas Gerais, v. 2, n. 7, p. 53-53, out.-dez. 2006.

CAMACHO, Luiza Mitiko Yshiguro. Violência e indisciplina nas práticas escolares de adolescentes: um estudo das realidades de duas escolas semelhantes e diferentes entre si. 2000. 265f. Tese (Doutorado em Educação) - Faculdade de Educação Universidade de São Paulo [2000].

CANDAU, Vera Maria; LEITE, Miriam Soares. Diferença e desigualdade: dilemas docentes no ensino fundamental. In: CANDAU, Vera Maria (Org.). Didática crítica intercultural: aproximações. Petrópolis: Vozes, 2012. p. 139-170.

CARA, Daniel; GAUTO, Maitê. Juventude: percepções e exposição à violência. In: ABRAMOVAY, Miriam; ANDRADE, Eliane Ribeiro; ESTEVES, Luis Carlos Gil. Juventudes: outros olhares sobre a diversidade. Brasília: Ministério da Educação, Secretaria da Ação Continuada, Alfabetização e Diversidade; Unesco, 2007. p. 173191.

CARDOSO, Clodoaldo Meneguello. Fundamentos filosóficos da intolerância. In: CARDOSO, Clodoaldo Meneguello (Org.). Convivência na diversidade: cultura, educação e mídia. Bauru: Unesp; FAAC, 2008. p. 13-28.

. Tolerância: tensão entre diversidade e desigualdade. In: PASSETTI, Edson; OLIVEIRA, Salete (Orgs.). A intolerância e o intempestivo. Cotia: Ateliê Editorial, 2005. p. 45-57.

CARDOSO, Franciele Silva. A luta e a lida: estudo do controle social do MST nos acampamentos e assentamentos de reforma agrária. São Paulo: IBCCrim, 2012.

CARVALHO, Salo de. Criminologia crítica: dimensões, significados e perspectivas atuais. Revista Brasileira de Ciências Criminais, São Paulo, v. 104, n. 21, p. 279-303, set.-out. 2013.

CASCO, Ricardo. Violência, corpo e instituições escolares. In: SAETA, Beatriz Regina Pereira; NETO, João Clemente de Souza; NASCIMENTO, Maria Letícia B. P. 
Infância: violência, instituições e políticas públicas. São Paulo: Expressão \& Arte, 2007.

CASTRO, Lola Aniyar de. Criminologia da reação social. Tradução de Ester Kosovski. Rio de Janeiro: Forense, 1983.

. Criminologia da libertação. Tradução de Sylvia Moretzsohn. Rio de Janeiro: Revan, 2005.

CENCI, Angelo Vitório. Subjetividade, individualismo e formação moral no contexto de sociedades complexas e moralistas. In: TREVISAN, Amarildo Luiz; TOMAZETTI, Elisete Medianeira; ROSSATTO, Noeli Dutra (Orgs.). Diferença, cultura e educação. Porto Alegre: Sulina, 2010. p. 67- 79.

CERLETTI, Alejandro. El concepto de igualdad en lãs políticas educativas: una aproximación filosófico-política. In: TREVISAN, Amarildo Luiz; TOMAZETTI, Elisete Medianeira; ROSSATTO, Noeli Dutra (Orgs.). Diferença, cultura e educação. Porto Alegre: Sulina, 2010. p. 35-45.

CHALUH, Laura Noemi. Educação e diversidade: um projeto pedagógico na escola. Campinas: Alínea, 2006.

CHARLOT, Bernard. A mistificação pedagógica: realidades sociais e processos ideológicos na teoria da educação. 2. ed. Rio de Janeiro: Zahar, 1983.

. Violence à l'école: état de recherches en France et... quelques questions dans une perspective girardienne. In: MARTINEZ, Marie-Louise; SEKNAADJÉ-ASKÉNAZI, José (Orgs.). Violence et éducation: de la méconnaissance à l’action éclairée. 2. ed. Paris: L’Harmattan, 2002. p. 22-35.

CHESNAIS, Jean-Claude. Histoire de la violence. Paris: Robert Laffont, 1981.

CHRISTIE, Nils. A indústria do controle do crime: a caminho dos GULAGs em estilo ocidental. Tradução de Luis Leiria. Rio de Janeiro: Forense, 1998.

. Una sensata cantidad de delito. Tradução de Cecília Espeleta e Juan Iosa. Buenos Aires: Del Puerto, 2004. 
CLÉMENCE, Alain. Violência e incivilidade na escola: a situação na Suíça. In: DEBARBIEUX, Eric; BLAYA, Catherine (Orgs.). Violência nas escolas: dez abordagens europeias. Tradução de Patrícia Zimbres e Paula Zimbres Brasília. Unesco: 2002. p. 223-245.

COHEN, Albert K. Delinquent boys. Londres: Routledge \& Kegan Paul, 1958.

COLLINS, Randall. Violence: a micro-sociological theory. Nova Jersei: Princeton, 2008.

CORRÊA, Guilherme. Um corpo para a tolerância. In: PASSETTI, Edson; OLIVEIRA, Salete (Orgs.). A intolerância e o intempestivo. Cotia: Ateliê Editorial, 2005. p. 177187.

CORTELLA, Mário Sérgio. Recusar a destruição da convivência digna! (valores inadiáveis). In: PASSETTI, Edson; OLIVEIRA, Salete (Orgs.). A intolerância e o intempestivo. Cotia: Ateliê Editorial, 2005. p. 168-176.

COSTA, Álvaro Mayrink da. Raízes da sociedade criminógena. Rio de Janeiro: Lumen Juris, 1997.

COSTA, Claudine Alcoforado Quirino; CAVALCANTI, Renata Vinhaes Vergueiro. Novas configurações familiares entre autenticidade e alteridade. III Seminário de Psicologia e direitos humanos: Direitos humanos para quem? Recife: Edupe, 2007. p. 141-146.

COSTA, Igor Sporch da. Igualdade na diferença e tolerância. Viçosa: UFV, 2007.

COSTA, Yvete Flávio da. Bullying - prática diabólica - direito e educação. Revista de Estudos Jurídicos UNESP, Franca, v. 15, n. 21, p. 359-378, jan.-jun. 2011.

COSTA, Jurandir Freire. Violência e psicanálise. 3. ed. São Paulo: Graal, 2003.

COSTANTINI, Alessandro. Bullying: como combatê-lo? Tradução de Eugênio Vinci de Moraes. São Paulo: Itália Nova, 2004.

CUBAS, Viviane. Bullying: assédio moral na escola. In: RUOTTI, Caren; ALVES, Renato; CUBAS, Viviane de Oliveira (Orgs.). Violência na escola: um guia para pais e 
professores. São Paulo: Andhep/Imprensa Oficial do Estado de São Paulo, 2006. p. 175-206.

Violência nas escolas: como defini-la? In: RUOTTI, Caren; ALVES, Renato; CUBAS, Viviane de Oliveira (Orgs.). Violência na escola: um guia para pais e professores. São Paulo: Andhep/Imprensa Oficial do Estado de São Paulo, 2006. p. 2352.

CURÇO, Sumaia Fuchs. Prática do bullying nas escolas. In: RODRIGUES, Carolina Cointreiras; AZEVEDO, José Clóvis de; POLIDORI, Marlis Morosini (Orgs.). Os desafios na escola: olhares diversos sobre questões cotidianas. Porto Alegre: Sulina/Universitária Metodista IPA, 2010. p. 87-101.

DAHRENDORF, Ralf. As classes e seus conflitos na sociedade industrial. Tradução de José Viegas. Brasília: Ed. UnB, 1982.

DAVID, Pedro R. Sociología criminal juvenil. 6. ed. Buenos Aires: Lexis Nexis, 2003.

DEBARBIEUX, Éric. Cientistas, políticos e violência: rumo a uma nova comunidade científica europeia para lidar com a violência nas escolas? In: DEBARBIEUX, Eric; BLAYA, Catherine (Orgs.). Violência nas escolas: dez abordagens europeias. Tradução de Patrícia Zimbres e Paula Zimbres Brasília. Unesco, 2002, p. 13-33.

. Violência nas escolas: divergências sobre palavras e um desafio político. In: DEBARBIEUX, Éric; BLAYA, Catherine (Orgs.). Violência nas escolas e políticas públicas. Tradução de Patrícia Zimbres. Brasília, Unesco, 2002. p. 59-92.

DEFRANCE, Bernard. La violence à l'école. 7. ed. Paris: La Découverte, 2009.

DEL PRIORE, Mary. O cotidiano da criança livre no Brasil entre a Colônia e o Império. In: DEL PRIORE, Mary (Org.). História das crianças no Brasil. São Paulo: Contexto, 2007. p. 84-106.

DEVINE, John. A mercantilização da violência escolar. In: DEBARBIEUX, Éric; BLAYA, Catherine (Orgs.). Violência nas escolas e políticas públicas. Tradução de Patrícia Zimbres. Brasília, Unesco, 2002. p. 207-223. . 
DIAS, Jorge de Figueiredo; ANDRADE, Manuel da Costa. Criminologia: o homem delinqüente e a sociedade criminógena. 2 reimp. Coimbra: Coimbra Ed., 1997.

DIÓGENES, Glória. Grupos identitários e fragmentação social: a violência como “marca”. In: SANTOS, José Vicente Tavares dos (Org.). Violência em tempo de globalização. São Paulo: Hucitec, 1999. p. 164-182.

DORNELLES, João Ricardo. Ofensiva neoliberal, globalização da violência e controle social. Discursos Sediciosos: crime, direito e sociedade, São Paulo, v. 7, n. 12, p. 119137, 2002.

DUBET, François. A formação dos indivíduos: a desinstitucionalização. Disponível em: <www.lcqribeiro.pro.br/wp-content/uploads/2011/03/A-forma\%C3\%A7\%C3\%A3odos-indiv\%C3\%ADduos-DubetFran\%C3\%A7ois.pdf>. Acesso em 10 jul. 2013.

As desigualdades multiplicadas. Tradução de Maria do Carmo Duffles Teixeira. Disponível em: <http://www.anped.org.br/rbe/rbedigital/rbde17/rbde17_03_francois_ dubet.pdf $>$. Acesso em 10 jul. 2013.

DUMOUCHEL, Paul. Ijime et La violence de l'indifférenciation dans le Japon moderne. In: MARTINEZ, Marie-Louise; SEKNAADJÉ-ASKÉNAZI, José (Orgs.). Violence et éducation: de la méconnaissance à l’action éclairée. 2. ed. Paris: L’Harmattan, 2002. p. 173-180.

DUPÂQUIER, Jacques. La violence en milieu scolaire. Paris: Presses Universitaires de France, 1999.

DURKHEIM, Émile. La división del trabajo social. Tradução de Carlos G. Posada. Madrid: Daniel Jorro, 1928.

ELIAS, Norbert. O processo civilizador. Tradução de Ruy Jungmann. Rio de janeiro: Zahar, 1993. v.1.

; SCOTSON, John L. Os estabelecidos e os outsiders: sociologia das relações de poder a partir de uma pequena comunidade. Tradução de Vera Ribeiro. Rio de Janeiro: Zahar, 2000. 
EINSTADTER, Werner J.; HENRY, Stuart. Criminological theory: an analysis of its underlying assumptions. 2. ed. Nova Iorque: Rowman \& Littlefield, 2006.

ENGUITA, Mariano Fernández. A face oculta da escola: educação e trabalho no capitalismo. Tradução de Tomaz Tadeu da Silva. Porto Alegre: Artes Médicas, 1989.

ENGELKE, Antonio. Quando os valores celebrados apontam no sentido de um individualismo extremado, então é certo que teremos um esgarçamento das relações sociais. Criança e consumo - entrevistas - violência. Projeto Criança e Consumo, Instituto Alana: coordenação editorial 2PRÓ Comunicação, 2011. p. 42-51 e 46.

FANTE, Cleo. Fenômeno bullying: como prevenir a violência nas escolas e educar para a paz. 2. ed. Campinas: Versus, 2005.

; PEDRA, José Augusto. Bullying escolar: perguntas e respostas. Porto Alegre: Artmed, 2008.

FERNÁNDEZ, Isabel. Prevenção da violência e solução de conflitos: o clima escolar como fator de qualidade. Tradução de Fulvio Lubisco. São Paulo: Madras, 2005.

FERREIRA, Pedro Moura. Vitimação juvenil. Lisboa: Centro de estudos judiciários, 1997.

FLORO, Michel. Questions de violence à l'école: pratiques du champ social. Saint-Agne: Erès, 1996.

FONSECA, Claudia. Quando cada caso NÃO é um caso. Revista Brasileira de Educação. n. 10, jan.-abr. 1999. p. 58-78.

FUNK. Walter. A violência nas escolas alemãs: situação atual. In: DEBARBIEUX, Eric; BLAYA, Catherine (Orgs.). Violência nas escolas: dez abordagens europeias. Tradução de Patrícia Zimbres e Paula Zimbres Brasília, Unesco, 2002, p. 131-152.

GABALDÓN, Luis Gerardo. Polícia, transgressión juvenil y control social informal. In: SERRANO MAÍLLO, Alfonso; GUZMÁN DÁLBORA, José Luis (Ed.). Procesos de infracción de normas y de reacción de normas: dos tradiciones criminológicas. Madrid: Dykinson, 2008. p. 55-67. 
GARCÍA MENDEZ, Emílio. Autoritarismo y control social: Argentina, Uruguay, Chile. Buenos Aires: Hammurabi, 1987.

GARCÍA-PABLOS DE MOLINA, Antonio. O que é Criminologia? Tradução de Danilo Cymrot. São Paulo: Revista dos Tribunais, 2013.

Tratado de Criminología. 2. ed. Valência: Tirant lo Blanch, 1999.

GARLAND, David. A cultura do controle: crime e ordem social na sociedade contemporânea. Tradução de André Nascimento. Rio de Janeiro: Revan, 2008.

GARRIDO, Vicente; STANGELAND, Per; REDONDO, Santiago. Principios de Criminología. 2. ed. Valência: Tirant lo Blanch, 2001.

GAUER, Ruth Maria Chittó. História de violência e desagregação: a igualdade imprime a desigualdade. In: WUNDERLICH, Alexandre (Coord.). Política criminal contemporânea: criminologia, direito penal e direito processual penal. Porto Alegre: Livraria do Advogado, 2008. p. 19-31.

GEERTZ, Clifford. La interpretación de las culturas. México: Gedisa, 1987.

GOFFMAN, Erving. Estigma: notas sobre a manipulação da identidade deteriorada. Tradução de Márcia Bandeira de Mello Leite Nunes. 4. ed. Rio de Janeiro: LCT, 1988. Manicômios, prisões e conventos. Tradução de Dante Moreira Leite. 7. ed. São Paulo: Perspectiva, 2005.

GOMES, Candido Alberto. A educação em novas perspectivas sociológicas. 4. ed. São Paulo: EPU, 2005.

GUARESCHI, Pedrinho A. O bullying está dentro da nossa sociedade, na própria família, que usa práticas pedagógicas verticais autoritárias. Criança e consumo - entrevistas violência. Projeto Criança e Consumo, Instituto Alana: coordenação editorial 2PRÓ Comunicação, 2011. p. 6-15.

et al. Bullying: mais sério do que se imagina. 2. ed. Porto Alegre: EDIPUCRS, 2008. 
GUTIÉRREZ, Carlos B. Tolerancia, despropósito conceptual en nuestros días. In: BORDA, Luis Villar; ROSALES, José María (Ed.). Las razones de la convivencia. Bogotá: Universidad Externado de Colombia, 2007. p. 85-105.

HAYDEN, Carol; BLAYA, Catherine. Comportamentos violentos e agressivos nas escolas inglesas. In: DEBARBIEUX, Eric; BLAYA, Catherine (Orgs.). Violência nas escolas: dez abordagens europeias. Tradução de Patrícia Zimbres e Paula Zimbres Brasília. Unesco, 2002. p. 63.102.

HIRSCHI, Travis. Causes of deliquency. New Brunswick: Londres: Transaction, 2001. . Una teoría del control de la delincuencia. Capítulo Criminológico, Maracaibo, v. 31, n. 4, p. 5-31, out.-dez. 2003.

HIRST, Paul Q. Marx y Engels sobre la ley, el delito y la moralidad. Tradução de Nicolas Grab. In: TAYLOR, Ian; WALTON, Paul; YOUNG, Jock (Dirs.). Criminología crítica. Cerro del Agua, Madri/Bogotá: Siglo Veintiuno, 1977. p. 255-287.

HULSMAN, Louk; CELIS, Jacqueline Bernat de. Penas perdidas: o sistema penal em questão. Tradução de Maria Lúcia Karan. Rio de Janeiro: Luam, 1993.

ILLICH, Ivan. Sociedade sem escolas. 4. ed. Tradução de Lúcia Mathilde Endlich Orth. Petrópolis: Vozes, 1973.

INSTITUTO BRASILEIRO DE GEOGRAFIA E ESTETÍSTICA. Disponível em: $<$ http://www.ibge.gov.br/home/estatistica/populacao/trabalhoerendimento/pnad2011/br asil_defaultpdf_trabalho.shtm>. Acesso em 8 nov. 2013.

INSTITUTO SOU DA PAZ. Grêmio em forma: o fomento à participação dos jovens na escola como estratégia de prevenção de violência. In: WESTPHAL, Márcia Faria; BYDLOWSKI, Cynthia Rachid (Eds.). Violência e juventude. São Paulo: Hucitec, 2010. p. 281-288.

KAHN, Túlio. Efeitos das mudanças no sistema escolar sobre a violência. Revista do ILANUD, São Paulo, n. 23, 79-105, 2002.

KAISER, Günter. Introducción a la Criminología. 7. ed. Tradução de José Arturo Rodríguez Núñez. Madrid: Dykinson, 1988. 
KARSTEDT, Susanne. Democracia, valores e violencia: paradojas, tensiones y ventajas comparativas de la inclusión liberal. In: SERRANO MAÍLLO, Alfonso; GUZMÁN DÁlBORA, José Luis (Eds.). Procesos de infracción de normas y de reacción de normas: dos tradiciones criminológicas. Madrid: Dykinson, 2008. p. 277-312.

KLOSINSKI, Gunther. Adolescência hoje: situações, conflitos e desafios. Tradução de Carlos Almeida Pereira. Petrópolis: Vozes, 2006.

KOEHLER, Sônia Maria Ferreira. As faces do bullying: implicações sociais e emocionais a partir das relações interpessoais no ambiente escolar. In: ALKIMIN, Maria Aparecida (Org.). Bullying: visão interdisciplinar. Campinas: Alínea, 2011. p. 33-51.

KRUPPA, Sonia M. Portella. Sociologia da educação. São Paulo: Cortez, 1994.

LA TALLE, Yves. Glória e violência: reflexão sobre a influência da televisão na construção da personalidade moral. In: PACHECO, Elza Dias (Org.). O cotidiano infantil violento: marginalidade e exclusão social. São Paulo: Lapic: L’Editora: Fapesp, 2007. p. 153-163.

LARRAURI, Elena. La herencia de la criminología crítica. 2. ed. Madrid: Siglo Veintiuno, 2000.

LATERMAN, Ilana. Violência e incivilidade na escola: nem vítimas, nem culpados. Florianópolis: Letras Contemporâneas, 2000.

LEA, John; YOUNG, Jock. Qué hacer com la ley y el orden? Tradução de Martha B. Gil e Mariano A. Ciafardini. Buenos Aires: Editores Del Puerto, 2001.

LEITE, Miriam Soares. Violência e homofobia na escola. In: CANDAU, Vera Maria (Org.). Didática crítica intercultural: aproximações. Petrópolis: Vozes, 2012. p. 191215.

LEISTER, Margareth Anne; TREVISAN, Elisaide. A tolerância e os direitos humanos: aceitar o multiculturalismo e as diversidades para viver uma cultura democrática. Revista Mestrado em Direito, Osasco, v. 12, n. 1, p. 199-227, jan.-jul. 2012. 
LEME, Maria Isabel da Silva. Educação, diversidade e igualdade: violência e convívio escolar. In: CARDOSO, Clodoaldo Meneguello (Org.). Convivência na diversidade: cultura, educação e mídia. Bauru: Unesp; FAAC, 2008. p. 107-126.

LENHARD, Rudolf. Sociologia educacional. São Paulo: Livraria Pioneira, 1973.

LEVINAS, Emmanuel. Le temps et l'autre. 9. ed. Paris: Quadrige, 2007.

LOCKE, John. Carta sobre a tolerância. Tradução de Ari Ricardo Tank Brito. São Paulo: Hedra, 2007.

LUCINDA, Maria da Consolação; NASCIMENTO, Maria das Graças; CANDAU, Vera Maria. Escola e violência. 2. ed. Rio de Janeiro: DP\&A, 2001.

LUNARDI- LAZZARIN, Márcia Lise. Os discursos da diferença no contexto das políticas de inclusão: a anormalidade no detalhe. In: TREVISAN, Amarildo Luiz; TOMAZETTI, Elisete Medianeira; ROSSATTO, Noeli Dutra (Orgs.). Diferença, cultura e educação. Porto Alegre: Sulina, 2010. p. 142-152.

MARCUSE, Herbert. Tolerância repressiva. In: WOLFF, Robert Paul; JUNIOR, Barrington Moore; MARCUSE, Herbert. Crítica da tolerância pura. Tradução de Ruy Jungmann. Rio de Janeiro: Zahar, 1970. p. 87-126.

MAREUSE, Márcia Aparecida Giuzi. Reflexões sobre a violência: manifestações na mídia e implicações no universo infantojuvenil. In: PACHECO, Elza Dias (Org.). O cotidiano infantil violento: marginalidade e exclusão social. São Paulo: Lapic: L’Editora: Fapesp, 2007. p. 41-51.

MARTÍN RÍOS, Maria Del Pilar. Aspectos procesales del tratamiento en España del bullying o acoso escolar. Revista de Derecho e Proceso Penal, Navarra, n. 29, p. 13-23, set.-dez. 2012.

MARTINEZ, Marie-Louise. Comprendre la violence une et multiforme. In: MARTINEZ, Marie-Louise; SEKNAADJÉ-ASKÉNAZI, José (Orgs.). Violence et éducation: de La méconnaissance à l’action éclairée. 2. ed. Paris: L’Harmattan, 2002. p. 5-19.

MELOSSI, Dario; PAVARINI, Massimo. Cárcere e fábrica: as origens do sistema penitenciário. Tradução de Sérgio Lamarão. Rio de Janeiro: Revan, 2006. 
MENDES, Marcos Baptista. A violência: reflexões teóricas e o processo de mudança nas instituições policiais. In: LINARDI, Carlos José; MIRANDA, Orlando de (Eds.). Violência \& Sociedade. São Paulo: Letras e Letras, 2003. p. 89-113.

MERTON, Robert K. Sociologia: teoria e estrutura. São Paulo: Mestre Jou, 1970.

MICHAUD, Yves. A violência. Tradução de L. Garcia. São Paulo: Ática, 1989.

MIDDELTON-MOZ, Jane; ZAWADSKI, Mary Lee. Bullying: estratégias de sobrevivência para adultos e crianças. Tradução de Roberto Cataldo Costa. Porto Alegre: Artmed, 2007.

MIRAGLIA, Paula. “A sociedade está anestesiada em relação à vitimização da juventude”. Criança e consumo - entrevistas - violência. Projeto Criança e Consumo, Instituto Alana: coordenação editorial 2PRÓ Comunicação, 2011. p. 53-63.

MIRALLES, Teresa. El control informal. In: BERGALLI, Roberto; BUSTOS RAMÍREZ ,Juan (Dirs.). El pensamiento criminológico: Estado y control. Bogotá: Temis, 1983. p. 37-62. v. 2.

MORAIS, Regis de. Violência e educação. Campinas: Papirus, 1995. (Coleção Magistério: Formação e trabalho pedagógico).

MORITA, Yohji. Violência na escola: uma abordagem japonesa. In: DEBARBIEUX, Éric; BLAYA, Catherine (Orgs.). Violência nas escolas e políticas públicas. Tradução de Patrícia Zimbres. Brasília, Unesco, 2002. p. 93-136.

NASCIMENTO, Grasiele Augusta Ferreira. Bullying: a violência no âmbito escolar. In: ALKIMIN, Maria Aparecida (Org.). Bullying: visão interdisciplinar. Campinas: Alínea, 2011. p. 13-31.

NOGUEIRA, Rosana Maria César Del Picchia de Araújo. Violências nas escolas e juventude: um estudo sobre bullying escolar. 2007. 257f. Tese (Doutorado em Educação) - Faculdade de Educação - Pontifícia Universidade Católica de São Paulo, [2007]. 
NOVINSKY, Anita Waingort. Para um novo conceito de educação. In: CARDOSO, Clodoaldo Meneguello (Org.). Convivência na diversidade: cultura, educação e mídia. Bauru: Unesp; FAAC, 2008. p. 77-88.

OBSERVATÓRIO DA INFÂNCIA. Diga não para o bullying. Disponível em: <www.observatoriodainfancia.com.br/IMG/pdf/doc-100.pdf>. Acesso em 2 jul. 2012.

OLIVEIRA, Salete. Tolerar, julgar, abolir. In: PASSETTI, Edson; OLIVEIRA, Salete (Orgs.). A intolerância e o intempestivo. Cotia: Ateliê Editorial, 2005. p. 191-201.

OLWEUS, Dan. Bullying at school. Oxford; Cambridge: Blackwell, 1993.

Bullying at school: long-term outcomes for the victims an effective school-based intervention program. In: HUESMANN, L. Rowel (Ed.). Aggressive behavior: current perspectives. Nova Iorque: Plenum, 1994. p. 97-130.

ORTEGA, Rosario. O projeto de Sevilha contra a violência nas escolas: um modelo de intervenção educacional de natureza ecológica. In: DEBARBIEUX, Eric; BLAYA, Catherine (Orgs.). Violência nas escolas: dez abordagens europeias. Tradução de Patrícia Zimbres e Paula Zimbres Brasília. Unesco, 2002. p. 197-222.

PAIVA, Vanilda. Violência e pobreza: a educação dos pobres. In: ZALUAR, Alba (Org.). Violência e educação. São Paulo: Cortez, 1992. p. 65-101.

PAREDES, Eugênia Coelho; SAUL, LÉA Lima; BIANCHI, Kátia Simone da Rosa. Violência: o que têm a dizer alunos e professores da rede pública de ensino cuiabana. Cuiabá: EdUFMT; Fapemat, 2006. (Coleção Educação e psicologia, v. 2).

PARSONS, Talcott. Uma visão geral. Tradução de Octavio Mendes Cajado. In: PARSONS, Talcott (Org.). A sociologia americana. São Paulo: Cultrix, 1970. p. 366383.

PASSETTI, Edson. Crianças carentes e políticas públicas. In: DEL PRIORE, Mary (Org.). História das crianças no Brasil. São Paulo: Contexto, 2007. p. 347-375.

PAULA, Carlos Alberto de. A violência na escola. In: Secretaria de Estado da Educação. Superintendência da Educação. Curitiba: Diretoria de Políticas e Programas 
Educacionais. Coordenação de Desafios Educacionais Contemporâneos (SEED), 2008. p. 21-28.

PAVARINI, Massimo ¿A donde vamos? Capítulo Criminológico, Maracaibo, n. 22, p. 318, 1994.

Como resistir: control social y saber critico. Capítulo Criminológico, Maracaibo, n. 22, p. 33-53, 1994.

PERALVA, Angelina. Violência e democracia: o paradoxo brasileiro. São Paulo: Paz e Terra, 2000.

PEREIRA, Beatriz Oliveira. Para uma escola sem violência: estudo e prevenção das práticas agressivas entre crianças. 2. ed. Lisboa: Fundação Calouste Gulbenkian/Fundação para a Ciência e a Tecnologia, 2008.

PESSOA, Ana Maria. Razões e emoções silenciadas das representações da violência e juventude no espaço público. In: ALVIM, Rosilene et al. (Org.). Jovens e juventudes. João Pessoa: Universitária, 2005. p. 199-212.

PIERUCCI, Antônio Flávio. Problemas com a igualdade (ou: ciladas da diferença). Cadernos de Sociologia, Porto Alegre, n. especial, p. 149-158, 1995.

PINTO, Celi Regina Jardim. Para além da tolerância. In: BIASOLI-ALVES, Zélia Maria Mendes; FISCHMANN, Roseli (Orgs.). Crianças e adolescentes: construindo uma cultura da tolerância. São Paulo: Edusp, 2001. p. 43-61.

PIPHER, Mary Bray. O resgate de Ofélia: o drama da adolescente no mundo moderno. Tradução de Wáldea Barcellos. São Paulo: Martins Fontes, 1998.

PUPO, Kátia Regina. Violência moral no interior da escola: um estudo exploratório das representações do fenômeno sob a perspectiva de gênero. 2007. 228f. Dissertação (Mestrado em Educação) - Faculdade de Educação - Universidade de São Paulo, [2007].

RAMOS, Adriana de Melo; ARAGÃO, Ana Maria Falcão de; VINHA, Telma Pillegi. O adolescente, a violência e os conflitos na escola: como construir um ambiente sociomoral cooperativo? In: VALLE, Luíza Elena L. Ribeiro do; MATTOS, Maria José 
Viana Marinho de (Orgs.). Adolescência: as contradições da idade. 2. ed. Rio de Janeiro: Wak, 2010. p. 125-148.

RAYO, José Tuvilla. Educação em direitos humanos: rumo a uma perspectiva global. Tradução de Jussara Haubert Rodrigues. 2. ed. Porto Alegre: Artmed, 2004.

REPA, Luiz. Reconhecimento da diferença na teoria crítica. In: TREVISAN, Amarildo Luiz; TOMAZETTI, Elisete Medianeira; ROSSATTO, Noeli Dutra (Orgs.). Diferença, cultura e educação. Porto Alegre: Sulina, 2010. p. 17-34.

RIBEIRO, Luciana. Ser preto, pobre e ladrão: dramaturgia e estigmaticação à luz de Goffman. In: ALVIM, Rosilene et al. (Org.). Jovens e juventudes. João Pessoa: Universitária, 2005. p. 239-246.

RUOTTI, Caren. Exposição à violência escolar e percepções sobre suas causas. In: RUOTTI, Caren; ALVES, Renato; CUBAS, Viviane de Oliveira (Orgs.). Violência na escola: um guia para pais e professores. São Paulo: Andhep/Imprensa Oficial do Estado de São Paulo, 2006. p. 153-172.

RUIZ, Rosário Ortega. Violência, agressão e disciplina. In: FERNÁNDEZ, Isabel. Prevenção da violência e solução de conflitos: o clima escolar como fator de qualidade. Tradução de Fulvio Lubisco. São Paulo: Madras, 2005. p. 23-32.

RUSCHE, Georg; KIRCHHEIMER, Otto. Punição e estrutura social. Tradução de Gizlene Neder. 2. ed. Rio de Janeiro: Revan, 2004.

SAITO, Marta Ignez. Violência interpessoal na adolescência. In: WESTPHAL, Márcia Faria; BYDLOWSKI, Cynthia Rachid (Eds.). Violência e juventude. São Paulo: Hucitec, 2010. p. 151-161.

SALLA, Fernando; MALVASI, Paulo. Homicídios de adolescentes nas cidades da faixa de fronteira do Brasil: reflexões em torno da questão da vulnerabilidade. Revista Brasileira de Ciências Criminais, São Paulo, v. 104, n. 21, p. 260-277, set.-out. 2013.

SANTOS, Juarez Cirino. A criminologia radical. Rio de janeiro: Forense, 1981.

SCHILLING, Flávia. Violência na escola. In: WESTPHAL, Márcia Faria; BYDLOWSKI, Cynthia Rachid (Eds.). Violência e juventude. São Paulo: Hucitec, 2010. p. 219-232. 
SHARIFF, Shaheen. Ciberbullying: questões e soluções para a escola, a sala de aula e a família. Tradução de Joice Elias Costa. Porto Alegre: Artmed, 2011.

SHAW, Clifford R; MCKAY, Henry D. Juvenile Deliquency and urban areas. Chicago: University of Chicago, 1942.

SHECAIRA, Sérgio Salomão. Criminologia. 4. ed. São Paulo: Revista dos Tribunais, 2012.

Sistema de garantias e o direito penal juvenil. São Paulo: Revista dos Tribunais, 2008.

SICA, Ana Paula Zomer. Prevenção criminal: análise de políticas extrapenais. Rio de Janeiro: Lumen Juris, 2009.

SILVA, Clemildo Anacleto da. Educação, tolerância e direitos humanos: a importância do ensino de valores na escola. Porto Alegre: Sulina/Universitária Metodista, 2009.

SILVA, Nelson Pedro. Ética, indisciplina e violência nas escolas. 2. ed. Rio de Janeiro: Vozes, 2004.

SIMMONS, Rachel. Garota fora do jogo: a cultura oculta da agressão nas meninas. Tradução de Talita M. Rodrigues. Rio de Janeiro: Rocco, 2004.

SMITH, Peter K. Intimidação por colegas e maneiras de evitá-la. In: DEBARBIEUX, Éric; BLAYA, Catherine (Orgs.). Violência nas escolas e políticas públicas. Tradução de Patrícia Zimbres. Brasília, Unesco, 2002. p. 187-205.

; SHARP, Sônia. The problem of school bullying. In: SMITH, Peter K.; SHARP, Sônia (Eds.). School bullying: insights and perspectives. Londes; Nova Iorque: Routkedge, 1994. p. 1-19.

SPOSITO, Marilia Pontes. Algumas reflexões e muitas indagações sobre as relações entre juventude e escola no Brasil. In: ABRAMO, Helena Wendel; BRANCO, Pedro Paulo Martoni (Orgs). Retratos da juventude brasileira: análises de uma pesquisa nacional. São Paulo: Perseu Abramo, 2005. p. 87-127. 
A redução da violência escolar como desafio democrático. Revista do ILANUD, São Paulo, n. 23, 107-117, 2002.

As vicissitudes das políticas públicas de redução da violência escolar. In: WESTPHAL, Márcia Faria (Org.). Violência e criança. São Paulo: Universidade de São Paulo, 2002. p. 249-265.

. Violência e escola: as múltiplas faces de uma relação. In: PACHECO, Elza Dias (Org.). O cotidiano infantil violento: marginalidade e exclusão social. São Paulo: Lapic: L’Editora: Fapesp, 2007. p. 53-65.

SUTHERLAND, Edwin H. Princípios de criminologia. Tradução de Asdrúbal Mendes Gonçalves. São Paulo: Livraria Martins, 1949.

SUXBERGER, Antonio Henrique Graciano. A inserção do controle social nas escolas criminológicas: do monismo social à criminologia crítica. Ciências Penais: Revista da Associação Brasileira de Professores de Ciências Penais, São Paulo, v. 3, n. 5, p. 214230, jul.-dez. 2006.

TAVARES, Juarez. A racionalidade, o direito penal e o poder de punir: os limites da intervenção penal no Estado Democrático. In: ZILIO, Jacson; BOZZA, Fábio. Estudos críticos sobre o sistema penal: homenagem ao professor Doutor Juarez Cirino dos

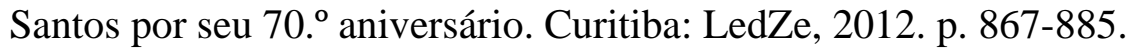

TENGARRINHA, José. Tolerância e convivialidade pública e privada. In: BIASOLIALVES, Zélia Maria Mendes; FISCHMANN, Roseli (Orgs.). Crianças e adolescentes: construindo uma cultura da tolerância. São Paulo: Edusp, 2001. p. 35-41.

TOGNETTA, Luciene Regina Paulino; VINHA, Telma Pileggi. Estamos em conflito: eu, comigo e com você! Uma reflexão sobre o bullying e suas causas afetivas. In: CUNHA, Jorge Luiz da; DANI, Lúcia Salete Celich (Org.). Escola, conflitos e violências. Santa Maria: UFSM, 2008. p. 199-246.

TOGNOLLI, Cláudio Júlio. Nazismo redivivo: a imprensa também matou em Taiúva. Disponível em: <www.observatoriodaimprensa.com.br/artigos/jd120220031.htm>. Acesso em: 4 jul. 2012. 
URIARTE, Carlos Elías. Control institucional de la niñez adolescencia en infracción: un programa mínimo de contención y límites jurídicos al Sistema Penal Juvenil (las penas de lós jóvenes). Montevidéu: Carlos Alvarez, 1999.

VAN SWAANINGEN, René. Perspectivas europeas para uma Criminología crítica. Tradução de Silvia Susana Fernandez. Buenos Aires: BDEF, 2011.

VIEIRA, Oscar Vilhena. Los límites de la autoridade del derecho. In: VALDEZ, Antonio Garzón et al. (Orgs.). Violencia y derecho. Buenos Aires: Editores Del Puerto, 2004. p. 321-334.

VISCARDI, Nilia. Disciplinamiento, control social y estigma: tres conceptos para una sociología del conflito: el caso de la violencia en el espacio escolar en Uruguay. Sociologias, Porto Alegre, v. 1, n. 1, p. 168-198, 1999.

VOLTAIRE. Tratado sobre a intolerância: a propósito da morte de Jean Calas. Tradução de Paulo Neves. 2. ed. São Paulo: Martins Fontes, 2000.

WACQUANT, Loïc. A globalização da tolerância zero. Discursos Sediciosos, Rio de Janeiro, v. 5, n. 9/10, p. 111-119, 2000.

WAISELFISZ, Julio Jacob; MACIEL, Maria. Revertendo violências, semeando futuros: avaliação de impacto do programa abrindo espaços no Rio de Janeiro e em Pernambuco. 3. ed. Brasília, Unesco, 2003.

YOUNG, Jock. A sociedade excludente: exclusão social, criminalidade e diferença na modernidade recente. Tradução de Renato Aguiar. Rio de Janeiro: Revan, 2002.

ZAFFARONI, Eugenio Raúl. Criminología: aproximación desde un margen. Colômbia: Temis, 1993.

; PIERANGELI, José Henrique. Manual de direito penal brasileiro: parte geral. 8. ed. São Paulo: Revista dos Tribunais, 2010.

ZONTA, Celso. Igualdade/desigualdade: significações e sentidos no contexto da Psicologia. In: CARDOSO, Clodoaldo Meneguello (Org.). Convivência na diversidade: cultura, educação e mídia. Bauru: Unesp; FAAC, 2008. p. 29-40. 